\title{
BIRDS OF
}

\section{NEW HAMPSHIRE}

\author{
ALLEN
}




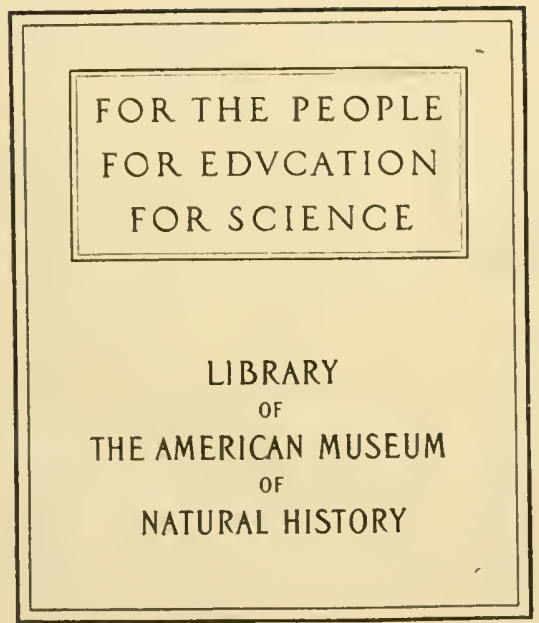








\title{
A LIST OF T'HE BIRDS \\ $\mathrm{OF}$ \\ NEW HAMPSHIRE.
}

\author{
BY
}

Glover M. Allen.

Frum the Pruceedings of the Manchester Institute of Arts and Sciences,

I미, II, 1902,

MANCHESTER, N. H.

NATURF STUDY PRESS.

1903. 


$$
\begin{aligned}
& \text { Q } \\
& \text { thmen ing if no }
\end{aligned}
$$

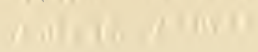

$$
c \text { scos s.t. }
$$




\section{CONTENTS.}

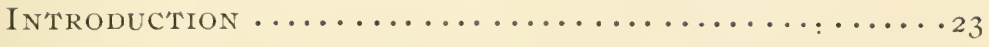

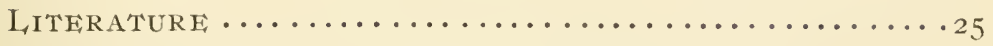

Time Faunat, Areias of New Hampshire............ 36

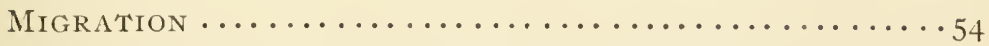

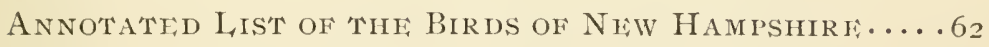

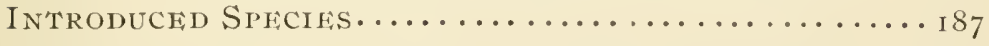

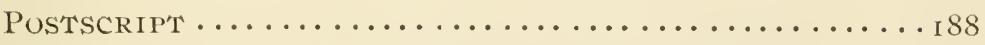
RFFERENCES TO LITERATURE ................. . 94

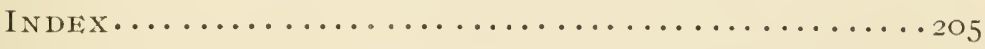





\section{THE BIRDS}

$\mathrm{OF}^{*}$

\section{NEW HAMPSHIRE.}

BY GLOVER MORRILL ALLEN.

\section{INTRODUC'TION.}

In the following pages an attempt has been made to bring together a list of the species of birds known to have occurred within the State of New Hampshire during historic times, together with a general account of their distribution, fannal position, times of migration, and, in case of the rarer species, a detailed list of the known instance of occurrence. The present list can be at best only preliminary, and there remains much yet to be done in the way of obtaining more complete information as to the details of distribution and migration, and particularly so in the case of the water birds.

In addition to much that has been already recorded in many books and periodicals, a considerable body of unpublished facts relative to the birds of the State is here included, based not only on the writer's personal observations, but also on those of a $111 \mathrm{~m}$ ber of ornithologists who have contributed most generously of their notes, and to whom due ackinowledgment is made.

The sequence of names and their spelling are strictly those of the American Ornithologists' Union, instead of those used by Mr. R. H. Howe, Jr., and myself in the "Birds of Massachusetts, " since it is believed that the use of the order more commonly adopted will make the list more convenient as a working basis for more complete catalogues. The distribution of the breeding 
birds of the State is given so far as possible, faunally, the limits of the faunal areas being elsewhere defined. Extralinital migration dates are given in parentheses. Care has been taken to exclude from the list all doubtful records, or those resting on an unsubstantial basis, hence the frequency of the words "taken" or "captured" in connecion with many of the records. A recent writer has deplored the killing of rare or uncommon birds in order to establish positively a "record" and, indeed, it is to be regretted that swch a necessity exists. Accuracy, however, demands that the young ornithologist or the beginner shall substantiate in some acceptable way his often hasty identification based on a passing glimpse of a bird with which he is perhaps quite unfamiliar. To merely record one's belief that a certain rare species was observed is in most cases of no value whatsoever and should be more carefully guarded against than is at present done. The trained naturalist, who appreciates at what pains facts are determined, is content to leave unrecorded that of which he is in doubt. Of much greater value is it to establish one new fact in the life history of a common bird, than to record the accidental presence of a species far from its normal range.

It remains to express my thanks to all who have contributed to the present undertaking, and especially to Mr. William Brewster of Cambridge, Mass., who has generously contributed a number of observations on water birds; Dr. Walter Faxon of Cambridge, Mass.; Mr. W. E. Cram of Hampton Falls; Mr. G. H. Thayer of Monadnock; Mr. C. F. Goodhue of Webster; Mr. V. D. Lowe of Randolph; Mr. W. M. Buswell of Charlestown; Dr. W. H. Fox of Washington, D.C.; Mr.F. H. Allen of WVest Roxbury, Mass.; Mr. Ralph Hoffmann of Belmont, Mass.; Mr. R. H. Howe, Jr., of Brookline, Mass.; Mr. H. W. Wright of Boston, Mass., for their gencrosity in supplying many valuable notes from their observations in varions parts of New Hampshire. 


\section{LITERATURE.}

The first printed reference to any New Hampshire bird appears to be that of John Josselyn, in I672, in his "New England's Rarities Discovered In Birds, Beasts, Fishes, Serpents, and Plants of that Country." He describes "the pilhannaw, or mechquan, much like the description of the Indian ruck; a monstrous great bird; a kind of hawk, - some say an eagle; four times as big as a goshawk; white-mailed, having two or three purple feathers in her head, as long as geese's feathers they make pens of. 'The quills of these feathers are purple, as big as swan's quills, and transparent. Her head is as big as a child's of a year old; a very princely bird. When she soars abroad, all sort of feathered creatures hide themselves; yet she never preys upon any of them, but upon fawns and jaccals. She ayries in the woods upon the high hills of Ossapy, and is very rarely or seldom seen. " It is generally supposed that this " princely bird, " whose home was among the Ossipee hills, or higher peaks beyond, must have been largely fabulous. Doubtless, as suggested by Dr. Tuckerman, Josselyn's bird was but a confused conception of the golden eagle, the bald eagle, and the great blue heron. The purple feathers are supposed to indicate the heron, and the white head and tail of the bald eagle may meet the conception of a "whitemailed" bird; the habit of preying upon fawns perlaps indicates the golden eagle.

After this brief mention, I have found no further reference to the birds of New Hampshire until I792, over one luundred years later. In this year appeared Jeremy Belknap's "History of New Hampshire," in the third volume of which is given an account of the natural products of that portion of New England. 
Here is given the first list of New Hampshire birds that has appeared in print. One hundred and twenty-two species are listed by their English and Latin names as then used, and eight other names are included among the addenda, on the authority of one Mr. Peck. Considering that this list was prepared long before the days of the "A. O. U., " when there were no popular handbooks nor guides beyond Linnæus' Systema Naturæ, one cannot but be impressed by the care and accuracy shown by the compiler, here as elsewhere in the volume. Of these one hundred and thirty names, probably at least five are but repetitions, and of the rest, there are but seven or eight whose identity may not be guessed at with more or less confidence. Belknap considered no less than four of the species he listed, to be new to science, and these he distinguished by new specific names in a style of type different from that used for the specific names of the other species. These four "new" birds were:- "SPECKIED WOODPECKER, Picus maculosus," "LARGE SPOTTED Plover, Charadrius maculatus," "WINTHR SPARrow, Fringilla grisea," and "Brown F I yCATCHER, Muscicapa fusca."

It is of course impossible now to determine in how far Belknap's identifications were correct, and one may reasonably question the occurrence in New Hampshire, even in those days. of such birds as the "Carolina Woodpecker, Picus carolinus," and the "Crested Titmouse, Parus bicolor." It must be borne in mind, however, that great changes in the ranges and relative abundance of many birds must have taken plaçe since Belknap's day. No other State list of New Hampshire birds has since been published, and because of its nulusual interest as a scrap of early literature on the subject, it is reprinted herewith, verbatim et litcratim, the probable identity of each name being indicated by the Latin combination in brackets following :-

"Of BIRDS we liave a great variety. The following catalogue is the most full, which has been collected, but cannot boast of perfection.

BAI,I E EAGLE,

Falco leucocephalus [Maliaetus leucocephalus]. 
BROWN EAGI,F,

IARGE BROWN HAWK,

HEN HAWK,

PIGFOON HAKK,

WHITE OWI,

SPIECKLED OWL,

BAKN OWI,

BIRD HAWKK,

KING BIRD,

CROW

Br,UE: JAY,

HANG BIRD,

RED-IVINGED BIACK BIRD,

GOLDEN ROBIN OR GOLD FINCH,

CROW BrACK BIRD,

Cuckow,

GREAT REI CRESTED WOODPFCKFR, Picus pileatus [Ceophloens pileatus abieticola].

SWALIOW WTOODPECKER,

RED HEAI WOODPECKER,

WHITE BACK WOODPECKER,

CAROLINA WOODPECKER,

WOOLY BACK WOODPECKIE,

WHITE TAIL, WOODPECKER,

SPECKLED WOODPECKER,

NUT HATCH,

KINGFISHER,

CREFPER,

HuMMing BIRD,

SWAN,

The SWAN is the largest of the aquatic tribe which is seen in this country. One of them has been known to weigh $36 \mathrm{lb}$. and to be six feet in length from the bill to the feet, when stretched. Naturalists have different opinions respecting the music of the swan. The tame swan of England is said to be silent; and Dr. Goldsmith seems to think the accounts of the music of the wild swan fabulous. What is deemed fabulous in Europe, is often 
realized in America. It is certain that our swan is heard to make a sound resembling that of a trumpet, both when in water and on the wing.

WHITE HEAD COOT,

BROW: COOT,

BLACK DUCK,

WhITE, GOOSF,

BLUISH GoOSE,

BRANT Or BRENT,

IVII,D OR BIACK GOOSE,
Anas spectabilis [Oidemia perspicillata].

Anas fusca [Oidemia sp. female?].

Anas nigra [Anas obscura?].

Anas erythropus [Chen hyperborea].

Anas cærulescens [Chen carulescens].

Anas bernicla [Branta bernicla].

Anas canadensis [Branta canadensis].

'This is the bird which Dr. Hild calls the Swan goose. It is a bird of passage, and gregarious; the form of the phalanx, when on the wing, is that of a wedge. By the mixture of this with the common goose, a mongrel breed is produced, which is more valuable than either of them singly. 'The wild goose, though it migrates from one part of the continent to the other, yet has its local attachments. One of them, which was caught in the spring, and kept in a farm yard with a flock of domestic geese, when the time of its migration arrived, took the first opportunity to join a flock in their passage to the southward; but at the return of spring, came back and alighted in the same yard with four young ones, which she had produced in her absence.

The BRANT is rare in New-Hampshire; but in the bay of Massachusetts, is found in great abundance.

SF.A DLCK,

DIPPER,

OI,INIFE,

QUINDAR,

WHISTI,ER,

WIIJGEN,

MAI,IARI, or SPRIS;- ?

TAIIFD DUCK,

I OKD and IANY, or ,

Sisa PIGEON,

BI, W: WINGED TEA,

GRHEN WINGID THAI,

GRl:Y WUOD DUCK,

IYOOI) DuCK,
Anas mollissima [Somateria dresseri].

Anas albeola [Charitonetta albeola].

Anas strepera? [Harelda hyemalis ].

Anas bucephala? [Clangula clangula anericana].

Anas clangula? [Clangula clangula americana].

Anas penelope? [Mareca americana].

Anas acuta [Dafila acuta?].

Anas histrionica? [Histrionicus listrionicus ].

Anas discors [Querquedula discors].

Anas - [Nettion carolinensis].

Anas sponsa [Aix sponsa].

Anas arborea [ $\mathrm{Aix}$ sponsa]. 
CRFAM COLOURED )

SHELIDRAKE， ,

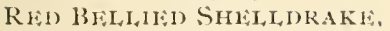

PYFD SHI:I,1,DRAKF,

PISNGLIN,

WATER HIS, OF WATER WITCH, P'ELICAN,
Mergus merganser? [Merganser allericallus ]

Mergus serrator? [Merganser serrator].

Mergus castor? [ I opliodytes cucullatus].

Alca impennis [Plautus impenuis]. Alca artica? [Colymbus or ["riasp.]. I'elicanus onocrotalus occidentalis [Pelecaniss erytlirorliyinchos].

The Pelican migrates from its native conntry, the Missisippi [sic], far to the northward. It has been seen in New-Hampshire. The Anerican Pelican is not a distinct species from the Pelican of Asia and Africa but, a variety only.

ShaG,

GANNF'T,

LOON,

WHITE GULL,

GREY GUI,

MACKEREI, GULI,

TEF-ARR, or FISHING GULI,

Crane,

STORK,

BLUE HERON,

SKOUK,

WHITF: HERON,

WOODCOCK,

WOOD SNIPE,

GREY CURI,EW,

LARGE SPECKLED ?

CURIEW

HUMUI'TY,

MARSH BIRD,

ROCK B1RD,

OX-EYE,

BEACH BIRD,

BhaCK BREASTED PLOVER,

KILDEE,
Pelecanus graculus? [Phalacrocorax sp.].

P'elecanus cassanus? [Sula bassana].

Colymbus inmer [Gavia imber].

Larus canus [Larus argentatus].

Larus fuscus? [Larus argentatus juv.].

Larus ridibundus [Sterna hirundo? ].

Sterna minuta [Sterna antillaruil1?].

Ardea canadensis [Grus mexicana].

Ardea ciconia [Nycticorax nycticorax nevius].

Ardea cærulea [Ardea herodias].

Ardea virescens [Ardea virescens].

Ardea alba [Ardea egretta?].

Scolopax rustica [Philohela miiior ].

Scolopax fedoa [Helodromas solitarins?].

Scolopax totanus [Numeuius borealis?].

Scolopax lapponica [Numenius hudsonicus].

Tringa interpres? [?].

Tringa morinella? ['Tringa maculata?].

Tringa maculata [Actitis macularia].

'Tringafulicaria? [Erennetes pusillus?].

Tringa arenaria [Calidris arenaria].

Charadrius hiaticula [Squatarola squatarola].

Charadrius rociferus? [Egialitis vocifera]. 
PYin P'LOYT:R,

LARGE SPOTTED PLONER, PEEP,

WLLD TURKLV,
Characlrius apricarius [Egialitis semipalmata?].

Charadrius maculatus [?].

Rallus carolinus [Porzana carolina?].

Meleagris gallopavo [Meleagris gallopavo fera].

WILD TURKIES were formerly very numerous. In winter they frequented the sea shore, for the saks: of picking small fishes and marine insects, which the tide leaves on the flats. Jossely'n, who resided eight years in the Province of Maine, and wrote in 1672 , says, that he had eaten part of one, which, when prepared for the spit, weighed thirty pounds, and Wood, who risited the country earlier, and wrote in 1639 , speaks of some which weighed forty pounds. They are now retired to the inland mountainous country. Dr. Goldsmith doubts whether any of this breed have been tamed in Anerica. 'They certainly have been tamed; but they are degenerated in size by their donestication, scarcely any being more than half so heary as those above mentioned. The turkey is a rambling bird, and runs with great speed on the ground. The tame flocks trequently wander, and cannot be fatted till the snow prevents their excursions.

GROWSE,

Tetrao-[Canachites canadensis canace $]$.

The GROwsE is rarely seen, as there are no dry heaths in New-Hampshire, but on the tops of the largest mountains, which are seldon visited by man. This bird has a red head, is larger than the partridge, and its flesh, though red and dry, has a high flavour, and is very tender.

Quist,

PARTRIDGF,

Tetrato virginiauus [Colinus virginianus ].

Tetrao marilandicus [Bonasa umbellus togata].

'T'he PAR'TRIDGL is very common in our woods. Some of our epicurean genlry have begun to fear, that its race will be too soon extinct; but there is no danger. This bird is very prolific ; it is common to find twenty of its eggs in a nest; and it has several coveys in a scason $[!]$. QUAiss are equally prolific. In the southern and middle States, the quail is called a partridge, and the partridge a pheasant 'The true pheasant is not a native of our wilderness. I'lie late Governor Wentworth bronght several pairs of pheasants from England, and let them 
fly in his woods, at Wolfborough; but they have not since been seen.

WILD PIGEON,

Columba migratoria [Ectopistes migratorius ].

Wild pigrons come in the spring, from the southward, in great flocks, and breed in our woods, during the summer months. They choose the thickest parts of the forest, for the situation of their nests. Jossely'n says 'they join nest to nest, and tree to tree, by their nests, many miles together. on the pine trees.' In the journal of Richard Hazzen, who surveyed the Province line, in 1741 , there is this remark; 'for three miles together, the pigeons nests were so thick, that five luundred might have been told on the beech trees at one time; and could they have been connted on the hemlocks, as well, I doubt not but five thousand, at one turn round.' 'This was on the western side of Connecticut river, and eastward of Deerfield river. Since the clearing of the woods, the number of pigeons is diminished.

TURTLE DOVF,

SKY LARK,

MARSH LARK,

ROBIN,

THRUSH,

THRASHER, OT MOCK BIRD,

CHERRY BIRD,

Cross BII,
Columba carolinensis [Zenaidura macroura].

Alauda alpestris [Otocoris alpestris ].

Alauda unagna [Sturnella magna]. Turdus migratorius [Merula migratoria].

Turdus rufus [Hylocichla sp.?].

Turdus orpheus?' ['Toxostoma rufum.

Ampelis garrulus [Ampelis cedrorum].

Loxia curvirostra [Loxia curvirostra minor].

The CROSS BILL is a bird rather larger than the sparrow; it is common in the western and northern parts of the State. The upper and lower parts of its beak cross each other like a pair of shears, by which means it cuts off the stalks of wheat and rye, and then lays the side of its head to the ground to pick the kernels. The female is of a sliaded olive colour. The male is of the same, but tinged with red.

SNOW BIRD,

Emberiza hyemalis? [Passerina nivalis and Junco hyemalis ].

The SNOW BIRD is smaller than a sparrow, and appears in little flocks, in the winter, enlivening the gloom of that dreary season. They perch on the tops of the spires of dead grass, 
ahove the snow, or on spots of bare ground, or on the bushes and trees. They are seldom molested, as one of them is scarcely a mouthful; but they have the same delicate taste as the quail. Besides the snow bird, the crow, the blue jay, the wood pecker and the partridge, have a degree of hardiness, equal to the severity of our winters, and are then seen flying; all others aroid it, by seeking a timely retreat.

BOBLIXCOLX,

REDTLINAET,

CHEEWEEH,

YELLOW BIRD,

WINTER SPARROW,

CHIPPING BIRD,

SPRIIG BIRD,

Several species of SPARROW',

CRESTED Fi, YCATCHER,

HEDGE BIRD,

CAT BIRD,

BROWY FLYCATCHER,

YELLOW CROWX,

GRAPE BIRD,

BIUE BIRD,

CRESTED WREX,

COMMON WREN,

CRested Titmouse,

BLUE TITALOUSE,

TON TEET,

YELLOW RUMPED TOM TEET,

ITTLE HAXG-BIRD,

BaXk SwALIOW,

BIACK MARTIN,

BARI SWALLOW,
Emberiza oryzivora [Dolichouyx oryzivorus ].

Tauagra rubra [Piranga erythromelas].

Fringilla erythrophthalma? [Pipilo erythroplithalmus].

Fringilla tristis? [Astragalinus tristis ].

Fringilla grisea [Spizella monticola?]

Fringilla? [Spizella socialis].

Fringilla [Nelospiza melodia].

Fringilla.

II uscicapa crinita [Myiarcluus crinitus].

Muscicapa camadeusis [?].

II uscicapa carolinensis [Galeoscoptes caroliueusis].

M uscicapa fusca [Sayornis phøebe]

M uscicapa flava [Regulus satrapa].

Motacilla icterocephala [?].

Motacilla sialis [Sialia sialis].

Motacilla regulus [Regulus calendula].

Motacilla trochilus [Troglodytes aedou ].

Parus bicolor [?].

Parus anericaus [?].

Parus atricapillus [Parus atricapillus ].

Parus virginianus [Dendroica corollata].

Parus pendulinus? [Vireo olivaceus? ]

Hiruudo riparia [Riparia riparia].

Hiruudo purpurea [I'rogue subis].

Hirundo subis [Hiruudo erytlirogaster].

The SWAI, I. W appears in April, and disappears in August. It was formerly supposed to migrate, but the evidences of its retiring to the water, or marshy ground, and there remaining torpid, during the winter, are so many, that this opinion is now generally received.

ChIMNEY SWALLOW,

IIrundo pelasgia [Chatura pelagica ]. 
WHIP-POOR-WV1LL,

NighT HAWK,
Caprimulgus europaus [Antrostomus vociferus].

Caprinulgus antericanus [Chordeiles virginianus ].

Additions to the zoological catalogue by MR. PECK.

\section{PIGEON HAWK, \\ FisH HAWK, \\ HORNED OWI, \\ Or, 1 WIFE, \\ MURR, \\ PETTTERIL,}

LARGE SPOTTED LOON, DOBCHICK or No TAII,
Falco subbuteo [?]

Falco haliaetus [ Pandion haliaetus carolinensis ].

Strix bubo [Bubo virginianus].

Anas hyemalis [Harelda hyemalis ].

Alca torda [Tria lomvia].

Procellaria pelagica [Oceanodroma leucorhoa?].

Colymbus glacialis [Gavia imber].

Colymbus podiceps [Podilymbus podiceps ].

For nearly seventy years after Belknap's list, we find practically nothing on New Hampshire ornithology, save a few scattered notes of little importance. After this long season of quiescence, however, comes a period of considerable activity among our ornithologists. In 1869 and 1870 , Mrs. Celia Thaxter contributed a series of articles to the Atlantic Monthly, entitled "Among the Isles of Shoals," and these contain much of interest in regard to the bird life of that locality. In 1870 , also, as part of the appendix to William Little's "History of Warren," is found a mainly nominal list of 143 birds, which, however, appears not to have been the result of original observation, and is of no special importance. In 1872 , appeared the first really scientific paper of note upon the birds of New Hampshire, that of Mr. C. J. Maynard on the Birds of Coos County, N. H., and Oxford County, Me. This list, with its all too brief annotations by the author, supplemented by a few notes from Mr. William Brewster, still remains the only list of birds of the northern part of the State. In Volume I of Hitchcock's Geology of New Hampshire, published in 1874 , is found a list of birds then regarded as more or less characteristic of the faunal divisions of the State, but it is not clear whether these are to be considered as birds actnally observed in New Hampshire. An 
interesting article on the Summer Birds of the White Mountain Region, by H. D. Minot, is found in the American Naturalist of 1876 . Herein are detailed notes on the birds observed by him at Bethlehem, constituting one of the first important papers on the avifauna of the White Momntains. At about this time, also, valuable lists of birds, with annotations, from Webster and Hollis, appeared in Forest and Stream, the result of observations by Mr. C. F. Goodhue and Dr. W. H. Fox respectively. During the next decade much valuable data relating to the birds of the State was contributed in the form of notes or short articles in the Bulletin of the Nuttall Ornithological Club, notably by Messrs. T. M. Brewer, William Brewster, Ruthren Deane, W. H. Fox and H. M. Spelnan. In I 887 appeared Dr. A. P. Chadbourne's List of the Summer Birds of the Presidential Range, followed the next year by two short lists of summer birds seen at Holderness, Bethlehem and Franconia by Messrs. IV. Faxon and J. A. Allen, and a third list, in I889, of the summer birds at Bridgewater and Moultonborough, by Mr. F. H. Allen. These catalogues were fairly complete and added much to the knowledge of a region but little studied at that time. In these years, also, appeared a number of short articles by the lamented Frank Bolles, dealing in a popular way with the wood life of the Chocorua region. These essays were later brought together into book form in an attractive rolume entitled "At the North of Bear Camp Water." Since I 884 , a number of delightful essays have appeared from time to time, in the Atlantic Monthly, from the pen of Mr. Bradford Torrey. These deal chiefly with the life of the Franconia region, and have done much to stimulate interest as well as add to our knowledge of the flora and fauna of this part of the monntains. 'These articles are also to be found collected in several small volumes, such as "The Foot Path Way," "Footing it in Franconia," and others. An attempt has been made at Dartmonth College to arouse interest in the study of the local flora and fanna, and to this end there appeared, in I89I, a List of the Vertebrates I'onnd within 'Thirty Miles of Hanover. This seems to have been intended only as a preliminary cata- 
logue, and gives no specific records or dates, while including a number of species whose occurrence in the vicinity is much to be doubted. The plan of mapping and studying the local fan1a is, however, a most commendable one and well merits furtlier extension. Beyond the few occasional notices or short articles dẹaling with New Hampshire birds, published in the $4 u k$ and other journals or books, the most important of recent contributions to the ornithological literature of the State are mainly in the way of local lists. Chief among these are Mr. Ned Dearborn's Peliminary List of the Birds of Belknap and Merrimack Connties, in 1898 , and the Preliminary List of Birds Observed in the Vicinity of Manchester, by Messrs. F. W. Batchelder and E. H. Fogg, in I goo. The former of these includes rgi species, is well annotated, and forms a most welcome contribution. A number of the less common species are included on the authority of Mr. C. F. Goodhne, of Webster, a careful and trustworthy observer. The Manchester list, though meager in its annotation, is, in the main, reliable, and evidences care in preparation. Neither list attempts to give exact dates of migration or of special records in most cases. A still more recent contribution to the knowledge of the birds of central New Hampshire is a list of birds observed about Newfound Lake, prepared by Mr. R. H. Howe, Junior, in rgor. A few other short local lists, published here and there by amateurs, attest to the increasing interest in the study of! birds, though the beginner's eagerness to make a "record," or his too hasty and often erroneous identifications frequently detract much from the value of such contributions.

At the end of the present list is given a bibliograpliy including such references only as have been found of value for the purposes of the present paper. These, however, are believed to include practically all articles of importance in this connection, though a number of minor titles are omitted. It has not been possible, however, to consult, in this connection, the "Hawks of New Hampshire" (Manchester Union), I893, and the "Museum Bulletin" (Weirs), i 886, of whose existence the writer knows only at second hand. 


\title{
THE FAUNAL AREAS OF NEW HAMPSHIRE.
}

\author{
TOPOGRAPHY.
}

The State of New Hampshire is roughly triangular in outline and stretches from the northeastern boundary of Massachusetts northward to Canada. It lies in central New England, between latitudes $42 \mathrm{deg}$., $40 \mathrm{~min}$., N., and $45 \mathrm{deg} ., \mathrm{r} 8 \mathrm{min.}$, $23 \mathrm{sec}, \mathrm{N}$, and includes a great variety of country. In his account of the topography of the State, Hitchcock ('74) distinguishes six natural divisions. At the extreme southeast is what he terms the Coast Slope; lere the land gradually rises westward from sea level along our limited shore-line to the slight divide of from two hundred to four hundred feet, rimming the Merrimack basin. To this area belong the Isles of Shoals, some of which are politically a part of the State of Maine. Beaches and salt marshes occur along the coast, and numerous small hills rise on the inland slope. The second division is that of the Merrimack basin, embracing much of the drainage area of that river from the White Mountains and Winnipesaukee districts southward, and broadening out towards Massachusetts. Its western rim is the long ridge which borders the Connecticut valley on the east, and which is really an extension of the White Mountain region. This ridge culminates at the south in Mt. Monadnock (3 $166 \mathrm{ft}$.) but a few miles from the Massachusetts line. The Connecticut valley forms the third district. The river itself is the western boundary of the State, and much of its basin lies in Vermont. Its broad, sweeping meadows, hemmed in by the ridge on the east, mark it off distinctly from the rest of the State. 'The source of the stream is the Comnec- 
ticut Lakes in Coos Connty. A number of side streams flow in from the east, the largest being the Ammonusuc, whose source is among the White Mountains. The fourth and smallest district is the Winnipesaukee basin. Lake Winnipesaukee is the largest sheet of water in the State, and has nearly as many authentic spellings as it has islands. Professor Hitchcock states that the district itself is normally a plain, on which are imposed four small and isolated mountain masses, viz.: the Gunstock and Belknap mountains, Red Hill, the Ossipee hillsand Green Mountain in Effingham. Much of the land area is of dry, sandy plains, supporting a considerable growth of pitch pines (especially about West Ossipee) as well as thickets of gray birch and bear oak. These sandy plains stretch northward to the fifth district or White Mountain area. This embraces the highest peaks in the State, and New England as well. Professor Hitchcock distinguishes ten separate groups of mountains, of which the chief are: the Sandwich range on the south, including the peaks of Chocorua, Passaconaway, Whiteface and Sandwich Dome; the Twin and I afayette group on the west, with Moosilauke ( $48 \mathrm{I} \mathrm{ft}$. ) slightly apart to the southwest; the Carter group on the east, including a number of peaks from North Kearsarge to Mt. Surprise at Gorham, and culminating in Carter Dome ( $4860 \mathrm{ft}$. ' Finally, there is the great central mass of the Presidential range. This includes six peaks of over 5000 feet allitude, viz.: Monroe, Clay, Jefferson, Adams, Madison and the majestic Washington itself, towering up 629 I feet above sea level. Of the large rivers rising among these mountains, may be mentioned the Ammonusuc, flowing to the Connecticut, the Pemigewasset, which becomes tributary to the Merrimack, and the Saco, which flows eastward outside our boundaries, crosses Maine, and empties into the Atlantic. The sixth and last topographical district is that of the extreme northern part of the State, and includes most of Coos County. It is mountainous, though peaks of over 3000 feet are exceptional. Much of it is yet primeval forest, and it is but sparsely settled. Two depressions enter this area from the south. The first follows the Androscoggin river up to Lake Umbagog 
(1256 ft.); the second follows the Connecticut up to the Connecticut I,akes at $1619 \mathrm{ft}$.

LIFE ZONES.

From the foregoing, it is at once apparent that New Hamp. shire offers unusually diverse conditions of enviromment, from the sand dunes and salt marshes on the coast and the broad valley bottoms of the southern and central portions, to the coniferous forests of the north and the small, yet not inconsiderable, Alpine areas on the summits of its highest peaks.

There are represented by the fauna and flora of the State no less than five life zones, characterized by their peculiar species of animals and plants, as follows:-

Upfer Austral. The slight trace of an upper austral element forms no stable part of our fauma, and may be considered as in large measure fortuitous. The White-eyed. Vireo (I'ireo noveboracensis) is stated to breed rarely at Manchester, which, perhaps, might not be surprising when we recall that this is the single location in the State, according to the chart given by Hitchcock ('74), whose mean temperature during June, July and August is $70 \mathrm{deg}$. F., the temperature which practically limits the 11 pper austral zone to the north (Merrian, '98, p. 55). This record, however, is open to some doubt. No upper austral birds are actually known to breed in New Hampshire, though several have been recorded as stragglers. Thus, on August 7, I880, a pair of Carolina Wrens (Thryothorus ludovicianus) was observed at Rye Beach by Mr. H. M. Spelman, and in the Connecticut valley, near the southwestern border, the Orchard Oriole (Ictcrus spurius) has been recorded from Brattleboro, I't. (Howe, : 02). New Hampshire cannot be said, lowever, to include any considerable area of upper austral territory, and the occurrence of species characteristic of this zone is linited only to such plainly isolated cases.

Transition. This is an area of interdigitation and overlapping of the ranges of northern and southern species, and includes much of the open valley land along the courses of the larger rivers up to about the 6oo-foot level, or even locally to 
1,500 feet in favorable valleys of southeru exposure. In general, it embraces the low area aloug the coast, a large tongue of low conntry following the Merrimack and its side valleys, to the sand plains of Lake IVinnipesankee and the valleys which penetrate still farther to the foot of the IVlite Monntains. The bottom lands of the Commecticut are also to be included within the Transition area so far up at least as Lancaster, and Transition species work up the side valleys even to the 11orth side of the White Monntains. The Androscoggin valley also brings Transition forms into the low country to the northeast of these high nonntains. In the northern part of the state, the Transition area is linited rather closely to the flood plains of the rivers and the cleared or settled portions of their banks near at hand, for the sub-Canadian woods here conse down to a low altitude. From an exanination of the nuap illustrating the climatology of the state in Hitclicock's Geology of New Hampslire, it is seen that this area coincides in a general way with tliat included by the summer isotherm of 65 deg. F. as an upper limit, thus showing close agreenent with Dr. Merriam's ('9s) deternination that the isotherm of $64 \mathrm{deg} . \mathrm{F}$. (summer) is the sontlıern linit of the Canadian zone.

The effect of clearing off the heavy primeval forest by 11 an in his progress up these sane valleys has doubtless been to extend in great neasure the Transition area. Thus, anong the White Monntains, where, within historic times, stood lofty forests on the rich valley floors, are now broad meadows where Bobolinks, Vesper Sparrows, Savanna Sparrows, Red-winged Blackbirds, and less often, Meadowlarks find congenial surroundings, and Indigo Buntings, Song Sparrows, Field Sparrows, Catbirds, Brown Thrashers, Kingbirds, Least Flycatchers, Baltimore Orioles and even Wood Thrushes smmmer in the after growth of bushes, or anong the open orchards and shade trees about the farms. As an instance of a species which is even now clearly to be observed thus extending its range, nua be noted the Chestnul-sided Warbler (Dendroica pensylvanica). On several occasions I liave found an isolated pair or two of 
these birds inhabiting the new growth of buslies and vines far in the forest, sometimes within a year or so after the clearing of a patch of heavy timber. The complete change of the cleared territory within a short time, from a dense, damp spruce forest inhabited by a northern fauna, to a dry, sunny, and sheltered area of deciduons bushes and vines, leaves it for a time almost unoccupied, but the keen competition for the available territory of support must soon force tire discovery of the new region by those organisms fitted to inhabit it. Thus it is that some birds already living close at land, such as the Canadian Ruffed Grouse, White-throated Sparrow, Slate-colored Junco, Magnolia and Black-throated Blue Wárblers, are quick to spread into a forest clearing, while a more southern species, such as the Chestnut-sided Warbler, must take much longer to discover the spot and settle there in any numbers. Among the White Monntain valleys, we sometimes see in the same grove, this meeting of northern and sonthern species. Thus in the Saco valley at lintervale, in a large and rather open sugar-maple grove, I have found such species as the Screech Owl and the Wood 'Thrush summering with the Mourning Warbler and the Hermit 'Thrush. Here, evidenth; is not a condition of stable equilibriun. In some years, I have missed the Mourning Warblers from the grove altogether, while again I have found three pairs in ail area so small that the males of all three might be in hearing at one time. 'The Wood Thrush appeared for two y'ears ( 1899 and i90o), but a hasty search in early summer of the third year failed to reveal it again.

Of the 'I'ransition avifauna, we may distinguish a number of birds whose breeding area lies largely to the south, but extends northward into this zone in New Hampshire. Of these birds, certain ones are more or less conmon throughout the area, breeding well up into the valley's of the White Monntains. Such are:-Screech Owl (Mcgascops asio), Whip-poor-will (Antrostomus vociferus), Nighthawk (Chordciles virginianus), Kingbird (Tyrannus tyrannus), Crested Flycatcher (Myiarchus crinitus), Phobe (Sayornis phabe), I, east Flycatcher (Empidonax minimus), Red-winged Blackbird (Agclaius phoniccus), Balti- 
more Oriole (Icterus galbula), Vesper Sparrow (Poxcetes gramincus), Chipping Sparrow (Spizclla socialis), Ficld Sparrow (Spizclla pusilla), Indigo Bunting (Cy'anospiza cjanca), Scarlet Tanager (Piranga crythromelas), Loggerhead (or Migrant) Shrike (Lamius ludovicianus), Pine Warbler (Dendroica vigorsii), Catbird (Galcoscoptes carolinensis), Brown Thrasher (Toxostoma rufum), Honse IVren (Troglodytes acdon), White-breasted Nuthatch (Sitta carolinensis), and Bluebird (Sialia sialis). Others of these southern birds barely reach the valley's of the lower part of the state, or follow them up for only a short distance. 'Thus the Green Heron (Ardea rircscons) follows the streans and lakes of central New Hampshire as far as Wimipesatukee, and a few occur in the lake basin beyond to Ossipee, but from the 'Transition valleys of the White Monntains it is absent. The range of the White Oak (Qucrus alba) in New Hampshire nearly coincides with that of this heron. The tree is one of the more southern varietics and its distribution in the state has been mapped in a general way by IV. F. Flint in Hitchcock's Report. It is not uncommon as far north as Holderness and Ossipee, and in the Commecticut valley slightly farther north at Hanover. IVild 'Turkeys (Mclcagris gallopavo fera) in former times, and Bob-whites (Colinus virginianus) appear normally to find their breeding range to the south of Lake Wimipesaukee. The Yellow-throated Vireo (Virco flavifrons) is another bird of this class. It becomes rare in the upper Merrimack valley, and in the central part of the state is not yet known to occur notth of the Lake. The single bird observed by Mr. Bradford 'Torrey at Franconia is evidently a straggler. So, too, of the Grasshopper Sparrow (. 1 mmodramus savannarum passcrinus), Bartramian Sandpiper (Burtramia longicauda) and Cowbird (Molothrus ater), few seem ever to pass regularly nortl of Irake Winnipesaukee in the central and eastern parts of the state, althougl the broad Connecticut valley, in the west, carries several of these species farther northward than they occur in the eastern regions. Thus the Cowbird is common in this valley at least as far up as Lancaster, though practically absent in summer from the entire IVlite Mountain region. 
The Bronzed Grackle is also of regular occurrence well up the Connecticut and even about Lake Unbagog, yet I have no knowledge of it in central New Ilampshire north of Winnipesankee. Thie Yellow Warbler (Dendroica cestiva) is also to be added to this category of bircls absent from the 'Transition valleys of the White Monntain area but common in sonthern New Hampshire and far up the Connecticut valley. The Golden-winged Warbler (Hclminlhophila chrysoptcra) and the Prairie Warbler (Dendroica discolor) may be mentioned as two Transition species whose breeding range barely extends to the southern borders of the state in the Merrimack valley.

Of the occurrence of southern plants in the Transition zone of New Hampshire, it may be noted that the Chestmut (Castanea) and the Hickory (Carya) occur nearly as far up the valleys as does the IVhite Oak; the Red Oak, however, ranges yet farther, entering the sub-Canadian zone. 'The Mountain Laurel (Kalmia latifolia) also occurs locally as far north as Conway. In his chipter on the Physical History of New Hampshire, Professor Hitchcock adduces evidence indicating that subsequent to the glacial epoch, and probably within the human period, there was an era when the climate of New Hampshire was milder than it now is. In support of this conclusion, is mentioned, among other things, the occurrence of a few sonthern plants in isolated spots far from their present range of abundance. Thus the Rhododendron maximum is reported from Fitzwilliam, Grantham, Hooksett, Hopkinton, Nanchester, and Richmond, and its presence at these places in isolated swamps is taken as indicative of its former abmulance in intermediate localities. At Manchester, also, there occur with the Rliododendron, a few 'lupelo trees ( $N_{y} y s s a$ sylzatica) and from Wincliester, in the extreme sonthwest corner of the state, the Climbing Ficrn (T.rgodium falmalum), a southern species, has been recently recorded (Rhoclora, 1902, 1) 83).

An interesting bird, which secms to have become adlapted to the small and scallered cold-water swamps of the Transition zone grown thp to sedges, and coarse grass, steeple bushes or hellebore, is the Henslow's Sparrow (Ammodramus henslowii) 
which may perhaps be considered as peculiar to the 'T'ransition area as any of our birds. It occurs locally in several places in the central part of the State, and I fonnd a single pair even so far up as Wonalancet, near tle foot of MIt. I'assaconaway, in a corner of a broad meadow which was grown up to seclgres, grass, and white liellebore with a sparse covering of wet Spliagnu11 1110ss.

Of other aninals ranging northward into the 'I'ransition area of New Hampslire, nuy be mentioned, among mammels, the southern Filying Squirrel (Sciuropterus zolucella) which occurs at least as far as I ake Winnipesanke, the northeastern Gray Squirrel (Sciurus carolincusis leuctis) which even among the White Monntains, inhabits the becel woods at the lower altitudes, and the eastern Cottontail Rabbitt (Lepus floridanus transitionalis) which is reported from as far as Welster, where it appears to have come within recent years. Anong reptiles, the Box 'Tortoise (Cistudo curolina) has been reported from Pelham and from Lee, in the sontheastern corner of the state, by Mr. W. H. Huse (:OI). The same author finds the Yellowspotted Tortoise (Chclopus guttatus) comnon about Manchester in the Merrimack valley, but I do not know of its occurrence north of Irake IVinnipesankee, and anong the White Mountain valleys, the Painted Tortoise (Chryscmy's picta) is the only species I have ever seen. The Ribbon Snake (Thammophis saurita) follows the valley bottoms at least as far np as Intervale, where I have not infrequently found it.

A number of more northern species may also be enumerated as funding their sonthern breeding linit within the Transition zone. Such are the following among the birds: L,oon (Garia imber), Hairy IVoodpecker (Dryobates rillosus), Olive-sided Flycatclier (Contopus borealis). Purple lincli (Carpodacus purpurcus), Savanna Sparrow (.I mmodramus sandaichcris savanna), Swanp) Sparrow (Mclospiza gcorgiana)?, Blue-headed Vireo (Virco soliturius), Nasliville Warbler (Hclminthophila mubicapilla), Black-throated Green Warbler (Dendroica wirens), Chickadee (Parusatricapillus), and Hernit Thrush (Hylocichla guttata pallasii). 
It is clear that a "line" cannot be sharply drawn between the Transition zone and the Canadian zone directly above it, as some have attempted to do, but the boundaries of the two overlap and interdigitate in a most intricate manner, and mucl yet remains to be done towards the determination in a precise way of the details of distribution of the two areas in New Hampshire.

Canadian. This fannal area is very well marked and embraces much of the forested area of the state. 'T'wo divisions may be distinguished, the sub-Canadian and the upper Canadian. 'The sub-Canadian includes the white pine woods, the mixed hemlock, beech, birch and maple forests and occasional red spruce thickets of the lower half of the state from nearly the 600 foot level up to about 3,000 feet among the White Monntains, varying more or less according to slope exposure or local condition. 'These woods, though in the main rather dry, are nevertheless well watered by the many little monntain brooks, which by their coldness, often carry down along their courses tongues of the damp, richer npper Canadian vegetation. Among the White Mountains, these lower woods are for the most part mixed beech, hemlock, canoe and yellow birch, poplar, together with more or less red spruce. The forest floor is damp, with an undergrowtl of monntain and striped maple, connels, and hobble bushes, especially along the little streams, and here breed Black-throated Blue Warblers (Dcndroica camlescens), Magnolia Warblers (Dondroica maculosa), 'Water-Thrushes (Seinms viowcboracensis), Mourning Warblers (Geothlypis philadclphia), Canadian Warblers (IVilsonia Canadensis), WVinter Wrens (Olbiorchilus licmalis), Golden-crowned Kinglets (Kegulus satrapa) and Olive-backed 'T'hrushes (Hylocichla ustulater saudinsonii), while anong the forest trees close at liand live Hairy Woodpeckers (Dryobates illosus), Yellow-bellied Sapsuckers (Sphyrapicus a'arius), Northern Pileated Woodpeckers (Ceophlaus pilcatus abicticola), Olive-sided Iilycatchers (Contopus borealis), Bluc-lieaded Vireos (IFirco solitarius, Blackburnian Warblers (Dendroica blackbumice), Anerican Brown Creepers (Corthia familiaris ammicana), and Red-breasted 
Nuthatches (Sitta canadonsis). At the lower elevations, groves of White Pine occur, usually below Soo feet, though scattering trees are to be found, often of great size, 11p to 2,500 feet or slightly less. These pine groves are carpeted with needles, which make a dry and often rather barren floor. Here we find such sub-Canadian species as Slate-colored Juncos (Juncoliycmalis), Myrtle Warblers (Dendroica coronata), Blackburnian Warblers (Dendroica blackbnmia) and Hernit Thrushes (Hylocichla guttata pallasii). A number of these sub-Canadian species are rather sharply limited in their breeding range by the upper Canadian zone, and occur only rarely on its lower edge. Such are the Yellow-bellied Sapsucker, Olive-sided Flycatcher, Blue-headed Vireo, Black-throated Blue Warbler, Magnolia Warbler, Bay-breasted Warbler, Blackburnian Warbler, and Oven-bird. In a general way, the 3,000 foot contour marks the lower edge of the upper Canadian zone on the higher mountains where the slope exposure is to the south. On northern, shaded slopes, this limit is some 500 to I, ooo feet lower, and on both north and sonth slopes the cold monntain streans serve to carry down with them strips of the upper Canadian as narrow tongues into the lower woods. In a region still covered by primeval forest, the upper Canadian area is 110ticeably lower on the momntains than on territory which has once been stripped of its heavy growth. T'lus in the undefiled forests of the upper Pemigewasset, Canadian Spruce Grouse (Canachites canadensis canace) ocenr along the stream at least down to 2,000 feet, though on the nonntains which have been burned or lumbered, only deciduous or mixed growth is found at this level, quite unsuitable for high northern species. An interesting observation I have several times made among the damper, higher woods of the sub-Canadian area on the White Mountains, is that the Lady's Slipper (Crpripodium acaule) growing from $I, 800$ to 2,500 feet or so, is prevailing white instead of pink. In late June, I900, almost three fourths of the numierous blossoms seen on the Carter Notch and Nineteen-1nile Brook trails, were snow white or barely flushed with pink above I, Soo feet, and again in nid-June, 1902, along the same trail, 
sixteen ont of serenteen blossons seen, were white. Possibly the increasing dampness of the ground and the air at these higher levels may be a factor in bringing about this clinge. Above 3,000 feet the plant does not occur. Unfortunately no record of temperatures for these Canadian woods is at present available for use here, but Dr. Merrian gives the limiting temperatures (summer) as about $57 \mathrm{deg}$. to $6+\mathrm{deg}$. F.

The upper Canadian area includes the thick fir and spruce forests in the northern part of the state and on the White Mountains from 3,000 to 4,500 feet. Extended observations on the temperature and humidity of this area are not at hand, but among the White Monntains it is a zone of much greater cold than the sub-Canadian. The forests are clense and are kept saturated in summer by the clouds which constantly settle over them; the ground is densely carpeted with spliagnum which acts as a huge sponge to retain water from the slowly melting snow drifts. Ice is often found under sheltered rocks into July, and even by the middle of June snow drifts are hardly gone in the woods. While on a few days' camping trip into the Carter Monntains, June 13 to 16 , we found that the yellow pond lilies (Nymphaa raricgata) in the Carter Lake at 3,360 feet, had not yet pushed their leaves to the surface of the water, though in the Transition valleys we had seen many plants in blossom along the way. Here the canoe birches were just leafing out, five weeks later than those in the valley below; here and there were violets (Viola blanda), and White Hellebore and ferns were just springing 11p from places where the snow was scarcely gone. Clintonias were only in bud, though 2,000 feet below in the sub-Canadian woods they were in full bloom. In the little lake numerous toads (Bufo Amcricanus) were beginning to spawn. They are common throughout these mountain woods to the limit of timber, and numbers had repaired to this lakelet to breed. Some had not yet begun to spawn, though others had already laid considerable masses of eggs. In eastern Massachusetts, the toads spawn about the 20 th of April and the young tadpoles are seen by the middle of May, or even by the first of that month. On a former occasion, I had fonnd great 
numbers of small tadpoles in Carter Lake by the 22 l of July. The following sixteen breeding bircls are clraracteristic of this upper Canadian zone in New Hampshire: Canadian Spruce Grouse (Canachites canadcusis canace), American Cioshawk (Accifitc') atricapillus), Arctic 'Three-toed Woodpecker (Picoidcs arcticus), American Three-toed Woodpecker (I'icoides amcricanus), Yellow-bellied Fiycatcher (Empidonax flarivontris), Canada Jay (Perisorcus canadensis), Rusty Blackbird (Scolccophagus carolinus), Canadian Pine Grosbeak (Pinicola cnucleator loncura), White-winged Crossbill (Loxia leucoptcra), Pine Siskin (Spimus pinus), 'Tennessee Warbler (Hclminthophila porggrina), Cape May Warbler (Dcndroica tigrind), Black-poll Warbler (Dcndroica striata), Wilson's Warbler ( Vilsonia pusilla), Hudsonian Chickadee (Parus hudsonicus), and Bicknell's 'Thrush (Hylocichla alicice bicknclli).

Of manmals characteristic of this area are the Rock Vole (Microtus chrotorrhinus) (?), Canada White-footed Mouse (Peromyscus canadinsis), Woodland Jumping Monse (Napaozapus insignis), Canadian Red Squirrel (Sciurus hudsonicus gymnicus), Smoky Shrew (Sorcx fumcus). Water Shrew (Sorcx albibarbis), Canada I,ynx (Lynx canadonsis), Sable (Mustela americana), Pennant's Marten (Mustclla pennanti).

In addition to the species more or less strictly confined to each of these two subdivisions of the Canadian zone, may be mentioned a few which are common to the area as a whole. Such are Saw-whet Owl (Nyctala acadica), Hairy Woodpecker (Dryobates villosius), White-throated Sparrow (Zonotrichia albicollis), Slate-colored Junco (Junco hycmalis), Nashrille Warbler (Hclminthophila rubricapilla), Myrtle Warbler (Dcndroica coronato), Winter Wren (Olbiorchilus hiemalis), Red-breasted $\mathrm{N}$ uthatch (Sittu canadcnsis), Golden-crowned Kinglet (Regulus satrapa), and Olive-backed Thrush (Hylocichla ustulata swainsonii); also the following mammals: Northern Virginia Deer (Odocoilens virginianus borealis), Canada Porcupine (Erithizon dorsatum), Easteru Varying Hare (Lcpus americanus virginianus), Mink (Putorius aison), Black Bear (Ursus amcricanus), Masked Shrew (Sorct porsonatus). 
In passing, a word may be added with regard to the cliange wrought anong these rich monntain woods, by fire. Many of the lower peaks and ranges, such as Kearsarge, the Moats, the Rattlesnake range, and others, have been more or less completely burned over by forest fires during the last century. Fires once started in these old forests are not readily stamped ont, a damp substratun offering but little hindrance to their progress. The trees are usually killed by the heat and partially charred, but most of then remain standing and soon become withered and exceedingly hard and dry. The soil bencath is quite denucled of covering, and along the ridges it soon washes away, learing bare rocks and ledges. It is long before such an area is again clothed with verdure. Small blueberry bushes are anong the first plants to spring up, and sparse grass and fireweed (Epilobium) follow. Eventually the old fire-killed timber falls from the washing away of the soil and decaying of the roots, and a new growth of birch and poplar slowly takes its place. These trees, well adapted to a thin soil, serve to keep the substratum from washing completely away, and in time a new forest is formed, though different from the original one, while the many exposed ledges and bare, rounded ridges testify to the extreme difficulty of creating a new soil in place of that worn away by the exposire.

Hudsonian. This life zone is not well defined in New Hampshire. In the extreme northern part of the state, it is possible that well marked tongues or islands of this area occur, as at the Connecticut I akes, where Woodland Caribou (Rangifor caribou) occur about the cold bogs, and Pine Grosheaks snmmer in numbers. On the White Mountains the Hudsonion zone may be considered as including the belt of stunted fir balsan and sprnce from abont 4,500 feet up to 5 ,ooo feet on sonthern slopes, the lower linit dipping to perhaps 4,000 feet on sone northern exposures. 'This is the "scrub" of the mountaineer, and forms an exceedingly dense and stubborn barrier to hin who tries to force a passage through. Its avifanna is not characterized by the presence of any strictly Hudsonian species, so far as present observations go, a fact which is donbtless due to its limited 
extent. 'The few species of birds fonnd in it are those conmon to both the upper C'anadian and the Hudsonian zone. Doubtless the npper Canadian spccies readily spread into it from below and true Indsonian species, if not crowded ont, would at least find its area too limited for regular occupation. The following birds are found to occupy this area regularly, and doubtless breed in it: Canadian Spruce Grouse (Canachites canadcnsis canace), White-throated Sparrow (Zonotrichia albicollis), Slate-colored Junco (Junco hyemalis), Myrtle Warbler (Dendroica coronata), Black-poll WVarbler (Dcudroica striata), Hudsonian Chickadee (Parus hndsonicus), and Bicknell's 'Thrush (Hy'locichla alicie bicknclli). A few other species wander up to this height more or less frequently, but probably do not breed above the upper Canadian; such are Canadian Ruffed Grouse (Bonasa umbellus togata), W'hite-winged Crossbill (Loxia lacoptera), Nasliville Warbler (Helminthophila mbricapilla) and Goldencrowned Kinglet (Kegulus satrapa).

Mr. Samnel H. Scudder, in his report on the Distribution of Insects in New Hampshire (Hitchcock, '74), refers to this zone under the name of "sub-Alpine." He finds that certain insects whose habits render them nore or less local, are quite characteristic of this division, and gives, as two species which seen peculiar to this region in New Hampshire, a butterfly (Bronthis montinns) and a grasshopper (Podisma glacialis).

Arctic-Alpinc. 'This is the treeless, "barren ground" area, limited in New Hampslire to the summits of certain of the highest monntains. In general, it includes the peaks of the Presidential range above the level of 5,ooo feet, having thus a vertical extent of about I, ooo feet to the top of Mt. Washington $(6,29$ I feet). Much of it is a region of boulder-strewn slopes, though the more level parts, or "lawns," support a matted turf of wiry sedges, together with a number of alpine flowering plants. Though a small area, comparatively speaking, it is, nevertheless, doubly interesting because of its peculiar character and the rigorons conditions of environment which it affords. From the observations made at the stunmit station on Mt. Washington by officials of the U. S. Weather Bureau, a great 
annount of valuable data has been obtained. In the chapter on Climatology in Hitchcock's Geology of New Hampshire ('74), it appears that for the jears i $853-59$, the mean annual temperature at the summit was 28 deg. F. The mean temperature for the months of October to March, which there are practically winter, was 12.4 deg. F., that for the months of April to September being 39.7 deg. F. The months of June, July and August, which may be taken as the breeding period for birds at this height, averaged for the six years, $44.5 \mathrm{deg} ., 47.9 \mathrm{deg}, .50 .7$ deg. F. respectively. These are the three hottest months of the year at the summit, so that the mean temperature for this period is 47.3 deg. F., with 50.7 deg. Fi. for the hottest single month. This corresponds closely with Dr. Merrian's statement ('9s, p. 54) that the limiting temperature for the lower boundary of the Arctic zone is probably $50 \mathrm{deg}$. F'. for the six hottest consecutive weeks of summer. The local conditions of this mountain summit, however, are doubtless somewhat different from those of the circumpolar arctic region. The report on the Climatology of the state previously referred to, includes an interesting account of certain phenomena of the rigorous winters at the summit of $\mathrm{Mt}$. Washington, describing among others, the remarkable frost feathers which build out into the wind from any stationary object. In summer, cumulus clouds from the heated valleys below often rise so as to envelop the mountain top, or more often Mt. Washington's head alone is shrouded by a stationary cloud. It is stated that at times, the whole country westward is covered with clouds, but that when they have passed the ridge ruming directly sonth from Mt. Washington, they are instantly dissolved, never passing beyond a certain point, though moving at the rate of from fifty to sixty miles an lour. 'The wind at this altitude is frequently terrific. During periods of storm, the wind at the summit is said to increase steadily in velocity till it reaches its culmination, then come lulls, at first only for an instant, and these continually lengthen until the storm ceases. A wind velocity of r 40 miles an hour has been measured, and during one night, the mean of four observations is given as 128 miles. Moreover, it is fonnd 
that often a gale is blowing at the sumunit, while below, lle air is quite still. 'I'hus at one obsesvation, a wind of 96 miles an lour was blowing at the summit of Washington, while 3,000 feet below, at the depot of the Mt. Washington Railroad, there was not sufficient air stirring to move the anemometer. 'The winds of extrenc velocity, however, are usually linited to the winter season or to periods of storm in summer. 'Tlle prevailing winds for the entire year are west and northwest, a fact which may have some bearing on the occurrence at these stmmits of certain wind-blown insects, for a large number of species straggle up froun the surrounding country. Mrs. A. 'I'. Slosson luas collected considerably over a thousand species here during a period of years, and has not infrequently obtained forms belonging to distant parts of the country. 'The tendency of insects to work their way up a monntain is well known. T'lue air currents constantly rise up the mountain sides, for whicl reason the woodsman faces his camp up hill to avoid the smoke of his camp fire. Aided by these currents, multitudes of snall insects may sometimes be seen streaming up from below, and converging at the summit in great numbers. Thus, on one occasion, while on the crest of the Carter range in mid-June, I liave seen the flying Aphidis coming up from the forest-clad country below in comntless numbers, wafted by the gentle upward current of air.

Observations of rainfall for a single year on Mt. Waslington's summit gave 55 inches, of which 47 inches were in stummer and autumn. Other local conditions of this small area incident on altitude and latitude make it a most interesting spot for careful œcological study.

The bird fanna of this arctic-alpine region is small, and includes no species typical' of the zone. 'The White-tliroated Sparrow (Zonotrichia albicollis) and the Slate-colored Junco (Junco hycmalis) are the only two birds which breed lere regularly, and the former occurs only in a few slieltered places on the lower edge of the zone, as at the Lakes of the Clouds. 'The Junco is the only bird one may feel confident of funding even to the summit of Waslington in summer. A number of lowland species wander up to these altitudes irregularly, however, dur- 
ing the summer or on migrations. Thus Goldfincles and Pine Siskins are often seen flying over, and small hawks, Red-breasted Nuthatches and Robins sometimes alight in passing. On one occasion, in mid-July, I eren observed on two consecutive days, a Savanna Sparrow (Ammodramus sandivichcnsis sazanna) singing from a stone anong the sedges, only a short distance from the summit buildings. The bird seemed perfectly at home lere, and was probably breeding.

Of mammals, several species occur on these arctic summits, but these are chiefly Canadian forms. The Varying Hares (Lepus americanus airginianus) seen even to risit the tip-top buildings on Mt. Waslington, and Mr. Thaddens Lowe, of Randolph, tells me of seeing their tracks in the snow about these structures in the late spring. Striped Squirrels (Tamias striatus lystcri), Red-backed Mice (Eiotomy's gatpori ochraccus) and even an occasional Canada Porcupine (Erithizon dorsatum) or Woodehuck (Arctomys monax) have been known to wander up from below, and the last is sometimes seen in 'T'uckerman's Ravine, at over 4,000 feet on Mt. Washington. 'The I, ittle Brown Weasels (Putorius cicognani) and Sables (Mustcla (americana ) are great travelers and go all over these high levels, even traversing the ranges from one forest to another, as I am informed by Mr. V. D. Lowe.

For characteristic arctic animals of this region, we must look to the insects, of which a number of high northern species are known to occur. The most conspicnous of these, at its season, is doubtless the Barren-ground Butterfly Chionobas somidia), which is very closely confined to this treeless alpine area. Its caterpillar feeds on the Carex rigida bigclorii which grows abundantly at these heights.

Of typical arctic plants nuay be mentioned in addition to two or three carices and dwarf willows, the Diapensia lapponica, alpine azalea (Loisclcuria procumbcus), Rhododendron lupponicum, Cassiope hypnoides, all blossoming in June; also the handsone Peck's Geunn (Goum radiatum peckii), found plentifully in July, and the Greenland Sandwort (Arenaria granlandica). A number of other flowering plants occur on these summits, of which 
nearly fifty are stated to be strictly alpine, and many of these are found also on alpine summits in Linrope. Extended lists of the plants occurring in the arctic-alpine zone of the White Mountains are to be found as indicated by the following references :-

1S74. Hitcheock's Geology of New Hampshire, vol. I, p. $392,394,568,572$.

1595. Miller, G.S. Proc. Boston Socicty of Natural History, vol. 26 , p. I 7 S-I 79 .

1900. Among the Clouds, vol. 24, no. 13, p. 3.

Summary. From the foregoing it is seen that the principal fannal areas of New Hampshire are the Transition and the Canadian, the former including most of the valley land of the southern part of the state up to abont 600 feet, as well as long tongues of country in the Connecticut and the White Mountain valleys; the Canadian comprising much of the wooded area of the state from about 600 feet up to about 4,500 feet on the monntains. A mere trace of an Upper Austral fauna is sometimes observed in the lower valleys, and ou the coast at our southeast horder, but forms no stable elenent of the fanna. The Hudsonian zone is limited to a narrow belt of stunted fir and spruce growth on the White Mountains from about,+ 500 feet to 5,000 leet, and may also include a lew small areas in the extreme northern part of the state. Its avifanna, so far as known, consists only of such species as are common. also to the upper Canadian zone. Finally on the extreme summits of the higher White Mountains, above 5,000 feet, is a "barren ground " arctic-alpine zone, possessing no large characteristic animals, but yet supporting a number of small arctic plants as well as ligh northern insects. 


\section{MIGRATION.}

Certain phases of bird migration in New Hampshire are perliaps of sufficient interest to warrant a few remarks in addition to the notes given under the several species in the following list.

The coastwise migration of many of the smaller land birds is worthy of mucl further study. Mrs. Celia Thaxter (' $70, p$. 581 , et seq.) has given a short account, written in her charming way, of the land birds occurring during the migrations, at the Isles of Shoals. Here, at some six or seven miles off the coast of Rye, she writes that about the 27 th of March "the islands are alive with song sparrows. . . . Robins and blackbirds [Agclaius phanicus] appear with the sparrows; a few blackbirds appear and remain; the robins, finding no trees, flit across to the mainland. Yellow-birds [Dendroica astian] and kingbirds occasionally build lece, but very rately. . . . . By the $23 \mathrm{rd}$ of April come the first swallows and flocks of martins [Prognc subis], golden-winged and downy woodpeckers, the tiny ruby-crowned wren [Regulus calendula], and troops of many other kinds of birds; kingfishers that perch on stranded kellocks, little nuthatcles that peck anoug the slingles for hidden spiders. . . . All these tarry only awhile in their passage to the mainland. . . . Now and then a bobolink pays us a flying visit, and, tilting on a blackberry spray, pouns out his intoxicating song; some morning is heard the fairy bugling of an oriole; a scarlet tanager honors the place with half a day's sojourn." 'These migrants may very likely be cutting across the curve of the coast to strike the Maine shores fartlier north, and in fall there seems to be a somewhat similar movement in 
the reverse direction. Mr. A. A. Eaton, of Seabrook, writes me that one day in October, a few years since, as he lay off shore in a boat, great numbers of small birds, mostly Myrtle Warblers, were noted coming in from the northeast, as if crossing from the Maine coast, and the beach itself was swarning with then. This clay was clear, but a storm arose during the following night. Capt. H. L. Spinney ('98) in an interesting account of the 1nigrations at Seguin Island, off the month of the Kennebec River, Maine, states his belief that many of these small birds are actually blown out to sea, and struggle back to land as opportunity allows. He says, "I have been out many mornings in a boat some half a mile or more from the island, waiting for the ducks to come to my decoys, when the day before and during the night the wind had blown very strong from the north or northwest, and about sunrise the small birds would begin to fly in from sea in numbers, from one to three or four in sight at one time. This they would continue to do nutil noon. Many of them wonld be seen to drop in the water so exhansted that even when within a few yards of the island they would have to succumb; others would just reach the shore at the edge of the water. . . . A A though I have seen many of them drop in the water, I have seen but one rise out of it. This was a sparrow, which, rising three times in succession, finally reached the island."

At the Isles of Shoals, MIrs. Thaxter observes that "the lightlouse .... is the destroyer of birds. .... The keeper living at the island three years ago told me that he picked up three hundred and seventy-five in one morning at the foot of the lighthouse, all dead. They fly with such force against the glass that their beaks are often splintered. The keeper said he fonnd the destruction greatest in hazy weather and he thought 'they struck a ray at a great distance and followed it up.' Many a May morning have I wandered about the rock at the foot of the tower, monrning over a little apron brimful of sparrows, swallows, thrushes, robins, fire-winged blackbirds, many-colored warblers and flycatchers, beautifully 
clothed yellow birds, minthatches, catbirds, even the purple finch and scarlet tanager and golden [Baltimore] oriole and many more beside." Captain Spinney finds "warm, cloudy nights, very dark with little wind if any" the most favorable for a large flight of birds at his lighthouse, or when the atmosphere has become smoky from forest fires and there is a clear night with light southwest wind; but " should rain or strong winds come suddenly, all but a few individuals will leave at once, or settle down on the ground." In foggy weather, he has rarely noted birds about the light.

Away from the coast, the main rontes of migration are naturally the north and south trending valleys. One has only to spend a few weeks of late August and early September in a locality not in such a valley to realize how few birds are moving through his territory in comparison with the hosts along the large rivers. In the White Monntain valleys most of the small birds, as warblers, kinglets, vireos and sparrows of varions species, sooner or later collect in the valley bottoms; the robins and cedar birds gather in large numbers about the wild cherry trees by the river, and the bobolinks swarm over the weedgrown fields. The main flight of swallows and nighthawks is confined in great neasure to the river basins, notwithstanding the far roving habits of the birds, and apart from such localities one sees but few of the migrants. A number of waterfowl seem. to pass down the Connecticut valley with more or less regularity, eren such salt-water species as Scoters of three sorts, Oldsquaw and American Golden-eye Ducks, Red-throated Loons, Horned Grebes, and even an occasional cormorant ( $P$. dilophus). Bonaparte's Gulls often stray across the state in late stmmer, and several species of sandpipers, as the Least and Semipalmated, migrate in numbers down the larger water conrses. Mr. William Brewster (:02) states his belief that many of the Red-legged Black Ducks, such as occur in early October at Lake Unbagog, after leaving their breeding gronnds in the interior about Hudson's Bay, strike for the Atlantic coast by the shortest possible route, thus crossing northern New Iingland in their passage. It wonld seen not improbable that other 
waterfowl and shore birds pursue a somewhat similar course, and on reaching our large lakes and rivers often stop to feed or rest.

A number of special cases might be mentioned as of interest. Thus, as stated elsewhere, there seems to be a more or less well defined nuigration of Brunnich's Murres across the lower part of the state in late fall, many bircls seeming to make a cross cut from the Maine coast to the Connecticut valley. Certain northern warblers, as the Tennessee, Cape May, Bay-breasted and Mourning IVarblers, seem to pass over the southern part of the state in their spring flight, and are rarely seen there though conmon in the White Mountains or to the north of them in stmmer. The fall migration of the Black-poll Warblers (Dcndroica striata) is of more than usual interest as observed among the White Monntains. These birds breed commonly in the balsam forests of the upper Canadian zone mainly above 3,000 feet on sonthern exposures, and down to 2,000 feet on the northeril slopes. During September they swarm, in migration, over the low country of the southern part of the state and beyond, but in the ralley bottoms anong the mountains are nsually uncommon, if not rather rare. Here they migrate mainly at the upper levels and along the mountain tops. Thus at Intervale, a carcful search in the lower valleys and woods from the Saco up to some I, 500 feet on the neighboring monntains will frequently fail to discover more than a scattered indivichal or two among the flocks of other small warblers and chickadees, but higher up along the tops of the lower monntains they are fairly common. 'Thus, on September IO, I900, I went up Mts. Bartlett and Kearsarge (northern), the latter 3,260 feet, and on reaching the more open ledges of the former, at about 2,200 feet, at once noticed the numbers of Blackpolls that were passing. Many single birds flew by overhead at short intervals and at 110 great distance above the mountain; most of them were going northward in the face of a light wind, but a number stopped among the clumps of small spruces, balsams and birch which grew among the ledges. A few also were seen in company with small flocks of chickadees and on all sides was heard their fine 
insect-like note. On my descent again into the valley, they were practically left behind after I had passed below the 2,000 foot level. A few days later, on September I3th, among the deeper forests of the Carter mountains, they were found to be common in small flocks. We had noticed a few scattered individuals along the valley road, but on entering the wpland woods at about 2,000 feet, they hecame at once numerous. The following day we found then in numbers among the higher forests on Carter Dome and the nountains beyond. They seemed to be merely roving through the trees in loose flocks, or flying about from one place to another in a restless, aimless way. We camped that evening at the Carter Lakes, and arose early on the morning of the I5th of September after a clear, cold night. The altitude at the lakes is 3.360 feet, and on either side tower the walls of the Carter Notch, a great rift in the monntain with a valley opening out towards the north and another to the south. Shortly after the sun had begun to creep down the farther wall of the Notch, there commenced a large flight of Black-poll and Myrtle Warblers. By singles, pairs, threes, or in small flocks of from four to six birds, these warblers came flying in from the south, high in the air, making straight for the Notch. Many, on reaching this point, kept on over the divide to the northward. Others wavered at the height of land $(3,460$ feet) but still kept on till out of sight, while yet others, and these mainly the Myrtle Warblers, turned to alight among the trees on the monntain side, or about the lakes. This flight continned from $4: 30$ or 5 o'clock a. m., for over two hours, during whicl time. several hundred birds passed, by actual comt. Of these, about one quarter were Myrtle Warblers, the rest Blackpolls. By 9 a. 11 ., only an occasional bird or two was observed, and the flight was practically over. It seemed as if the Blackpoll Warblers from all the forests immediately to the sonth were noving nortl in a concerted manner to the pass through the Notch and off beyond. Possibly they were licading for the Ammonoosuc Valley to continue thence down the Connecticut ; this would be a natural course, and one cannot suppose that their northward flight at this season conld have becu more than sone such local movenent. 
The periodical abundance of certain northern birds, such as Pine Grosbeaks, Redpolls, Pine Siskins, and Crossbills, is a plenomenon of no small interest. Such incursions we look upon as irregular and of haphazard occurrence, for 110 other reason, perliaps, than because we are quite ignorant of the conditions which bring them about. During the fall and winter of IS99-Igoo a notable incursion of Red and of White-ringed Crossbills took place not only over New Hampshire, but over most of New England, and the coast regions farther south. The Red Crossbills appeared first, and were already quite common among the hills of New Hampshire during June and July, I 899. During the two months following they passed through Massachusetts and made their way to Washington and even to Virginia. The White-wings followed closely in their wake and during the last of October were common in eastern Massachusetts, passing through during November and December to the states farther south, reaching New Jersey, Pennsylvania and Ohio. It may be of value to place on record a few facts relative to this flight as observed among the White Mountains during the summer of I899. On June I8, I899, when I reached Intervale, in the Saco Valley, the Red Crossbills were at once noticed as abundant. Usually they are present here in small numbers during summer, but on this occasion their numbers were abnormally large. During the remainder of June and early July, flocks of from seven to twenty were often observed, usually flying southward down the river valley in loose order. After the first week or so of July, although they were still pressent in about the same numbers, no large flocks were noticed, but at the most little companies of from four to six birds, groups of three, and many pairs and singles. In most cases which could be determined, the paired birds seemed to be adult males and females; the former were in bright red plumage and frequently were observed singing as they flew about on fluttering wing or perched among the tree tops. They seemed to feed to a considerable extent on the seeds of the paper birch, and many were also found feeding among elm trees or upon hemlock sceds in the hemlocks. On two trips into the nearby mountains from 
July 20 to 25. it was plain that most of the Red Crossuills were in the valleys, below 1,500 or 2,000 feet. In course of a trip from Intervale over the Presidential Range from Angust 2 to 5 , the same fact was again observed, that practically all the Red Crossbills were left below us when the woods at 2,000 feet were reached, though numerous pairs and a few single birds were fonnd along the Glen road nearly to this altitude. At about this same time, Red Crossbills were common in the lowlands just north of the great range, which they must have passed by following through the varions notches and valleys. The first White-winged Crossbills were noted on the 2oth of July, when a small flock of six birds was found feeding among the spruces at some 2,400 feet on Mt. Bartlett, and on the following day sereral were heard as they flew past overhead while we were going through mixed woods at over 2,000 feet on the Carter Notch trail. A single bird was seen on July $22 \mathrm{~d}$ at Carter Notch $(3,360$ feet $)$, but there seemed to be only a few scattering bircls on the upper levels at this date. A bout the middle of August the number of Red Crossbills seemed to be falling off in the ralleys, and at the same time small flocks began to gather in the lower woods to feed on the ripening seeds of the red spruce and hemlock. This gathering into flocks continued during August, and by the first of September numbers of small bands of from 3 to a dozen birds were found, with sometimes a White-winged Crossbill or two among them. One or two small flocks of the latter had already appeared in the valley also. Firom September 4 to 6 was again spent in the higlier woods of the Carter nnountains, the greatest elevation being the sumnit of Carter Dome (4,86o feet). 'Throughout the lower country, a fair number of Red Crossbills was scen on our trip in, but after getting abore 2,000 feet or so. White-winged Crossbills becane com11011 in flocks of from seven to fifty birds, to the complete exclusion of the Red species. It will be remembered that on the previous trip.s to these upper levels in late July and early August, only a very few White-wings were seen, while now they were abundant. They were extremely restless, and flocks were constantly in sight or hearing, now pitching down into a spruce or 
birch tree to feed on the seeds, then whirling away over the nountain. From early September on, the White-wings were present in the river valley in sull numbers, but not in the abundance seen on the higher parts of the mountains, above 2,500 feet. During the rest of September, both Red and Whitewinged species were daily seen flying sonthward down the river valley, but after the 20 th I was unable to make further observations on then there. The cause of such an unusual incursion is doubtless more or less complex. One factor may be the food supply, of which there was that year an abundance, since spruce, hemlock and birch trees bore heavily, and apparently with numsual luxuriance. The exceedingly dry spring and summer may have had an indirect influence in producing the large crops of seeds in the case of these trees, for the pollen would have escaped being wetted down, and thus a greater number of the fruiting parts may have been fertilized. 
ANNOTATED LIST OF THE BIRDS OF NEW HAMPSHIRE.

1. Colymbus holboellii (Reinh.). HOLBCELL'S GREBE.

Inland, a rare spring and fall migrant; on the coast, it doubtless occurs also as an uncommon winter resident. In the spring of 1876 , several were taken at Webster, and one so late as June, of that year (Goodhue, '77a, p. I46). Mr. Ned Dearborn ('98, p. 3) records one in breeding plumage taken at Alton where it was picked up in a field exhausted; and another shot in the fall at Lake Winnisquam.

2. Colymbus auritus Linn. Horned Gribs.

A regular autumnal migrant to the larger water courses and poinds.

Dates: October to November 20 (Winter on coast?).

3. Podilymbus podiceps (Lim.). PIED-BILLED GreBt.

An uncommon spring and fall migrant, and a rare local summer resident. At IVebster, Mr. C. F. Goodhue ('77, p. I 46 ) used to find it in summer and it doubtless still occurs in the breeding season on some of the lakes in the southern part of the state. In the fall migration, it is not infrequently found in the Connecticut valley, and Mr. William Brewster has formerly found it in small numbers at Rye Beach in fall.

1)ates: March to October 4.

4. Garia imber (Gun11.). I,OON.

A common spring and fall migrant and winter resident along the coast, and common inland in migrations on the larger bodies of water; a few still breed about the lakes in the sonthern 
part of the state, and in the less disturbed regions to the north they are yet fairly common summer residents. "Twenty years ago," writes Mr. Dearborn ('98, p. 3), "they bred every summer at one or more of the headwaters of the Suncook river." 'They still breed at Winnipesaukee and Asquam Lakes. Mr. G. H. Thayer writes me that a pair nests annually at Breed's pond near Chesham, and Dr. W. H. Fox states that a pair bred in I899 at Lake Sunapee. They were known to breed also at Bow pond, Straiford, some I 5 years ago ( W. E. Jenkins, '84, p. 23). Off the coast, at Rye Beach, Mr. William Brewster tells me that barren birds were observed to pass the entire summer on the ocean, while the flight from the north began soon after September ist. During September and October they are common as migrants on the wind-swept lakes and along the coast.

5. Gavia lumme (Gumn.). RED-THROATED LOON.

Inland, a rare fall migrant; along the coast, it should occur as a winter resident. Mr. C. F. Goodhue ('77a, p. I46) records one taken at Webster, in the fall of 1876 , and there is also a specimen in the Acworth Public Library taken at Alstead, November 4,1886 . Mr. G. H. Thayer has noted it as a rare autumn visitant to Dublin Pond.

6. Fratercula aretica (Linn.). PUFFin.

A winter visitant off the coast. Mrs. Celia Thaxter (37o, p. 2 Io) records the "sea parrots" as found in winter about the Isles of Shoals.

\%. Cepphus grylle (Linn.). BLACK Guildeno'T.

A winter visitant off the coast. Mr. A. A. Faton of Seabrook writes me of one taken near there in December, I888. Mrs. Celia Thaxter ('70, p. 210) also mentions it as a winter bird at the Isles of Shoals.

S. Uria lomvia (Linn.). Brunnich's Murres.

A common winter resident along the coast, and of occasional occurrence inland, whither it is sometimes blown by easterly winds. Thus Prof. William Patten writes me of one captured in an exhausted condition by a farmer within two or three miles 
of Hanover in February or Narch of I\$94. A second bird was said to have been taken there at the same time. An interesting and apparently unusual incursion of these birds into the southern part of the state, took place during the last week of Norember, I899, when more than two dozen were taken, as follows: Antrim, one sent in to Mr. J. P. Melzer, Nov. 25 ; Charlestown, one shot Nov. 30, and a second Dec. I, on the Connecticut river; Francestown, one sent in to Mr. Melzer on Nov. 27 ; Franklin Falls, one captured in a brush heap, about the last of November, according to Mrs. Ellen E. Webster; Lake Winnisquam, several specimens were taken, reports from Laconia, Winnisquam and Tilton probably 1 eferring to the same bircls. Meredith Neck, Mrs. Ellen E. Webster (:ooa) writes that three were shot on Winnipesaukee, the locality being as above; Nash$u a$, one found "near a pond," and sent to Mr. J. P. Melzer on Nov. 27 ; Northfield, one taken alive on Bean Hill according to Mrs. Webster (in literis); Tilton, two sent to Mr. C. F. Goodhue, were shot here. In addition to these captures, Mr. A. A. Eaton writes me of two taken at Seabrook, on the coast, at about the same time. Outside of New Hampshire, Messrs. Faxon and Hoffunann (:oo, p. 53) record a specimen killed Nor. 30 , 1899, on Onota Lake, Berkshire Co., Massachusetts, and also give two other records for the bird in the connty for previous years; Mr. R. O. Morris (: 02, p. 6) took one at Springfield, Mass.. Nov. 30, I899, and states that during the last five or six years the bird has occurred at that place a number of times; one was also taken in I90I. Mr. H. S. Hathaway (: oo) records a specimen taken at Point Judith, R. I., Nov. 26, I899, and adds that he had seen "six recently" (i. e., before Dec. I9, 'y9) taken off the Rhode Island coast. Finally, Mr. H. B. Bigelow tells me that he shot a single bird of this species on Nov. 29, 1899, at Broad Water Bay, Virginia. Evidently there was a large migration of Brunnich's Murres about the last of November, I899, extending so far soutliward as Virginia, and in the conrse of this migration a number of the birds on an overland flight seem to have becone exhansted and constrained to seek the ground, alighting wherever they might, at various 
points over southern New Hampsline and western Massaclu. setts. Apparently there was no meteorological disturbance at this time of sufficient severity to have forced the birds inland, and we are obliged to look for another cxplanation of this phe11onenal flight. May it not be that a general migration of the Murres along the Nova Scotia shores liad taken place at this time, and in their southward flight the birds liad followed the trend of the coast of Maine, and on reaching southern Maine, a number of then, instead of turning to skirt about the out-jutting coast of Cape Ann and eastern Massaclusetts, had continued straiglit on in their southwesterly course, and so have crossed southern New Hampshire and reached the Connecticut Valley, down which sone may have continued, and so reached the ocean waters off New York? A glance at the map shows that if a straight course parallel to the Maine coast were thus followed, it would lead necessarily over the route indicated. We may suppose that those birds which were found to have come to earth at the various localities mentioned, were eitler exhausted or bewildered, or had reached the end of a first stage of migratory flight. Mr. R. H. Howe, Junior, further contributes the interesting fact that on November 30, I90I, Mr. H. T. WVinchester observed numbers of small flocks of Murres on Newfound Lake, about Ioo birds in all. At sundown they began " peeping," each flock to flock, and gradually gathered on some rocks along the south sliore of the lake. They were very wary, and with some difficulty Mr. WVinchester shot two, one of which is in the nounted collection of Camp Pasquaney at Bridgewater, Future observations n11ay show that this cross-cut is not seldom taken by these birds on their southward flight.

\section{Plantus impennis (Limn.). GrFAT AUK.}

In former times this bird doubtless occurred on our sliores, and is mentioned by Belknap in I 792 as the "Penguin."

\section{Nlle alle (I,in11.). DOVEKIE.}

A not unconmon winter visitant off the coast; inland, it is of casual occurrence, being driven in by storms. 'Thus, specimens have been obtained at Concord, where after a severe storm, one 
was slot late in the year, some time since; Milford, where, as Mr. J. P. Melzer writes me, five or six which had been blown inland, were obtained some twenty years ago ; Warren, a specimen is recorded by Mr. Ned Dearboril ('98, p. 5) as having been taken at this place.

11. Stercorarius parasiticus (Lin11.). PARASITIC JAEGER.

A risitant off the coast in [spring], late summer and fall. Mr. A. A. Eaton has a specimen taken at Seabrook, September 2,1897 , and writes that it is "quite common during September."

\section{Rissa tridactyla (Linn.). KITTIWAKE.}

A common winter resident off the coast.

\section{Larus glaucus Brunn. Giaucous Guld.}

A rare winter visitant. Mr. William Brewster kindly contributes a record of a bird shot at Hampton, and which came into the possession of Mr. N. Vickary, the late taxidermist, about Feb. 20, I 886.

14. Larus marinus Linn. GRFAT BLACK-BACKED GULI.

A common winter resident on tlie coast.

\section{Larus argentatus Brumn. HERRING GUI, .}

A common spring and fall migrant and winter resident along the coast, and occasional inland, where after a hard blow, stray birds are seen on the large lakes, as at Chocoma Lake (Bolles, '93b, p. I 29) ; Concord, one seen April 7, I889, after a southerly gale ("P. C.', '89, p. 275) ; Dublin Lake, noted in small flocks in the fall, by Mr. G. H. Thayer (in literis); East Tilton, one seen at Little Bay in October, 1896, and another recorded from Webster I ake by Mr. Ned Dearborn ('9S, p. 5); Newfound Lake, two seen on September 3, rgor, and another at Squam Lake o11 Sept. 6, 1902, by Mr. R. H. Howe, Junior. These birds often follow up the larger rivers to a considerable distance inland. Thus on Fieb. 10, 1900, I saw two so far up the Merrimack as Nashua Junction, soaring about over the iver, which 
was frozen except in places where the current was rapid. Mrs. Celia 'Thaxter ('7O, p. 2II) in writing of the sea birds in summer at the Isles of Shoals, mentions that " the little yellow gulls, just ont of the egg, ran tumbling about annong the stones,' and it is not mulikely that they formerly bred there.

Noto: Lalles delawarensis Ord. RING-BILLED GULr.

Mrs. F. Fe Webster (:oob) has recorded as of this species a bird captured at Campton Village in November, 1898 . I am informed, howerer, that the identification is in doubt, and the species is therefore without a positive record for the state, though it should unquestionably occur on the coast.

18. Larus philadelphia (Ord). BONAPARTE's GUlr.

A spring and fall migrant and rare winter resident on the coast, where it is probably more common than the few observations might seem to indicate; occasional inland on the larger bodies of water. Records are at hand from the following localities: Charlestown, where an immature bird was taken on the Connecticut by Mr. W. M. Buswell, August 3, I897; Milford, single birds several times taken, as Mr. J. P. Melzer writes me; Plymouth, a flock of about Ioo birds noted in May, 1877, by "H. B. E.'" ('77, p. 345) ; Portsmouth, a male is in the Bryant collection, Mus. Comp. Zool., taken Oct. 20, I885; Ry'e Beach, Mr. William Brewster tells me that he found it common during migration in late summer; Scabrook, Mr. A. A. Eaton writes me of a specimen which he mounted Feb. I5, I890; Sunapee Lake, Dr. W. H. Fox writes me that an immature bird was shot in August, I880; Webster, Mr. C. F. Goodhue writes me of two taken on a pond, one about 1890 , the other during the last of August, I897.

Dates: May; August 3 to October 2o. Winter.

\section{1\%. Sterua hirundo Limn. Common TERN.}

A spring and fall migrant, and formerly a summer resident on the coast, where Mrs. Celia Thaxter ('7o, p. 2 I I) records that they used to breed on Duck Island anong the Isles of Shoals. She mentions that the natives called them " medrakes." The "tee-arr or fishing gull, Sterma minuta," mentioned by Belknap ( I792, I I , p. I69) may also have been 
this species. Individuals are of occasional occurence inland, on the larger lakes; thus at Winnepesaukee, Mr. C. F. Goodhue saw a pair on June 10, 1878 , at Forty Islands, and at Ossipee Lake, Frank Bolles ('93b, p. I29) records one shot Aug. 3o, ISgo.

\section{Sterna dongalli Montag. ROSHATE TERN.}

Formerly a stmmer resident at the Isles of Shoals (Baird, Brewer and Ridgway, '84, vol. 2, p. 305).

\section{Sterna fuliginosa Gmel. SoOTY THRN.}

An accidental visitant from the south. There is but one valid record, that of Dearborn $(98$, p. 5) really referring to the Black Tern, vi\%: at Ncwmarket, where "a fine adnlt male, taken . . . about September 14, is78, by Mr. D. C. Wiggin," is recorded by Mr. Ruthven Deane ('78b, p. 195).

\section{æ\{). Hydrochelidon nigra surinamensis (Gmel.).} BIACK TERN.

An occasional summer and fall migrant to the coast; casual inland. The following are the only actual records for the state which have come to my notice: Chocorua, one remained half a day on a small lake, September 30, I889, according to Frank Bolles ('93b, p. 129). T'his was probably the bird mentioned in the same work (p. 36 ) as seen on "one bright October morning "; Lake Winncpesaukce, one was seen June 10, 1878, by Mir. C. F. Goodhne. Mr. Goodhue writes me that through a lapsus on his part, this bird was given as Sterna fuliginosa in Dearborn's list ('98, p. 5). Nerifound Lake, an immature bird was shot by Mr. H. 'T. Winchester, on September 9, 1902, and is now in the collection of Camp Pasquaney, as I am informed by Mr. R. H. Howe, Junior. Ryc Bcach, Mr. Willian Brewster records (' $8 \mathrm{I}$ b) that a flock of about forty of these bircls was seen August 24, I880, by Mr. H. M. Spelman. The birds stayed several days about a small pond of brackish water, and four were collected. Mr. Brewster also examined a specimen shot here on Sept. I, IS6S. 
OV ARTS AND SCIENCES.

叉1. Estrelata hasitata (Kuhl). Brack-CAPPED PETRFI.

An accidental straggler from the sonth Atlantic. A single specimenl was captured at Pittsfield, in Merrinack County, in August, I S93, and beyond an anonymous paragraph in the Boston Sunday Herald ('93), appears not to have been recorded. The bird is now in the monnted collection of Mr. William Brewster, No. 46,076, catalogued under date of August 30, r893. Doubtless the bird was blown up the coast by the tropical hurricane of the last week of August in that year. A second specimen was taken on the same date, and "two days after the storm," at Blacksburg, Montgonery County, Va., about 200 miles from the coast, as recorded on p. $36 \mathrm{I}$ of volume $\mathrm{X}$ of the Auk.

22:. Oceanodroma lencorhoa Vieill.). Itach's PeTREL .

A common stmminer and attumn visitant off the coast, and of casual occurrence inland, where it has been captured at Alstead, a single specimen, September 29, I897, now in the mounted collection at the Acworth Public Library; Lancaster, two seen and one of then shot, October I, I897, on a snuall pond, by Mr. F. B. Spaulding ('98a, p. 50); Manchester, one shot near the milldam at Lake Massabesic, October 4, IS99, according to Mr. F. W. Batchelder (:00, p. 123).

2:3. Oceanites oceanicus (Kuhi). WIISON'S PETREI.

A common summer visitant off the coast. Mr. William Brewster (' 83 b, p. 402) has recorded them as being numerous offshore between Cape Ann and Cape Sable in Ju11e, I88I, and also informs me that he found them in great abundance between Portsmouth and the Isles of Shoals on July I I, 1874 .

24. Sula bassana (Linu.). Gannet.

A spring and fall migrant off the coast.

25. Phalacrocorax dilophus (Swains.). DoubleCRESTED CORMORANT.

A spring and fall migrant on the coast. Casual inland, where 
it has been taken on the Connecticut at Hartland, Vt., in October, I897, as recorded by Mr. R. H. Howe, Junior (:02, errata).

P. carbo doubtless occurs on the coast, but 110 definite records are at hand.

?6. Pelecanus erythrorhynchos Gmel. AMERICAN White PEIICAN.

The only record for this species in the state is that of Belknap (I792, III, p. I68) who affirms that it has been seen in New Hampshire. Doubtless in his time the bird was more likely to wander to New England than now, when it is but of accidental occurrence.

2\%. Merganser americanus (Cass.). AMERICAN MERGANSER.

A rather common spring and fall migrant and less common winter resident in onr inland waters; a not uncommon summer resident about the ponds and streams from the White Mountain region northward. At Intervale, in the Saco valley, I have observed partly grown young swimming in the river so early as June $23 \mathrm{~d}$. They appeared unable or at least unwilling to fly, and when suddenly friglitened, would skim, rapidly over the surface, the swiftly moving wings serving only to partially lift the body from the water. Later in the summer, during August and September, flocks of as many as a dozen are occasionally seen. In feeding they delight to work their way up stream along the shores of some rock-strewn river, half swimming, half wading, now splashing frantically to one side in pursuit of an escaping minnow, or, with head and neck submerged, ploughing straight ahead, exploring as they go. Ever alert, however, on the intimation of danger they stop, and swim slowly away, but if actually alarmed, all turn about and, half flying, half paddling, beat a precipitate retreat down stream often not stopping until they have gone lialf a mile or more. Both Mr. C. J. Maynard ('72) and Mr. William Brewster (:00) note it as breeding at Iake Umbagog. In Norember, as observed by Mr. Ned Dearborn (' $98, p .5$ ) they appear in numbers on the lakes 
in the sonthern part of the state, and many winter on the rivers where open water is to be found. Mr. R. H. Howe, Junior, ('99, p. 40) has recorded a single bird at Shelburne, on the Androscoggin River, so late as December 20, 1897, but I do not know of the birds wintering north of Iake Winnepesaukee. Mr. Dearborn finds then wintering on the Winnepesankee and Merrimack Rivers. Dr. IV. H. Fox writes me of a pair noted at Hollis, on our southern border, in July, 1876 , and it is not impossible that they may have bred in the neighboring region.

Dates: (Southern N. H.) November I to April I5 (July); (Northern N. H.) April to November (Deeember).

¿8. Merganser serrator (I IIn.). RED-BREASTED MERGANSER.

A common spring and fall migrant and winter resident on the coast; occasional inland. Mr. G. H. 'Thayer writes me that it is an irregular fall visitant to Dublin Pond.

Dates: November to April.

29. Lophodytes cucullatus (Linn.). HoOdis MisRGANSEK .

An uncomnion spring and fall migrant, and in the northern parts of the state, a summer resident. 'Tlirly years ago, according to Mr. C. J. Maynard ('72) it bred "not uncommonly" at Iake Umbagog, and Mr. William Brewster (:00, p. 208) states that it still breeds there in hollow trees.

Dates : March to November.

\section{Anas boschas Linn. MALLARD.}

A rare spring and fall migrant. Mr. F. B. Spanlding writes nie that one was shot on a pond near Lancaster in the spring of I 888 or ' 89 . Mr. Ned Dearborn ('98, p. 6) states that he knew of but three to have been shot in fifteen years on the Winnipesaukee River, the last one being in October, r895. In November, I900, there seems to have been a flight of Mallards in southern New England, and Mr. W. E. Cram writes me that on the Sth of that month he observed a flock of eiglit at Hampton Falls, two or three birds on the 9th, and five on the inth, of which two. an old drake and a duck, were shot. Mr. H. C. Sargent 
also obtained a male and a female at Enliot Pond near Chocorua on Norember 9, 1900, from a flock of about 10, and states that the bird seemed to be $u n k n o w n$ to the residents there.

\section{Anas obscula Gmel. BLACK Duck.}

A common spring and fall migrant and in the southern part of the state a rare summer resident, though breeding not nucommonly in the more northern areas. According to Mr. William Brewster (:02) it still breeds plentifully at Lake Umbagog. In the country about Intervale, although a few birds are to he found here and there throughout the summer, it is not unt the last of August that they appear in any numbers. Near Monadnock, Mr. G. H. Thayer has found it a rare summer resident. During September and October flocks of from six to thirty are found about the rivers and large ponds, and on the wind-swept lakes nutil early November.

Dites: Narch to December.

3:. Anas obscula rubripes Brewster. RED-LEGGED BLACK DUCK.

A spring (?) and late fall migrant. This newly described duck is stated by Mr. Brewster (:02) to be common in migration at Lake Unbagog from the second week of October nutil the waters are closed by ice, the earliest date of its capture there in fall being September 28, 1899 . Mr. C. H. Goodlutie has in his mounted collection a specimen of this duck taken late in the fall, years ago, at Webster. It doubtless occurs also in spring, but I know of no records.

Dat!es: (Spring?); (Septem1er 2S) October 8 to December.

33. Mareca anelicana (Gmel). Ambican WidgkON.

An uncommon spring and fall migrant on the coast.

Inates: April; September to October,

34. Nettion calolinemsis (Gmel.). GRHEN-WINGHD 'TEAI.

An uncommon spring and fall migrant. In the Connecticut valley, both Mr. F. B. Spatcling at Laucaster and Mr. W. M. lsuswell at Charlestown note its occurrence. In the central 
part of the state it appears to be rare. Mr. WV. E. Cram reports it on the coast at Iampton Falls.

\section{Querquedula discors (Linn.). B1,UN-WINGAD} TEAL.

An uncommon spring and fall migrant. I have records of this bird from the Connecticut valley and from the rivers and lakes of the southern and central parts of the state as well as from the coast, but in the White Mountain region it appears to be rare, and I have never seen specimens from there.

Dates: May; August 22 to November.

\section{Spatula clypeata (Linn.). SHOVELLER.}

A rery rare migrant. The only record is of two "shot at Rue Beach in August, 1872" (Baird, Brewer \& Ridgway, '84, 1. 528$)$.

\section{3\%. Aix sponsa (Linn.). Wood Duck.}

A not uncommon spring and fall migrant and occasional summer resident. Formerly it bred rather commonly throughout the well watered portions of the state. 'Thus, Mr. C. J. May'nard records it in 1872 as breeding about Lake Umbagog, and Mr. C. F. Goodhute found it a common summer resident at Webster at about the same time. At present it still breeds in small numbers at suitable localities; thus Mr. Dearborn ('98) instances a pair which bred near Tilton in 1892 and in 1893 ; Mr. G. H. Thayer writes that it is a regular summer resident at one spot near Dublin. Frank Bolles ('93b) found it to breed about Chocorua, and to the north of the White Mountains it must still be found in small numbers in summer. At Intervale, I have usually seen only single birds in fall, on the small meadow brooks, but on the lakes and ponds of this region flocks of six to a dozen are not infrequent during migrations, remaining into the first week of November.

Dates: March to Deecmber.

35. Aythya marila (Linn.). American SCAUP Duck.

An uncommon migrant in fall along the coast, and occasional inland. A few nust occur on the coast in spring, but I have 
no records. Mr. C. F. Goodhue writes me that he has once taken it at Webster, and has mounted a specimen shot at Concord about Dec. I3, I 899

39. Aythya affinis (Eyt.). Lesser SCAup Duck.

A rare migrant. Mr. C. F. Goodhne has obtained it near Webster and Mr. G. H. Thayer writes that he has observed it in fall at Dublin Pond.

40. Aythya collaris (Donov.). Ring-NeCKED Duck.

A very rare migrant. The only record at present available is that of a specimen obtained at Concord, during the last of November, a number of years ago, by Mr. C. F. Goodlue in whose mounted collection the specimen now is.

\section{Clangula clangula americana (Bonap.). AnER-} ICAN GOLDEN-EYE.

A common spring and fall migrant and winter resident along the coast and on certain of the larger lakes and streans inland in the southern part of the state; a summer resident at Lake Umbagog. Mr. William Brewster (:oo) has given an interesting and valuable account of the breeding habits of this bird as observed by him at Umbagog, where, he states, it still nests abundantly "especially about the outlet and throughout the bottom lands of the lower Megalloway River, where the forests were killed half a century ago by the back water from the dam at Errol." The birds remain on the lake into November, during which month, according to Mr. Ned. Dearborn ('98, p. 7) they first appear as migrants on the lakes in the southern part of the state "finally descending into the rivers when the larger bodies of water are frozen over." Many of these birds, he states, winter on the Winnipesankee and Merrimack rivers. Mr. G. H. Thayer writes that it is an irregular fall visitant to Dublin Pond. There is a single male specimen in the collection of the Acworth Public I,ibrary labeled as taken at Charlestown on the Connecticut River, June $13,1885$.

Dates: Summer; October to April 15 (June 13 ).

4\%. Charitonetta albeola (L,inn.). BUFr,

An uncommon spring and fall migrant on the coast; occasion- 
al inland, as at Webster where Mr. C. F. Goodlute lias obtained it.

Dates: March and April; October and November.

\section{Marelda hyemalis (I,in11.). OI,D-SQUAW.}

A connuon spring and fall nigrant and winter resident along the coast, and occasional also inland. In the Connecticut valley, this duck appears to be of not infrequent occurrence in migrations. Mr. W. M. Buswell includes it in a list of birds seen about Charlestown, probably on the strength of two speciniens, a male and a fentale, taken in Marlow, an adjoining town, on April 24, I $8 S_{3}$, and $110 \mathrm{w}$ in the collection of the Acworth Public Library. Mr. G. H. Thayer also writes me that it is an irregular fall visitant to Dublin Pond, sometimes occurring in large flocks. Mr. R. H. Howe, Junior, ( : O2) also instances two birds obtained at Windsor, V't., farther up the Connecticut. Mr. C. F. Goodhue writes of two taken late in November, about IS9I, on the Winnipesankee River, between Franklin Falls and Tilton. Mrs. Celia 'Thaxter ('7o) states that the fisherwen at Isles of Shoals call these birds "Scoldenores."

Dates: October to April 24.

44. Histrionicus histrionicus (Linn.). HARLEQUIN DUCK.

A rare visitor to the coast in late fall and early winter. Belknap (1792, III, p. I68) nentions it without comnent anong other New Hampshire birds, and it may have been of more frequent occurrence in his time. Mrs. Celia Thaxter ('70, p. 2 IO) also mentions it anong the winter sea fowl at the Isles of Shoals. The only definite record, however, is that given by Mr. H. A. Purdie (' 73 ) of a bird taken at Hambton, in Novenlber, 1872 .

45. Somateria dresseri Sharpe. AMrRICAN EIIDR.

A not uncomnon spring and fall migrant and winter resident off the coast. This is the bird conmonly known as "Sea Duck."

46. Oidemia americana Swains. AMERICAN SCOTIR. An uncommon spring and fall migrant and winter resident 
along the coast, and not rare as a migrant in the Connecticut river basin. Mr. William Brewster tells me that off the coast at Rye Beach, scattering birds, no doubt barren, are seen occasionally in summer. In the collection of the Acworth Public I, ibrary there are three specimens taken at Alstead, one a male, Oct. 8, r 883 , and two females on the 26 th of the same month. At Lancaster, farther up the valley, Mr. F. B. Spaulding writes me that on Oct. I2, I 894 , two gunners brought in four, 3 males and I female, shot from a flock of 8 on Martin Meadow Pond. Mr. R. H. Howe, Junior, (:02, p. Io) also adduces a specinen from the Connecticut at Windsor, Vt. Mr. G. H. Thayer finds the bird a rather regular migrant in fall at Dublin Pond, and notes that the greater proportion of the birds are males.

Dates: October 8 to April; summer (barren birds).

\section{4\%. Oidlemia deglandi Bonap. WhIte-WINGE SCO- TER .}

A common spring and fall migrant and winter resident on the coast; occasional inland on migrations as at Webster, where it has been noted by Mr. C. F. Goodhue, and Dublin Pond, where Mr. G. H. Thayer assures me it occurs in the fall with the other Scoters. Scattering birds occur off the coast in sumner, as noted under the preceding species.

\section{Oidemia perspicillata (Linn.). SURF SCOTER.}

An uncommon spring and fall migrant and winter resident on the coast; rare inland. Occasional specimens are also observed off the coast in summer, these being doubtless barrell birds. There is a female in the Acworth Public Library collection, without date, taken at Lempster in the Connecticut valley. Mr. G. H. 'Thayer states that it occurs in fall on Dublin Pond, but is less often seen than the other two species.

49. Erismatura jamaicensis (Gmel.). Rudny Duck.

An nncommon spring and fall migrant, and occasional also in stmminer, though its breeding in the state is yet to be established. 'There are two summer records for the soutliern part of the state: Nerefound Lake, where on July ir, 1901, a fine adult male was shot by' Mr. R. H. Howe, Junior, ('or, p. 27) and is now in 
the collection of ('amp I'aspluaney, Bridgewater; Ry' I'cach, where, as recorded by Mr. G. S. Miller, Jr.. ('or, p. IIs), an adult female in worn breeding plumage was taken on Angust 22, I879. 'The bird is in the collection of Mr. William Brem'ster. Although the latter specimen inay liave becil an early migrant, Mr. Miller is inclined to think that it luad not cone from any great distance, as lie liad found an adnlt fenale still accompanied by young in Massachusetts on Ang. I I, I 890.

Dates: Spring. July II ; August 22 to October $2 S$.

\section{Ђ(). Chen hyperborea (Pall.). I, EsSir Snow Goose.}

A rare and irregnlar fall migrant. In Belknap's time it nay have been more common and his " White Goose, Alias erythropus," (1792, III, p. I67) was probably this species. Mi. A. A. Eaton writes ne tliat a flock of six was seen at Seabrook in 1895 or ' $^{\prime} 96$, but the only actual capture of the bird that I can instance is of a young wale taken October 2, 1896, at Lake $\mathrm{C} / \mathrm{m}$ bagog, as recorded by Mr. Willian Brewster ('97) in whose possession the bird was stated to be.

\section{Chen caerulescens (Linn.). BLUE GOOSI:}

A casnal visitant from the interior. Belknap ( I792, III, p. I67) mentions the "Bluish Goose, Anas carulescens," withont comment in his list, but it is of conrse a question as to what this record may refer. The only antlientic record is at Lake Umbagog, where Mr. William Brewster ('97) states that an immature bird was taken on October 2, IS96, the specimen conning into his possession less than an hour after its deatl.

\section{5\%. Branta canadensis (I,inn.). CANADA GOOSE.}

A common spring and fall migrant. According to a writer in the Forest and Stream (vol. 22, p. 386) a pair was killed in the Merrinack river at Concord, on June 2, $18 S_{4}$, which, barring the possibility of these having been tane birds, is an 11111swally late date. During migrations flocks of these birds iot infrequently alight on ponds and lakes, in both spring and fall.

Dates: March II to April; October to December 7 .

5:3. Branta bernicla (Linn.). BRANT.

Althongh probably a not nucommon spring and fall migrant 
on the coast, it is only casual inland, the single record being that given by Mr. Ned Dearborn ('98, p. 8) on the authority of Mr. C. F. Goodhne, who writes ne that a bird was shot late in November about I89I, on the Vimipesaukee River between Franklin Falls and 'Tilton. The specimen is still in Mr. Goodhue's monnted collection.

\section{Olor columbianus (Ord). Whisturg SWAN.}

Years ago this bird was doubtless of regular and not uncon1mon occurrence, but it is now only accidental in nigrations. There is but a single definite record : at Seabrook, where according to Mr. William Brewster ('79a) a male in immature plumage was shot on October I 8, I878, by a gunner while lying off shore in a dory. Regarding the 'Trumpeter Swan, Olor buccinator, which is also believed to have formerly occurred in New England, it is interesting to recall the quaintly phrased statement of Belknap ( I 792, III, p. 166) that " naturalists have different opinions respecting the music of the swan. The tane swan of England is said to be silent; and Dr. Goldsmitl seems to think the accounts of the music of the wild swan fabulous. What is deemed fabulous in Europe, is often realized in Anerica. It is certain that our swan is heard to make a sound resembling that of a trumpet, both when in the water and on the wing." 'These remarks may very likely have had reference to Olor buccinator.

\section{5.). Plegadis autummalis (Hasselq.). Glossr InIs.}

An accidental visitant from the south. There is but a single record: Alton, near Lake Winnepesankee, "an old bird, in full plimage" taken in October, I $85^{8}$, by Dr. Charles Palmer, in whose collection it was said to liave been in 1872. 'The bird was first recorded by Dr. J. A. Allen ('69-'70, p. 637) and this record was later supplemented by Dr. Palmer ('7r, p. I20). Many writers on New England ornithology liave nentioned this specinen and it figures also in Mr. Dearborn's list ('98, p. 8'. This specimen was incorrectly recorded as " Wood Ibis (Tantalus loculator)"' in Forest and Stream (vol. 7, p. 3?5). 
56. Botaurus lentiginosus (Montag.). AnERICAN BITTERN.

A not uncommon simmer resident of the fresh-water marshes throughout the state. Its habit of breeding on the floating islands of grass at I ake Umbagog was described by Mr. C. J. Maynard ('72). In the Saco valley at Intervale, the bird is present in small numbers during late summer, keeping to the grass grown marshes and little brooks on the meadows. Mr. S. A. Shaw ('85) records a specimen obtained at Hampton, on December II, I88I, and states that one wing had been broken, but was entirely healed.

Dates: March to November (December II).

5\%. Ardetta exilis (Gmel.). LEAST BITTERN.

A rare summer resident in the extreme southern part of the state. This bird barely reaches our southern border, and finds the northern limit of its range well within the Transition zone. M1. C. F. Goodhue is quoted in Mr. Ned Dearborn's '98 list as saying that he is quite sure it has been taken at or near Bradford, and Mr. Dearborn also states that it has been reported from the vicinity of Hanover. This report is presumably that given in "A List of the Vertebrates fonnd within thirty miles of Hanover, N.H.," IS9I, a list which, though admirable in concept, 1nust unfortunately be used with some caution, and its statement that the Least Bittern is a "not rare summer resident" certainly should be carefully confirmed. The only trustworthy records that I have obtained for the bird in this state are: Hampton Beach, a specimen taken in $\mathrm{I} 869$, is in the mounted collection of the Boston Society of Natural History; Seabrook, where Mr. A. A. Eaton assures me he has seen a specimen killed in town. and in the possession of Mr. Isaac George. Samuels (' 67, p. 404) says that it has been found to breed in all the New England states, but I have found 110 actual breeding record for New Hampshire.

58. Ardea herodias Linn. Great BluE HERon.

A rather common spring and fall migrant and summer resident. Doubtless many of the individuals now seen in summer 
are not breeding birds, but formerly there were rookeries known in a number of places in the state. 'Thus Mr. C. F. Goodlune (' $77, \mathrm{p} . \mathrm{I}_{4} 6$ ) records the bird as having bred at Webster prior to 1877 , and Samuels ('67, p. 402) tells of a heronry in a hemlnck swamp at Frrol, on a small branch of the Androscoggin, where nests with partly grown young were found about June 25th. Still more recently Mr. Edward A. Preble writes me of a small colony which bred i 5 years ago at a spot annong the Ossipee Hills, two miles northwest of Dan Hole Pond. " Upwards of 100 nests were occupied within an area of about an acre. These were placed mostly in large beeches, one of which held 6 or 8 nests." 'The birds fished at Dan Hole Pond, where they obtained pickerel. A gang of sawmill hands broke up the colony in I 888. Mr. Ned Dearborn ('98, p. 9) adduces a recent instance from Belknap and Merrimack Cos., where a pair nested "in an old growth of pine situated in a large swanp. 'The young ones were supplied with food from a pond nearly two miles away." My friend, Mr. H. C. Sargent, also writes 11e that on May 26, I90I, he discovered a small rookery about a mile and a lialf east of Chocorua, on a slope near two ponds. The young birds were apparently hatched, and about a dozen nests were observed. In the White monntains a few of these birds usually appear in the Saco valley, singly or rarely in pairs, about the first of August, and often the sane birds seem to stay about in one locality for a number of days, feeding along the brooks and ponds. Doubtless there are secluded spots where they yet breed anong the White nominains, and after the young are off they seek the valleys for a season, where food is easily accessible. Individuals are apt to be scen in suitable localities throughout the state during all the summer 1uontlss. Occasionally one or two birds seem to linger late in the season as long as there is food and open water to be found. 'TIus Mr. H. C. Sargent writes me of a bird which was shot by a resident near Clocorua on December 2I, I900. 'The man fonnd the bircl in his yard, standing in eighteen inclies of snow, when he first went out in the morning. Mr. V. D. L,owe observed one at Randolpli on December 3I, I901.

Dates: $A$ pril 5 to November 6 (December 3 I). 


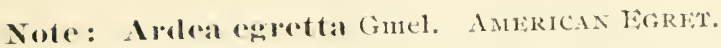

Bulknap (1792, III, p. 169) nentions a White IIeron anong the birds of the state, and Mrs. I:. Li. Webster recently writes me of a bird observed on May 18, 1901, at Franklin lialls. "feeding on a wet neadow bordering the Merrinack River," which must have been an Figret. It was seen by several persons and remained in the vicinity two or three days. An nnequivocal instance of its occurrence in the state is yet to be cited, however.

59). Ardeal caerulea I,inn. LITTLE BLUE HJRON.

An accidental visitant from the south. The only record is of a bird killed in Amherst, April 28, r 897 . It was brought to Mr. Janes P. Melzer, who states ('97) that it was "in perfect plunage, with naroon neck.',

\section{(io. Ardea virescens Linn. GREFN HERON.}

A not nucommon summer resident about the lakes and water courses of the southern part of the state, becoming rarer in the central regions. It is a bird of the Transition zone, and seems to occur regularly about as far northward in New Hampshire as do the white oaks. Mr. E. A. Preble informs me that he has observed it occasionally in summer at Ossipee along the Beech River, but it appears not to occur farther up in the region, as Frank Bolles did not mention it from Chocorna, nor liave I any knowledge of its presence at Intervale, in the Saco valley. 'The bird is also apparently quite absent from the Franconia region, though doubtless a few do work up the Connecticut valley to about this latitude. Mr. F. B. Spaulding of Lancaster writes me that on June 6, I897, while near the Connecticut at that place, in company with Judge J. N. Clark, a bird flew uver which the latter gentleman pronounced to be "unmistakably a green heron." Mr. Spaulding had never met with the bird there previously. Farther south, along the Connecticut in the vicinity of Walpole, I have found the bird not nncommon, and it is rather common at Newfound Lake (Howe, : o , p. 27).

Dates: Last of April to October,

61. Nycticorax nyeticorax novius (Bodd.). BLACKCROWNED NIGHT HERON.

A not uncommon summer resident near the coast, but less 
common inland. It appears to penetrate the interior of the state by following up the water ways even to the foot of the White Mountains. At Dublin Lake, Mr. G. H. 'Thayer writes me that it is an irregular visitant, not knoyn to breerl. In the Merrimack valley, Mr. C. F. Goodhue has found it rarely near Webster, and still farther up, it has been recorded from Newfound Lake in summer (Howe, : or, p. 27). A number appear to work up the Saco valley through Maine, and thus reach the White Mountain region. At Chocorua, Frank Bolles ('93a, pp. $36 \&$ 128) states that a few are found late in summer and instances a flock of ten which remained for two or three days in the neigliborhood, one August. At Intervale, I have seen and heard occasional birds on the Saco meadows in the months of June, July and August and have attributed to these birds the two or three large stick nests which I have found nearly every year high up in some large white maples by the water's edge, though doubtless the young, if such there had been, were already grown by the time I arrived (late June). In the Connecticut valley, neither Mr. W. M. Buswell of Charlestown, nor Mr. F. B. Spaulding, of Lancaster, have met with the bircl, though doubtless a few do penetrate so far up perhaps as the latter station, and Mr. R. H. Howe, Junior (:02, p. I I) gives it as occurring in the Connecticut valley at Windsor, Vt., and at St. Johnsbury farther north in that state. Certain it is, however, that over the greater part of central, western, and northern New Hampshire it is absent.

Dates: April to October.

62. Grus mexicana (Mul1.). Sandhi, Crans.

This bird is supposed to have occurred as a migrant in New England at the time of the first settlement of the conntry. Sereral of the early writers on this region mention what seem to have been cranes, and among them Belknap (1792, III, p. 169) lists the "Crane, Ardea canadensis," as of the birds occurring in New Hannshire. 'The only actual record for the state appears to be Wakefield at Lovell's Pond, where Mr. William Brewster (: or) states that he is informed by Mr. Ned Dearborn, a specimen was obtained in 1896 or 1897 . Mr. Dearborn first 
saw the specinen at the shop of Mr. J. S. 'Turner, a taxider ninst at Portsnouth, to whom it had been sent in the flesh in a fresh condition. Mr. Dearborn has purchased the specimen and it is now preserved at the State Agricultural College at Durham. The presence of the bird in the state is of course quite fortuitous at this time.

\section{(i:3. Rallus virginianus Iinn. Virginia RaIL.}

A local summer resident of the Transition regions, and perliaps not so rare as the few records might seem to show. The following are the only instances which have come to my notice: Hamplon, a bird seen and its nest, containing eight eggs, found May 2S, I887, and another bird found dead under some telegraph wires by Mr. S. Albert Shaw ('s7); Hampton Falls, Mr. W. E. Cram gives it as a summer resident; Hollis, Dr. W. H. Fox writes that it is a rare summer resident; Marloze, there is a specimen in the Acworth Public Library, taken October I, ISSI; Lancaster, Mr. F. B. Spaulding writes me that several years ago a boy found a nest containing about ten eggs on a low meadow near the Connecticut, and that Capt. B. F. Goss identified the eggs as of this species. This is the only record I have obtained for the northern part of the state. Webster, Mr. C. F. Goodhue has found it rarely and does not know of its breeding.

Dates: April to October I.

\section{Porzana carolina (Linn.). SorA.}

An uncommon and local snmmer resident in the Transition area. I have found it in summer in a certain sedgy bog at North Conway, and on July I3, I 897, at Intervale, I several times started a single bird from the short grass of a flooded hayfield on the Saco meadows during a sudden and extensive freshet. Doubtless the birds breed in the vicinity. What may have been an early migrant was seen at Intervale by a brook on the neadows, Angust 26, I898. Mr. W. E. Cram finds it in summer at Hanpton Falls. In migration Mr. William Brew. ster has fotnd it not uncommon in fall at Rye Beach.

Dates: May to October. 
65. Fulica americana Gmel. AMrRicin Coots.

A rather rare autumnal migrant, occurring in the Connecticut valley and in the lake region of the south-central part of the state.

Dates: September to October 8.

66. Crymophilus fulicarius (Linn.). RED PHAtAKOP's.

This species, like the next, is found in migration off the coast well out to sea, but occasionally inland, whither it is probably driven by storm. In May, I892, great numbers of Red and Northern Phalaropes were observed at various points along the New England coast, and among others at the Isles of Shoals, where, according to Mr. Bradford Torrey ('97, p. 392) thousands were observed by Mrs. Celia Thaxter, "in great flocks that wheel and turn, and, flying in long masses over the water, show now dark, now dazzling silver as they careen ". These flocks probably included the two species, as was the case elsewhere. Mrs. Thaxter had noted the birds the year before at the Isles of Shoals. Mr. F. B. Osgood records ('91, p. 9) having "put up a flock of a dozen or so in the middle of Lake Unibagug."

6r. Phalaropus lobatus (I,inn.). Nor'Tnekn PIIALAROPE.

An abundant spring and fall migrant offshore, casual inland. Mr. R. I. Brasher ('94) records meeting with " numerons flocks" some twenty miles off the New Hampshire coast, on August 9, 1893; they disappeared as land was sighted. Mr. IV. C. Prime ('89) has twice observed the bird in the Franconia Monntains. In the first instance, the single individual was not captured, but was observed at very close range in Septenber, about I884, as it swam on the waters of Profile Lake, feeding on the multitudes of winged ants drowned on the surface. 'The second instance was on Septenuber 22, 1888, when a single bird was knocked over with a short stick on I onesone Irake (about 3,000 feet altitude). It was quite fearless, and was feeding on the seeds of sedges which grew at the margin of the lake. 
'The great abundance of Phalaropes at the Isles of Shoals in May, 892, has been mentioned mider the preceding species.

Dalles: Mray; Aligust 9 to September 22.

6S. Steganopus tricolor Vieill. Wilson's PhalaROPF.

A rare migrant to the coast. Baird, Brewer and Ridgway ('s 4, p. 339) record the bird as "shot by Mr. William Brewster at Rye Beach in the stmmer of I872." I am informed by Mr. Brewster that the specimen in question was obtained on Ang. 1 5,1872 .

69). Philohela minor (Gmel.). American Woodcock.

A not uncommon spring and fall migrant and a less common summer resident throughout the lowlands of the more remote parts of the state. "WW. H. B." ('96) records an old bird with a brood of young seen by a Mr. Oliver Dodge "on the sonth slope of a hill in the town of Brookline, N. H.," on the I 3 th of March, several years previous, after a rather open winter. Such early breeding seems rather improbable, however. Mr. C'. J. Maynard ('72) records that they were found to breed, thongln not commonly, at Lake Umbagog, where a nest with four eggs was fonnd May Io, I87o. At Intervale, I have observed then not infrequently in summer among the alder swales about the brooks in the valley, and in September, a few are to be found in damp woorls up to 1,500 feet.

Ditatio: Last of March to October 17.

\%O. Gallinago delicata (Ord). Wirson's Snipk.

A migrant, uncommon in spring and more common in fall near the coast ; inland it is generally found only in small nunnbers, in marshy spots about ponds. At Intervale, in the Saco valley, I have never seen but a single bird, this on Sept. I8, I 897, in a small marsh. A writer in the Forest and Stream, signing himself " W. H. B." ('96) says he has known the bird to winter at Nashu1a, an occurrence which, though not inprobable, must be quite nuusual. Mr. William Brewster has observed it at Rye Beach on July 22.

Dates: March to May; July 22 to November (Winter?). 
61. Macrorhamphus griseus (Gmel.). Dowitcher.

A rather common fall migrant coastwise; a few probably occur in spring, but $I$ have no records.

Dates: July 20 to August 25.

ซ2. Micropalama himantopus (Bonap.). STI Ti SANDPIPER.

A rare fall migrant. The single classic record still remains the only published instance of the occurrence of the bird in this state: Rye Beach, "no less than ten specimens" were secured by Mr. William Brewster ('72, p. 309) in the Augusts of I868, 1869. 'These birds were first recorded in the American Naturalist, Vol. III, p. 639, and have been mentioned by many writers since that time. Mr. Brewster has kindly given me the dates of capture of eight specimens at Rye Beach, as follows: Aug. 20, I868, one shot; Ang. 24, I869, one shot; July 31, I871, one shot; Aug. 9, I87I, one shot; Aug. II, 187I, two shot; Aug. 24, I871, one shot; Aug. 25, I871, one shot.

Dates: July 3 r to August 25.

\%:. Tringa maculata Vieill. PECTORAL SANDPIPJiR.

A rather uncommon fall migrant inland about the marshes and larger bodies of water; common also as a coastwise migrant.

Dates: July to October io.

84. Tringa fuscicollis Vieill. WHITF-RUMPLD SAN1)PIPIER.

An uncommon migrant. Mr. William Brewster tells me that he found it not uncommon at Rye Beach in July and August in former years, while inland it has been taken at I ake Unbagrog, according to Mr. H. Merrill ('82) who records a specimen "shot about Oct. 2," and " two others upon Oct. 14," I 876 , by Mr. N. C. Brown.

\section{\%.). Tringa bairdii (Cones). BAIRD'S SANDPIPER.}

A rare fall migrant on the coast and at $I_{\text {rake }}$ Unbagog. The records are: Lake Umbagog, one obtained "on a mudflat at the foot" of the lake, Scpt. I, I875, by Mr. Willian Brewster 
('76a, 1), 19), and one shot on the mudfats at the month of Cambridge river, Sept. 4,1880 , and two others, a male and a female, at the sane place on the following day (Brewster, '81a, p. 6o) ; Rye Beach, two were shot on August 26, I880, by Mr. H. M. Spelman ('s, b). One of these birds was in company with "a large flock of peeps."

Dates: Angust 26 to September 5 .

\section{g6. 'Tringa minutilla Vicill. LAAST SANDPIPR.}

A very common migrant in spring, late summer and fall, on the coast, and to a less extent inland, where it occurs about the larger bodies of water. Mr. IF. W. Batchelder (:00, p. 125) records this bird at Mancliester, June 3 and July 10 , and asks thus if it may not be a summer resident; on the contrary, these dates probably represent the end of the spring nigration and the begining of the fall migration respectively.

Dates: Last week of May to June 3; July 10 to Septemler.

\section{\%\%. Tringa alpina pacifica (Cones), RAD-BACKLD} SANDPIPER.

An nnconnion migrant on the coast. A few shonld occur in spring, but my only records are in fall, when the bird is commoner.

:S. Eremetes pusillus (I,inm, ), SEMPALMATED SANDPIPER.

A very common spring and fall migrant coastwise, and also not uncommon in fall as a migrant along the shores of the larger bodies of water, as at Lake Umbagog (Brewster, $S_{\text {ra, }}$ p. $6 \mathrm{I}$ ), Dublin Lake ('Thayer, in litt.) and Ossipee Iake (Preble, in lit.)

Dates: May; July to September.

\section{Calidris arenaria (Linn.). SANDERLING.}

A common spring and fall migrant on the coast. Mr. William Brewster noted it as common at Rye Beach after August 2.

SO. Limosa fedoa (L,inn.). MARBIED GODWIT.

An accidental visitant. Mr. Willian Brewster permits me to 7 
record a speciuen slot at Rye Beach, Aug. 27, I868, by a local gunner. Mr. Brewster examined the specimen slortly after its deatl.

S1. Totamus melamolemcus (Gmel.). GREATER IELI,OW-I,EGS .

A common spring and fall migrant on the coast, but uncommon inland, where it is of occasional occurrence about the larger bodies of water and in the Connecticut valley. Mr. R. H. Howe, Junior ( : or , p. 27) records an eanly specinen at the head of Newfound I,ake, July I7, I901. Both Mr. F. B. Spanlding at Lancaster and Mr. WV. M. Buswell at Charlestown in the Connecticut river valley, find the bird occasionally on migrations, and Mr. G. H. Thayer writes me that it is not infrequent at Jublin Lake in fall.

Dates: Nay; July i 7 to October 7.

\section{$\mathbf{8}$. Totanus flavipes (Gmel.). JEI,LOW-I,EGS.}

An uncommon spring, and common fall migrant on the coast. Rather rare inland; Mr. C. J. Maynard ('72) gives it as " $110 t$ a common summer visitor' at Lake Umbagog, 30 years ago, and Mr. Ned Dearborn ('9s, p. Io) records a single bird observed Aug. 20, r889, at Alton.

8:3. Helodromas solitarius ( Wils.). SOLI'ARY SANDPIPER.

A common spring and fall migrant, and possibly a rare summer resident. No conclusive proof has yet appeared to show that the bird nests in the state, though Baird, in Baird, Brewer and Ridgway's “ Water Birds” ('S4, p. 282), says, “ Early in A ugust, r 878 , I noticed a pair of this species with a brood of four young hardly able to fly, near an open reservoir of rain water, on Appledore, Isles of Shoals. 'Ilhese were too young to have cone to that island over the water, the distance being nine miles; and that this brood conld have been hatched on that rocky and treeless island seems very improbable. 'T'lncy were in company with, yet holding aloof from, several pairs of Tringoides macularius [Actitis macularia]." Doubtless occasional barren birds remain about ponds throughout the breeding season in favored 
localities. 'Thus Mr. C. I'. Goodhue writes me of one which he observed in June, feeding abont a small pond near the sumnut of South Kearsarge Monntain, and Mr. G. II. Thayer writes that lie has repeatedly observed then in the breeding season on a sunall wood pond at an elevation of about 1,580 feet at the northeastern end of Mt. Monadnock. About the last of July the migrating bircls appear rather commonly along the waterways and poncls, and usually spend the day quietly feeding. During the last week of August, I 897. I several tines found as many as 13 or $1+$ birds congregated abont a small drain at Intervale, to feed, but when closely approached, they mould fly off one or two at a time in different directions. In early September, I have occasionally seen single individuals about the little lakes in Carter Notch, at 3,360 feet. Here they would remain all day, feeding along the shore, and pass on southward after clark, sometimes calling loudly as they departech. Occasionally, too, I have seen single birds in the latter part of a summer afternoon, with steady graceful fight, passing southward down the Saco valley. Mr. C. J. Maynard ('72) has noted a single bird at Errol, in the northern part of the state, so late as "Norember Ist, I 869 , when the ground was covered with snow and the ,ponds were partly frozen.",

Dites: May 9 to June: July i7 to November 1.

\section{Pavoncella pugnax (Limin.). RuFi.}

An accidenta! visitant from the old world. The bird is included here on the strength of a female obtained by Mr. Milliam Brewster ('76a) on September 8, 187f, while it was " flying on the marshes at the mouth of the Cambridge river," which is nearly on the boundary line between New Hampshire and Maine, at the southern end of Lake Umbagog.

85. Bartramia longicauda (Bechst.). BARTRMMIN SANDPIPER.

Formerly a connon summer resictent of the upland fields and pastures in the southern and central parts of the state, and a common spring and fall migrant. Of late years, however, it has become scarce or lias entirely disappeared from its old lo- 
calities. Mr. Ralph Hoffmann informs me that a few still suminer at Alstead, and Mr. G. H. Thayer writes that it breeds regularly but in small numbers in the northwestern corner of Cheshire Connty. Mr. C. F. Goodhue has also fonnd it breeding at Webster. North of Lake Winnipesankee, I have no record of its occurrence as a breeding bird. In the Howe-Shattuck collection there is a male (No. 1753) taken on its breeding grounds, July i 3, I 89 I, by Mr. W. H. Phelps at New London.

Dates: May to September.

86. Tryngites subruficollis (Vieill.). BUFF-BREASTED SANDPIPER.

A rare fall migrant on the coast. Baird, Brewer and Ridgway ('84, vol. I, p. 306) record its capture at Rye Beach hy Mr. IVilliam Brewster, who tells me that he slot one on eacli of the dates Aug. 25 and Aug. 28, I871.

8\%. Actitis macularia (Linn.). SPOTTED SANDPAPK.

A rather common summer resident, of general distribntion along the larger water courses and about the lakes and large ponds. Dr. A. P'. Chadbourne ('87, p. I03) records seeing a single bird on July S, I886, in the Great Gu1f, MIt. Washington, on the west branch of the Peabody river, at abont 3,100 feet altitude. It must be only exceptionally that this bird ever penetrates the forest brooks to this height. Mr. L. B. Spanlding records (' $98 \mathrm{~b}$ ) a nest containing the unusual number of five eggs, at Lancaster.

Ditles: May I to October.

88. Numenius longirostris Wils. I,ONG-1311,1:D CURI, FW.

A rare fall migrant 111 til recent years; now accidental. Mr. Wrilliam Brewster observed single birds at Rye Beach on Aug. 25, 1871, Attg. 12 and 17, 1872.

89. Numenims hudsomicus Lath. Hudsonan C'uritew.

An n11con1110n migrant. Mr. Willian Brewster noted it at Rye Beach in former years between August 6 and September 2. 


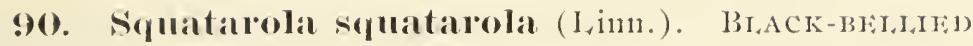
PIOYER.

A [spring] and fall ningrant on the coast. Mr. Willian Brewster noted it as ratler common in Angust, at Rye Beach, some years ago.

\section{Charadrius dominicus Mull. Amlicich GOLDEN} PlNFER.

A rare fall migrant. According to "Sanourai ', ('76, p. ro2) they appeared at Rye Beach in 1876 on September I4. Mr.. Willian Brewster tells me of four specimens noted at Rye Beach as follows: Aug. 26, IS68, two seen, one of which was shot; Aug. 29, 1868, one seen; Aug. 27, r87 r, one shot.

\section{9:2. Agialitis rocifera ( $\mathrm{L}$,im1.). KILDEER.}

Formerly a rare migrant. Mr. William Brewster observed onc at Rye Beach on Aug. 3r, r868, and two at the sante place on Ang. 4, r $87 \mathrm{I}$. 'Though probably still of occasional occurrence as a nigrant on the coast, the only other records which I have, are of its casual appearance. Thus in the midst of the great storm of November 25, I888, as writes Dr. A. P. Chadbourne ('S9, p. $25^{S}$ ), quoting a letter from Mrs. C'elia Thaxter, they appeared at the Isles of Shoals (as elsewhere along the New England coast) in great numbers. "After the storm the birds gradually disappeared, except a few that remained at favorable points for a long time." Mr. Bradford Torrey writes ('89, p. 275) that he was assured by Mrs. Thaxter that some of these birds remained at the Isles of Shoals until the last week of February, I889. A second accidental record is of a bird shot at fefferson, to the north of the White Mountains, in December, r 893 . Mr. F. B. Spaulding, to whom I an indebted for this record, states that the bird was in a very emaciated condition and evidently mable to proceed farther.

9:3. Agoialis semipalmala Bonap. SEMIPAMATED PLOVER.

A spring and fall migrant, common coastwise, but less connmon in fall on the sliores of the larger lakes and ponds. 


\section{Colinus virginianus (Lin1.). Bor-whitf.}

A rather rare permanent resident of the Transition valleys of southern New Hampshire. Owing to the great numbers of these birds which have been introduced into New England from the south in recent years, it is now impossible to say what proportion, if any, of those at present found, are native bred. That southern New Hampshire is a part of the bird's 11atural range, is evident, however, as that careful chronicler, Belknap ( I792, vol. III, p. 170) mentions it over a century ago, as a bird of New Hanpshire. Mr. C. F. Goodlue ('77a, p. I +6 ) also gives it as a rare resident at Webster in the ' 70 's. Our severe winters appear to keep the birds in check, notwithstanding the frequent restocking. The repeated failure of southern birds to survive the cold seasons is hardly to be wondered at, when even the native birds, inured by long years of natural selection to the northern clinate, can barely loold their own on our sonthern border. During the summer of 1899 . I thrice observed a single bird in the Saco valley at Intervale, thougl it is highly improbable that it was other than an introduced specinen which had been loosed in the neighboring region. I know of none having been observed in the locality before or since.

9.5. Canachites canadensis canace (I,inn.). CANADIAN SPRUCE Grouse.

A not unconmon permanent resident of the spruce and balsam forests of the upper Canadian region, in the northern part of the state, and along the higher peaks of the White Mountains. It occurs on the Presidential Range in snllall numbers and secms less connmon there than on the Carter-Morialn Range, where at least one or two are almost sure to be seen in a few hours' walk. On these monntains, it inhabits the rich, danp belt of balsams and spruces from about 3 , ooo fect (on the southern exposires) to the upper linit of the tree growth, at 4,800 to 5,00o feet. It also occurs in small numbers on the 'Twin Monntains, on Moosilauke $(4,8 \mathrm{IO} f t$ ) and on the ligher peaks of the ontlying Sandwich Range, as on Passaconaway ( $4,116 \mathrm{ft}$.) where it was recorded by Bolles ('93b, p. 155) "in the autumn," 
and on 'Tripyamid (4, Is ft.) where Mr. F. H. Allen saw two in June, I 894, and Mr. R. W. Gray one on Aug. 6, 1899; one was also seen by Mr. Allen on Mt. Osceola (4,352 ft.) in the early part of the summer of isgs. In the primeval forest of the I iast Brancli of the Penuigewasset, on Angust 4, I902, I observed a single lirel in a thick balsan swanp so low as 2,ooo feet, and another was secu the day previous at about 4 , , oo feet on a spur of Mt. Hancock. 'Tliere scems to be no movenent of these birds toward the valleys even in severe winter weather. Mr. C. J. Maynard ('72) speaks of the bird as comnlon thirty years ago at Lake Unbagog, where eggs were taken in the latter part

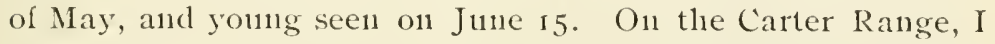
saw, on July 24, IS99, an adult female, in company with a young bird, lardly larger than a Bob-white, but able to fly readily. Two full grown young were seen together on the sante range, Sept. 14, 1900. The crop of a fine male shot on this range in I90I, was found to contain a quantity of balsan needles.

\section{D6. Bonasa umbellus togata (Linn.). CANAdian} RUFFE, GROUSF.

A rather conmon permanent resident of general distribution, being fonnd throughout all the wooded country from the 'Transition valleys to the upper linit of scruis growth on the White Mountains.

'Typical examples of $B$. umbellus umbellus apparently do not occur in New Hampshire. Birds from the southeastern portions of the state are usually more or less intermediate, but nearer togata. Speeimens which I have seen from the White Mountains seen quite typical of the nortlern bird, and as stated by Mr. William Brewster ('95, p. 406, foot-11ote) "the dark gray birds which inhabit the primitive coniferous forests of 11orthern Maine and New Hampshire and western Massachusetts are all 1early, or quite typical representatives of togata."

From year to year, their numbers are subject to more or less variation according as the season is favorable or not. Eintire broods remain together throughout the breeding season, and until well into the fall, wandering about in the woods, and becoming quite fat on a diet of various berries, leaves, and buds. 
In the crops of different birds I have found, in early fall, bits of leaves of Aspidium spinulosum, Populus grandidentata, and fruit of the snowberry (Chiogenes), blueberry (I'accinium) and white baneberry (Acta $\alpha$ ). The birds delight to wallow in fine, dry dust in sunny spots in the woods, and hence are often met with along trails, where the sun can reach and dry the ground. Mr. Vyron D. Lowe, of Randolph, writes me that while crossing the Presidential Range in the latter part of winter, in 1900 , he found two of these birds frozen to death, away up among the scrub, where, on account of the thick crust, they were unable to burrow into the snow at night. This fact is of interest as slowing that they migrate but little from these upper levels, even in the winter season.

9\%. Meleagris gallopavo fera (Vieill.). WiLD TurKEY.

Formerly a common permantent resident in the sonthern part of the state, but long since extirpated. Dr. Jeremy Belknap ( 7992 , vol. III, p. I70) writing of the birds of this state, says they "were formerly very numerous. In winter they frequented the sea shore, for the sake of picking small fishes and marine insects, which the tide leaves on the flats. ** * 'They are now retired to the inland mountainous conntry." Lidently the birds were nearly extirpated by the early part of the nineteenth century, though Dr. Samuel Cabot (' +4, p. So) states that he "purchased onc in the Boston Market, brought from New Hampshire," so late as 1841 or '42.

\section{Ectopistes migratorius (Lin11.). PASSENGER} PIGISON.

['ormerly a summer resident of great local abundance, but now practically extirpated.

Arriving within our borders during the first week of April in tremendons flocks, they nested in large colonies, at least as far 1north as the White Mountains proper. Ii. D. Sanborn, in his History of New Hampshire ('75, p. 159) states that at abont r 780 , in northern New Hampshire, the air was "black with flocks of pigeons, which were canght in inmense numbers, and their meat dried for winter use. The feathers were used 
for bedding." Mr. C. I*. Goodlue, of Webster, tells me that as a boy, some forty years ago, he remembers seeing great flocks of these birks flying northward in early spring, forming a solid phalanx, with a front of a rod or so broad. and extending to cither liorizon. 'They still bred at Webster according to Mr. Goodhne ('77a, p. I I3) in the '70's, and I am informed by an old inhabitant of the town of Conway that some forty years agro great numbers nested on the Rattlesnake Range of hills in that township. Dr. IV. H. Fox, writes me that they were formerly very conmon at Hollis in the southern part of the state. and used to be netted extensively in the '7o's; one nest was fonnd, and the last flock seen was in 1880 . There is a monnted specimen in the Public I,ibrary at Acworth, taken at that town, October IO, I $88 \mathrm{I}$, and is the most recent specinen from the state that I know of, though Mr. IV. IV. Flint, of Concord, writes we that the last Passenger Pigeon of which he has any recollection was shot near his house in the summer of 1885 , when the birds were already rare.

Dates: April 2 to October ro.

99. Zenaidura macroma (Linn.). MOURning Doré.

A not uncommon summer resickent of the Transition country in the southeastern part of the state, along the seacoast and especially in the botton lands of the Merrinack valley where it is fairly common about Concord and farther up at Franklin. On the coast, Mr. A. A. Eaton writes that it is quite common at Seabrook, nesting in slender pines, and Mr. W. E. Cram notes it as a summer bird at Hampton Falls. Dr. W. H. Fox says it was formerly rare at Hollis, but has since become commoner. In the western part of the state, the bird is only of occasional occurrence in the southern Connecticut valley, mhere a few probably work up from the south. 'Thus Mr. W. M. Buswell writes me of having several times seen a bird or two in the spring and early summer of 1898 , and again in April, i 899, at Charlestown. Beyond this, I liave no information of its presence in the Connecticut valley. Mr. F. H. Allen informs me of a single female seen about the last of June, I 894 , so far to the northward as Waterville, on the outskirts of the White Mountains. The bird 
was eridently a straggler, as the species appears not to occur regularly north of Lake Winnepesaukee.

Iates: I ast of Marcli to October.

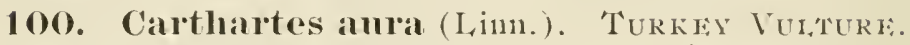

An accidental visitant from the sontl. It lias twice been captured in the state, as follows: at Hampton Falls, on the coast, where on the 6 th or 7 th of April, r8s2, a female was slot by Irank Percell. 'This specinen, which is preserved in the monnted collection of the Boston Society of Natural History, was recorded by $\mathrm{Mr}$. C. B. Cory ('S2). Mr. IVillian E. Cran, of Hampton Falls, also writes me that on the 15 th of May, 1898 , he saw a bird of this species at that town, and that, although he did not shoot it, he had sufficient opportunity to make the identification unquestionable. The second capture of the 'Turkey V'ulture in the state was at North IVeare, near Concord, where, as I am informed by Mr. C. M. Stark, a bircl was found one spring morning, about 1887 , by a Mr. Felch, in the latter's lien yard. It appeared unable to fly, and when thrown into the air wonld only flutter to the ground. It was kept for some time by Mr. Stark, and would often wander off to a considerable distance in the fields. I ater the bird was given away to a butcher, about whose slanghter louse it remained for sonse time and then suddenly disappeared.

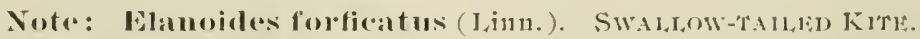

Mr. Ned Dearborn (' 98, p. 13 ) includes this species in his list of birds of Belknap and Merrimack Counties on the testimony of one Cro. Stolworthy, "who states that lie saw one in Franklin in 1875. It picked up a snake within one hundred feet from him, where he had a gool clance to see it." I)r. W. II. Iox also writes me that on July 4 , 1887 , a farmer, whom he considered reliable and who was a sportsman, reported to him "a large bird, thought to be a lawk, having a forked tail like a barn swallow. It was secn quite closely as it lit.on sone alders near the road and remained while he drove by." Though both these cases suggest the bird in question, the evidence does not secm to warrant its inclusion as a bird of the state.

\section{Cincus hudsomius (Linn.). MARSH HAWK.}

An unconninon local sumner resident, breeding in marsliy places. I liave never observed it in the breeding season anong 
the White Monntains, though it is rather common on the meadows of the Saco valley during the migration in August and September. At such times, a single bird will remain in the same neighborhood for sereral days at a time, evidently funding food plenty, and being in no haste to move sonthward:

Diltes: March 16 to November 12.

10:. Areipiter velox (Wils.). SHARP-SHINNEl) HAWK

A connuon spring and fall migrant, and a less common snmmer resident: in the southern half of the state, a winter resident. Throughout the hearily-wooded parts of New Hampshire, this hawk is of general distribution during the breeding season, occurring well wp onto the monntains. In the winter, a few are to be found in the lower part of the state, and Mr. C. F. Goodhue ('77a, p. 1 13) has recorded them in this season, about Webster. A northerly winter record for this bird is that of one obtained at 'Tamworth, on December 27, I898, by Mr. R. WV. Gray and now in the Howe-Sliattuck collection. 'Throughout the White Monntain region this is by far the commonest lawk during the fall nigration and especially in the months of August and September, when it is to be found, usually singly, from the fertile valley bottoms, through the woods, even to the summits of the monntains, and I have seen a single bird on the rocks near the summit of Mt. Washington, on the 28th of Angust, I9or. I have not infrequently heard from this bird, a sharp "chip," much like a I'hobe's "chip," and usually given when alarmed or as it starts to fly from the perch on which it may have just alighted.

10:3. Areipiter cooperii (Bonap. . CoOpé's HAWK.

A not uncommon spring and fall migrant and summer resident. It breeds regularly over the greater part of the state. and thronghont the lower Canadian region, up to about 3,000 feet on the higher mountains.

Intes: March 26 to October.

101. Accipiter atricapillus ( Wils.). AMERICAN GOSIIAWK.

An irregular, though sometimes common visitant in late fall 
and winter; rare summer resident. From the White Mountains northward the bird is probably a regular breeder, and Mr. F. B. Spaulding writes that he has found its nest and eggs on the banks of the Connecticut river on the Vermont side opposite Lancaster. South of the White Mountain region, it has been recorded by Mr. Ned Dearborn ('98, p. 14) as haying bred at Dumbarton. where, in 1897 , a female was shot on her nest, and sent to Mr. Thomas R. Payson, of Northfield, in whose possession the skin now is. Mr. Ralph Hoffmann (:03) writes that on July 21,1902 , he discovered a nest of this species at Alstead, in the southwestern part of the state. It contained two young, nearly full grown, which were already taking short flights by the ?gth of July. One of these young birds was shot, and is now in the collection of Mr. WVillian Brewster, of Cambridge, Mass. The nest was placed in a small pine, at a height of thirty-five or forty feet. The migrating birds appear in fall in the lower part of the state about the last of October, and Mr. IV. F. Cram, of Hampton Falls, writes me of having seen it there so late in the spring as March ro.

Dates: October 25 to Miarch ro; Summer.

105. Buteo borealis (Gmel.). RED-TÁlin Hawk.

An uncommon, though generally distributed permanent resident of the lower Canadian region, breeding in the well wooded upland and mountainous districts. There is a slight migratory novenent on the part of many of these birds, so that they are resident in winter in the southern parts of the state at localities from which they are generally absent in summer. 'They winter so far north at least as the southern valleys of the White Moun$\mathrm{t}^{\text {ains. }}$

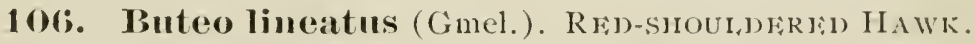

An uncommon permanent resident of general distribution at the lower altitudes throughout the wooded areas of the sonthern and central parts of the state. The bird is apparently rare so far up as the White Mountains. Mr. I*. M. Spaulding omits it from a list of birds secn by hin at I ancaster, and I have never positively identified it but once at Intervale, where on 
Angust 25, 1SyS, an inmuature bird was shot in the Saco valley. On one or two other occasions, howerer, I an confident that I have observed it there in the nuonth of August. At Chocorma, Frank Bolles ('93b p. 100 ) records it in August, and it doubtless breeds in that vicinity.

\section{0\%. Buteo platypterus (Vieill.). BRoAn-WINGED} HWK.

A fairly common summer resident of the dense nixed woods of the sub-Canadian area. In the White Mountain region and northward, it is the commonest breeding liawk, but in central and sonthern New Hampsline it is less common except along the ridge of the western part of the state. Dr. W. H. Fox writes me that years ago he found a nest and young at Ilollis on the southeastern border. Mr. G. H. Thayer finds it not nuconnmon about Monadnock, and I have seen it in sunnuer along the range of hills west of Newfonnd Lake, where, however, it is rare. In the White Mountains it breeds in the woods up to the linit of large tree growth, about 2,500 feet. Like many of the hawks, it slows attachment for a chosen locality, and I have known of a pair at Intervale which nested for several seasons in a large beech tree in the forest. 'The nest was a huge pile of sticks in a crotch of the tree, and evidently the accunulation of years. Portions of two or three dead garter suakes were found in the nest, which at the time of my visit on July 22, 1898 , contained two young birds ready to fly.

l)ates: April to September 15.

108. Archibuteo lagopus sancti-johannis (Gmel.). AMERICAN ROUGH-LEGGED HAWK.

An tunconnuon fall and winter visitant, sometimes occurring in flights of considerable 11 mbers. Mr. C. F'. Goodhue ('S5) mentions it in a list of birds observed in winter at W'ebster. and states that one specimen in black plumage was taken. Mr. Ned Dearborn ('98, p. I5) says that he is informed by a Mr. Henry Osgood of Pittsfield, of a large number that " passed in loose flocks over Catanount Mountain in this town one day late in November, a few years ago. He also lias a mounted speci- 
men in melanistic plumage that was killed in his vicinity." On the coast, it also occurs in small numbers, and Mr. WV. IE. Cram of Hampton Falls, who has observed the bird frequently, writes me that he had a good opportmity to watcl a pair at his town so late as the 5 th and 6 th of $\mathrm{May}, 1895$. Headds that they were evidently male and female, both in rather dark plumage, and that he might readily have killed both, but preferred not to.

Dates: October to (May 6).

\section{Aquila chrysatos (I,inn.). Golden EAgra.}

A permanent resident, now become extrenely rare and irregular. There appear to be no recent records of the breeding of this bird in New Hampshire, though formerly a few nested regularly in inaccessible localities annong the White Mountains. As recorded by Baird, Brewer and Ridgway ('7t, rol. III, p. 3r6) a pair nested for years on the inaccessible Fagle cliff, at Profile Lake among the Ir ranconia Mountains. Repeated efforts were made to reach this" nest, but in vain. "In the summer of I 855 a renewed attempt was made to scale the precipice orer which the shelving rock, on which the nest stands, projects. A party was formed, and although they succeeded in ascending the monntain, which was never achieved before, they could reacli only a point beyond and above, not the nest itself. * * * 'The party reported a large collection of bones in its immediate vicinity, witl other evidences of the accmulated plunder of many years, as well as a plentiful supply of fresh food at the time visited.' Nuttall ('32, vol. I, p. 64) mentious tluat lie saw a young bird which had been brought from the White Mountains, where it had been taken from its nest in the montlu of August. The last breeding record for the state appears to be that of C. A. Hawes (' 78 ) who states that on July 6,1876 , lie observed at White Horse Ledge, Nortl Comway, a nest containing two young, partly fledged. He made an unsuccessful attempt to reacl the shelf of rock on which the nest was placed, but managed to get sufficiently near to see that the nest itself was about four feet across, and built of large sticks, while all about were scattered featliers, fur and bones. On visiting the locality the following year, lie found that the birds were no longer there. 
Both H. I). Minot ('77) and Mr. Wn. Brewster ('95) nnention laving seen the bird soaring high orer the smmmit of Mt. I,afayette. The only recent captures of this eagle in the state are: Bartlett, one canght in a fox trap on Feb. 19, 1893, recorded by "Jagare", ('9.3) ; Hollis, Dr. IV. H. I'ox informs we that one was sliot eiglit miles west of this town on Sept. I6, I8S I $N c w^{\prime}$ Hampshire, Mr. Ralph Hoffmann writes me that he examined a nownted specimen in the slop) of $\mathrm{WV}$. E. Balcli, a taxidermist at L,nenburg, Vt., and which was said to have been taken in the state. Mr. Balch, on my inquiry, tells me that it was sent to him on Oct. 9, I 899 , from New Hampshire.

1 10. Haliacetus leucocephalus (I,iun.). BALD EAGI,i.

An uncommon snmmer resident in the central and northern parts of the state, and occasional at all seasons in the sontheasterin section. It is generally to be found during the sinnuner in small numbers about the larger lakes, as at Umbagog, where, however, Mr. Wm. Brewster ('95, 1. 386) does not believe it now nests. Mr. Ned Dearborn ('9S, p. 15) finds the bird also along the shores of Lake Winnipesaukee and the river that drains it, and makes the interesting observation that " they usw1ally roost in the same place as long as they remain in a single locality, and if there are several in the neighborhood, they generally assemble at nightfall to spend the night together." Toubtless these are not breeding birds. At Newfonnd Iake, however, is a fine pair of old birds, which probably nests on the nomntains near, and returns yearly to the lake to smm1ner; indeed, the residents say that there has not been a su1nn1er for generations, that has not seen a pair of the big birds sailing over these waters. Mr. Vyron D. L,owe, of Randolph, a keen woodsina11, tells nue that a pair of Bald Eagles has s11nnered for perhaps 25 years on the Presidential Range of the White Mountains, and that nutil seven years ago, or thereabonts, the nest was nearly at timber line on MIt. Adanis, but that some one robbed it, and the birds have left the site, thongh he still sees them on the range at intervals during the smmmer; in I902, Mr. Iowe first saw the birds on March 23d. On the coast, a few birds winter, and a specinen is recorded in the Or- 
nithologist and Oologist ('S2) captured at Portsmouth, Jan. 27, I882; Mr. F. H. Allen also saw one on Feb. 2, I90o, from the cars while passing through the southeastern part of the state. Mr. W. F. Cram has observed it the year round at Hampton Falls. Inland, the first migrants appear early in March, and I am informed of a fine adult bird seen by Mrs. E. E. Webster at Franklin Falls, not far south of Lake Winnipesankee on March 3, I900, there being still two feet of snow on the ground.

\section{Note: Falco islandus Brunn. White GrRfilcon.}

Mr. C. J. Maynard ('72) states that he saw what he is certain was a bird of this species, flying higl above hin1 as he was crossing a 111011 tain pass in Errol, on Nov. 5th, 1868 . While the cliances are in favor of the bird having been a Gyrfalcon, the identification cannot be considered sufficiently positive to warrant inclusion in this list.

111. Falco rusticolus olsoletus (Grmel.). B ВАск GYRFALCON.

A very rare winter visitant. There is but a single record, near Milford, one shot in January, isyr. The bird was originally recorded by Mr. J. P. Melzer ('9r) as from Milford, V't., which, as he informs me, was a mistake. It was taken on Lyndeboro Mountain, a range of hills which runs through the towns adjoining Milford, N. H. Mr. Wm. Brewster ('95, p. 480) records the locality correctly.

\section{1\%. Falco peregrinus anatum (Bonap.). Duck} HAWK.

An uncommon local stmmer resident. A number of places are known to which a pair of these birds has returned year after year to nest on the same cliff, a notable instance being the pair at Fagle Cliff in the Franconia Mountains which appears to have held possession for a number of years succeeding the desertion of the site by the Golden Eagles. Mr. Ned Dearborn $(' 98, p .16)$ mentions a place near Alexandria where the birds were reported to be seen, and young in the latter part of the summer. At Humphrey's Ledge, a high 'cliff rising from the Saco valley at Intervale, a pair has bred for several years. 'T'he old birds are noisy during the early part of the summer, and 
often are seen soaring high over the river, more like a Buteo than a Falco, and uttering their loud, squealing cries. After the young leave the nest, gravity brings then down to the valley bottom, but they are soon able to fly sufficiently well to keep out of gunshot. The whole fanily ustally disappears soon after the young are strong on the wing, and I liave not observed then about their ledge after Ang. I5th. Mr. G. H. Thayer writes me that he usually finds one or two every summer on the higher ridges of MIt. Monadnock, but does not know of their breeding. On the coast, Mr. W. E. Cran notes the bird at Hampton Falls as a migrant in the months of March and April, September and October.

\section{Falco columbarius Limn. PIGEON HAWK.}

A rather rare spring and fall migrant. Dr. A. P. Chadbourne ('87, p. IO3) records that one was "seen' in the Great Guif, Mt. Washington, at about 3,00o feet, on July 8, i 886. The bird was not secured, however, so that the record does not certainly establish the bird's presence in New Hampshire during the breeding season. I have never found it in the fall migrations anong the White Monntains, when other hawks are common, and all the many specimens seen or shot liave been of other species. Mr. C. F. Goodhue has taken the bird at Webster, however. Amateur local lists of birds usually include this species as a summer resident, where doubtless the Sharpshinned Hawk is the bird in question.

\section{Falco sparverius Limil. American Sparrow} HAWK.

An unconnuon spring and fall migrant and a rather rare summer resident of the Transition areas of the state, breeding sparingly in the valley bottons well up towards the bases of the White Mountains. At Intervale, I have known of bit a single pair to nest in the vicinity during ten years' observation; this pair bred for one or two seasons in a large dead tree on the Saco valley neadows, about eight years since. A few appear also in late snmmer in the nigration down the valley. I have seen 
there on August 25, I897, a sulall family group of three birds, which may have come from no great distance. The fall migrants appear at Intervale during the last week of August and occasional birds are seen through the first half of September. They cross the mountain ranges in migration and two liave been noted by Dr. A. P. Cliadbourne ('87, p. Iot) flying low over the summit of Mt. Clay, of the Presidential Range, on Sept. 2, I $8 s_{4}$, and "the next day another came sailing down from above and disappeared in Tuckerman's Ravine." Mr. Bradford Torrey also saw one fly close by the summit of Mt. Washington $(6,290$ feet $)$ about the 28 th of August. I9or.

Diltes: March is to October.

1 15. Pandion haliactus canolinensis (Gmel.). AMERICAN OSPREY.

A rather common spring and fall nigrant along the coast and on the larger streams and lakes; also a rare summer resident. According to Mr. C. J. Maynard ('72), they used to breed at Lake Umbagog. In the fall migration, they appear with more or less regularity during the last week of August about the lakes and streams. Dr. A. P. Chadbourne ('87, p. IO4) has recorded one which flew a few yards over his head on MIt. Jefferson, Sept. 2 , i 884 , elevation about $5,500 \mathrm{ft}$. As with other hawks, they appear often to cross these high ranges, instead of kecping altogether to the valleys.

Dates: April: Summer; August 25 to November I.

116. Asio wilsonianms (I,ess.). AMFrican I gong1:AREN OWI.

A rather rare resident. All the records which I have for this species are from localities in the southern and central part of the state. I have nerer seen it in the White Monntains.

11\%. Asionacipitrinus (Pall.). SHORT-IARED OWI.

Rare, occurring o:1ly as a migrant so far as known. Mr. C. F. Coodhue has found it very rarely at Webster, and Mr. J. P. Mel\%er writes me that he las mounted perhaps twenty specimens killed in recent years about Milford.

la:tes: a pril; Novenber. 


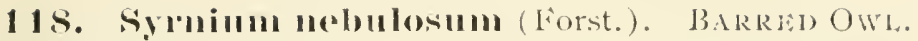

A permanent resident thronghont the woxded region of the state, and without doubt onr commonest owl. In the White Mountains, where other species of owls seen generally rare, it is fairly common and of general distribution throughout the sub-Canadian woodlands up to about 3,00o feet. I'rank Bolles' account ('90) of his pet Barred Owls taken from the rest at Chocorna, on June 1, I 888 , contains nucl of value and interest. He found these Owls much given to sumning themselves sleepily during the morning hours, and often, while in the woods, could call up a bird by initating its notes. Although donbtless this is a strictly resident species, one always is more apt to see them in fall than at other times. 'There is probably' some slight migratory movement, as the young birds move off, or the older birds change station occasionally.

119. Scotiaptex cinerar (Gmel.). Great Gray Ow.

A rare winter visitant. Mr. G. H. Thayer writes me that there is a monnted specimen in the possession of a farmer at Chesham, which was taken sone years ago in late autumn, in the heavy moods to the northwest of Mt. Monadnock. Mr. James P. Melzer writes that he has had two or three brought in for mounting in years past, from about Milford. My friend, Mr. V. D. Lowe, of Randolpl, has also described to me an owl taken in late September, I892, on the Dead Diamond River, a branch of the Megalloway, in Wentwortl's Location, which can hardly be other than this species. Mr. Lowe is acquainted with the common owls, and I have no reason to doubt that the bird in question was a Great Gray Owl.

1 ?o. Nyctala tengmalni richardsoni (Bonap.). RicnARDSON'S OWI.

A rare winter visitant from the north. 'The definite records for the state appear to be the following: Chocoma, my friend, Mr. H. C. Sargent, permits me to record a specimen which he shot there March 1, I900, just after an winswally heavy snow storn1 ; Comish, Mr. R. H. Howe, Junior (:02, "Errata") records a specinen taken " in the autumu or early winter about 
I 890," and in the collection of Mrs. Russell Brewster, of Windsor, Vt.; Hollis, Dr. W. H. Fox ('83) records a female shot on Dec. 15, I879. The weather was mild at the time, and there were about three inclies of snow on the ground; Milford, Mr. J. P. Melzer writes that he has mounted two or three killed in the vicinity during the last twenty-five years; Webster, Mr. C. F. Goodhue has monnted a specimen taken here, a number of years ago.

Dates: December i5 to March 1 .

121. Nyctala acadica (Gmel.). SAW-WHET OWL.

A resiclent throughont the state. of general distribution, but apparently nowhere common. At Hampton Falls, on the coast, Mr. W. E. Cram finds it the year round; at Hollis, Dr. W. H. Fox saw one in June, I875, and states that it is rather common there in autumn. Mr. C. F. Goodhue has found it to breed rarely at Webster, and Mr. Ned Dearborn ('98) considers that in point of numbers it comes next to the Barred Owl in Belknap and Merrinack Connties. In the White Monntain region, it is occasional in stummer; Frank Bolles ('9o, p. I I3) records a single bird at Chocorua on July i 8, i 889 (?); and Mr. F. H. Allen observed one late in June, I 888, at Campton. Mr. V. D. Lowe, of Randolph, tells me also that he has sometimes heard it in stummer on Mt. Adans, about "Perch Camp," 4,400 feet, shightly below the tree linit. At Lancaster, in the upper Connecticut valley, Mr. F. B. Spanlding ('93) has found it nesting on several occasions.

\section{Megascops asio (Linn.). Scrmiach OWL.}

An uncommon permanent resident of the Transition regions of the state, following the valley bottons well up into the White Mountains, where, however, it becomes rather rare. Mr. C. I'. Goodhue finds it at Webster, and it is occasional throughout the soutli-central parts of the state, as at Acworth, Cliarlestown, Hollis, Keene, Newfound I ake and Peterborough. I'arther north, in the central part of New Hampshire, Mr. E. A. Preble writes me that it is fairly common abont Ossipee, and yet farther, a pair or two are found nearly every summer at Intervale. 
Here they are confined to the river valley, and I know of a pair which nests annually in a large grove of sugar maples by the Saco River, and one or more of the family are often to be found here throughout the summer. On June 18 , 1900, I found the brood of four young hardly out of the nest, all sitting erect and notionless side by side on a maple branch, while one of the old birds, in great excitement, flew from tree to tree with weird cries of protest. Mr. F. B. Spaulding writes me that at Lancaster, in the upper Connecticut valley, he has seen it but a few times, and never found it to breed.

1:3. Bubo virginianus (Gmel.). GREAT Hornen OWl.

A rather common resident throughout the well watered forest areas of the state, but apparently rare in the White Mountains themselves. Mr. G. H. Thayer writes me that it is present in small numbers about Mt. Monaduock; Mr. C. F. Goodhue has often had specimens from abont Webster, and north of the White Mountains it is not uncommon about the larger lakes and streanns.

\section{Nyctea nyctea (Linn.). Snowy OwL.}

An irregular late fall and winter visitant, sometimes occurring in considerable numbers along the sea coast; accidental in summer. Mr. L. J. Rundlett ('97) has recorded a "full-grown, adult Snowy Owl," shot on the intervale near Concord, July i 5, 1897. The previous week had been extremely hot, and the bird is conjectured to have lived in a large ice-house near by, upon the cupola of which it was shot. The sex of the specinen was not determined. Mr. Rundlett informs me that it had been seen a few days previous by some workmen, and that just before it was killed, it had been started from the tall grass, where it may have been searching for mice. This occurrence is, of course, purely accidental. Mr. C. F. Goodhue ('77b) has recorded a specimen killed at Webster so early in the fall as just previous to Oct. Iо, I877. Mr. Ned Dearborn ('98, p. I7) adduces three records for Belknap and Merrimack Counties, and Mr. H. L. Piper informs me of having taken the bird in winter near Rindge; it is not infrequent throughout the Con- 
necticut valley in winter, and at Colcbrook, a Mr. Norton ('S 3 ) records three secured in the flight of $188_{3}-84$. There was a considerable flight along the coast during the winter of $1901-02$, and several were killed near Portsmouth. In the White Mountains, I have only very rarely known of their presence in winter. Mrs. Celia 'Thaxter ('7o, p. 209) speaks of this owl as a frequent winter visitant to the Isles of Shoals, where it feeds largely upon the numerons rats on the islands. "Sereral snowy owls," she writes, "hannt the islands the whole winter long. I have never heard them cry like other owls; when disturbed or angry, they make a sound like a watchman's rattle, very loud and harsh, or they whistle with intense shrilness, like a human being.",

Dates: (October 10) November 3 to March 4 ; (July I5).

1:5. Sutuia ulula caparoch (Mull.). AdERICAN HAWK OWI.

A rare and irregular visitant in late fall and winter. During the late fall of I $88_{4}$, an unusual flight of these birds occurred over northern New England, of which Mr. Willian Brewster ('s5) has given an account. During this flight, the birds were noted commonly at Colebrook, and four were sliot at Lake Unbagog. The records for the state, so far as known to me; are as follows: Colcbrook, during the flight mentioned above, Mr. Ned Norton found them common here, and writes ('s 8 b) under date of December I : "I,ess than one incl of snow now. Hawk Owls came three weeks ago in greater numbers than ever before. Farmers' sons have been killing then all over the conntry." The same observer states that on April 20, I884 ('S fa), he observed a Hawk Owd near Colcbrook with a nouse in its claws. Lake Umbagog, four were secured by Mr. William Brewster ('85) dluring the I884 flight, on the dates October 25, October 31, November 15 and November 16 respectively. Mcriden, a specimen in the monnted collection of the Boston Society of Natural History is labeled as having come from near tiis town. Milford, two specimens from this vicinity have been mounted by Mr. J. P. Melzer in years past. N'ashua, one was taken by a Mr. O. H. Plillips, formerly a taxidermist, near this 
place in the late ' 70 's or early ' 80 's, as I am informed by Dr. IV. H. Fox. who examined the specinen. Penacook, Mr. C'. I. Goodlute has mounted one shot here some years ago, and has a mounted specinen shot by lim about thirty years ago at $\mathrm{l} / \mathrm{c} b$ ster, where he also shot another bird at about the same tine. Mr. Ned Dearborn ('98, p. 18) states that a Mr. George Stolworthy asserts that he mounted one taken in Sanbornton during the breeding season, an occurrence which, if true, is surely quite accidental.

Dates: October 25 to April 20.

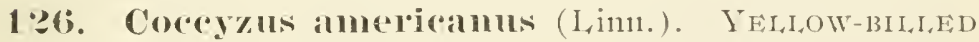
Cuckoo.

A very rare summer resident, barely reaching the sonth-central parts of the state in the Transition areas of the valley bottoms and the coast. A few of these birds appear to follow up the Merrimack valley for some distance, and perhaps with more regularity. than the few recurds might seem to indicate. Thus Mr. WT. W. Flint writes me of one killed a few years ago at Concord, and seen by hin, and Mr. Ned Dearborn ('98, p. Is) records a pair seen in a piece of inundated woods at Northfield, farther up the valley, on June 24, I897, and adds that another was brought in which was found dead, that sane season. It is stated by Mr. F. W. Batclielder (:00, p. 127) to be a "rare summer resident" at Manchester, thougl 110 definite instances of its occurrence are cited. The most northern record for the state is that given by Mr. R. H. Howe, Junior, (:OI, p. 35) of an adult temale shot on July + , igoo, at the head of Newfound Lake. The lird may very well have followed up the Merrinack and Pemigewasset valley's to this point. The same author $(: \mathrm{O} 2)$ records its presence in the Connecticut basin of Vermont, and I an assured by Mr. W. M. Buswell that it occurs at Charlestown, N. K.., in the Connecticut valley. On the coast, IIr. A. A. Eaton writes me that he has positively identified it at Seabrook, and Mr. W. E. Cram has noted it thrice at Hampton Falls, September, 1897, September, 1899, and August, I900, respectively. 
1\%\%. Coccyzus erythrophthahmus (IVils.). BLACKBILLEE CUCKOO.

A common summer resident of the Transition regions of the state, penetrating the valleys and foot hills of both sides of the White Mountains, where it is found not infrequently in the sub-Canadian woods up to at least I, ooo feet. Mr. F. H. Allen has found it quite common at Jefferson and Randolph and it doubtless occurs throughout the open valley lands of the region to the north of these mountains.

Dates: May 12 to Angust 29.

\section{1:S. Ceryle alcyon (Linn.). BELTED KINGFISHER.}

A summer resident, of general distribution about the larger streams, lakes, and ponds ; rarely it winters in the southern and central parts of the state. Baird, Brewer and Ridgway (' 74 , vol. 2, p. 395) record a single pair which had a nest in a bank by the side of the carriage road on Mount Washington, " more than a mile from any water. It was a shallow excavation, made that season, and contained fresh eggs the latter part of May. The food of the pair was taken near the dam of a sawmill on Peabody River." The altitude at which this pair bred must have been about 2,500 to 3,000 feet. After the breeding season the birds often make considerable wanderings into the region about their nesting site. At such times they will often follow the tront brooks through the woods, and in mid-September, I liave found them occasionally to reach so high an altitude as 3,360 feet, at the lakelets in Carter Notch. Mr. Ned Dearborn (' 98 , p. I8) states that one wintered on the Suncook river in I88990 , and that he has seen at least one at Tilton in mid-winter.

Date's : varch to November 24; (Winter).

129. Dryobates villosus ( I inm.). HAIRY WOODPECKER.

A not uncommon permanent resident, confined during the breeding season to the Canadian areas. It breeds on the higher land from the southwestern portions of the state northward, and in central New Hampshire is rather common. In the White Mountains I have found it commonest on the larger ranges from 3,000 to 4,500 fcet where there is an abundance of birch, fir, and 
spruce. In winter, there is a slight movement sonthward, and into the valleys"from these upper regions.

\section{Dryobates pubescens medianus (Swans.).}

DOWNY WOODPECKER.

A common permanent resident throughont the Transition and sub-Canadian life zones, up to about 3,000 feet on the mountains, though occasional birds go still higher into the small tree growth, and on Ang. I, 1899, I observed one in 'Tuckerman's Ravine, Mt. Washington, at over 4 ,ooo feet aning the balsams. In winter there seem to be nearly as many of these birds on the mountains as in summer, but those which I have observed at this season have all been below 3,00o feet.

131. Picoides arcticus (Swains.). Arctic Thren-TOED WOODPECKER.

A rather rare permanent resident of the upper Canadian regions of the White Mountains and the northern part of the state; occasional also in fall and winter in the southern part of the state. In summer, its range is practically that of the following species in the White Mountains, but it seens less common. Dr. A. P. Chadbourne did not observe it during his White Momntain trips and I have seen it only on two occasions, these while on a trip over the Carter-Moriah range, in early September, I90 I. Frank Bolles ('93b, p. I55) attests its presence on Mt. Passaconaway in summer, and H. D. Minot ('77) records that he has found the nest in the White Mountains. F. A. Bates ('9r) records two nests with young in late June from the mountain forests at the head waters of the Pemigewasset. Dr. Walter Faxon also tells me that he saw a bird of this species on Mount Moosilauke on October 4, several years ago. Farther south, Dr. A. L. Reagh has observed two birds at Newfonnd Lake, on August 18, 1899. W. B. O. Peabody ('4I p. 338) states that he is informed by Dr. Brewer that it breeds at Keene, but while an ontlying pair may have bred on the northern slope of Mt. Monadnock, it certainly has not since been found to breed so far south, though Mr. G. H. Thayer (:02) records a female observed on May 18, I899, at Chesham, 
six miles north of that peak. 'To the north of the I'hite Iountains, the bird is a resident of the coniferons forests. In fall and winter there is often a fairly well defined morement of the birds into the White Monntain valleys and over the coutlern part of the state. Thus Mr. C. C. Shattuck saw 3 or $t$ during the last week of December, I899, at the Albany Intervales, and another at the same place on Feb. 1s, s901. Mr. Ned Dearborn ('gs, p. I9) records a female seen at Alton on Dec. 20,1890 , and implies that he has known of others taken in winter in the southern part of the state: Mr. C. F. Goodhuc ( 77, p. 96) has found it a very rare fall and winter visitant at Webster; Dr. Charles Palmer ('71) has recorded a specimen taken late in fall at Strafford; at Hampton Falls, the bird lias been observed in fall by Mr. IV. E. Cram, and Mr. A. A. Eaton writes me of one shot at Seabrook in November, I888, and a second specimen killed at the same place on Nor. 26, 1 S99.

\section{1:3:3. Picoides amelicanus Brelnu. AMFrICAN THRJis-}

TOED WOODPECKER.

An uncommon permanent resident of the upper Canadian zone in the White Mountains and in the upper part of the state. In winter, there is a slight movement into the valleys, and rarely into the southern part of the state. Thus Mr. G. C. Shattuck has seen a single bird on each of the dates Dec. 31, I900, and Feb. I4, Igor, at the Albany Intervales, the valley west of the Moat Mountains and north of the Sandwich range, and on Bear Mountain of the latter range, I'rank Bolles ('93b, p. 247) has recorded seeing a pair on Dec. 2 I, 189 I, apparently about half way up the mountain. Mr. C. I*. Goodlute ('85, 1. It) has taken a single bird at Welster in Jannary, I875. Ontlue White Mountains themselves, whether by cluance or otherwise, I hare found this the commoner of the two three-toed woodpeckers. It occurs in summer in the rich, dannp, balsan forests from 3,000 feet (or slightly less where cold streams flow off on the northern slopes) to f,oon fect. Mr. Willian Brewster has taken two adult males at Corham, July 30,3870 , and Mr. C'. J. Maynard lias seen one in August by the road not far from the Glen House (Brewster, ed.. '95, p. 333). IOr. A. 1'. Clat- 
bourne ('87, p. IOf) has recorded an adult fenale and a young bird below Hermit I,ake in 'Tuckerman's Ravine (3,960 feet) and another in the Great Gulf on Mt. Washington, July 5, 1886. On the Carter Range, in the latter part of summuer I have a few times met with the bird, and on I)ecember 27, 1900, one was seen among the large trees in Carter Notcl just above the lakes, at about 3,400 feet, on the sonthern slope of Carter Done. There were about 18 inches of snow on the ground at that tine, but evidently the bird was as much at lome at this high level in winter as in summer. Frank Bolles ('93b, p. 155) notes having observed both kinds of three-toed woodpeckers in summer, among the dense spruce forests which clothe the top of Mt. Passaconaway (4, I $6 \mathrm{ft}$.), which appears to be the southermmost New Hampshire record for this species in summer. To the north of the White Monntains in the dense evergreen forests, it is a rare resident, and Mr. William Brewster ('98a) has given an excellent account of a pair at Lake Unbagog, whose nest, containing a partial complement of two eggs, was found on June 2, I 897.

1:3:3. Sphylapicus varius (Limm.). YEILOW-BFit,IED SAPSUCKER.

A fairly common spring and fall migrant, and a less common summer resident. To the north of the White Mountains, about Lake Unbagog and in the saturated forests of the northern regions of the state, it is a common! smmmer bird; in the White Monntains, too, it is not infrequent in the damp, sub-Canadian woods of paper and yellow birch, spruce, balsam, and hemlock below 3,00o feet, but seems rather local, and becomes still more local south of the mountains, being confined more or less to cold swamps during May and June. Thus at Intervale, it is rare; and on only a few occasions liave I observed it in the woods on the immediately surrounding low monntains. Frank Bolles found it common at Cliocorna, and I have also noted several birds in a farorable swamp near his cottage. In the central parts of the state it is also found here and there in summer, as at Bridgewater, Wonalancet, Ossipee, Webster. Mr. Ralph Hoffmann has observed a few in a swamp at Alstead in the 
sonthwestern part of the state, and Mr. G. H. Thayer writes me that about Mt. Monadnock it is a regular summer resident in the lieary timber about the base of the mountain. At Charlestown, Mr. W. M. Buswell writes me that he saw a female Sapsucker on Nov. I0, I898, and that it was seen there every few days until Jan. 5, I899, when he shot it to make sure of its identity. Its wintering so far north is probably quite accidental. It is now believed that the specimen recorded by Baird, Brewer and Ridgway ('74, vol. II, p. 543) as $S . \approx$. nuchalis, taken by Mr. Wllliam Brewster near Lake.Umbagog in New Hampshire, was merely an inclividual variation of the eastern bird.

Dates: April to Octoler 20 (winter).

134. Ceophloeus pileatus abieticola Bangs. Nok'tiERN PILEATED WOODPFCKER.

A rather rare permanent resident of the sub-Canadian mixed forests, up to about 3,000 feet on the mountains. In the southern part of the state, the bird is now very rare, bnt along the ridge of land bordering the Connecticut from Monadnock to the White Mountains it is rather frequently seen, nor is it uswally very shy. I have seen three birds, a pair and a single, in one forenoon (July 9, I 894) at Walpole on the hills just east of the Connecticut River, and know of other birds observed there. Mr. G. H. Thayer has also found it nesting in the big timlser on Monadnock. About Lancaster, Whitefield and Jefferson on the west and north of the White Mountains, it is not unconmon, and Mr. F. A. Preble notes it occasionally in the heavy forests of Ossipee. 'To the north of the White Mountains it inhabits the coniferous forests and has been observed by

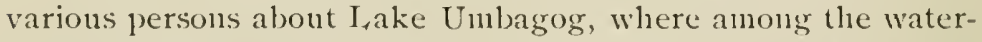
killed trees, it is said to be common. On the White Mountains it appears to be rare, though traces of its work are often met with, especially in the denser primeval forests. In one large swamp on Mt. Bartlett, I found a dead tree of a foot or more in diameter through whose trunk these birds had drilled a hole large enough to admit one's arm. 
135. Melanerpes erythrocephalus (I,inn.). RroIIEADE1) WOODE IECKIR.

A rare and irregular visitant in the sonthern and western lowlands of the state, appearing in stunner and fall. The following are the records which I have been able to gather: Alton, two lave been seen by Mr. Ned Dearborn ('98, p. 19); Charlestow'n, on May 25, r899, Mr. W. M. Buswell writes that he observed one: Dublin, Mr. G. H. Thayer writes that it has been seen once or twice; Hampton Falls, noted in June, r886, and September, r 897 , by Mr. W. E. Cram; Hanove, about i 88 I, a bird was seen alnost daily during the breeding season near the Dartmouth College grounds, as I am informed by Prof. Edwin B. Frost, who supposes that there was a pair breeding there; Hollis, adults noted by Dr. W. H. Iiox, Aug. I, I880, Sept. 8, i884, and in August, I886; Jefferson, recorded in Septeluber, 1900, by Mr. H. W. Wright (:02); Manchester, recorded on May 28, i899, by Mr. F. W. Batchelder (:oo, p. I27) who adds that it has been reported from Londonderry; Milford, Mr. J. P. Melzer writes that immature birds are sometimes brought in during the fall; Scabrook, Mr. A. A. Eaton -writes me of three immature birds seen previous to 1890 ; an adult male was shot in the spring about I896, and another aduit male in July of the same year, while an immature bird was sent in for mounting in the fall of 1899 ; Webster, about June, i 869, Mr. C. F. Goodhue ('77a, p. 96) records having taken two birds, "when they were around several days."

136. Colaptes auratus luteus Bangs. NORTHERN FLICKLER.

A not uncommon stmmer resident of the Transition areas, wintering in smail numbers on the coast, but only occasionally inland in the southern part of the state. In sunnmer a few are found well up into the valleys of the White Mountains and after the breeding season is over, are prone to wander up into the lower mountains to 3,000 feet or thereabouts. Thus in August and September, I have sometimes come upon a pair or a single bird on the ridges of $\mathrm{Mt}$. Bartlett and Kearsarge, and on at 
least two occasions I have noted a bird or two at Carter Notch $(3,360$ feet $)$, in the latter month. This deep notch or cleft in the mountain wall, with a valley opening ont to the north and another to the soutli, seems to serve as a passageway for a number of birds in migration, and I doubt not that these flickers had paused here to rest on their southward flight, for during the breeding season I have never observed them above 2,000 feet on these mountains. Mr. Ned Dearborn ('98, p. 19) has recorded that he has twice seen a flicker in Alton in Jannary. At Hampton Falls, on the coast, Mr. IV. E. Cran ('99) finds the bird a regular winter resident.

1:3. Introstomus vociferus (Wils.). WhIP-POORWILL.

A common summer resident of the Transition regions of the southern part of the state, but becoming rarer and local farther north. In some parts of central New Hannphire it is very common, as at Newfonnd Lake. On the outskirts of the White Mountains it is local in the sonthern valley:s, being found about ponds in dry sandy woods where there is an undergrowth of Bear Oak (Quercus ilicifolia), brake and blueberry bushes. In such a locality, a few are to be found every summer at North Conway, two miles south of Intervale, in the Saco valley. Frank Bolles ('95b) found them about his "Ironely Lake" at Chocorua, and at Lancaster, Mr. F. B. Spaulding has observed the bird also. Although their nightly serenades gradually cease as the summer wanes, the birds nevertheless remain upon their breeding grounds until well into September, and Frank Bolles notes them about his lake, so late as September 25 .

Inates: May 6 to september 25 .

1:3. Chordeiles virginianus (Gmel.). Nugrtindk.

A common spring and fall migrant, and a rather connmon summer resident of the Transition regions in the lower part of the state, following the valleys mp well into the lowlands of the White Mountains. In summer it is usually found in dry open woods, where there is more or less scrubby undergrowth. In 
the Saco valley, I have found a few each year during the breeding season at North Conway, anong the scrubly Bear Oaks that grow on a certain sandy tract it an altitude only a few feet above the valley (500 ft.). During the nonth of August flocks of these birds, sometimes numbering two or three hundred, I have frequently seen at Intervale, in late afternoon, moring leisurely down the Saco valley. The larger flocks often take a considerable time to pass a given point, as the individual birds fly quartering up and down, back and forth, so that the flock as a whole swings down the valley, completely past the observer, then back again, then down the valley once more, with each returning swing coning back a less distance until all are passed. Evidently the birds are feeding at such times. On August i9, IS97, I observed a large flock of over 200 birds thus passing down the Saco valley, when it finally broke into two divisions, one of which moved off northward up the valley, while the other continued on southward. At other times the flocks do not seem to be actively engaged in feeding, but each bird, usually separated by a considerable space from the next, flies swiftly on towards the south, as if with a distinct goal in view; and frequently such flocks are so scattered that barely a half.dozen birds are in sight at once, now a little group of two or three winging its way past, to be followed shortly by a single straggler or a pair. By the end of August, their migration is practically over in the IVhite Mountains, though an occasional belated migrant may be seen hurrying sonth during the first week or two of September.

Dates: (April I7, Hollis) May in to September 15 .

\section{Chaetura pelagica (Limn.). CHInNEY SWIFT.}

A common summer resident of the Transition area, especially about the larger centers in the southern and central parts of the state. In the White Mountains, a few are usually to be observed during the summer about almost every small cluster of llouses, or less commonly a pair or two will be found inhabiting a chimmey of some isolated farmhouse. At Intervale, there appear rarely to be more than a few pairs in any season, notwithstanding the abundance of chimneys. Dr. A. P. Cliadbourne 
('87, p. 104) records that on July 3, i 886 , he was given a specimen which had been caught alive in an unused chimney of the Halfway House on Mount Washington ( 3,840 feet) but that no others were seen during his short stay there, nor had the men at the house ever before observed the bird. Mr. Bradford Torrey ('8+, p. 57) also states that on June i 7 he found a company' of these birds "flying criss-cross over the summit" of Mt. Washington, but there is nothing to prove that they ever nest in any of the buildings there. Mr. Owen Durfee also tells me of a single bird seen flying about the summit on July 6, 1889. In their daily flights the birds often travel far from their nestingchimney, orer the woods, so that it is not uncommon, while on a trip through the nountains, to liear then chattering far overhead when the nearest building must have been two or three miles distant. During late August, I lave not infrequently seen them at Intervale, migrating southward, often in large flocks numbering upwards of one hundred birds, and at so great a height that they appeared but specks in the sky, though their distant cluattering could be faintly heard. On sucl occasions, a few Eave Swallows, distinguished by their flight, have sometimes been observed in company with the Swifts. The fall migration is practically over by the first week of September, though Mr. Bradford T'orrey ('96, p. 200) has once observed one flying swiftly southward near the Profile House so late as October I.

Dates: April 29 to September 7 (October I.)

\section{Trochilus colubris Lin11. RUBY-THROATED Hum-} MINGIIRD.

A not uncommon summer resident, and a common fall migrant. Though usually observed in the more open regions and about settlenents, it is also occasionally fonnd to nest in the woods at the lower altitudes, and I once saw a single bird at about 3,00o feet near Carter Notch, toward which it was flying. During the montl of August while the Jewelweed (Inpatiens) blooms in luxuriant beds in the lowlands, the humninglirds are constantly to be found about them. Often from four to six are in view at once, sone dipping daintily into the flowers, 
others with squeaks and twitters engaged in mock combat, while yet others rest momentarily on some dead twigs near by. After these flowers are through blossoming, by about September Io, most of the hummingbirds depart, though I have seen a few belated individuals at Intervale so late as the rgth of the month, hovering over the nasturtiums.

Dates : May I3 to September I9.

\section{Tyrannus tylammus (Linn.). KINGBIRD..}

A fairly common summer resident of the Transition valleys and up to about $\mathrm{r}, 500$ feet in the White Mountains. It is a characteristic orchard bird and is seldom found at any distance from the apple trees during the breeding season. After the young leave the nest the entire family is usually found to remain about their nesting ground in a small flock for the remainder of the season. By the last of August these family parties migrate southward, and joining one to another, soon form a flock of 20 to 30 birds. The attachment of these flycatchers to a chosen site is strong, and I know of a pair at Intervale which has nested for five consecutive summers in the sane apple tree which projects out over a small pond on the Saco meadows. I have seen on these meadows what I presume to be birds which had summered close by, so late as September $8, \mathrm{I} 898$, but most of them have left by the first of that montl.

Dates: May 3 to September 8.

142. Myiarchus crinitus (Linn.). CRESTED FlyCATChER.

An uncommon summer resident of the Transition and sub-Canadian woodlands, occurring in the White Mountains as high up at least as 1,500 feet. About Intervale, I have found it in fair numbers through June, but after that month the birds become retiring and their noisy calls infrequent, so that a careful search is necessary to discover them at all. They remain in these northern valleys until September.

Dates : May 13 to September. 


\section{Sayolnis phoebe (Lath.). PHabe.}

A rather common summer resident, especially in the southern and central portions of the state. It is generally found near bodies of water, or about barns and ontbuildings, following the settlements up to I, 500 feet or so. In numerous cases, what appears to have been the same pair of birds has returned year after year to build on the same spot. The males arrive ten days or a fortnight in advance of their mates, and occasionally one may see the joyful meeting of the two on some early April morning, the male launching himself into the air, alternately sailing and flying as he pours forth a succession of "chips" and "phecbes," and finally flutters down to a perch near his mate, who appears to take it all as a matter of course. At least two broods are usually reared, and the first brood may sometimes be seen lingering about the nesting site long after they are old enough to be independent of parental care.

Dates: March 26 to October Io.

144. Contopus borealis (Swains.). OlIVE-SIDED FilyCATCHER.

An uncommon summer resident, of general distribution in the breeding season througlout the sub-Canadian region, up to about 2,500 feet. It is most frequently found on dry hillsides where there is a scattering growth of spruce or pine, with dead trunks here and there; or it is found about open spaces in the denser woods. Mr. R. Hoffmann observed four males at Alstead in the summer of 1900 , and Mr. G. H. Thayer finds it about Mt. Monadnock in the heavier growth. Mr. William Brewster ('78, p. 177) has recorded a specimen taken at Rye Beach on July 24, 1872 , and Mr. W. E. Cram writes that it is found during the summer at Hampton Falls. About Lake Unbagog it is said to be common in summer.

Dates: May to September 3 .

\section{Contopus virens (Linn.). WOOD PEWrE.}

A rather common summer resident of the Transition and subCanadian regions, showing $n o$ decided preference for deciduous, evergreen, or mixed growth, and often, as I liave observed at Walpole and elsewhere, dwelling an1ong the large elins of the 
village street. Among the White Mountains, I have not observed them above 2,000 feet. Often I have noticed that after sunset or in the dusk of early morning, instead of the simple "pe-a-arce," the last two syllables are repeated as a sort of refrain, thus: "pe-a-zece, a-zece," given again and again in the twilight. I have also heard this variation on cloudy days, but only occasionally. In the White Monntains a few birds remain nutil well into September.

Dates: May 17 to September 17 .

\section{Empidonax thaventris Baird. YeLLOW-BELLIED} FLYCATCHER.

A common summer resident of the upper Canadian life area. On the White Mountains it is a characteristic' bird of the mossgrown, saturated forest of balsam and spruce, breeding in the from about 3,000 to 4,500 feet. It is also occasionally seen at lower altitudes in suitable outlying localities, and I have observed a pair on July 20 , I 899 , at about I, 500 feet on Mt. Bartlett among some hemlocks. The birds may have bred not far away, and acted as if young were near by. Both were heard to utter the "pu-ce" note. At Lancaster, Mr. F. B. Spaulding has found the nest of this bird, and records ('87) one with five fresh eggs found on June 14, r8s6, "near a low, swampy piece of moods." North of the White Mountains, it is found in the dense swampy woods, and was recorded about Lake Umbagog by Mr. C. J. Maynard (' 72 ). There are no recorded instances of its breeding sonth of the White Mountains, but I am assured by Mr. G. H. Thayer that he has found the bird in summer in a certain forest swamp on Mt. Monadnock at an elevation of about I, 400 feet. On June I 5, I902, on Imp Mt. of the Carter range, I heard one of these birds give a peculiar flight song, just after sunset. It flew slantingly upward for some twenty feet and repeated a number of times alten nately its ordinary "pu-ee" and "killick."

Dates : May 26 (Franconia) to August (September?).

14\%. Empidonax traillii alnorum Brewst. Alder Fliycatcher.

A rather common summer resident throughout the Transition 
valleys of the upper part of the state but less common in the southern quarters. It is confined almost exclusively to the alder swales along meadow brooks or about swamps and ponds. Mr. Ned Dearborn ('9S) has recorded it from Belknap and Merrimack counties; Mr. R. Hoffmann tells me that it is rare about Alstead; and Mr. G. H. Thayer finds it inhabiting the alder swamps at Dublin; I have found it rare at Bridgewater. In the White Mountain valleys it is locally common, and follows the alder growth up to about I, 500 feet. Farther north, it occurs at Umbagog, and along the alder-bordered streams in the open country. Mr. Bradford Torrey (:oo, p. 634) notes it at Franconia on the $23 \mathrm{~d}$ of May, and it was "abunclant" by the 26 th of that month. On the Saco meadows at Intervale, I found a freshly built nest on June 2 I, I 899. Four eggs were subsequently laid, one egg being deposited each day. In fourteen days the eggs had hatched. This nest was only about a foot from the ground and the date seems slightly late. The birds remain in the alder swamps until the last of August, and I have not certainly identified them after that month.

Dates: Mray 23 to Angust 31 .

\section{Empidonax minimus Baird. LEAST FLYCATCHER.}

A common summer resident, usually found during the breeding season in the vicinity of dwellings, and nesting in the orchard trees. It seems to follow civilization almost as closely as the Alder Flycatcher does the alder swamps, and extends its range up the valleys with the settlements, going as high at least as $I, 500$ feet. It is evident that the general introduction of apple trees throughout the eastern states must have had an effect on the habits of this species, as it is rarely found far from orchards, and shows everywhere a decided preference for the apple trees. After the young are off, the birds become more retiring, and often withdraw into the edge of nearby woods, deserting in part the vicinity of louses.

Dates: May 4 to September 2r.

14!). Otocoris alpestris (Lin11.). HORNED LARK.

A common spring and fall migrant and less common winter resident along the coast, but uncommon, if not rare, inland. 
Owing to the frequent confusion of this species with the Prairie Horned Lark, it is impossible now to say what proportion of the inland records for alpestris are really referable to that form. Probably, however, many or most of the single and paired birds taken inland during the spring are of the subspecies praticola, true alpestris being mure strictly confined to the coast. Mr. A. A. Eaton writes me that alpestris is common during winter on the beach at Seabrook, and I lave also seen it there in suall flocks flying northward on March 26, I900.

Dates: November to March 26.

150. Otocoris alpestris praticolar Hensh. PRAIRIE HORNED LARI:.

An uncommon spring and fall migrant and local summer resident. This bird was first recorded as summering in the state by Dr. Walter Faxon ('92) who says that on the 4th of June, I89I, his brother observed two birds haunting an old field in the town of Franconia and that their number was afterwards augmented by "what were doubtless the second-brood young." These birds were seen in the same spot as late as July 2 Ist. Mr. Bradford Torrey (: or) gives an account of the habits of these birds as observed by him at Franconia during May, I90I, when at one spot no less than five birds were found, and a half mile up the valley were two more pairs. Two years previous, no horned larks had been observed here by Mr. Torrey, who admits, however, that he may lave overlooked them. At Lancaster, Mr. F. B. Spaulding writes me that he is confident it breeds, as he has seen pairs there in midsummer, and "once in June saw a young bird just able to fly following its parent and begging for food." He also states that it arrives even in February in pairs and small flocks. Mr. H. W. Wright informs me that on Aug. 7, I899, he observed two perched on a fence bordering meadows by the Connecticut River in Lancaster. Furthermore, Miss Mary V. Blandy tells me that a small flock was observed at Jefferson (not far to the east of Lancaster) about a piece of ploughed land during the summer of I9oo, and that one of the birds was killed and identified as of this race. More recently, Mr. Ralph Hoffmann kindly permits me to record that 
on June 2?, 1903, at Errol, he flushed a female from her nest, containing two newly hatched young and one egg. He says that at least two pairs were breeding here. The only other summer record is that of a single bird seen by Mr. C. F. Goodhue at Boscawen on June 25, I9or. As far as at present known, therefore, the Prairie Horned Lark summers in New Hampshire in small numbers on the fallow and pasture lands to the west and north of the White Mountain region. A migrant bird was also recently sent me from Randolph, where it was taken on March 6, 1902, by Mr. V. D. Lowe.

Dates : (Last of February?) March 6 to August (September and October?).

\section{Cyanocitta cristata (Linn.). BLUE JAY.}

A permanent resident, of general distribution throughout the Transition and sub-Canadian areas of the state, apparently not breeding above 3,000 feet in the White Mountains. After the breeding season, small flocks, apparently composed of the individuals of a single family, are often noted wandering through the woods. In the White Mountains during August and September, these flocks reach the valley bottoms, and may then unite to form companies of from six to frequently 20 or 30 birds. They appear to be migrating in a leisurely way, and at Intervale I have frequently seen them moving down the Saco valley, in early forenoon or late afternoon. At such times, I have seen them, one by one, fly from one large tree to another farther down the river valley, where the first arrivals wait for the rest to come up, and then! move on again as before; or the entire flock nay keep well together and go trooping down across the meadows from tree to tree. It is possible that these 111igrations are not very extensive, but in the White Mountain valley's they are certainly well marked. In the northern woods, these Jays appear to be unusually quiet, and one may pass an entire day where they are not uncommon, without hearing their loud screans, though by in1itating their alarm cry, it is possible to get an immediate reply, and bring the inquisitive birds to the trees above one's head. The wandering flocks in summer occasionally reach considera- 
ble altitudes in their search for food; and Dr. A. P. Chadbourne has recorded ('87, p. I04) a small flock seen on Mt. Washington opposite the Halfway House $(3,840 \mathrm{ft}$.) on July 26, I 884. I have once seen a flock in the Carter Notch $(3,360 \mathrm{ft}$.) where, on Sept. I5, I900, at a sudden alarm call from one of the birds, an entire flock of eight flew up from among the scrubby growth. They seemed to have worked their way up one side of the divide, and continued through the walls of the notch down the other side, southward. Occasionally on late summer afternoons, I have seen small flocks of Blue Jays busily catching flying insects with all the ease and grace of a flycatcher. An old orchard tree is a favorite vantage point from which they fly out at the passing insects and with easy, graceful flight, snap up their prey, and then with set wings sail to a branch of another tree. I have watched small flocks engaged at this occupation for a half an hour or more at a time, the birds maintaining almost perfect silence throughout, save for an occasional low, rattling note.

152. Perisoreus camadensis (Limn.). Canada Jay.

A permanent resident of the upper Canadian zone of the White Mountains and the northern parts of the state. North of the White Mountains the bird is not uncommon in the dense coniferous forests, and Mr. C. J. Maynard ('72) mentions two specimens taken at Umbagog early in June. On the higher mountains of the Presidential and neighboring ranges the birds are rather common in the dense balsam and spruce growth from 3,000 to 4,000 feet. Dr. A. P. Chadbourne ('87) notes having observed small flocks of half a dozen on the Presidential range on three or four occasions, and Mr. Bradford Torrey, in his "Footpath Way," mentions having seen it once on Clinton and again on the side of MIt. Washington, where a small "family party" was observed. Mr. H. W. Wright has seen the bird several times on Mt. Adams, and once also on May 26, 1899, at Bowman's, a station on the north sicle of Adans, and at an elevation of only I, 500 feet. On the Carter-Moriah range I have found the bird usually in pairs during late summer, above 3,000 feet, and am told of nests having been found on 
these mountains. A few birds occur in summer on the outlying peaks of over 3,500 feet as on Tripyramid and on Black Mountain of the Sandwich range (F. H. Allen in literis) and also on Osceola. In the fall and winter there is a slight movement of the birds from the higher levels into the valleys, and occasional birds wander even into the southern part of the state. Thus Mr. C. J. Maynard ('72) found it " common at Eirrol, November 3 d, I879," and at Shelburne, Mr. R. H. Howe, Junior, ('99) reports that a bird had visited the lumber camps in December. At Passaconaway, Frank Bolles ('93a, p. 95) notes also that it is said to visit the camps there sometimes in winter. At Lancaster, in the upper Connecticut valley, Mr. F. B. Spaulding writes that he took a bird on November 30, 1899 , and finds it uncommon there. Farther south, there are several records for fall or winter, as at Bedford, a specimen from this locality is said to have been taken several years ago, and until recently was preserved in the collection of the Manchester Institute of Arts and Sciences ("Pinfeather Ornithologist," : 02, p. 173); Pittsficld, where Mr. Ned Dearborn ('98, p. 22) is assured of its occurrence by local authority; Penacook, where Mr. C. F. Goodhue writes me one was killed about I890; Raymond, one closely observed, as I am told by my friend Mr. F. H. Allen, on November 28, 1901, by a Mr. F. A. Lovejoy; Strafford, one recorded by Dr. Charles Palmer ('7I) as in his possession, shot in winter.

\section{Corvus corax principalis Ridgw. NORTHERN} RAVEN.

At present this species is an accidental visitant, for which the more recent records are: Canterbury, a specimen was trapped in early spring "a few years since," according to Mr. Ned Dearborn ('98, p. 22); Greenville, a specimen was killed at this town some years ago, as I am informed by Mr. J. P. Melzer, of Milford, who mounted the bird, but can give me no definite data; Sutton, Mr. C. F. Goodhue records ('85) one taken and another seen here on December 20, 1878; Warner, a bird secured about February 18, 1879, according to M. C. Harriman ('79). Many writers have presumed that the raven breeds in the 
White Mountains, but no evidence has ever been cited as a basis for such a belief. I have had occasional reports of the bird from this region, but none that I considered trustworthy.

\section{Corvus americanus Aud. AMerican Crow.}

A common summer resident throughout the Transition and sub-Canadian regions; it is abundant as a spring and fall migrant, but as a winter resident it is rare in all but the sonther: portions of the state. Among the White Mountains, crows nest up to 3,000 feet or so, but are not to be found in the deeper woods at a distance from open farm lands. Dr. A. P. Chadbourne records ('87, p. I04) two birds seen in July on the bare rocks at 5,350 feet on MIt. Washington, whither they had evidently flown from below. Late in the summer, they gather in small flocks, to feed by day on the meadows and lowlands; at sunset they may often be seen flying toward the mountains at a considerable height, to roost. These smaller flocks unite, by September, to form larger, which migrate southward in late September or early October. A few birds winter with some regularity as far north as the White Mountain valleys. At Intervale, I saw a bird on Dec. 26 , I90o, and farther up the valley, at Jackson, they occasionally winter. They have been recorded by J. W. Nash ('88) as having wintered at North Conway. To the north of the White Mountains, they are rarer in winter; Mr. R. Li. Howe, Junior, ('99) has recorded seeing the bird at Shelburne the last of December, I897. In the Connecticut valley, "E. C." ('86) states that crows passed the winter of 1886 at Hanover, "a rare incident." In the southern parts of the state, they are sometimes common in winter, and in a journey by train up the Merrimack valley on Feb. IO, 1900, occasional birds were seen along the river, and at Manchester a flock of from 30 to 40 was observed from the car window feeding on a large pile of refuse. About Webster, that same winter, Mr. C. F. Goodhue had observed crows to be wintering in larger numbers than usual, for the season was comparatively mild. On March 26, I900, on the coast at Seabrnok, during the entire forenoon, I observed Crows flying northward in snall groups of from 3 to 30 , at varying intervals apart. At least three or four hun- 
dred birds were counted in about two and one-half hours. They flew low and with the light southeast wind, and appeared to be following the coast line in their flight.

\section{Dolichonyx oryzivorus (Linn.). Bobolink.}

A common summer resident and abundant fall migrant throughout the broad meadows of the Transition valleys. In suitable localities it is common even up to the foot of the White Mountains and in the Connecticut valley at least as far up as Lancaster. North of these mountains, however, it is much less common. Mr. H. W. Wright writes me that four or five pairs breed every season at Jefferson Highlands, and Mr. F. H. Allen has also observed it in this region. At Intervale where the bird is plentiful, the young are hatched and have left the nest by the last of June, and the adult birds of one meadow or of one circumscribed area sometimes flock as early as July $4^{\text {th }}$, keeping rather closely together, while yet feeding their well grown young in the grass. These latter remain concealed until closey approached before they take wing and fly straight away to drop into the grass farther off. As the young grow stronger on the wing, they join the flock of old birds, and by the last of July, flock joins flock, until large companies are formed which wander about to some extent before moving southward. Often I have noticed, during August, flocks of Bobolinks flying north ward up the Saco valley towards evening, the movenent appearing to be a general one, though of its purpose I am ignorant. Others again are to be noted passing southward down the valley, sometimes at a considerable height in the air.

Dates: May 5 to September 9.

\section{Molothus ater (Bodd.). Cowbird.}

An uncommon summer resident of the Transition valleys in the southern and western part of the state; rarely wintering. The distribution of this bird in New Hampshire is of interest ; it is not uncommon in the extreme southeastern portions of the state, and numbers work up the Merrimack valley, where in certain localities it is said to be common, as at Hollis (Fox, '76), Manchester (F. W. Batchelder, : oo), Webster (Goodhue, 
'77a) and Tilton (Dearboru, '98). Mr. Dearborn (1. c.) has also observed it rarely at Alton near the sontheastern end of Lake Winnepesauke. North of this lake, save in the Connecticut valley basin, the bird is practically wanting, and appears not to occur at all in the White Mountain valleys in summer, though Mr. H. C. Sargent tells me that in the fall of 1902 he saw it at Chocorua. In the western part of the state, it is of regular occurrence in the Connecticut valley region. At Alstead, Mr. R. Hoffmann has found it rare in summer; Mr. G. $H$. Thayer writes me that it is common at Keene, and on one or two occasions stragglers have appeared at Dublin; at Charlestown it is common, according to Mr. W. M. Buswell, and still farther up, at Hanover, Mr. E. B. Frost has found it in numbers. The most northern breeding locality in the Connecticut valley known to me is Lancaster, where Mr. F. B. Spaulding has not infrequently seen the bird and found its eggs. These Connecticut valley birds seem to keep close to the river, and rarely get into the mountain valleys on either side; indeed, the only record $I$ have for the Franconia region is of a bird seen October 2, I887, at Franconia by Dr. Walter Faxon. Mr. F. B. Spaulding has twice noted a single cowbird wintering at Lancaster; one was shot there on Jan. I8, I895, which had been noticed throughout the winter feeding on the streets with the English sparrows (Spaulding, '95), and a second was seen into December, I899, staying about with the sparrows.

Dates: March 25 to October 2 ; (winter).

\section{5\%. Agelaius phoeniceus (Lini1.). RED-WINGED BLACKBIRD.}

A rather common, but local summer resident, breeding in marshes and open swamp land throughout the Transition areas; accidental in winter. It is found rather commonly about the rivers and lakes of the southern parts of the state, and a few colonies are found even among the White Mountain valleys and at Unbagog. The young are on the wing by July, and at Intervale I have never seen the birds later than August 2 ist, as they leave their breeding grounds during the first part of that month. Mr. C. F. Goodhue ('85) records that a fine specimen 
was taken at Warren by Mr. M. C. Harriman, on January 7 , I 878 .

Dates: March 3 to September; (winter).

\subsection{Sturnella magna (Lin.). MEAdowLARK.}

A summer resident of the Transition valleys, uncommon in the southern parts of the state, and rare so far north as the White Mountains; rarely or perhaps accidentally wintering. On the coast, at Hampton Falls, Mr. W. E. Cram writes me that it has been observed at all seasons. It occurs in fair numbers in the Merrimack River basin, as at Hollis, and Manchester, and farther up at Webster, Tilton and Gilmanton (Dearborn, '98). In the Connecticut valley basin, the bird is not uncommon as far up at least as Charlestown, as observed by Mr. W. M. Buswell and myself among others. Mr. E. B. Frost writes we that two or three pairs breed yearly about Hanover. Mr. Bradford Torrey (:oo, p. 638) records a single bird singing at Franconia, May 22, I899, which may have straggled up the Connecticut valley; the bird was unknown to the Franconia people. Still farther up, Mr. F. B. Spaulding of Lancaster found a single pair nesting on his father's meadows at that town in I90r, the first he had ever noted there. At Intervale, in the early '9o's, a pair of these birds bred for a few seasons on the Saco meadows, but were finally shot, and none have since appeared until 1902, when a pair was noted during the summer months, with four of the full-grown young, and again in the early summer of I903. Mr. C. F. Goodhue ('85) records that a single bird remained at Webster through the winter of $1874-75$.

Dates: March 26 to October 12 ; (winter).

\section{Icterus galbula (Linn.). BALTIMORE ORIOLE.}

A summer resident of the Transition portions of the state, rather common in the valleys and lowland towns of the southern part, but becoming rare in the White Mountain region. A bout the larger southern towns, it delights to nest in the elms of the village street. In the valleys on both sides of the White Mountains one or two pairs are found about nearly every hamlet, though apparently fewer occur on the northern side of the range. 
At Intervale, a pair is usually found nesting eacl season, and the birds, after the breeding period is over, remain about the village, often roaming over the lowlands a mile or more from the nesting site. I have seen what were apparently these summering birds, up to the first of September, at Intervale.

Dates: May 6 to September 1 .

160. Ścolecophigus carolints (Mull.). RUSTY BLACKBIRD.

A common spring and fall migrant and in the northern part of the state, a rare summer resident. Mr. C. J. Maynard ('72) records seeing a few at Lake Umbagog in June, and Samuels (' 67, p. 55 r) states that he found several in June, r 864 , in the valley of the Megalloway River in Maine. Doubtless a few breed regularly in the swamps of this wooded region. In the White Mountain valleys they appear in small flocks about the first week in September, and Mr. Bradford Torrey has observed them in Franconia up to October 2.

Dates: March 8 to April ig; summer (northern N. H.); September 9 to October 2.

\section{Ruiscalus quiscula deneus (Ridgw.) BRONZED} GRACKLE.

An uncommon summer resident of local distribution, mainly within the Transition zone. Colonies are not infrequently found in the southern part of the state, along the coast and in the Merrimack and Connecticut valleys. At Manchester, according to Mr. F. W. Batchelder (:oo, p. I9) it is a "rare transient visitant." Mr. C. F. Goodhue has found a small breeding colony near Webster, and Mr. Ned Dearborn ('98) considers it a conmon summer resident in Belknap and Merrinack counties. Dr. Walter Faxou has also observed a flock at Plymoutl, May 26, I895. Mr. G. H. Thayer assures me of its presence at Kecne and Marlboro. In the Connecticut valley at Charlestown, Mr. W. M. Buswell finds it unconmon, and I have seen a few individuals at Walpole in early July, I894. In the upper Connecticut valley, Mr. F. B. Spaulding writes me that at Lancaster a dozen or more pairs nest in some evergreens at the head of the main street, and that there were formerly nore, but their 
numbers have decreased since the removal of some of the trees. At Lake Umbagog, Mr. IVilliam Brewster (' $76 \mathrm{~b}$ ) records that numbers breed in the old woodpeckers' holes or natural cavities of the standing, water-killed trees by the mouth of the Androscoggin. Throughout the IVhite Mountain valleys, and most of central New Hampshire north of Lake Winnepesaukee, the bird seems to be entirely absent. Frank Bolles ('93b, p. I26) states, however, that at Chocorta, according to the old residents, this species and the meadowlark were formerly common, when flax was cultivated there, and grain fields were broader.

Dates : March I 2 to November.

16\%. Coccothranstes vespertinus (Coop.). EvEnING Grosbeak.

An accidental visitant from the northwest, known to have occurred only during the famous i 890 flight, when so many were recorded from New England. During this incursion, the last recorded specimen was taken in New Hampshire. Following are the separate 1ecords for the state: Francestown, a fine male was captured by Mr. T. Edward Bishop on March 27. I890. A female accompanied this bird, but was not captured (Colburn, '9o); Henniker, a single bird. the last recorded of this remarkable flight, in New England, was shot by Mr. Aubrey B. Call ('9o) on May I, I89o; Milford, several were secured by Mr. J. P. Melzer ('9o), who records that on January 6, I 890 , five were obtained, and four others on January 9 th, from a flock of $\delta$ or Io birds of both sexes. These were among the first specimens to be obtained in New England. Seabrook, a male was shot about Jan. 9, I890, by a Mr. Boyd, according to Mr. William Brewster ('96). A female accompanied this bird. Mr. A. A. Eaton of Seabrook writes me of what must have been this same specimen, that it was one of a flock of six which appeared early in Jannary, and that it was presented to hin on the gth, after having been several days dead. Irater it was given to Mr. William Brewster. The fact that there are no records for the northern part of the state is probably duc to lack of observation, for Mr. O. W. 
Knight ('97) records one captured so near the White Mountains as Fryeburg, over the border in Maine.

Mr. E. H. Forbush ('9o, p. 210) suggests as a possible cause of this remarkable flight, the prevalence of strong west winds, following some of the cyclonic storms of the early winter.

Dates: January 6 to May 1, I8go.

1(i3. Pinicola enucleator leucura (Mull.). CanadAn Pine Grosbeak.

A permanent resident, breeding in small numbers throughout the saturated forests of the upper Canadian area of northern New Hampshire and on the White Mountains; as a winter resident it is of regular occurrence over the whole state, though in varying abundance. In the wet balsan forests above 3,000 feet on the White Mountains, this bird is an uncommon summer resident. The first published record of its presence here in summer seems to be that of J. E. Cabot ('57) who mentions having seen them "at the White Mountains in Angust," nearly a half century ago. Dr. A. P. Chadbourne ('87) next records two specimens seen, both of them in the low spruce and fir timber opposite the Halfway House on Mt. Waslington, (altitude, 3,80o feet). One was a fine adult male in full song, seen July I2, I 884 ; the other an inmature bird, seen Jnly I3, i 886 . Mr. Bradford Torrey ('9o) notes two bright males and a third bird in dull plumage at Eagle Lakes (4,000 ft.) among the Franconias on June I9, I889, and again at the same place on June 28 th, three were seen and one heard singing. I had never observed the bird on numerous camping trips on the higher mountains until June, I902, when on the I4th of that month a finely plumaged male was seen at 3,500 feet in Carter's Notch, singing gaily. He soon flew on higher up the mountain side. The following day a second male was observed about seven miles farther along on the same range. He sang persistently, notwithstanding the drizzling rain, and appeared to be established annong the firs at an elevation of about 4,500 feet near the top. of North Carter. I have no doubt that a few birds regularly breed at these upper levels. In the northern part of the state a few breed at the 
Connecticut Lakes. Mr. H. A. Purdy states that in 1876 he observed young birds the last of July, being fed by their parents at these lakes. A writer in Forest and Stream, signing himself "N. U." ('s $\left.S_{3}\right)$ records finding them in pairs at Second Connecticut Lake on May 24 th, I $88_{3}$. Mr. C. J. Maynard (' 72$)$ did not record this species in summer at Umbagog, though from the nature of the country, it may well occur during that season. About the first, of Norember, these birds begin to appear in small numbers in the lowlands and throughout the more southern parts of the state, and Mr. C. F. Goodhue has observed them at Webster so early as October 25. After a late winter, they linger as long as the snow remains on the ground, and I have seen them still in flocks at Chocorua up to April 20, while the melting drifts yet lay deep in the woods. Perhaps these lingering flocks are mainly composed of birds which summer on the higher peaks near by, or at no great distance northward. The great abundance of Pine Grosbeaks during some winters, and their scarcity in others is an interesting fact, the determining causes of which remain to be worked out.

164. Carpodacts purpureus (Gmel.). Purpin Finch.

A rather common summer resident throughout the sub-Canadian and Transition areas of the state. Among the White Mountains, it is fairly common in the valleys, arriving about the middle of April, and scattering birds may be found in the woods up to 3,000 feet. It is said to occur commonly at Lake Umbagog. Doubtless a few winter irregularly in the southern part of the state; Frank Bolles ('93b) records seeing a number at Chocorua on Decenuber 22d; Mr. C. F. Goodhue ('85) includes it anong the winter birds of Webster; and a Mr. J. H. Johnson ('92) records it fron "central New Hampshire" as having been "very scarce during the winter of I $891-92$.

165. Loxia curvirostra minor (Brehm). AMrRICAN C'ROSSHILL.

A pernanent resident, of notorious irregularity in its numbers and movements. At times the bird is common all summer in the sub-Canadian woods of the state below 3.000 feet and in 
the White Monntain ralley's, and later in the season invades the lower parts of the state; again one sees but few even in the most farorable localities. The Red Crossbill is mainly a bird of the sub-Canadian areas, whose appearance at any season of the year may be looked for, while the White-winged species seems more definitely restricted, during summer at least, to the upper Canadian forests, and rarely appears in the lowlands till fall or winter. Mr. C. I*. Goodliue ('77a, p. 49) has recorded that a few have been known to breed near Webster. They doubtless breed regularly also among the White Mouncains, whence I have had occasional reports of nests. The great crossbill flight of rS99-1900, when this and the following species were so abundant, is mentioned under Migration.

166. Loxia lencoptera Gmel. WhitF-IVINGED C'Ross$B I L, L$.

A permanent resident of the upper Canadian spruce and fir forests in the northern part of the state and above 3,000 feet on the White Mountains; elsewhere it is of uncertain and irregular occurrence, sometimes appearing in numbers during the cold months. Among the White Mountains small flocks or single birds are almost always to be found in summer in the damp forests at the higher levels. Mr. Bradford 'Torrey has recorded them in June at Eagle Lake, among the "Franconias, and Mr. C. J. Maynard ('72) quotes Mr. Willian Brewster as having found them at Franconia in summer, and adds that they were common in June, 1870, at Lake Umbagog. On numerous camping trips on the higher White Mountains, the Presidential and Carter ranges, I have usually found a few in summer; and among the wilder forests of the Carters, not infrequently I have observed flocks of a dozen or twenty birds above 3,000 feet, in Jume, July, and September. In the summer and fall of I899, and during the following winter there was an unusual incursion of these birds over the southern part of the state'and beyond, which has been considered at length in the chapter on Migration. I am informed by guides that Crossbills of this or the pre- 
ceding species have been found breeding on the White Mountains in late winter, and they donbtless do so likewise at Umbagog and northward. The song, which I have sometimes heard, in July, is a series of trills, alternately high and low.

\section{6\%. Acanthis linaria (Linn.). REDPOL.}

A winter visitant, of irregular abundance, from the north. Probably but few winters pass when none of these birds visit the state, and though rare in some seasons, in others they come in great swarms, frequenting largely the birches on whose seeds they feed. Specimens from these flocks show a considerable range of variation in size and markings, but all which I have seen from the state were referable to typical linaria rather than to any of the several other species and subspecies. Doubtless A. l. rostrata occurs at times along the coast, and indeed it lias been reported from Manchester (Proc. Manchester inst. arts and sci., Vol. II, 1901, p. 80,8 I) but the record is not properly substantiated.

Dates: November $I$ to April.

168. Astragalinus tristis (rinn.). AMFrICAN GOLDFINCH.

A common permanent resident over most of the state save the deeply wooded portions above 3,ooo feet, and usually occurring in flocks except for the short period in late summer when the birds pair off to breed. Tllough commonest in the open valley lands, they are also to be found on the forested mountain slopes, and not infrequently they may be seen crossing the higher ranges, or even passing by the summit of Mt. Washington itself, though rarely, if ever, stopping at these heiglits. In winter they may be found in small flocks at least as far nortl as the White Monntain valleys, and I have seen small flocks at Jackson and near Glen Ellis Falls in Pinkliam Notch during the last days of December after extremely cold weather and much suow. Mr. C. J. Maynard ('72) states, however, that he did not find them wintering about Irake Unbagog.

169. Spinus pinus (Wils.). Pine Siskin.

A conn1non permanent resident of the Canadian region, and 
occurring also throughout the lower parts of the state as a fall and winter visitant. Over the lower part of the state they are sometimes rare for an entire season, and again appear in great numbers. After a winter in which they have been plenty, stray birds seem to drop out as the main hight recedes northward, and these may sometimes breed at the lower altitudes. Annong the White Monntains, a few are almost alway's to be found in the lowland valleys, but they seem usually to be crossing from one mountain to another. In the upper Canadian zone above 3,000 feet, on the mountains, they are common in the spruce and balsam forests and young fully grown niay be found so early as June 23d, flying about with their parents. At the same time, also, large flocks may be encountered. 'Thus on June i5, 1902, I cane upon a flock of over 40 individuals in the woods on Carter Done at 4,500 feet, and again during the latter part of June, I9oo, numerous flocks up to as many as 50 birds in a si11gle one, were observed in the valley about Intervale, as well as pairs here and there. These flocks were wandering about the lowlands, and may later have broken up in part to breed. It is evident, however, that in this respect, the birds are somewhat irregular. These are restless, active little creatures, and when observed among the mountains are usually in flight overhead. I have rarely failed, on trips over the main ranges of the White Mountains, to hear a few single ones or an occasional pair, and to observe them passing swiftly by from one range of mountains to another, or dropping down into the forests below. Prof. Edwin B. Frost writes me that at Hanover, he and his brother found three or four nests in two different years, with eggs about the middle of April. Mr. C. F. Goodhue also observed a pair building a nest in a large pine at Webster during the last of April, 1900, but they later deserted it.

1\%0. Passerina nivalis (Linn.). SNowriake.

A rather common spring and fall migrant and winter visitant throughout the open lands of the state, but of more regular occurrence on the coast than inland. Mr. C. J. Maynard ('72) records that they appeared in Coos County in the latter part of October, 1869 , and occasional individuals are known to appear 
in the southeastern parts of the state by the very last of the same month. A late spring specimen is preserved in the collection at the Acworth Public Library, taken at Acwortle on April 6, r883. Mr. C. F. Goodhue also has in his collection a male in summer plunage, taken 11ear lis house at WVebster in June, a few years since. One of the bird's wings had been injured, though Mr. Goodhue says it could fly quite well. Doubtless, howerer, it was unable to continue its migration. It is now generally conceded that the nest, described to Audubon (' 60 , III, p. 56) by Wright Boott, as seen " on a declivity of the IVhite Mountains of "New Hampshire," and stated by Audubon to have been of this species, must have been that of the Slate-colored Junco. also called Snowbird.

Dates: October 25 to April 6.

171. Ponecates gramineus (Gmel.). VESPER SPARROW.

A fairly common summer resident of the grassy bottom lands and dry hillside pastures throughout the Transition valleys of the state. Among the White Mountains, they follow the ralley clearings up to about $\mathrm{i}, 500$ feet. During September they gatlıer in small flocks in the fields preparatory to nigrating, and at such times are often accompanied by a few Savanna Sparrows. At Intervale, I have occasionally leard individuals singing with uncertain voice, so late as September 15. Here too, as elsewhere, a decided falling off in point of numbers was observed in case of this species diring I S94 as an effect of a late freeze which proved so disastrons to many birds. At Chocorua in 1900 I found a pair to have arrived by April I5, while the melting snow still lay in places nearly a foot deep on the ground. In the sontherin part of the state the birds appear a few days earlier.

Dates: April 7 to October.

Note: Ammodramms minceps (Maym.). Ipswich SPARrow.

Although doubtless occurring among the sand dunes on the coast, this bird has yet no definite claim to a place on the New Hampshire list. The record by Mr. N. C. Brown ('77) of one seen by him at Jake Unbagog has since been expunged (Brown, '96). 
1\%. Ammodianus sandwichensis savanna (Wils.) Savanna Sparkow.

A common summer resiclent, es pecially of the broad Transition valleys, where it frequents the meadows with the Bobolinks. Occasional pairs follow the cleared land well up onto the hillsides, where, as at Jackson, among the White Mountains, I have observed them up to I,600 feet or so. Mr. G. H. Thayer also reports that a few breed at Diblin, on a high, grassy, pasture hill, at r,600 feet. On July 7 th, is98, and on the following day, while on a trip over the Presidential range, I observed a single Savanna Sparrow singing, as if quite at home, from a rock on the northeast side of the summit of Mt. Washington, but a few yards from the buildings, and it is not impossible that a pair was breeding there among the sedges.

Dates: April 20 to October.

\section{1\%3. Ammodranus savammarum}

passerinus (Wils.). Grasshopper SpARrow.

A rare summer resident in certain localities among the Transition valleys of southern New Hampshire. A few follow the Connecticut valley meadows up so far at least as Walpole, where Mr. R. Hoffmann observed a single bird in I899, and another in I900. Others push up the Merrimack valley, apparently with some regularity. Dr. W. H. Fox writes me of one noted at Hollis on May I3, I876. Mr. C. F. Goodhue ('77a, 49) has recorded its occurrence in summer at Webster; Mr. Ned Dearborn ('98, p. 25) also states that he has usually found one or two each season in the neighborhood of Tilton, still farther up the valley. Beyond Lake Winnepesaukee the bird seems not to occur.

Dates: May iz to Summer.

174. Ammodramus henslowii (Aud.). HensLow's SPARROW.

A local summer resident, breeding in sull numbers in cool, open swamps of the Transition area grown up to sedges, grasses. small bushes and the rank hellebore. Apparently this bird is a species characteristic of these peculiar " islands" of the 
Transition zone. Mr. C. F. Goodhlle was the first to make known the fact that Henslow's Sparrow is a regular summer resident of New Hanpshire (see R. Deane, ' 7 Sa). He found it in small numbers in certain neadows abont Webster, and the adjacent towns of Boscawen and Salisbury, over 25 years ago, and observed a nest of four young birds on Angust 16, 1877, at the last nanied place. This record has remained the only published instance of the bird's presence in the state, thongh H. D. Minot, in his " Land and Game Birds of New England,' ('77) states that he had "suspicions **** that they occur in at least one spot among the White Mountains." More recently, however, Mr. G. H. Thayer writes me that "on the Ist of August, several years ago," his father "shot a Henslow's Sparrow, and saw two others high up in the IValpole hills some ten miles " northwest of Keene, in a small isolated wet place, grown with rank grass and small bushes, in the midst of a wide expanse of open hill pasture, at about I, ooo feet altitude; he has also noted the bird at Dublin in June, r902, and at Hancock and Bennington. Mr. R. Hoffmann has also observed the bird on one or two occasions near the same locality, at Alstead. Elsewhere in the state, I know of its presence only at Wonalancet, on the intervale at the foot of Mt. Passaconaway. Here, on July I 4 and I5, I899, I observed a pair eridently settled, in a small cold marsh, partly carpeted with sphagnum, and grown up with sedges and white hellebore. On the tops of the hellebores the male would sit and sing incessantly, but only once did I observe what must have been his mate. I have been unable to visit this spot since to discorer if 1 is regularly inhabited by the birds.

Dates: April i 7 to August.

1\%5. Ammodramus caudacutus (Gmel.). SHARPTAILED SPARROW.

A summer resident of the salt marslies on the limited coastal strip of the southeastern part of the state. Dr. Jonathan Dwight, Jr.. ('87) states that true caudacutus breeds as far north as Portsmouth. Mr. Wrilliam Brewster ('78) also mentions a specimen in his collection taken at Rye Bcach, on August 20, 
I869. Doubtless the subspecies subuirgatus occurs in migrations, but records are not available.

Note: Ammodlamus maritimus (Wils.). SEASIDE SPARRow.

The statement of Dr. Elliot Coues in his "Birds of New England" (Iroc. Essex Inst., Vol. V, p. 282) that this species occurred at Rye Beach, was an error, the sharp-tailed sparrow having been the bird intended (Brewster, '77b).

\section{$1 \% 6$. Zonotrichia lencophrys (Forst.). White-}

CROWNED SPAKROW.

A spring and fall migrant, uncommon in the lower parts of the state, but seemingly more plentiful in the higher country. More birds are seen also in fall than in spring. Mr. Bradford Torrey and Mr. H. WV. Wright have found the bird regularly annong the White Mountains from September 25 into October, and Mr. G. H. Thayer reports it as sometimes common at Monadnock in Migrations. I have observed it on one occasion on the Saco meadow's at Intervale so early as September 2 I, I900. During the spring of igoo this species was seen at many locali. ties in unusual numbers, and Mrs. E. E. Webster informs me that at Franklin Falls it seemed more plentiful than the Whitethroated species during May of that year.

Dates : May 6 to 25 ; September $2 \mathrm{I}$ to October $\mathrm{Ir}$.

1\%. Zonotrichia albicollis (Gmel.). WHITE-THROATED SPARROW.

A common spring and fall migrant, and as a summer resident, common throughout the Canadian portions of the state and even up into the sub-alpine zone on the IThite Mountains. South of Lake Winnepesaukee, it breeds on Mt. Monadnock and the surrounding hills, on South Kearsarge, and elsewhere locally along the higher land in the western part of the state. Among the foot hills of the White Monntains, scattering pairs breed even at low elevations in the valleys in bushy open spots, but it is not very common until the deeper sub-Canadian woods are reached. On the mountains it is common up to the limit of scrub growth at 4,800 to 5,000 feet, and a few push still ligher up to avail themselves of outlying clumps of stunted growth. I 
have observed a few in simmer about the Lakes of the Clouds on Mt. Washington at some 5,000 feet, and Dr. A. P. Chadbourne ('S7) notes them as high as 5.300 feet.

Dates: April 23 to May If; Summer; September and October.

175. Spizella monticola (Gmel.). TREE SPARROW.

A common spring and fall migrant and less common winter resident. In fall the main fight passes through during late October and November, and a few are left to winter at least as far north as at the White Monntain valleys, as at Ossipee, where Mr. E. A. Preble has noted them in winter. Frank Bolles (93b) records two seen on December 2 ist, at Chocorua, but it must be rarely that the birds winter there. Mr. F. B. Spaulding also writes of seeing two on Dec. 9, I899, at Lancaster, the latest he had erer noticed them there in winter. During March and April the northward flight takes place, a few birds lingering nearly to the last of the latter month.

Dates: October $S$ to April 24.

\section{Spizella socialis ( Wils.). ChIPPING SPARROW.}

A common summer resident of the Transition area, found mainly about orchards and door-yards, and one of the most. familiar and confiding of our native birds. Like the Least Flycatcher, it follows closely the path of civilization and has doubtless greatly extended its range within historic times as the forests have disappeared before the advance of the white man. Already by August fanily flocks of old and young are seen, and by the latter part of that month these join one to another, until large companies are formed. At such times the birds fairly swarm over weedy fields or stubble land, and often are accompanied by Bluebirds and Myrtle Warblers. These flocks move leisurely southward during September, thougl a few individuals remain anong the White Monntains until well into October. Prof. C. M. Weed ('98) has given a good acconnt of the feeding habits of this bird, as observed by him at Durham.

Dates: April 16 to October 11.

180. Spizella pusilla ( Wils.) Fmirl SArrow.

A summer resident, common in the southern part of the state 
on bushy litlside pastures, but becoming local and uncommon anong the White Monntains. About the Winnepesaukee region the bird is very conmon in suitable places, and follows the valleys well up anong the 1110 nntains on both sides of the great range. On the sonth side of the range, I have found small colonies in the Saco valley at North Conway and Intervale, and a few pairs still farther up at Jackson, on the western slope of Spruce Mountain, facing the Glen road, and at an elevation of about $\mathrm{I}, 500$ feet. On the north side of the range, Mr. F. H. Allen has found them not uncommon at Jefferson and Randolph, these birds very likely reaching this district by way of the Connecticut valley. It is noticeable that a large part of the nests found in sonthern New Hampshire are built in low bushes. After the young are on the wing, the birds continue on their breeding grounds in small family flocks, into September, and Dr. Walter Faxon has observed them at Franconia so late as October 7 .

Mates: April ig to October 7 .

181. Junco hyemalis (Limn.). State-COLORED Junco.

An abundant spring and fall migrant, and throughout the Canadian area, a common summer resident of coniferous woods or open, dry pastures grown up to small pines or spruces; also a winter resident in the sonthern part of the state. South of Lake Winnepesaukee the bird is local in smmmer, breeding in suitable localities, as at Northfield on Bean Hill, South Kearsarge (Dearborn, ' 98 ), on Mt. Monadnock above 1,500 feet in the spruce growth ('Thayer, in lit.), and along the ridge of 'land in the western part of the state northward to the White Mountains. At Intervale, a few pairs breed even in the valley bottom of the Saco at 520 feet, and thence up to the limit of scrub growth on the ligher mountains, at 4,800 to 5,00o feet. A bove this level a few scattering pairs are to be found here and there where an outlying clump of dwarfed firs provides shelter, and a few birds are nswally to be found feeding about the buildings on the extreme summit of Mt. Washington (6,29r feet). I have no doubt these birds nest on the summit, and they must surely find an abnudance of insect food. In the sonthern part of the state, the bird is known to winter in small numbers; Mr. IV. E. 
Cram writes me that it occurs through the winter months at Hampton Falls, and Mr. C. F. Goodhue ('85) records it as a winter bird at Webster. I do not know of its wintering farther north, though Frank Bolles ('93b) records a flock scen on Bear Mountain on Dec. 2I, I89I. The birds arrive on their breeding grounds annong the White Mountains before the snow is off, and I have observed the males in mid-April singing among the stunted growth on the summit of Mit. Chocorna as though completely at home and settled for the season. Young, just hatched, were observed at Jackson on June I6, 1902.

\section{8:. Melospiza melodia (Wils.). Song Sparkow.}

A common summer resident throughout the Transition regions, breeding as high up at least as 2,00o feet among the White Monntains, in more or less cleared areas. Dr. A. P. Chadbourne ('87) records having seen a single bird "on the bare rocks at an altitude of 5,340 feet on MIt. Washington" on July 6, I 886 , and he suggests that it may have nested somewhere near. Mr. C. J. Maynard ('72) records its breeding at Lake Unbagog the last of May, and adds that he has seen the bird in Coos County "the first week in November, when the snow was on the ground." During September large flocks often gather about the weed patches in the lowlands, or swarm in the swampy thickets preparatory to migrating southward. Doubtless a few winter in the southeastern portions of the state, but actual records are tu1available.

Dates: March 9 to December.

183. Melospiza lincolnii (Aud.). Lincoln's Sparrow.

A migrant, apparently rare in spring, but rather common in fall. Owing to its inconspicuous dress and retiring habits it is very frequently overlooked. On the Saco nneadows at Intervale, I have observed it in the fall migration as early as September 7 , on which date, in 1899 , two birds were seen by Mr. R. H. Howe, Junior, and myself, one bird being taken. After this date, from one to as many as five were seen alnost daily throughout the month. Often one or two individuals are found in company with the large flocks of Song Sparrows which at 
this season frequent the weed-grown potato patclies, or an occasional bird is found among the tall grass and bushy tangle on the edge of a swanp or wood. One soon learns to recognize the neat, graceful form, the uneasy movement and inquisitive way of the bird, as it hops restlessly about, now appearing on the edge of a thicket or tangle of grass to peer curiously at the observer, or again vanishing utterly in situations where the cover seens too slight to conceal it at all. I have sometimes heard from this bird in the fall, a sluarp and distinctive " chip " much like a note of the Vesper Sparrow; also on a few occasions a short, low " tzz," similar to a note of the Song Sparrow and given as the bird skulks among the shrubbery. Mr. Torrey has on several occasions noted this bird among the Franconia valleys in fall, and other observers have reported it from localities in the southern part of the state. Its possible breeding in the northern part of the state may be suggested, as it is well known to breed among the Adirondacks; and Mr. G. H. 'Tliayer (:02) has even recorded what he believes to have been a Li11coln's Finch seen by him on July 28, I900, at Lake $\mathrm{N}$ ubanusit in Southwestern New Hampshire.

Dates: May 15 to 26 ; September 7 to October 4.

184. Melospiza georgiana (Lath.). Swamp SPARRow.

A rather common spring and fall migrant and a less common and local summer resident. During the summer it is confmed to grassy swamps along streams and lakes. It is common as a breeding bird in many places in southern New Hampshire, but among the White Mountain valleys it seems rare at this season. Mr. F. H. Allen ('S9, p. 78) has recorded it from Moultonboro in the summer, but I know of no other locality where it breeds, in the inmediately adjacent country to the north though several apparently favorable places have been investigated. Mr. C. J. Maynard ('72) states that it breeds at Lake Unbagog. In the Saco valley at Intervale, it appears in some numbers during September with flocks of other migrating sparrows.

Dates: April to Octoler io.

185. Passerella iliaca (Merr.). Fox SPlRkow.

A rather cominon migrant in early spring and late fall. The 
last of the spring migrants pass through the White Mountains by April 23 or thereabonts, and appear again on their sonthward fight in early October.

Dates: March 6 to April 23 ; October 5 to November 7 .

\section{Pipilo erythophthalmus (Linir.). TowneE.}

A not uncommon summer resiclent of the Transition valleys in the southern parts of the state becoming rarer and local towards the White Monntains, to the north of which it appears not to occur. In the lower Connecticut valley this bird is fairly common, and is found also in some numbers throughout the central and southern regions of the state in open bushy lands. North of Lake Winnepesaukee it occurs in bushy, sandy areas in the lowlands. Mr. E. A. Preble finds it abont Ossipee among the sandy "barrens" grown up to bear oak and pitch pine, and I have found it in small numbers in a few similar localites in that vicinity and as far up as North Conway in the Saco valley. Dr. Walter Faxon tells me also of a bird seen by him on June I 7, I 894, near Moosilauke. At Intervale, I have seen the bird but once, when on Sept. 19, I899, a migrant appeared on the edge of the Saco meadows in the early morning.

Dates: May I to October.

18\%. Zamelodia ludoviciana (Linn.). ROSE-BREASTED GROSBEAK.

An uncommon summer resident of the Transition area, entering also to a less extent the sub-Canadian region. A few summer regularly in the White Mountain valleys at least as far up as Intervale, though I have found then more common there in August or September during migration. Mr. G. H. Thayer notes their fondness for potato beetles at Dublin.

Dates: May 12 to September is.

Yote: Guiracal cierulea (Linn.). BLUE Grosbrak.

Miss Mabel C. Berry ('96) records having observed at close range, on May 26, 1894, an adult inale of this species at Fast Derry. The bird was not secured, though the observer felt certain of the identity. It seems safer, however, to await a more positive record before according the bird a place in the list of New Hampshire birds. 
188. Cyanospiza cyanea (Linn.) Indigo BunTing.

A rather common summer resident of the Transition region. In the southern part of the state it is very common in certain localities, and follows the lower valleys well up among the White Mountains. It is also recorded as not common about Lake Unbagog. During September considerable flocks of old birds and fully grown young gather around the weed-grown fields and standing corn, and at Intervale, in the Saco valley. remain until the first of October when the frosts are lieavy. Mr. G. H. Thayer writes me that at Dublin, but few occur so higlı up as $I, 400$ feet.

Dites: May 9 to October I.

189. Piranga erythromelas Vieill. SCARLET TANAGER.

A not nncommon summer resident of the Transition and subCanadian woods. In the White Mountains, I have found it in small numbers on the mountain sides as far as the upper limit of the beech woods, some 2,00o feet. According to Mr. C. J. Maynard, it is rare at Umbagog, and is doubtless wanting in the coniferous forests of the northern part of the state. The males cease singing about the second week in July, and owing to their habit of keeping to the upper regions of the forest trees, are not very frequently observed in late summer. At Intervale, I have noted occasional birds in the beech woods up to September

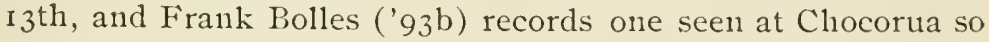
late as the $25^{\text {th }}$ of that month, I89r.

Dates: May 13 to September 25.

Note: Piranga rubra (Linir.). Summet Tanager.

Although this bird has twice been recorded from New Hampshire, once by Mr. C. F. Goodhue, who believed he saw one at Webster ('77a, p. 49), and once by Mr. Ned Dearborn (' 98, p. 27 ), who addnces the testimony of Mr. George Stolworthy of Franklin to the effect that he saw a number of males at that place in the early summer of 1875 , neither of the records seems to stand on a sufficiently definite basis to warrant according the species a place in the present list.

190. Progne subis (Limn.). Purple Martin.

A not uncommon, though local summer resident of the Transition valleys throughout the sonthern and central parts of the 
state. It breeds in the Connecticut valley at least as far up as Colebrook, where Dr. Walter Faxon ('97) has recorded that Mr. William Brewster found a pair in 1896 , nesting under the hood of an electric arc light. I have never found it breeding at Intervale, though two miles farther down the valley at North Conway a small colony annually inhabits a large bird house. Apparently the birds are slowly falling off in point of numbers. Dates: April 19 to Séptember.

\section{Petrochelidon Iunifrons (Say). Criff Swallow.}

A common spring and fall migrant and common local summer resident throughout the lowland districts of the state up to at least 1,500 feet. The birds breed in colonies under the eaves of barns and outbuildings, and the young after leaving the nest are often to be seen in little squads on the roof, where they are fed by their parents. Even after the young are strong on the wing they are still fed occasionally by the old ones, and not infrequently have I observed the parent perform this duty in mid-air, both birds hovering for a second to effect the transfer. Concerning the supposed immigration of this species from the west in the early part of the century, there seems to be no conclusive evidence. Peabody ('4I) states that the earliest information he had of its appearance in New England was from Chief Justice Shaw, who "found it at the White Mountains in the summer of I 816 ." Belknap, writing in 1792 , does not mention it as a bird of New Hampshire.

Dates: April 28 to September I.

19\%. Hirumdo erythrogaster (Bodd.). BARN SWALL.OW.

A common spring, and abundant fall migrant, and fairly common summer resident, nesting throughont the farming districts in the large open barns, up to about 1,500 feet in the White Mountain valleys. It is said to be abundant at Irake Unbagog. In August, the birds gather in large flocks and move southward. At Intervale, one may see them during this month flying leisurely down the valley at all hours of the day, and several times I have seen an entire flock of some 25 birds pause in 
their flight to chase a passing hawk. Only a few are seen among the White Monntains after August, thongh I have noted single stragglers at Intervale so late as September 12, I900, and in IS9S, a single bird on September $2 \mathrm{I}$, the day being cold, and Mt. Washington's snmmit white with snow.

Dates: April 24 to September 21.

193. Tachycineta bicolor (Vieill.). TREE SWALLOW.

A common spring and fall migrant and less conmon summer resident. These bircls arrive in central New Hampshire in early April before the snow is off the ground and from one to three or more pairs are generally found abont the smaller towns and villages in summer. At Intervale, I have rarely found more than one pair nesting in the village. In the forest of water-killed trees at the month of the Androscoggin River, Lake Umbagog, Mr. William Brewster ('76b) has recorded that "multitudes" were found "occupying deserted nests of the smaller Woodpeckers."

Dates: March 23 (Hampton Falls) to September.

\section{Riparia riparia (Linn.). Bank Swallow.}

A common spring and fall migrant and a locally abundant summer resident, nesting in colonies where steep banks of sand occur along the rivers. The breeding birds often go far afield in search of food, and I have frequently seen individuals flying over the Saco valley at least a mile and a half from the nesting colony. It is interesting, in watching a large colony, to observe the apparent precision with which each bird enters its proper burrow, and only on rare occasions iiave I seen a bird hesitate for a second before picking out its own burrow. This is the first of our swallows to leave, and anong the White Mountain valleys the breeding colonies break 11 and disappear by the middle of July, and except on one occasion (a single bird seen Ang. I I, I899) I have never observed the birds at Intervale after July. Mr. William Brewster, however, ('9Sb) notes them with flocks of other swallows at the lower end of Lake Umbagog on Aug. 22, 1896. As pointed out by Mr. Ned Dearborn, ('98) these swallows will often dig their burrows in a newly-ex- 
cavated sand pit, but after a single season desert the locality altogether. I have often observed the same thing in various places and attribute it to a change in the texture of the sand near the face of the cut due to the drying ont of the water on the newly-exposed front, so that it would cave in more readily if a burrow were dug.

Dates: May to August 24.

\section{Ampelis garulus Linn. Boheman Waxwryg.}

An extremely rare winter visitant. This bird is frequently reported by amateur observers, who, as their judgment grows with later experience, are led to expunge their record. There appears at present to be 110 valid published record for the occurrence of this species in the state, but Dr. W. H. Fox informs me that in the early part of r88o, O. H. Phillips, a taxidermist. took specimens near Nashua. Mr. W. E. Cram writes me he has observed it at Hampton Falls on February I 7 and 21, I897,

\section{Ampelis cedrorum (Vieill.). CEDAR VAxwring.}

A common spring and fall migrant and summer resident; rarely wintering in the southeastern portion of the state. Although these birds breed mainly in the open Transition and sub-Canadian regions, they are great wanderers, and small flocks of from 3 to 6 birds are not infrequently observed during summer crossing the Presidential range, or stopping for a few moments at the higher levels, as at Carter Lakes ( 3,360 feet), and Halfway House $(3,840$ feet), to pass on again shortly. In the White Mountain valleys they nest about the middle of July, and the young are soon on the wing. During September they quickly gather into large flocks about the wild cherry trees, preparatory to migrating southward. Mr. Ned Dearborn (: o ) records that a flock of ten birds wintered at Durham during the season of I899-I900, a circumstance which appears to be quite unusual. In eastern Massschusetts there is regularly a wave of northbound migrants abont the end of January, this movement lasting into March, after which there comes a second wave in late May. Apparently this first wave has spent its energy by the time it reaches central New Hampshire. Rarely this first 
flight reaches the central part of the state in Jannary; thus Mr. C. F. Goodhue ('85) notes a flock of 20 or more at Webster in Jannary, 1878. By February or March, the birds appear irregularly in the lower portions of the state, though often observers in the central connties do not see them till late May, i. e., during the second wave. The linits and dates of these peculiar movements will bear a much more thorough working out. The fall migrants have nsnally left by October.

\section{9\%. Lanius borealis Vieill. NORTHERN SHRIKE.}

A rather common late fall migrant and winter resident thpoughout the state, occurring as high at least as 2,000 feet in the White Mountains during winter.

Dates: November 12 to April.

198. Lanius ludovicianus Linn. LOGGERHEAD SHRIKE.

A rather rare and local summer resident in the Transition valleys at least as far north as the White Mountains, and the upper Connecticut valley; accidental in winter. In view of the general lack of definite published breeding data for this species, it may be well to detail the records for New Hanpshire as far as possible. The bird has been observed at the following localities in the state: Charlestown, Mr. W. M. Buswell has observed a pair for at least two seasons in the same yard, and on April 26, r 898 , took their nest and six eggs. This nest was nearly completed by April 8, and contained two eggs on the 2ist. The earliest date at which he has observed the bird in spring is March 20. Concord, near this town a specimen was obtained by Mr. C. F. Goodhue, on January 20, 1879 , and identified and recorded by Mr. Ruthven Deane ('79). Hampton Falls, one was observed by Mr. W. Is. Cram on August 20, I899. Hanover, a pair is recorded by Mr. E. B. Frost ('85) to have nested in a fir tree in a person's yard during the season of 1885 . The birds were first seen on April I6, and by May 4th, the nest had been built and six eggs laid. Both birds were shot for identification. Mr. Frost, in a letter to the writer, adds that a nest with six young was fonnd at Hanover on May 30, 1884, and that he 
knew of another at about the same time. Also on May 17, I897, on the Vermont side of the Connecticut river, a nest containing one egg and four young birds was found by Mrs. Frost, and in I 898 , the birds were noticed near the same place. Hollis, one seen by Dr. W. H. Fox on September I, I885. Intervale, I have twice observed the bird in the Saco valley here; once on August 25, 1897, when a single bird was seen for a short time on the meadows, and again on August 9, 1899, when I watched one for part of an afternoon as it stayed about an old apple orchard near the river valley. Possibly a pair may have nested here earlier in the season. Jefferson, in an interesting letter on birds observed in this vicinity, Mr. H. W. Wright tells he that " it has been breeding for several years within town limits. A friend living on the road to Jefferson $\mathrm{Hill}$, when I discovered a family of shrikes about his pasture, told me they had nested in the same eln tree in that pasture for 4 or 5 years. In I 899 , we observed them whenever we drove by throughout the season. This year (I900) they nested farther back and were seen only occasionally on the roadside. I have ohserved a pair or family at three or four other points, in driving, in this vicinity." Lancaster, Mr. F. B. Spaulding finds it a regular summer resident here, where it arrives early and breeds about the first of May. Northficld, in September, r897, Mr. Ned Dearborn ('98, p. 218) observed one at this town. Tamworth, a single bird was observed on August I6, r898, by Dr. A. L. Reaglı (see' Howe, : or, p. 44). Tilton, according to Mr. Ned Dearborn ('98, p. 28) a nest with eggs was discovered here by Mr. G. H. Davis, in May, I 897 .

From the foregoing, it is plain that this shrike is most com11101 in the valleys of the Connecticut and its larger tributaries, by which it reaches the conntry slightly north of the White Mountains.

Dates: ( January 20, '79) March 20 to September.

199. Vireo olivaceus (Lin11.). RED-YYYA VIRFO.

A connuon summer resident throughout the Transition and st1b-Canadian areas, being found from the sliade trees of the vil- 
lage streets up to about 3,000 feet in the mixed forests on the White Mountains. It is also common to the north of these monntains, as at Lake Umbagog. At Intervale, I have on one or two occasions seen single birds on the wire fences, which cross the Saco meadows, feeding on crickets which they obtained on the edge of a farni-road, and carried to the fence to eat. Most of then leare the latitude of the White Monntains by the middle of September, though Dr. Walter Faxon informs me that he saw three on September 30, 1895, at Warren.

Dates: May $S$ to September 30.

\section{Vireo philadelphicus (Cass.). Philadelphia} VIREO.

A rare spring and fall migrant, and in the northern part of the state a rather rare summer resident. To Mr. William Brewster, we are clinefly indebted for our knowledge of this species as a summer bird of New Hampshire. About Lake Umbagog, this gentleman and Mr. Ruthven Deane (' 76 ) secured in all, three specimens, on the $3 \mathrm{~d}$ and 4 th of June, 1872 . Near the same spot, Mr. Brewster ('So) secured on August 29, I874, three more specimens and a fourth on August 3 rst, these being all "young birds in freshly assumed but quite perfect fall dress." On May 29, 1876, another was taken at Umbagog, and two more on May 3 Ist, and three years later, on May 27 , I879, a mated pair was shot. From Umbagog, Mr. Brewster ('8o) states that he traced them westward to Dixville Notch in northwestern New Hampshire, where "they were noted in greater numbers than elsewhere, and on June roth several pairs were found in the open birch groves about the 'Dix House,' just beyond the Notch." He further notes that although these birds arrive at Umbagog during the last of May or first week of June, they remain silent until the breeding season has fairly begun, when they are quite as indefatigable singers as the Redeyed Vireos, and are then found generally distributed throughout the less heavily wooded areas. Mr. Ralph Hoffmant has also noted the bird in the Dixville Notcln in the breeding season, in I9o3. The only White Mountain record of this bird in 
the breeding season is that of Mr. Bradford Torrey ('90, p. 25I) who, in company with Dr. Walter Faxon, observed one singing "by the roadside in the valley," at Franconia, on June I6, 1889 , and repeatedly in the same place on subsequent days. The bird acted as if settled there, but no nest was found. 'The following instances of its occurrence as a migrant elsewhere in the state are detailed as of interest: Chocorua, where Mr. F. H. Allen informs me he observed a pair on June 5, 1900, probably late migrants; Frank Bolles ('93b, p. 39) also records having once observed it there in migration. Dublin, one taken September 29, I 899 , and a second at the sane season in I 900 by Mr. G. H. Thayer $(: 03)$ who records seeing others at Dublin on several occasions in fall; near Fitzwilliam, one obtained on May 27. I897, as I am informed by Mr. G. H. Thayer. Franconia, one bird seen September 23d and another September 26, 1900, by Mr. Bradford Torrey; Hollis, one recorded by Dr. W. H. Fox ('77) as shot on May' 26, I876, by' a Mr. A. F. Eaton, while it was "feeding in company with two other birds of the same kind, in some low oak bushes;" Intervale, I observed a single bird anong some small elms in the Saco valley on Aug. 26, 1899 , an early fall migrant doubtless.

Dates: Mray 26 to September 29.

201. Vireo gilvus (Vieill.). WARBLING VIREO.

An uncommon summer resident within the Transition areas of the state, and during the nesting season is usually confined to the big elm trees of the village streets. In the White Mountain valleys, the bird is rare so far up as Intervale, and for several years I have never known more than one or two pairs to summer in the big elms of the village. What I presume to be the same pair of birds has for at least three successive seasons lived among a group of elms near our house, and although after the young were off, I have several times secn the birds in the open valley at a considerable distance from their nesting site, nevertheless the male is now and then to be heard singing in the early norning from the same elms even into the second week of September. Apparently this species is rare or generally absent to the norti of the White Monntains, though Mr. 
F. B. Spaulding reports it from Lancaster, in the Connecticut valley. Dr. Walter Faxon has found it also breeding at Franconia.

Dates: May 3 to September 17.

\section{0:. Vireo flavifrons Vieill. YEL,OW-THROATED} VIREO.

An unronmon summer resident in the Transition valleys of the lower part of the state. At Hollis, Dr. W. H. Fox writes that it is common in summer, and it also occurs regularly on the coast in small numbers. About Manchester it is said to be common, and ustrally found about towns. Farther north in central New Hampshire it becomes rarer; at Bridgewater, Mr. F. H. Allen ('89) has observed it, and Mrs. E. E. Webster writes me of one seen at Franklin Falls in May, r 899, while Mr. C. F. Goodhue notes it as breeding about Webster. I have no record of it north of Lake Winnepesaukee in the central part of the state, where, however, it may be of casual occurrence. Mr. Bradford Torrey (:oo, p. ${ }_{3} 8$ ) records a single bird singing on June 3, 1899, in a sugar maple grove at Franconia, which is the first time, in all his observations in that region, that he has seen the bird there. This straggler may have reached Franconia by way of the Pemigewasset valley, but more probably by the Connecticut basin, where the bird is a regular summer resident as far up at least as the vicinity of Hanover, and according to Mr. R. H. Howe, Junior, (:02, p. 19) it has even been recorded from St. Johusbury, Vt., on a northern tributary of the Connecticut.

Dates: May 8 to September.

'203. Vireo solitarius (Wils.). BLUE-HEAdEd VIREO.

An uncommon, though generally distributed summer resident, throughout the sub-Canadian areas of the state. On our extreme southeast, Dr. IV. H. Fox finds it a rare breeding bird at Hollis, but on the higher land farther west, about Mt. Monadnock, and northward along the eastern rim of the Connecticut valley and throughout the mixed woods of the central and northern parts of the state it is fairly common, nesting up to about 
3,000 feet in the White Monntains. Apparently the great freeze of 899 killed numbers of the early migrants, and in the White Nountains especially, I have noticed an apparent diminution in their numbers in the two following seasons.

Dates: April 29 to October 7 .

Note: Vireo noveboracensis (Gmel.). WhITE-Eyed VIREo.

This species probably reaches the extreme southwestern part of the state at times, and has beeu recorded by MIr. F. W. Batchelder (: o, p. 133) to have bred near Lake Massabesic, Manchester, in IS99, and preriously on the Hooksett Road in the sane town. Mr. Ned Dearborn (' 98, p. 29) includes it among the birds of Belknap and Merrimack Connties on the authority of a Mr. George Stolworthy but this record is perhaps to be questioned. Mr. W. E. Cram of Ilampton Falls also writes me that lie is cunfident he has once observed it at that place. At present, however, it seems safer to exclude the bird from the New Hampshire list awaiting an undoubted record.

\section{Vireo bellii Aud. BeLL'S VIREO.}

An accidental visitant from the interior. Mr. William Brewster $(: O I)$ records that $\mathrm{Mr}$. Ned Dearborn, while driving along a country road in Durham, on Norember 19, I897, observed a small bird hopping about some poison-iry vines which had overrun a stone wall. Mr. Dearborn shot the bird and subnitted it to Mr. Brewster for examination, and the latter states that it proves to be a perfectly typical example of this species.

\section{Mniotilta varia (Linn.). BI $A \mathrm{CK}^{\mathrm{A}}$ AND WHTt:} WARBLER.

A common spring and fall 11igrant and less common summer resident througlnout the Transition and sub-Canadian woods. Among the White Nountains it appears to be quite absent in the breeding season above the 3,000 foot level, and is also rare or wanting in the balsam and spruce forests of the northern part of the state. About Intervale, I have found it common all summer in the lowland woods of mixed or deciduous growth.

Dates: April zo to September 29.

Note: II elmithreus vermivolus (Gme1.). WORM-JATING WARBLER.

A specimen is recorded as seen at Mranchester on Oct. I, I900, by a Mirs. A. A. Alacleod (:00, p. 102) but the record is not properly substantiated. 
206. Helmintlophila clngsoptera (Limn.). Gon,1) WINGED WARBLER .

A rare migrant, and probable summer resident in the extreme southeastern part of the state. Althougl no actual instance of its breeding in the state is known to me, Mr. IV. Ii. Cran writes that he took a specinen at Hampton Falls in May, I887; Mr. G. H. Thayer writes that he has observed it once in early summer near Jaffrey; and local observers report (Proc. Manchester Inst. Arts \& Sci., Vol. II, p. 8o) that a few were observed in May, r9oo. at Mancliester. Mr. Ralph Hoffmann also informs me that a fine male was noticed in late May and early June, I902, by Dr. IV. R. Varick at Concord, where there may have been a breeding pair.

20\%. Helminthophila rubricapilla (Wils.). NASHVIJ,I,E WARBLIER.

A common spring and fall migrant and rather common summer resident. It is of general distribution in damp bushy localities throughout most of the state and is common in certain portions of southwestern New Hampshire. Among the White Mountains it is scattered all over the higher peaks in the Can $x$ dian zone, and is fairly common up to the limit of small tree growth, or nearly 4.500 feet, and I have repeatedly noted birds at the head of 'Tuckerman's Ravine on Mt. Washington, in King's Ravine and elsewhere on the great range. During a trip over the Carter range, June 13 to 16 , r902, a large number of these birds was observed. They seemed to be very evenly distributed above 3,000 feet, and showed a preference for the birches, then just in bud, scattered through the balsam forest.

Dates: May 4 to September I3.

208. Helminthophila celata (SAY). ORANGE-CROWNED WARBIER.

An accidental visitant, for which there is but a single valid record:-Hollis, a single bird taken May 16,1876 , by Dr. IV. H. Fox ('76). Dr. Fox informs me that the spcimen has been exanined and thoroughly identified by competent authorities. The record by Mr. Jolun Murdoch (' 78 ) of a bird taken at Isles of Shoals has been sliown to be a misidentification. 
209. Helminthophila peregrina (Wils.). TENNESSEE WARBLER .

A rare spring and fall migrant and in the upper Canadian regions of the northern part of the state au uncommon summer resident. About Lake Umbagog the bird was stated by Mr. C. J. Maynard (' 72 ) to be common, and more recently, Mr. William Brewster is quoted as saying that it is there found during the breeding season, generally in larch swamps, but sometimes among coniferous growths on the mountain sides. Among the White Mountains it is a rare and local stmmer resident. Dr. Walter Faxon ('89) records that in ${ }^{8} 887$ he and Mr. Bradford Torrey found two males in full song throughout the breecling season, "in some pasture land largely grown up to black spruce in Franconia, * *** at a high level (some distance above the Profile House Farm)." In late May, i 888, the bird was detected in the same place, and " also in an extensive larch swamp in the lower part of the same town, where Mr. Torrey found it againin the latter part of the following month." Mr. Torrey has several times since recorded the bird from this locality. Elsewhere among the White Mountains it has not been detected in the breeding season so far as I am aware. In migrations the bird has been observed once in late May, I897, at Dublin, by Mr. G. H. Thayer; one was captured on the Isles of Shoals Sept. 9, I877, and recorded by Mr. John Murdoch ('78) on supposedly good authority as $H$. celata, but Mr. William Brewster ('82) who later examined the specimen pronounced it to be pergrina; one was noted at 4,000 feet on Mt. Adams on Sept. 2, i884, by Dr. A. P. Chadbourne ('87); and Mr. C. F. Goodlnue has taken it at Webster. According to Mr. F. W. Batchelder (:oo, p. 133) it is a "rare transient visitant" at Manchester.

Dates: May 20 to Septeuber 9.

\section{Compsothlypis americana usnero Brewst.} NORTHERN PARULA WARBI,ER.

A common spring and fall migrant, and a not uncommon summer resident of the thick, sub-Canadian forests, thougl found usually in spruce and hemlock woods where there is more 
or less Usnea ; it occurs frequently, however, in growths where there seens to be little of this moss, and delights to feed among red oaks. I have not observed it above 2,500 feet in the White Monntains, and it is hardly a common bird in the coniferous woods of that region.

Dates: May 3 to October $x$.

\section{Dendroica tigrina (Gmel.). CAPE MAY WAR- BI,ER.}

A rare spring and fall migrant in the central and southern parts of the state, and an irregillar summer resident of the Canadian forests to the north of the White Mountains. Mr. C. J. Maynard ('72) records it as formerly common at Umbagog, breeding in the thick evergreen woods, and according to Mr. Wm. Brewster ('95) it was a really abundant summer resident there from I87I-'75, but before I879, had quite deserted the region. I do not know of its occurrence in summer among the White Mountains, though Mr. Bradford Torrey (:oo) records that he observed a male in full song at the "Landaff Larcli Swamp " among the Franconias, almost daily from the $22 \mathrm{~d}$ of IIay to the 3 d of June, I 899 , after which date he was called away. Mr. G. H. Thayer writes of having twice observed the bird in fail at Dubliu. Local observers record in the Proceedings of the Manchester Institute of Arts and Sciences, Vol. II, p. 82 , that it was observed in some numbers at Manchester during the phenomenal warbler migration of May, r9oo.

Dates: May ro to September.

21\%. Dendroica restiva (Gmel.). YFLLOW WARBLER.

A not uncommon summer resident in the 'Transition valleys of the southern and western parts of the state, but rare or absent in the White Mountain valleys and northward. In the Merrimack valley the bird is common at least as far up as Concord, and elsewhere in the southern valleys it is of general occurrence. North of Lake IVimepesankee it is very local. About Newfound Lake a small number annually breed, and at Ossipee, Mr. E. A. Preble has once found it nesting. Dr. Walter Faxon found a single pair in the willows on Gale river 
among the Franconias about the summer of r886, and Dr. J. A. Allen (Faxon \& Allen, '88) records them at Bethleham and Franconia in 1874 , though apparently the bird is now very rare or wholly absent from these regions in summer. I have never seen it about Intervale save in fall, although there seems to be suitable country for it. On September I I, i 899, I noted two in some bushes on the Saco meadows at Intervale, but have never seen others there. In the Connecticut valley the bird is fairly common at least as far up as Lancaster, where both Mr. F. B. Spaulding and Mr. H. W. Wright have found it in summer, and the latter gentleman observed a single bird singing in the western part of Jefferson on Aug. 12, I90I. A few also work up the side valleys farther south to some distance; thus Mr. G. H. Thayer has found it in Marlboro commonly, while farther up at Dublin it is rare.

Dates: May 9 to September II.

213. Dendroica crerulescens (Gmel.). BLACK-THRoATFD BLUE WARBLER.

A fairly common summer resident of the rich, sub-Canadian woods, inhabiting the denser undergrowth along the forest brooks. Dr. W. H. Fox writes me that it breeds rarely at Hollis on our southeastern border, and Mr. G. H. Thayer finds it about Monadnock rather commonly. In central New Hampshire it is fairly common locally. Among the White Mountains it occurs commonly up to the 3,000 foot limit, above which I have rarely found it. On June 2I, I900, I observed a single male singing by the lake in Carter Notch at the altitnde of 3,360 feet. The males continue to sing at intervals long after the breeding season, and I have heard their song in the woods at Intervale $u$ intil the 17 th of September.

Dates : May ro to October ro.

214. Dendroica coronata (Limin.). MYRTLF WARBLFR.

A very common spring and fall migrant, and a common summer resident of the Canadian fanna. It breeds rather sparingly in coniferous growth on the hills of the southwestern part of the state and along the height of land which bounds the Con- 
necticut river basin on the east. I have no certain evidence of its breeding in the southeastern section of the state, though it may do so locally, and Dr. W. H. Fox lias recorded ('84) taking an adult nuale at Hollis on June 25, I883. Anong the White Monntains, it is found to breed sparingly anong the white pines in the river valleys so low as 520 feet at Intervale, while higher on the mountains it is fairly common up to 3,00o feet above which it is practically the only Dendroica, except $D$. striata, to occnr in any numbers. To the limit of scrub growth, at 4,800 or 5,000 feet, it is generally distributed, and I have noted it on numerous occasions at these upper levels on the Presidential and Carter ranges. In September, this species is often found in the valleys in considerable numbers, accompanying the little flocks of Bluebirds and Chipping Sparrows, and frequently is observed feeding with them on the ground, instead of frequenting the woods with the hordes of other migrating warblers.

Dates: Spring migration, April 23 to May 28 ; Summer; fall migration, September to October 23.

215. Dendroica maculosa (Gmel.). MAGNolia IVARBIER.

A common spring and fall migrant, and a rather common summer resident of the sub-Canadian fauna. It breeds in small numbers among the spruce woods of Mt. Monadnock and local1y elsewhere in southern and western New Hampshire, being here very strictly confined to the spruce growth. Among the White Mountains, it is common along the streams and in the damp thickets of spruce, hemlock, and fir, with an undergrowth of deciduous bushes, and reaches the altitude of 3,000 feet on the nountain sides, above which, however, it is very rare or entirely wanting. Mr. William Brewster ('77a) gives an acconnt of the habits of this bird as observed by him in New England, wherein he states that he has found it generally distributed over high and low conntry. alike, to the north of the White Mountains, and notes its arrival at Unbagog already by the 25 th of May, I876, while yet " not a leaf had unfolded, even in the most 
sheltered places, and snow lay in large masses everywhere in the hollows and on northern exposures."

Dates : May 9 to Octocer 3 .

\section{Dendroica pensylvanica (Limn.). Chestrut- SIDEN WARBLER.}

A summer resident of the Transition area, common in the southern parts of the state, but becoming somewhat less plentiful among the White Mountain valleys. Mr. Maynard (' 72 ) reports it as "not very abundant" at Umbagog, where also it breeds. It is generally confined to open bushy fields, or clearings grown up with sprouts and bushes. Among the White Mountains it is found mostly in the valley bottoms, but is quick to take advantage of sprout growth in newly-made clearings even far in the woods. Thus during the winter of I898-99, a considerable area of beech woods was cut on the west slope of MIt. Bartlett at about I, ooo feet, and during the following year there sprang up a considerable growth of sprouts. The next spring a pair of Chestnut-sided Warblers was found to have ensconced themselves there. In another case, a pair was found at slightly over 2,000 feet on the Carter Notch trail, where a bushy growth had arisen in a clearing made in the depth of the forest abont a lumber camp. Mr. E. A. Preble has also observed about Ossipee the same readiness of these birds to quickly occupy the young growth following the clearing off of woodland, a fact which slows that in the keen struggle for existence, this species is not slow to take advantage of an increase in the available living area.

Dites : May 6 to September 25.

\section{1\%. Dendroica castanea (Wils.). BAY-BKEASTED} WARBLER.

A rather rare spring and fall inigrant in the southern parts of the state, but sometimes common, as in May, I9or. In the White Monntains and northward it is a fairly common summer resident mainly of the upper Canadian zone. The range of this species in summer overlaps that of the Black-poll Warbler for about I,Ooo feet, and extends below it to nearly an equal 
amonnt. Thus one finds breeding birds at an altitude of from I, Soo feet in rich, dan1p coniferous woods on sonthern exposures, np to about 4, ooo feet anong the small balsam timber. The two birds in respect to their ranges are perhaps somewhat comparable to the Olive-backed and the Bicknell's 'Tlırushes, the former inhabiting the lower altitudes and ranging upward into the stronghold of the latter. Mr. C. J. Maynard fonnd this a comnon breeding bird at Lake Umbagog thirty years ago, though apparently he did not observe $D$. striata breeding there. Mr. F. H. Allen tells me that on the Sandwich range he has found the bird common in the breeding season in the vicinity of Waterville. Mr. M. Chamberlain ('9r, Vol. I, p. 238) has also recorded that a nest was found on Mt. Chocorua by Frank Bolles, but the identification appears not to have been certain. South of this range, I have no actual evidence of the breeding of this species, but Mr. C. F. Goodhue ('77a, p. 33) has recorded that young birds hardly able to fly and still fed by their parents, were observed at Webster in the latter part of July about i875. Mr. G. H. Thayer also writes me that he observed a pair in late May, 1897 , in a deep hemlock and deciduous wood on Monadnock, with nesting material in their bills, and states that they showed great anxiety when their vicinity was approached. Whether or no the birds did nest was not ascertained. In fall, owing to the difficulty of distinguishing this species from the Black-poll Warbler, observations are less easy to make, but I an inclined to think they migrate nore or less with the latter, and I have taken specimens in the woods at 2,000 feet from mixed flocks of warblers. In the month of May, I900, owing to the occurrence of cold waves, these and other northbound migrants lingered in unusual numbers throughout southern New England instead of passing by to their breeding grounds.

Dates: May i4 to 28; Summer to September.

218. Dendroica striata (Forst.). B1,ACK-POLL, WARBI,EK.

A very common spring and fall migrant over the sonthern parts of the state, and a common summer resident of the upper Canadian zone on the White Mulnitains and northward. On 
the higher mountains of the outlying Sandwich range, which includes several peaks of 4,000 feet or over, Mr. F. H. Allen has found this species in summer and in this same region has noted it in the Mad River Notch at Greeley's Ponds (2,00o feet) and in small numbers as low as $I, 500$ feet near Waterville. Frank Bolles ('93b) also mentions having come upon a pair of these birds on July, I4, on a high ridge of Chocorua. Among the White Mountains, the birds are found througliout the damp balsam forest above 3 , 000 feet on southern slopes, though on the north sides of the mountains they breed at a much lower altitude, following down the cool monntain streamlets. This influence of slope exposure on distribution was well seen in a walk tirrough the Pinkham Notch on June 23, r9oo. Starting at a point below the Glen House on the north side of the divide, the road gradually rises until the heiglit of 2,00o feet is reached and it then decends on the southern slope of the divide, towards the Saco valley. On the north side of the divide, I noted a number of Black-poll Warblers on this walk from an altitude of 1,500 feet to the top of the water shed, 2,000 feet at the highway. They were among the fir balsams and spruces by the roadside in the valley of the West Branch of the Peabody river which flows out from the Great Gulf. Not a Black-poll was heard or seen on the south side of the divide, nor was the vegetation so well suited to their'requirements, being 111ostly of mixed and deciduous growth. The 3,000 foot limit is about as far down on the south slopes of the mountains as the bird breeds, except of course where peculiar local conditions obtain; and from that height up to the linit of scrub growth, at from 4,800 to 5,000 feet, it is one of the most cliaracteristic birds of the mountain-top fauna. Most of the Black-polls cease singing by August, thougln on trips into their conntry during the last week of that montli, I liave heard a few still in song. On September 14, 1900, while in camp at Carter Notch $(3,360$ feet $)$ where the birds are com11non all st1mmer, I observed an individual in the fall plumage as it sang again and again among the stunted fir trees; and during a long walk over the range on the same day two or three others were heard singing. On the following morning, September 15 th, what may have been the same bird as 
previonsly noted, was again singing with all its springtime vigor about the camp. I also heard a few singing in early September, 1901, while on a trip over this range. These I take to be the resident birds still on their breeding grounds, as I have never observed the migrants at low altitudes singing in fall. Under the head of Migration, I have detailed some observations on the interesting movements of the Black-poll Warblers, and it may be again remarked that they appear to migrate along the mountain tops in fall, keeping generally above 2,000 feet or so, and uncommonly appearing in the valley bottoms at this season among the White Mountains, though after the central parts of the state are reached, they flood the low country as we are accustomed to see in Massachusetts. In the lower part of the state, the spring migration is over by early June, and the fall migrants again appear in late August or early September.

Dates: May 8 to October Io.

219. Dendroica blackburnire (Gmel.). BLACKBLRNIAN WARBLER.

A rather common summer resident of the sub-Canadian woods. especially those of mixed hemlock and deciduous growth. In the southern part of the state, Dr. W. H. Fox writes that it breeds at Hollis, and it is well known to nest about Mt. Monadnock and northward along the ridge forming the easterin rim of the Connecticut valley basin. In the White Mountain region, it is conmon in the white pine and spruce woods up to about 3,000 feet, but above this level only a few scattering pairs occur. Dr. A. P. Chadbourne (' 87 ) records seeing a single bird at 3,800 feet on Mt. Washington on July 8, I 886 .

Dates: May 4 to September ro.

220. Dendroica virens (Gmel.). BLACK-THROATHD GREEN WAKBLER .

A rery common spring and fall migrant and a common summer resident, breeding most plentifully in the pine and spruce wooks of the sub-Canadian area. In such growths, it is very common in the White Mountains up to abont 2,000 feet. A few pairs penetrate still farther wp the mountain sides into the 
lower edge of the upper-Canadian fir growth. Thus I have observed a bird singing by the lakes in the Carter Notch $(3.360$ feet) on June 20, I900, and another by Hermit Lake ( 3,800 feet) on Mt. Washington on the same day.

Dates: (April 26) May I to October 5.

\section{Dendroica vigorsii (Aud.). PINE WARBLER.}

A rather common'spring and fall migrant in the sonthern part of the state, and as a summer resident not uncommon locally in the Transition valleys and lowlands as far north as the White Mountains. It is largely confined during the breeding season to groves of pitch pine (Pinus rigida) though where these trees are not to be had, it will occasionally take to the white pines (Pinus strobus). In the Connecticut valley, Mr. R. Hoffmam has found this bird in small numbers as far up at least as Cornish, during the summer. In central and southern New Hampshire, it is not rare in the breeding season, but farther north, especially in the lowlands about Ossipee, where, on a large tract of dry sandy soil there is an extensive growth of pitch pines, the bird is fairly common. Here, on April 2I, I90o, before the snow was off the ground, I found a few of these Warblers singing, they having evidently just arrived. Still farther up the state, a few are fonnd every year in the dry pine woods at North Conway and Intervale in the Saco valley. At Intervale three or four pairs summer annually in the white pine woods at about 500 feet, there being 110 growth of pitch pine of any size. In the fall migration I have never found the bird here in any numbers, though single ones are of occasional occurrence with the flocks of Chickadees and other small birds in the woods, or eren with the Chipping Sparrows and Bluebirds on the open meadow lands till late Septcmber, and I have heard occasional birds singing up to the $22 \mathrm{~d}$ of that month.

Dates: April 2I to September 25.

221. Dendroica palmarum (GMel.). PAI,M WARBLER.

An uncommon fall migrant. Dr. A. P. Chadbourne ('84) was the first to record its presence in the state on the strength of a specimen shot at Shelbume, in the Androscoggin valley, on 
September I6, i 884. This bird was in company with a large flock of Warblers, Chickadees and other small birds among some low birches by the roadside. In the Saco valley at Intervale, I have found this species in small numbers usually in company with flocks of Bluebirds, Chipping Sparrows and Myrtle Warblers on the meadows, and have taken specimens between the 8th and i 4 th of September. Its reported presence at Manchester in spring is doubtless an error (Proc. Manchester Inst. Arts \& Sci., Vol. H, p. 82, I90r).

Dates: September 8 to 16.

¿23. Dendroica palmarum hypochrysea Ridgw. YELLOW PALM WARBLER.

A migrant, common in spring and less common in fall. This bird appears in the White Mountain valleys after the middle of September, and usually is found on the intervales in company with small flocks of Chipping Sparrows and Bluebirds.

Dates : April I 3 to May to; September 16 to October 9.

224. Dendroica discolor (Vieill.). PratrIE WARblek.

A very rare summer resident in the Transition valley bottoms of the sottheastern part of the state. Two nests and an egg, taken at Northfield about i 880 , have been recorded as belonging to this species, by Mr. F. H. Herrick ('83) who identified the specimens. The identification, in the light of our present knowledge, cannot, however, be considered as conclusive evidence that the Prairie Warbler occurs in summer so far north in the state. H. D. Minot's statement (' 76$)$ that the Prairie Warbler occitrs at Bethlehen among the White Mountains, is generally discredited, and doubtless with reason. The only anthentic records for the state appear to be the following : - Hollis, three birds taken by Dr. W. H. Fox, an adult male June 28, I884, " in company of half grown yonng," one bird unsexed, shot August 23, I876, and an adult female taken September 4, I 876 ; Manchester, a small colony is reported as found among an extensive growth of scrub pines and oaks in the early summer 
of rgor. The birds were observed here by several persons, and also recorded by "Pinfeather Ornithologist" (:or, p. 33).

225. Seiurus amocapillus (Limn.). OVEN-BIRD.

A common summer resident of the Transition and sub-Canadian areas, most plentiful in the rich shady woods of mixed growth, which it inhabits in the White Monntains up to nearly 3,000 feet. A few linger among the monntains until the last of September, and Dr: W. Faxon tells me that he observed one at Warren on the late date of October 2, I 895.

Dates : May 4 to October 2.

\section{Seiurus noveboracensis (Gmel.). WATER-} Thrush.

A rather common spring and fall migrant and less common summer resident in the thick swamps of the Canadian fauna. It is said to be a common breeding bird about Lake Umbagog, and in the upper Canadian woods of the White Monntains it is found in summer about the cold streamlets on the mountains, or at lower elevations in wooded swamps. Mr. E. A. Preble has noted it as fairly common in such localities in the neighborhood of Ossipee. Mr. G. H. Thliayer informs me that in a small wood swamp near Dublin, he has annually found a pair, and believes they breed there. At Intervale, I have rarely found the bird in June in the lowlands, and as early as the roth of July, single individuals appear in the valley along the edges of shaded pools and brooks, whither they may liave come from the immediate neighborhood.

Dates : May I5 to September 2I.

Note: Seiurus motacilla (Vieill.). Lourstana Watre-Thrush.

Mr. G. II. Thayer (:02) records having observed on Aug. 19, I9or, at Dublin, a bird which he feels convinced was of this species, though he admits that the record cannot be considered as more than an expression of his own conviction.

$22 \%$ Geothlypis agilis (IVils.). Connfeticut WakBI, I:R.

A rare fall migrant of ratler irregular occurrence, sometimes appearing rather commonly for a few days. Mr. C. F. Good- 
htie has observed the bird at Webster on several occasions. Elsewhere in the state, Dr. A. P. Chadbourne ('85) has recorded a female shot on September 14, 1884, on Mt. Baldcap in the town of Success, at an altitude of about 800 feet. Mr. G. H. Thayer writes me of onc observed at Dublin on October 3, I 899. One was also shot by Mr. R. H. Howe, Junior, on September 6 , I899, at an altitude of about 2,000 feet on the Carter Notch trail, Jackson.

Dates: September 6 to October 3.

\section{Geothlypis philadelphia (Wils.). Mourning} WARBIER .

A not uncommon summer resident, from the White Mountain valleys northward, being mainly confined to the tangles of bushes, grapevines, and blackberry canes on the edges of woods or along the mountain brooks; as a migrant, it is only rarely seen in the southern part of the state. It is said to be common about Lake Umbagog in summer and Dr. Walter Faxon has found it in small numbers during the breeding season about Mt. Moosilauke and North Woodstock. At Intervale, during the summer of 1899 , three pairs bred in bushy spots on the outskirts of a sugar maple grove by the Saco river, the same grove, it may be added, that harbored a pair of Screech Owls and a Wood Thrush. These three pairs I observed almost daily for a large part of the summer. The song period was practically over by the middle of July, but the birds still lingered about their chosen locality until early September. During the first twelve days of July, I ocrasionally heard the males sing a flight song corresponding to the Maryland Yellow-throat's. This was usually given as the bird flew slantingly dow11ward from a height of some 20 feet, though on one occasion, a bird after a period of silence, suddenly flew out from the bushes in which it had been concealed, nearly straight upward toward a bare limb of a white maple some 40 feet from the ground. Just before it reached the branch it burst into a short, ecstatic song and then settled on the chosen perch. I have found scattered pairs along the Pinkham Notch road, and in the Wildcat Valley have traced them up to the divide in Carter Notch at an altitude of 
slightly over 3,00o feet. They avoid the forest, however, and are more frequent in low growth along open spaces.

Dates: May ig to September I3.

¿:9. Geothlypis trichas brachidactyla (Swains.).

NORTHERN YEILOW-THROAT.

A common summer resident of swampy, weed-grown localities in the Transition and sub-Canadian areas, following the valley's up to about 2,000 feet in the IVhite Mountains.

Dates: May 8 to October 7 .

Note: Icteria virens (Linn.). YelLow-BREASTED CHAT.

According to T. M. Brewer (' $7 S$, p. 303) a nest and four eggs of this bird were taken in the summer of $\mathrm{IS}_{77}$ at North Conway, by his "young friend, C. A. Hawes." It seems unlikely, however, that so southern a bird should breed ihus far to the northward, and until a well authenticated specimen can be shown from the state it should not be given a place among the birds of New Hampshire. Careful search on our cxtreme southeastern borders might nevertheless establish its occasional presence there.

\section{Wilsonia pusilla (Wils.). WILSON's WARBLER.}

An uncommon spring and fall migrant and a rare summer resident in the upper Canadian faunal area. Mr. F. B. Spaulding ('94) has recorded finding a nest with four eggs on June 5 , I 894, near Lancaster. The female bird, he states, was captured on the nest. Dr. Walter Faxon informs me, also, that he observed a single bird below Warren Village on June 4, I895, perhaps a late migrant. I have never found the bird among the White Mountains in the breeding season, and although Mr. C. J. Maynard ('72) quotes Mr. William Brewster as authority for its presence during summer at Gorlian, it appears that the birds in question were probably early fall migrants. At Intervale, the first fall migrants appear in the valley about the middle of August, my earliest date being on the i 5 th of that month. Single birds are usually found, or more rarely two may be observed accompanying a flock of other Warblers and Chickadees in a clanp, busliy locality. Dr. Walter Faxon has observed the bird at Warren so late as October $3 \mathrm{~d}$.

Dates: May 13 to October 3. 
2:31. Wilsonia canadensis (Lin11.).

CANADIAN WARBI, H.R.

A common spring and fall migrant, and less commons summer resident within the Canadian fannal area. It is common in stnmmer in the White Mountain region along the forest brooks grown up with spruce, balsan and a tangle of hobble bush, where the dampness keeps the gronnd deeply carpeted with moss; and in similar situations it occurs locally throughout the state, though in central and southeastern New Hampshire it is far from common. Mr. G. H. Thayer finds it in considerable numbers in the deep, well-watered woods about Mt. Monadnock. The greatest altitude at which I have observed breeding birds is 3,360 feet in the Carter Notch, where on June 21,1900 , a bird was heard singing by the lakes.

Dates: May 13 to September I3.

2:32. Setophaga ruticilla (Linn.). AMFRICAN REDSTART.

A common migrant and summer resident of the Trausition and sub-Canadian woods throughout the state. On the White Mountains it is fairly common in the deciduous and mixed woods up to about 3,000 feet, and appears to be commoner in such localities than about the village shade trees and the orchards. The Redstart is the "Paul Pry" of the woods, and in the northern forests I have usually found it to be about the first bird on the scene whenever a passing Blue Jay or other intruder appears.

Dates: May 4 to September 2 I.

2:3:3. Anthus pensilvanicus (Lath.). Amfrican PrprT.

A migrant, uncommon in spring but more numerous in fall. Inland, the bird appears to be rare in spring, though on the coast it is of regular occurrence. Messrs. Goodhue and Dearborn have noted it in spring in Belknap and Merrimack Connties. In the White Monntain valleys. I have ustrally observed it in small flocks after the 15 th of September.

Dates: April to May Io; September 5 to November. 
234. Galeoscoptes carolinensis (Lin11.). CATBIRD.

A rather common summer resident of the Transition areas, following the valleys up to the outskirts of the White Mountains and reaching the lower country to the north of that range, as at Jefferson where it occurs sparingly. At Intervale, a few pairs are annually to be found in the river bottom, or rarely on the sides of the valley up to 500 or 600 feet. I know of one pair, presumably the same birds, which has nested for at least three or four consecutive years in the same isolated clinip of bushes by a brook on the edge of our meadows. These birds, which I used often to watch, were frequently found to be active until it was quite dusk and after most of the other diurnal species had quieted down for the night. Mr. Bradford Torrey has observed this bird in Franconia up to Oct. 5, and a Mr. D. L. Oliver $(: 02)$ records one observed at Concord so late as the $3 \mathrm{~d}$ of December, $190 \mathrm{r}$.

Dates: May 6 to October 5 (December 3 ).

234. Toxostoma 1ufum (Lin11.). Brown THRASHER.

A summer resident within the Transition areas. In southeastern New Hampshire it is not uncommon but elsewhere it is found in less numbers following the river bottoms up into the White Mountain valleys. At Intervale, I have usually found two or three pairs each year in the fringe of vines and bushes on the banks of the Saco River. In a considerable stretch of rolling sandy country grown up to bear oak and grey birches in the vicinity of West Ossipee and Tamworth, these birds are fairly common, hannting the thickets with the Towhees. To the north of the White Mountains, I am not certainly aware of the presence of this bird, nor does. Mr. F. B. Spaulding include it in a manuscript list of birds seen by hin at Lancaster. Dr. W. Faxon has noted it at Warren.

Dates: April 16 to September.

235. Thryothorus ludovicianus (Latli.). CAROI+INA WREN.

An accidental visitant from the sonth, having been once recorded at Rye Beach, where Mr. H. M. Spehman ('8Ia) on 
August 7, I8So, shot one bird and saw at the time a second, which, however, he failed to secure. These birds were "in a thick piece of woods" in which Mr. Spelman was collecting. The sex of the specimen killed, is not stated. Mr. R. Hoffmann also writes me that a single one was observed singing at Alstcad, on July 6, 1903, for part of that day onily.

236. Thryomanes bewickii (Aud.). BewICK'S WREN.

An accidental visitant from the south. The only record is of a bird shot at Alton, on April 25, I89o, by Mr. Ned Dearborn ('98, p. 32). Mr. William Brewster has examined this specimen and confirms the identification. Mr. Dearborn remarks that "this wren is not often found in New Hampshire," and it may be added that this record is not only the sole one for New Hampshire, but for New England as well.

\section{3\%. Troglodytes aedon Vieill. HOUSE WREN.}

An uncommon summer resident of the Transition valleys in the southern and central parts of the state. In the Connecticut valley I have found it rather common about Walpole, and it occurs at least as far up as Lancaster where Mr. F. B. Spaulding has observed it. In central New Hampshire it follows the conrse of civilization along the valley bottons, but appears to be rare north of Lake Winnepesaukee. At Intervale a pair has summered for several consecutive seasons about an apple orchard near our grounds, and $I$ have also found it in summer at North Conway, the nearest village to the south in the Saco valley. Mr. C. J. Maynard ('72) has even recorded the bird from Lake Umbagog, where he states it is rare. Mr. F. H. Allen has also once seen the bird in early summer at Jefferson on the north side of the White Mountains.

Dates: May 18 to September 24.

2:38. Olbiorchilus hiemalis (Vieill.). WINTER WREN.

A rather common spring and fall migrant, and, thronghont the Canadian area, a summer resident of very general distribution along the cold brooks and swamps in the deep forest; it is also a very rare winter resident in the southeastern parl of the state. Thus Dr. W. H. Fox writes me that at Hollis he ob- 
served a male on February 19, I875, and again on March 16 of the same year. The weather was cold at the time, thermometer 4 degrees below zero. Mr. W. E. Cram ('99) also records one seen at Hampton Falls in late December, I897, and a Mr. J. H. Johnson ('92) records one seen in "central New Hampshire" on Nov. 25, Dec. 5 and Dec. 12, I892. Throughout the northern part of the state, the bird is common as a summer resident in suitable localities. In the White Monntains it is common along all the little forest brooks up to their very sources. Thus in Tuckerman's Ravine, and at the head of the Great Gulf on Mt. Washington, a few are to be found anong the scrub, where the mountain streamlets keep the mossy gronud saturated, so high up as 4,500 feet. To the south of the White Mountains it breeds here and there at the lower elevations as where, on the northern exposures of hills, a growth of balsam and spruce forms a cold swamp or borders a dashing mountain stream. In such localities, the bird is not uncommon abont Newfound Lake. Mr. C. F. Goodhue ('77a, p. 33) also notes a male in full plumage and song taken on South Kearsage, June 22, 1875. Mr. Ralph Hoffmann has once observed the bird at Marlow in the summer of 1900 , and Mr. G. H. Thayer writes me that it breeds sparingly in the woods of Mt. Monadnock. In the Carter Mountains, about the lakelets in the Notch, it is not unusual to hear half a dozen birds singing from the dense forest round about, or from the wooded cliffs above. Long before daylight, their songs break the morning stillness, as one bird after another takes up the melody. Here they stay on their breeding grounds until at least the middle of September at which date I have heard occasional birds still singing in the early morning about the Carter lakes $(3,360$ feet $)$.

Dates: April 5 to November 15 (Winter).

\section{Cistothorus stellaris (Licht.). SHORT-BILLIDD} MARSi WREN.

A rare and local summer resident in the southeastern part of the state. Mr. H. M. Spelman ('82) was the first to record the bird's breeding in the state. He found at Rye Beach on the $24^{\text {th }}$ of August, I882, some half a dozen birds inhabiting a 
small fresli-water meadow about a mile from the sea. He also states that Mr. William Brewster fonnd the bird in I872, about five miles farther inland from this locality. Mr. W: E. Cram writes me that at Hampton Falls a few miles south of Rye Beach, the bird breeds in a swamp in the western part of the town. Mr. F. W. Batchelder (:00, p. I36) records further that at Manchester, in r899, a nest was found in the Cohas Brook. meadows. Still more recently in 1902, Mr. G. H. Thayer has discovered a pair of these wrens in a certain grassy swamp at an elevation of slightly over a thousand feet at Dublin. Throughont June the male was often seen singing, and on August 5th an old nest was found. Elsewhere in the state, I have no knowledge of its presence, save at Intervale where I shot an immature female specimen on September 15 , r898, as it was hopping about among some corn growing on the Saco neadows. The bird must have been a migrant, but its presence so far north as this valley in the mountains must be exceptional. It is now in the Howe-Shattuck collection, No. 936.

Dates : May 23 to October 4.

\section{Certhia familiaris anericana (Bonap.). Brown} CREEPER.

A permanent resident, confined during the breeding season to the thick coniferous woods of the Canadian faunal area, where, however, it is rarely common, though of general distribution. As a winter resident, it is fairly common throughout the lower parts of the state. Among the White Mountains it occurs in summer at least as high as 4, roo feet where I have seen it anong the small timber in Tuckerman's Ravine. Mr. William Brewster (' $79 \mathrm{~b}$ ) has given a good account of the nesting habits of this species about Lake Umbagog where it breeds not uncommonly in the deep woods, eggs being found from May 3 I to June 23. At Intervale, I have usually found a pair or two among the big pines at about 525 feet. A few also regularly breed in the hill country in the western part of the state. Mr. G. H. Thayer writes me that it breeds sparingly on Mt. Monadnock above I,500 feet. I liave fonnd a few birds in winter so high as 3,000 feet in the Carter Mountains. 
241. Sitta carolinensis Lath. WHITE-BREASTFPD NUTHATCH.

A permanent resident, of common occurrence throughout the year in the Transition portions of the state and less common in the sub-Canadian areas. Mr. C. J. Maynard found it a connmon resident at Errol in I870. In the White Mountains, I have usually found it in the wooded valley bottoms, and less often in the beech growth on the mountain sides up to 1,500 or $2, \infty 00$ feet.

24\%. Sitta canadensis Linn. RED-BRFASTED NUTHATCH.

A common permanent resident, confined during the breeding season to the Canadian fauna. In summer, this species entirely replaces $S$. carolinensis above 3,00o feet on the White Mountains, and is commonest from that level up to 4,500 feet in the thick forest of living and dead firs and spruces. In small numbers, it regularly breeds along the height of land in the western part of the state, and sporadically over the more southern districts. Mr. C. F. Goodhue ('77a, p. 33) has recorded it as nesting on South Kearsarge; Mr. Ned Dearborn ('98, p. 33) also notes it as nesting in central New Hampshire, and Mr. G. H. Thayer finds it regularly about Mt. Monadnock. In late summer and fall the birds wander about with the flocks of other small birds and even occur now and then above the upper limit of tree growth on the Presidential range. Thus Dr. A. P. Chadbourne ('87) records one seen on Sept. 2, r884, running over the bare rocks on the summit of Mt. Clay, and Mr. Bradford Torrey has seen them on one or two occasions at this season scrambling about on the roof of the Summit House on Mt. Washington. Most of the birds move down into the valleys and the southern parts of the state during winter. In some seasons they are extremely abundant, and again few are seen. Dr. W. H. Fox writes me that at Hollis, in 1886 , they were very abundant during late June and all of July. In i 895, they swarmed throughont the White Mountain forests in fall. They were also fairly abundant in 1899 over parts of the state, though in the 
following summer and fall, they seemed strangely absent from much of the northern woods.

\section{Parus atricapillus Linn. CHICKadEE.}

A common permanent resident througlout the Transition and sub-Canadian areas. On the White Monntains, it is rarely observed much ligher than the 3,000 foot limit during the breeding season, giving place about that level, to the Hudsonian Chickadee. After the nesting period, small family parties, consisting of the parent birds and their several full grown young, are frequent in all the woodlands, and rarely they wander up into the small timber growth to perhaps 4,000 feet, on the mountains. The immature birds are easily to be distinguished by their notes which soniewhat resemble those of the Hudsonian Chickadee. In late summer, many warblers, nuthatches, kinglets, and vireos join these small flocks of Chickadees, and form large bands which rove through the forests in an apparently aimless way, searching for food. After the warblers and other birds of passage have left, these little flocks still hunt through the winter woods going at least as high as 3,400 feet, at which level in late December I have seen them in Carter's Notch. In April, these flocks break up, and the birds pair off to nest. Often at this season is heard their plaintive love note, and a whistled imitation, though usually disregarded at other seasons, is now eagerly answered by any single bird within hearing, and seldom have I failed on such occasions to bring the bird to the trees over my head. Sometimes, by continuing to initate the note as I walked along, I have had a lone Chickadee follow me for over a mile, answering note for note. I have sometimes noticed also that birds which have evidently paired already, will pay no attention to the call even after many repetitions.

244. Parus hudsonicus Forst. Hudsonian ChickadeE.

A rather common permanent resident of the upper-Canadian area on the higher White Mountains and in the northern part of the state. During the breeding season, it is confined, on the White Mountains, to the damp fir and spruce belt from 3,000 
feet to the upper limit of small tree growth at 4,800 to 5,000 feet, though not at this time often seen above the timber, which extends to some 4,500 feet on the southern exposures. South of the great range, I have observed it in summer on Mit. Carrigain and on Mt. Hancock, and it is to be looked for on the higher peaks of the Sandwich range. In late summer, small flocks are frequently met with trooping through the evergreen forest and usually accompanied by a few Black-poll and Myrtle Warblers and a pair or two of Red-breasted N uthatches or Golden-crowned Kinglets. These flocks in their wanderings reach the extreme upper limit of scrub growth on the mountains, and I have observed them on such occasions at Madison Hut, on the west side of Mt. Adams, and at the summit of Carter Dome $(4,860$ $\mathrm{ft}$. ). They move downward into the valleys as late fall and winter approach. Thus Mr. C. J. Maynard ('72) found them quite common in late October, $x 869$, in the heavily wooded mountain valleys at Errol. Frank Bolles ('93b) noted them repeatedly about Chocorua in December, single birds being usually seen, though once he mentions a flock of four on December 22d; he also mentions one at Whitten Pond on November 7 th. Mr. G. C. Shattuck has twice observed the bird near Albany Intervale during the last of December, I900, and again on February $\mathrm{z} 7 \mathrm{th}$, of the following year. Doubtless however, a large part of the birds remain throughout the winter at high altitudes, and I have observed one or two at about 3,000 feet on the Carter Notch trail during the last of December, r 900 , after severe weather. Rarely, straggling birds reach the country to the south of the White Mountains in fall or winter; thus Mr. C. F. Goodhue ('85) records one shot at Webster in November, I875, and two seen there in November, 1878 , and I am told of two specimens taken near Mt. Monadnock in winter, by Mr. H. I. Piper. Mr. A. A. Eaton, of Seabrook, writes me of one taken February 15, I890, in Salisbury, Mass., but a few yards from the state line.

245. Regulus satrapa Licht. GOLDFN-Crownid KingI.ET.

A permanent resident, confined during the breeding season to 
the Canadian area. It is common as a spring and fall migrant throughont the state and less common as a winter resident at least as far north as the coniferous forests of the White Mountains. In sonthern and central New Hampshire it is found in summer almost wholly in spruce woods, and sometimes a pair will spend the entire season in a grove of these trees of very small extent. On the White Mountains, the birds occur in the warmer months up to the limit of tree growth at 4,800 feet as I have noterl on Mt. Madison. In the Carter Monntains on Sept. 5, I 899, I observed considerable numbers of Kinglets in the thick balsam forest on Carter Dome $(4,860$ feet). In flocks of from four or six birds to in one case forty, they seemed to be moring down the mountain, passing us by as we ascended. Mr. G. H. Thayer finds this a common breeding bird in the spruce woods of Mt. Monadnock and at other places in the sontliwestern part of the state it occurs locally in summer.

246. Regulus calendula (Limin.). RUby-crowneid KINGLE'T.

A common spring and fall migrant. It is not positively known to summer in the state, and Mr. F. H. Allen is now inclined to the belief that the birds noted by him ('89) as seen in early August, 1885 , at Moultonboro, were not of this species. The first fall migrants appear in the White Mountain valleys in early September, and I have seen them at Intervale by the 9 th of that month.

Dates: April if to May II; September 9 to October 10.

Note: Polioptila carulea (Iinn.). Blue-gray GNatcatcher.

This species is recorded in Vol. 2 of the Proceedings of the Manchester Institute of Arts and Sciences (pp. 77, 83) as having been seen at Manchester on May io, 1900, by two ladies. Although the Blue-gray Gnatcatcher is known from southern Maine, and might thus accidentally occur in New Hampsliire, its presence in the state does not seem sufficient1y authenticated to warrant its inclusion in this list.

24\%. Iylocichla mustelina (Gmel.). Wood Trrush.

A rare summer resident, of occasional occurrence in the 'Transition valley bottoms so far north at least as the White Mountains. Apparently this bird has slightly extended its range 
within the last five or six years, but so far as I can ascertain in New Hampshire, this appears not to be noticeably at the expense of any other species. On the coast, MIr. W. E. Cram has noted it in summer at Hampton Falls. In the Merrimack valley, Mr. F. W. Batchelder (:oo) gives it as a summer resident abont Manchester, and at Concord I am informed of its presence by Mr. W. W. Flint. Mrs. E. E. Webster also writes of having observed it at Franklin Falls on May 2I, I900, and Mr. Ned Dearborn ('98, p. 34) records it from Franklin on local authority. In the southwestern part of the state, a few reach the lower Connecticut valley and Mr. Ralph Hoffmann has observed it at Alstead in 1899 and r 900 . Mr. G. H. Thayer assures me that up to about 1895 he had never seen the bird about Dublin. but that it now appears annually in small numbers about Dublin Lake, and occurs also at Keene, Hancock and Marlboro, preferring the sugar maple groves. Evidently these birds have followed up the side valley from the Connecticut. Farther to the 11orthward, I have observed a single bird at Wonalancet on the Birch Intervales, July I4, I899. Mr. F. H. Allen has also observed one on June 7, 1900, at Chocorua. In the Saco valley at Intervale, I had never seen the Wood Thrush until July 5 , I 899, when I found a bird singing anong some nndergrowtl in a large grove of sugar maples by the river. The bird was observed singing in the same spot the following year on June 18 th. Dr. Walter Faxon also tells me that he observed two Wood Thrushes singing near Mt. Moosilatuke on June 20, I894, and two others in song on the Breezy Point road, North Woodstock, on June I, I895. In the latter instance the birds were at so considerable an elevation as about 2,00o feet. More recently, Mr. Bradford Torrey (:oo) has for the first time found it in the Franconia woods, two birds in full song being noted in late May and early June, 1899. In one case, at least, the bird was in a large sugar maple grove. Mr. Horace W. Wright (:02) has recorded the bird for the first time to the north of the White Mountains in the Jefferson valley in 1902 .

Dit (es: May 15 to September.

248. Hylocichla fuscescens (Steph.). Wilson's Thrusir. 
A common summer resident throughout the Transition valley bottons, frequenting the courses of shaderl streams. In the Connecticut valley of sotthwestern New Hampshire, this is a very common bird, nesting along the river banks among the rank growth of Equisetum. It is common in the White Monntain valley's on both sides of the main range, and follows up the side branches of the rivers to about $I, j$ oo feet, thus reaching well into the lower edge of the sub-Canadian area. At Intervale, these thrushes occur in bushy places all over the valley floor of the Saco, and numbers follow back the little side streams well up onto the mountain sides. so that it is possible in some places to hear the Hermit, the Olive-backed and the Wilson's 'Thrushes all singing at once. I observed a single bird singing in the wet woods at I,700 feet on June I6, I902, at Jackson.

Dates: Nay io to September 8.

\section{Hylocichla aliciae (Baird). GRAY-CHEEKED THRUSH.}

A rare migrant. Mr. G. H. 'Thayer writes me of a male shot at Dublin on Oct. 2, 1899, by Mr. I. A. Fuertes, who identified it as of this species.

250. Hylocichla aliciae bicknelli Ridgw. BICKNELL'S THRUSH.

A common summer resident of the upper Canadian zone on the ligher mountains of central New Hampshire. Mr. Bradford Torrey, in 1882 , was the first to call the attention of ornithologists to the presence of this bird in summer on the White Mountains, and Mr. William Brewster ('83a) took the first New England specimens on Mount Washington in the same year. It is plentiful in the damp, stunted fir growth above 3,000 feet on all the larger mountains, and on the Presidential range occurs as high as the upper limit of stunted tree growth. South of the main ranges, it doubtless breeds in suall numbers on the Sandwich range, where $\mathrm{Mr} . \mathrm{F} . \mathrm{H}$. Allen has found birds in late June on Tripyramid $(4, \mathrm{I} 84$ feet) and Black Mountain (3,900 feet) as well as on Osceola and Tecumseh (both over 4,ooo feet) and has also heard them singing June 7 , 1900, near the top of Mt. Chocorua $(3,508$ feet) the easternmost monntain of this range. 
Frank Bolles appears not to have observed the bird here in summer, however, nor did I find it during a day and night spent near the summit of Chocorua in late August. On Moat Mountain, an adjacent ridge, I have nevertheless observed a single bird on July $\mathrm{r} 7, \mathrm{r} 898$, in a damp thicket of spruces at hardly more than 2,700 feet, and others in early September, 1902, in the stunted growth at 3,000 feet. Dr. Walter Faxon tells me that at Mount Moosilanke. he has fonnd these birds arriving on their breeding grounds between the $25^{\text {th }}$ and 3 otl of May, and that a nest was observed there by Mr. William Brewster and himself, which on June $22 \mathrm{~d}$, contained the full complement of three fresh eggs. On the Presidential and Carter Monntains, where I have been familiar with the bird, an occasional outlying pair may be found as low as perhaps 2,600 feet in some cold brook bed, but they are commonest from about 3:300 feet up to the limit of small tree growth, at about 4,800 feet. They are silent much of the day, and are effectually concealed in the almost impenetrable thickets of scrub growth. In the early dawn and after sunset, they are active, however, and from all sides may be heard their clear, wild call-note, or less often the far-away, high-pitched notes of their song, strangely impressive in the mountain solitudes. The song period is practically over by the middle of July, though I have heard an occasional song in the early morning as late as September 15 th, in Carter Notch, where at this date the birds are still on their breeding grounds. They are then only to be heard, however, in the very early morning or just at dusk. On September 15, i90o, while camping in the notch by the lakes $(3,360$ feet $)$, I arose early and by 4 o'clock A. M., the first dim light of dawn was faintly to be discerned over the eastern wall of the notch. At just 4:37 A. M., as the pale light of the half moon was giving place to the first rays of day, a single Bicknell's Thrush was heard far overhead, on the big ledge which faces the east and forms the otler side of the notcli. Soon others were heard above, but as the stin, some while later, struck the upper ledges, only the birds still in the shadow below continted to call. It was most interesting to note the manner in which the birds stccessively becaure 
quiet as the rising sun lit up more and more of the far side of the notch, until finally by $8: 30$, its rays shone full into the cleft of the mountain, and only a single bird was still calling from a spot yet shaded by a protruding shoulder.

Dates: May 25 through September.

\section{Hylocichla ustulata swainsonii (Cab.). Or.tVE-} BACKED T'HRUSH.

A rather common spring and fall migrant and snmmer resident. During the breeding season it is commonest in the damp, cool undergrowth of evergreen and young second growth along brooks, or wood-swamps of the sub-Canadian regions, where it is found with the Winter Wren and Canada Warbler. It is essentially a bird of the cool, moist thickets, and is found in the White Mountains up to 4,500 feet. Above 3,000 feet or thereabouts, on entering the upper Canadian zone, its numbers become slightly less, and the few birds occurring above 4,000 feet are confined rather closely to the stream beds. This distribution, which has also been noted by Dr. A. P. Chadbourne ('87), I was interested to observe among other places in the mountains, while on a trip with Mr. V. D. Lowe in June, I900, through the Great Gulf of Mt. Washington. We camped at Spaulding's Lake, a tiny sheet of water at the foot of the head wall and at an elevation of about 4,500 feet. All about was a thick growth of scrubby balsams and large alder bushes. Bicknell's Thrushes inhabited this growth on all sides well up onto the walls of the gulf, and at all hours of the day were heard calling. There was noted here but a single Olive-backed Thrush, this being a fine male, who sang persistently from 3 o'clock in the morning until our departure, a few hours later, secured from view the while by the thick balsam scrub at the foot of the lake. A little farther down the brook, a second bird was heard singing on that morning of June 2 Ist, but it was evident that these were the extreme outposts which at these upper levels had invaded the Bicknell's 'Thrushes' territory. On the lower mountain tops, Olive-backed Thrushes are not uncommon in dry spruce thickets with the Hermits. Soutl of the White 
Mountains, these thrushes are rare and local in summer, but occur here and there in cool swamps or along mountain brooks, as I have noted rarely at Bridgewater in 1900 . Mr. E. A. Preble writes me of a nest found on June 20, a number of years ago, on the Ossipee Hills at Ossipee. Mr. C. F. Goodhue ('77a, p. 33) has also recorded it as having bred once near Webster. Farther south, Mr. G. H. Thayer writes me that it breeds regularly in small numbers among the thick spruces near the summit of Mit. Monadnock above 2,500 feet, and sporadically in the lower country to the northward; he has also found it in some numbers at Nubanusit Lake, Hillsboro' County.

Dates : May 16 to October.

\section{5:. Hylocichla guttata pallasii (Cab.). HERMIT THRUSH.}

A rather common summer resident of the sub-Canadian woods to which it is almost entirely confined during the breeding season. A few summer in the extreme southwestern portions of the state, and in the lower Connecticut Valley it is not nncommon on the ridges and among the dry woods of mixed growth. In central New Hampshire in the Winnepesaukee region it is certainly the commonest thrush, frequenting the dry hillside woods. Among the White Mountains, Hermit Thrushes are fairly common at the lower levels, inhabiting the white pine forests, or the more open scattered growth of red and pitch pine in the valleys, where a sandy soil supports an undergrowth of bear oak and braken. In the beech woods about the foot of the mountains up to 2,000 feet, these thrushes are less common or absent, but on the lower peaks, as on Bartlett and Kearsarge, they appear again in small numbers in the dry clumps of dense spruces which grow here and there among the barren ledges up to 3,000 feet or so. Above this level on the larger mountains, the bird is practically absent. Dr. A. P. Chadbourue ('87) has, however, recorded a single specimen scen in summer as high as 3,300 feet on Mt. Washington. Hermit Thrushes, even in late summer, are active until the twiliglit becomes almost too deep to permit more than a dim view as a bird is startled here and 
there from some wood road, and flies to the bushes with its characteristic "chuck." In the Acworth Public L,ibrary collection there is a specinen taken at that town so late as November 24 , I883. I have observed the males already in song on their arrival at their breeding grounds at Chocorua, April 20, I900; the song period is practically orer by July 20 .

Dates: April ig to November 24.

253. Merula migratoria (Linn.). American Robin.

An abundant spring and fall migrant and common summer resident of the Transition areas; also a ratler irregular winter resident. During the summer, these birds are genterally found near habitations, and nest in the shade trees about dwellings or in the orchards. Occasionally, however, as in the White Mountains, birds will nest in the pine trees on the edge of the woods, and Mr. G. H. Thayer also writes me that they sometimes breed in the wild spruce woods of Mt. Monadnock. On June I4, I902, Mr. A. H. Clark and I noted a single bird in the dense woods on Imp Mountain of the Carter Range, at about 3,500 feet, possibly only a stray specimen. In August after the young are on the wing, large flocks gather to feed on the wild cherries ripening in the valleys. Others are to be found scattered in small flocks through the woods at the lower altitudes, and I have on one or two occasions found small flocks about the lakelets in Carter's Notch in mid-September, the birds having apparently paused in their southward flight to feed. Again, I noted a single bird on the nearly barren summit of MIt. Hight (4.770 feet) of the Carter range, and on Aug. 27, I90I, three birds flew past me and alighted among the scrubby firs in the col between Mt. Jefferson and Mt. Adams of the Presidential range. Dr. A. P. Chadbourne ('87) also notes a wandering pair seen on July I2, I886, on the Crawford Bridle path at an altitude of 5 ,oso feet. A few robins appear to winter with more or less regularity in the southeastern part of the state. Mr. W. E. Cram reports them as found at Hampton Falls the year round; and Mr. F. W. Batchelder $\left(: \infty\right.$, p. $\left.{ }^{2} 38\right)$ states that a few winter about Manchester, while a Mr. J. H. Johnson ('92) records them in January, 1892, in "central New Hampshire." There are apparently but few oth- 
er wintering records. Mr. F. B. Spaulding ('86) reports robins as numerous about Lancaster during the winter of ' $85^{-'}$ ' 6 , "something very unusual." Mr. V. D. Lowe also tells me that occasionally a few winter about Randolph, to the north of the White Mountains in the valley of the Androscoggin.

Dates : (February 28) March 3 to December 25; Winter.

\section{Sialia sialis (Linn.). BluebIRD.}

A common summer resident of the Transition regions. It is generally found in open land near farms, or among the orchard trees, and the birds are already on their breeding grounds before the snow has disappeared. The great destruction of Bluebirds by a blizzard which swept the country as they were journeying northward in the spring of 1895. is well known, and in New Hampshire as elsewhere a great scarcity of Bluebirds was recorded for that spring. They seem quickly to have recovered from the blow, however, and in 1897 , I almost daily observed from 4 to 20 or more birds in the Saco valley during September, and they have since been present in about their former numbers. Single flocks will often, in their leisurely fall migration, stop for three or four days at a time in the same locality, evidently finding food in plenty, and thus being in no haste to pass on. Mr. C. J. Maynard (' 72 ) records their breeding at Lake Umbagog.

Dates: March 2 to October 9. 
IN'TRODUCED SPECIES.

1. Tympanuchus americanus (Reich.). Prairie HEN.

According to Mr. Ned Dearborn ('98) a number were liberated in Blue Mountain Park, Croydon, some years ago, and soon disappeared. Mr. Dearborn believes that this will sufficiently account for the fact that one was shot in Sanbornton in March, I893, and that others were reported from Boscawen.

2. Phasianus colchicus Linn. ENGLisir PHEASANT.

Belknap (I792) records that "the late Governor Wentworth brought several pairs of pheasants from England, and let them fly in his woods, at Wolfeborongh; but they have not since been seen."

3. Passer dlomesticus (Linn.). House Sparrow.

Abundant as a resident abont the large villages and cities. Among the country towns of central and northern New Hampshire, it seems not to be increasing, and indeed barely holds its own in many places among the White Mountain valleys. Thus at Intervale, I have not observed any increase in numbers during several years, though a single pair or two is annually found nesting about the village. 
POSTSCRIPT.

While these pages are going through the press, there has appeared an important contribution to the ornithological literature of the state, in the shape of a paper by Mr. Ned Dearborn on the "Birds of Durham and Vicinity" (:03). 'This list is important, especially because it covers the southeastern part of New Hampshire and is the result of long observation in a region on which there has hitherto been little published. Mr. Dearborn's researches now make it possible to add to the avifauna of New Hampshire no less than twenty-nine species, which had not been included in the foregoing list, mainly because of a lack of definite records. These additions are as follows :-

1. Alea torda Linn. RAZOR-BILLED AUK.

Stated to occur " in more or less abundance on the coast every year from November to March."

¿. Larus delawarensis Ord. RING-BILLAD Gudx.

Fonnd by Mr. Dearborn to be a spring and fall migrant along the coast.

3. Sternal caspia Pallas. CAspian TERN.

Two were shot at Hampton in the fall of 1899 . Both were in inmature plunnage, and the skin of one is now in the collection of Mr. S. A. Shaw, of Hampton.

4. Sterna antillarum (Less.). LraST TERN.

Mr. Dearborn includes this species on the testimony of Mr. S. A. Shaw, who finds it uncommon at Hanpton, and has a single specimen in his collection. 
5. Puflinus cravis (O'Reilly). Grisater SHEARIVATER.

A specimen, taken near Portsmouth, is stated to be in the collection of Mr. W. M. C. Philbrick, of Kittery, Me.

6. Chaulelasmus streperus (Linn.). Gadwali.

A pair of spring birds taken on Little Bay, near Portsmouth, is said by Mr. Dearborn to be in the collection of Mr. George Wentworth of Dover, and Mr. S. A. Shaw is anthority for the statement that a few have been killed at Hampton during the last twenty-five years.

\%. Dafila acuta (Linin.). Pintarl.

"Rather scarce spring and fall migrants."

S. Aythya americana (Eyt.). REDHFAD.

Mr. Dearborn states that he has found several autumnal specimens in local collections.

9. Clangula islandica (Gmel.). BARrow's GoldenEYE.

Mr. Dearborn has examined a specimen of this species in the collection of Mr. George Wentworth of Dover, which was shot "some years since on Little Bay."

10. Somateria spectabilis (Linn.). KING EIDER.

A female taken at Hampton, and in the collection of Mr. S. A. Shaw, is identified by Mr. Dearborn as of this species.

11. Ardea egretta Gmel. AmErican EGRET.

A specimen is recorded as shot in the summer of 1897 on the river about a mile above Newmarket village.

12. Rallus crepitans Gmel. Clapper RaIL.

A specimen taken at Portsmouth some years since, after a southwesterly gale, is said to be in the collection of the college at Durham.

13. Porzana noveboracensis (Gmel.). YELLOW RAIL. A specimen taken at Hampton is in the collection of Mr. S. A. Shaw. 
14. Ionornis martinica (Linn.). PURPLE Galdinule.

A specimen was killed at Rye some years since, and a second at Willand's Pond, Dover.

15. Gallinula galeata (Licht.). Florida Galitinule. One was killed at Rollinsford some years ago.

16. Himantopus mexicanus (Mull.). BLACK-NECKED STILT.

Mr. Dearborn states that "some years ago a summer visitor at Rye Beach" brought one to Mr. Shaw, at Hampton, to be mounted.

1\%. Tringa canutus Linn. KNOT. fall.'

Of "fairly common occurrence along the coast spring and

18. Tringa maritina Brumn. PUkPle SANDPIPER.

In eight local collections, Mr. Dearborn finds but two specimens of this bird. One was killed in January.

19. Ereunetes occidentalis Lawr. WESTERN SEMIPALMATED SANDPIPER.

Mr. Dearborn refers to this species a long-billed female bird, taken at Hampton, Oct. IO, I899. That the unusual length of bill might fall within the limits of variation of the eastern bird, however, is a possibility which should not be overlooked.

20. Limosa hamastica (Limn.). Hudsonian Godwrt.

"Taken in October at Hampton."

21. Symphemia semipalmata (Gmel.). WirLET.

"It is a rather irregular migrant along the coast, generally seen in antumn, if at all."

2\%. Agialitis meloda (Ord). Piping Plovfr.

"A regular migrant along our coasts."

2:3. Arenaria interpres ( $\mathrm{L}$ inn1.). Turnstonr.

Said by Mr. Dearborn to be a regular coastwise migrant in spring and fall, but comparatively few in numbers. 


\section{Ieterus spurius (Limn.). ORCHARD ORIOLE.}

'This bird is added to the avifatna of the state on the basis of an adult male taken some years ago at Rollinsford, by Mr. George H. Yeaton, of that town, in whose collection the specimen is.

\section{Quiscalus quiscula (Linn.). Purpla Gracklat.}

Out of nine grackles shot from a flock at 'Tilton on Sept. I3, 1902, two specimens are stated by Mr. Dearborn to be unquestionably of this form. The skin of one is now No. 13,446 of the Field Columbian Museum at Chicago.

26. Acanthis hornemannii exilipes (Cones). HoAry REDPOLL.

Mr. Dearborn has identified as of this race, a specimen in the collection of Mr.S. A. Shaw, of Hampton, where it was presumably taken.

\section{2\%. Calcarius lapponicus (Linn.) LAPLAND LONG-} SPUR.

This species, which should occur as a fairly regular late fall migrant on the coast, is now definitely added to the list on the strength of Mr. Dearborn's record of three seen at Hampton Beach on Nov. 30, 1899 .

28. Ammodramus princeps (Mayn.). IPswich SparROW.

This bird also is to be stricken from the hypothetical list, and is found by Mr. Dearborn to be a regular spring and fall migrant on the sand hills of the coast in March and April, and from the latter part of October to early December.

29. Mimus polyglottos ( Lim.). Mockingbird.

According to Mr. Dearborn, an immature bird, apparently a young of the year, was shot at Hampton, Aug. 24, 1900, and is now in the possession of Mr. S. A. Shaw. The possibility of this having been an escaped cage bird is, of course, not altogether excluded.

In addition to these birds which are now added to the New 
Hampshire list, the following important records in Mr. Dearborn's paper may be mentioned:-

Larus glaucus Brunn. Graucous Guli.

One taken at Hampton in May, some years since.

Spatula clypeata (Lim.). SHOVELER.

"Mr. Shaw has a male taken in autumn some years ago, at Hampton."

Aythya collaris (Donov.). RING-NECKED DUCK.

A fine adult male was taken in the fall on Little Bay.

Histrionicus histrionicus (Linn.). HARLEQUIN DUCK.

"Three or more" are said to be in the collection of Mr. S. A. Shaw, of Hampton.

Olor columbianus (Ord). Whistling Swan.

"Some years ago one was wounded and captured alive on Great Bay" and "another was killed on Great Bay, December 16, 1902," and is now in the College collection at Durham.

Ardetta exilis (Gmel.). LFAST BITTERN.

One taken at Hampton some years ago.

Micropalama himantopus (Bonap.). STILT SANDPIPER.

A specimen taken at Hampton is in Mr. S. A. Shaw's collection.

Tryngites subruficollis (Vieill.). BUFF-BREASTED SANDPIPFR.

One is in the possession of Mr. Joseph Turner of Portsmouth.

Numenius longirostris Wils, LONG-BILLED CURLEW.

Two specimens are noted in local collections, one each at Portsmouth and Rollinsford.

Agialitis vocifera (Linn.). KILLDHER.

Mr. Dearborn is "assured by Mr. Wentworth of Rollinsford that years ago Killdeers nested regularly on his farm," and another informant states that they formerly bred about the marshes near Portsmouth. 
Nyctala tengmalmi richardsoni (Bonap.). RICHARDSON's OWI.

A specimen killed in Dover and now in the collection of Mr. G. F. Wentworth of that city, is the sixth record for the state. Surnia ulula caparoch (Mull.). Axerican Hawk OwL.

Mr. Dearborn adds two records for the state, a single bird having been taken "recently near Portsmouth" and another near Piscataqua bridge.

Coccyzus americanus (Lin11.). YELLOW-BILI,ED CUCKoo.

Mr. S. A. Shaw "has taken it at Hampton."

Melanerpes erythrocephalus (Linn.). RED-HFADED

WOODPECKER.

Two specimens in immature plumage are said to be in the collection of Mr. S. A. Shaw, of Hampton. An additional record is of one seen at Hebron by Mrs. C. P. Webster (see Howe, Pasquaney Annual, r902, N. S., vol. IV).

Perisoreus camadensis (Linn.). Canada Jay.

According to Mr. Shaw of Hampton, two were killed at Boar's Head, some years ago.

Cocothraustes vespertimus (Coop.). Evening GrosBEAK.

Additional records for the 1890 flight are of two birds secured from a flock of sixteen at Newmarket.

Helminthophila chrysoptera (Lim1.). GOLDEN-WINGED

WARBLER .

A male specimen is recorded as taken at Durham on May 24, I 898, and now in Mr. Dearborn's collection.

Note: It has not been possible to incorporate in the present paper the numerous clianges in nomenclature found necessary in the 'Twelfth Supplement to the American Ornithologists' Union Check-I,ist of North Anerican Birds (Auk, vol. 20, no. 3, July, 1903).

Cambridge, Oct. 26, 1903. 
REFERENCES TO LITERATITRE.

ALLEN, F. H.

'89. Summer birds at Bridgewater and Monltonboro', New Hampshire. Auk, vol. 6, 110. 1, p. 76-79.

ALLEN, J. A.

'69-'70. Notes on some of the rarer birds of Massachusetts. Amer. Naturalist, vol. 3, 110. ro, Dec., I869, p. 505-519; no. Ir, Jan., r870, p. 568-585; 110. I2, Feb., r 870 , p. 63I-648; also sep., p. I-49.

\section{A UDUBON, JOHN J.}

'6o. Birds of America. New York; 6 vols.

BAIRD, S. F., T. M. Brewer, and R. Ridgway.

'74. A history of North American birds. Land birds, vols. I, 2, 3. Boston, 4to.

'84. The water birds of North America. 2 vols. Memoirs mus. comp. zool., vol. I 2.

BATCHELDER, F. W., and E. H. Fogg.

: oo. Preliminary list of birds *** of Manchester, N. H. Proc. Manchester $[N$. H.] institute of arts and sciences, vol. I, p. 123-1 38 .

BATES, F. A.

'9r. Tramping in the White Monntains. Ornithologist and Oologist, vol. r6, 110. 3, p. 33-36.

BEI,KNAP, JEREMY.

1792. The History of New Hampshire. 3 vols. Boston. ( $L_{\text {ist }}$ of birds in vol. 3 , p. 165-174.)

BERRY, MABEL, C.

'96. First occurrence of the Blue Grosbeak in New Hampshire. Auk, vol. 13, no. 4, p. 342 . 
BOLLES, FRANK.

'9o. Barred Owls in Captivity. Auk, vol. 7, no. 2, p. IorI 4 .

'93a. In a wintry wilderness. Atlantic monthly, vol. 7r, Ja11., p. 92-99.

'93b. At the north of the Bearcamp water. Boston; 8 vo.

"BOS'TON IIVENING RECORD."

'99. ["Ducks" or murres at Lake Winnisquam.] Vol. 31, no. 72, Nov. 28, 1899.

"BOSTON SUNDAY HERALD."

'93. [Black-capped Petrel at Pittsfield, N.H.] Oct. I5, I 893.

BRASHER, R. I.

'94. Northern phalaropes off the New Hampshire coast. Auk, rol. I I, 110. 3, p. 250.

BRE WER, T. M.

'78. Notes on certain species of New England birds, with additions to his catalogue of birds of New England. Proc. Boston soc. nat. hist., vol. I9, p. 30I-309.

BRE WS'TER, WILLIAM.

'72. Birds new to Massachusetts fauna. Amer. Naturalist, vol. 6 , 110.5 , p. 306-307.

76 a. On the occurrence of certain birds in the New Eingland states. Bull. Nuttall orn. club, vol. I, no. I, p. I720.

'76b. The Yellow-bellied Sapsucker (Sphyrapicus warius). Bull. Nuttall orn. club, vol. I, no. 3, p. 63-70.

'77a. The Black-and-yellow Warbler (Dendroica maculosa). Bull. Nuttall orn. club, vol. 2, no. I, p. I-7.

'77b. Northern range of the Sharp-tailed Finch (Ammodramus caudacutus). Bull. Nuttall orn. club, vol. 2, no. I, p. 28 .

'78. Descriptions of the first plumage in various species of North American birds. I-IV. Bull. Nuttall orn. club, vol. 3, p. I5-23, 56-64, I I 5-I 23, I 75-182.

'79a. Additional notes on the Whistling Swan (Cy'gnus americanus) in New England. Bull. Nuttall orn. club, vol. $4,110.2$, p. 125.

'79b. Breeding habits of the American Brown Creeper (Certhin familiaris americana.) Bull. Nuttall orn. club, vol. 4 , no. 4 , p. 199-209. 
'8o. Notes on the habits and distribution of the Philadelphia Vireo. Bull. Nuttall orn. club, vol. 5, no. 1, p. I-7.

'81a. Recent occurrence of Baird's Sandpiper (Tringa bairdi) in Maine. Bull. Nuttall orn. club, vol.6. no. $\mathbf{I}$, p. 60-6r.

'8I b. The Short-tailed Tern (Hydrochelidon nigra) in New England. Bull. Nuttall orn. club, vol. 6, no. 2, p. 124-125.

'82. An erroneous record of the Orange-crowned Warbler (Helminthophaga cclata) in New Hampshire. Bull. Nuttall orn. club, vol. 7 , no. I, p. 53.

'83a. Bicknell's Thrush (Turdus alicia bicknelli) in New England. Bull. Nuttall orn. club, vol. 8, no. I, p. I 2-1 7 .

'83b. Notes on the birds observed during a summer cruise in the gulf of St. Lawrence. Proc. Boston soc. nat. hist., vol. 22, p. 364-412.

'85. Hawk Owls in New England. Auk, vol. 2, no. I, p. I08-iog.

'9o. The Evening Grosbeak in New England. Forest and Stream, vol. 34 , no. 3 , p. 44 ; also no. 6, p. I04.

'95. Minot's land and game birds of New England, 2d edition, edited by William Brewster. Boston.

'97. The Lesser Snow lioose in New England. Auk, vol. I4, 110. 2, p. 207.

'98a. Notes on the American 'Three-toed Woodpecker (Picoides amcricanus). Osprey, vol. 2, 110s. 6-7, FebMar., p. 73-76.

' $98 \mathrm{~b}$. Revival of the sexual passion in birds in autumn. Auk, vol. 15 , 110. 2, p. 194.

: $\infty$. Notes on the breeding habits of the American Goldeneyed Duck or Whistler (Clangula clangula americana). Auk, vol. 17, 110. 3, p. 207-216, pl. 6-7.

:or. Bell's Vireo and the Sandlill Crane in New Hampshire. Auk, vol. 18, 110. 3, p. 274.

:02. An undescribed form of the Black Duck (Anas obscura). Auk, vol. 19, no. 2, p. I83-188.

BRO WN, N. C.

'77. Notes on birds new to the fauna of Maine, etc. Bull. Nuttall orn. club, vol. 2, 110. I, p. 27.

'96. The Ipswich Sparrow-a correction. Ank, vol. I3, no. I, p. 84 . 
[CABO'T, J. E.]

'57. Our birds and their ways. Atlantic montlly, vol. I, Dec., p. 209-2 I6.

[CABO'T], DR. [SAMUEL].

'44. [Note on Wild Turkey from N. H.]. Proc. Boston soc. nat. hist., vol. I, p. 8o-8I.

CALL, AUBREY B.

'9o. The Evening Grosbeak in N.H. The Oologist (Albion, N. Y.), vol. 7, Dec., p. $25 \mathrm{I}$.

CHADBOURNE, A. P.

'85. Oporonis agilis and Dendroica palmarum at Shelburne, near Gorham, N. H. Auk, vol. 2, no. I, p. I04.

'87. A list of the summer birds of the Presidential range of the White Mountains, N. H. Auk, vol. 4, no. 2, p. I00- 108.

'89. An unusual flight of $\mathrm{K}$ illdeer Plover (Agialitis vocifera) along the New England coast. A uk, vol. 6, no. 3, p. $255^{-26} 3$.

CHAMBERLAIN, M., Editor.

'9I. A popular handbook of the ornithology of the United States and Canada, based on Nuttall's manual. 2 vols., ill. Boston.

COLBURN, W. W.

'90. Evening Grosbeak in New Hampshire. Forest and Stream, vol. 34, p. 349.

CORY, CHARLES B.

'82. The Turkey Buzzard in New Hampshire. Bull. Nuttall orn. club, vol. 7, no. 3 , p. 184 .

CRAM, W. E.

'99. Winter bird notes from southern New Hampshire. Bird-Lore, vol. I, no. 6, p. 180-184.

DEANE, RU'THVEN.

'76. The Philadelphia Vireo in New England. Bull. Nuttall orn. club, vol. 1 , no. 3 , p. 74 .

'78a. Coturniculus henslozei in New Hampshire. Bull. Nuttall orn. club, vol. 3, 110. I, p. 39.

'78b. The Sooty Tern in New Hampshire. Bull. Nuttall orn. club, vol. 3, no. 4, p. 195. 
'79. Capture of the Loggerhead Shrike in winter in New Hampshire. Bull. Nuttall orn. club, vol. 4, no. 2, p. I 19.

DEARBORN, NED.

'98. A preliminary list of the birds of Belknap and Merrimack counties, New Hampshire. Durham, June, i 898 , p. I- 34 .

: oo. Migration notes from Durham, N. H. Wilson Bulletin, July, I900, no. 32, p. I3-I4.

:03. The birds of Durham and vicinity, etc. Contrib. from zool. lab. of N. H. college of agric. and mech. arts, VI, I 2 I pp., map.

D WIGHT, JONATHAN, JR.

'87. A new race of the Sharp-tailed Sparrow (Ammodramus caudacutus). Auk, vol. 4, no. 3, p. 232-239.

"E. C."

'86. [Bird arrivals at Hanover, N. H.] Forest and Stream, vol. 26, p. 204.

FAXON, WAL'TER.

'89. On the summer birds of Berkshire county, Massachusetts. Auk, vol. 6, no. 2, p. 99-107.

'92. The Prairie Horned Lark (Otocoris alpestris praticola) breeding in New Hampshire and Massachusetts. Auk, vol. 9, no. 2, p. 20 r.

'97. Purple Martins (Progne subis) breeding in electric arclight caps. Auk, vol. I4, no. 4, p. 407.

FAXON, WALTER, and J. A. Allen.

'88. Notes on the summer birds of Holderness, Bethlehem, and Franconia, N. H. Auk, vol. 5, no. 2, p. 149I 55 .

FAXON, WALTER, and Ralph Hoffmann.

:oo. The birds of Berkshire county, Massachusetts. Collections of the Berkshire Historical and Scientific Society, vol. 3, p. 109-166; sep., p. I-60.

FORBUSH, E. H.

'9o. Evening Grosbeaks in Hampden county, Massachusetts. Auk, vol. 7, no. 2, p. 2 Iо. 
FiOX, IV. H.

'76. Three migrations compared. Iiorest and Strean, vol. 6. $110.22, \mathrm{p} .35+$.

77. Capture of the Philadelphia Vireo in New Hanpshire. Bull. Nuttall or lu club, vol. 2, 110. 3, p. 78 .

'83. Richardson's Owl in somtheru New Hanpshire. Bull. Nuttall oru. club, vol. 3, no. I, p. 61.

'S4. Dendroia coronata in southern New Hampshire in sum111er. Auk, rol. I, no. 2, p. I92.

FROS'T, IUI) WIN B.

'85. The Loggerhead Slurke in New IIampshire. Auk, vol. $2,110.4$, p. 379 .

GOOHHLE, C. F. [ "Falco.']

'77a. 'The birds of WVebster and adjoining towns. Forest and Strea11, vol. 8, p. 33-34, 49, 96, i 1 3, 146.

77 b. [Note on Snowy Owl.] Forest and Stream, vol. 9, p. 216.

'85. Winter birds of Webster, N. H. Ornithologist and Oologist, rol. IO, no. I, p. If.

[HARRIMAN, M. C.] M. C. A.

'70. Corvus corax in New Hampshire. Forest and Stream, vol. 12, 110. 6, p. 106.

HATHA IVAY, H. S.

: oo. Odd Notes. Notes on R. I. ornithology, vol. I, no. I, p. +5 .

HA WESS, C. AI,GFiR.

'78. A nesting of the Golden Eagle (.-1quila chry'satus [sic].)

"H. B. E.' The Oologist, rol. 3, no. 1 I, p. 86.

'77. [Bonaparte's Gull at Plymouth, N. H.] Fiorest and Streal1, vol. 8, 110. 2 I, p. $3+5$.

HERRICK, I*. H.

'83. Prairie Warbler in New Hampshire. Science, vol. 2, series $1,110.31,1.309$.

HITCHCOCK, C. H.

'74. The geology of New Hanpshire. 3 rols., fto, Concord. HOFFMANN, RAI,PH.

:03. Nesting of the Coshawk in southern New Haupshire. Auk, vol. 2O, 110. 2, p. 2 II-212. 
HO WE, REGINALD H., JR.

'91. On the Birds' Highway. Boston, Svo.

: OI. A list of the birds of Pasquaney, Bridgewater, N. H. 'The White Birch, "published weekly rluring canp season" by Camp Pasquaney, Briclgewater, vol. 3 , 110. 4. p. 27 ; 110. 5. p. 35 ; 110 6, p. 44 ; no. 7, p. $50-$ $5 \mathrm{I}$.

:02. A review of Prof. George H. Perkins' "A Preliminary List of the Birds found in Vermont." Contributions to North American ornithology, rol. 2 [I], p. 5-23, errata.

HUSE, WILLIAM H.

: Or. The Testudinata of New Hampshire. Proc. Mancliester [N. H.] Institute of Arts and Sciences, vol. 2, 1). $47-51$.

"JAGARE:."

'93. [Golden Eagle captured at Bartlett, N. H.] Forest and Stream, vol. 40, 110. 9, p. I 79.

JENKINS, W. E.

'84. [Note on Loons at Northwood, N. H.] Ornitlologist and Oologist, vol. 9, 110. 2, p. 23.

JOHNSON, J. H.

'92. Bird notes from central New Hampshire, winter of I 89 I92. Ornitlologist and Oologist, vol. I7, 110. 5, p. 72.

JOSSEI, YN, JOHN.

1672. New Iingland's rarities discorered, in birds, beasts, fishes, serpents, and plants of that country. Lonclon.

KNIGH'T', ORA IV.

'97. A list of the birds of Maine, etc. 13ull. no. 3, dep't of natural history, Univ. of Maine; $84 \mathrm{pp}$.

LIT'TLE, WVILLIA M.

'7o. 'The History of Warren, *** New Hanuslire. Manchester.

MACI,EOD, ALBIRTA A.

: oo. Warblers. Nature Study (Mancliester), vol. I, 10. 7 , p. 97-102.

MAYNARD, C. J.

'72. A catalogue of the hircls of Coos Co., N. 湔, and Ox- 
ford Co., Me., etc. Proc. Boston soc, nat. hist., vol. $\mathrm{r}+\mathrm{p} \cdot 357-385$.

MIIIZER, JAS. P.

'90. [Evening Grosbeak] In New Hanpshire. Ornithologist and Oologist, vol. 15, no. 2, p. 28.

'9ı. The Black Gyrfalcon in Vermont [N. H.]. Ornithologist and Oologist, vol. I6, no. 5, 1). 79.

97. I,ittle Blue Heron in New Hampslire. Ank, vol. I4, 110. $3,1 \% .316$.

MIERIAN, C. H.

'9S. Life zones and crop zones of the United States. Bull. no. IO. U. S. dep't agriculture, division of biological survey, p. I-79; map.

MERRILI, HARRY.

'S2. Maine notes. Bull. Nuttall orn. club, rol. 7, no. 3, p. I 90 .

MILLER, G. S., JR.

'91. Further Cape Cod 11otes. Auk, rol. 8, no. I, p. 117.

MINO'T, H. D.

76. The smmmer birds of the White Mountain region. Amer. Naturalist, vol. ro, no. 2, p. 75-So.

'77. 'The land and game birds of New England.

MORRIS, R. O.

: or. The birds of Springfield and ricinity. Springfield, Mass.

MURDOCH, JOHN.

78 . Report of the second capture of the Orange-crowned Warbler (Helminthophaga celata) in New Hampshire. Bull. Nuttall orn. club, vol. 3 , no. 2, p. 96.

NASH, J. IV.

'88. Winter Notes. Ornithologist and Oologist, vol. 13, 110. 7. p. I Oै- $_{4}-105$.

NOR'TON, NED.

's3. Owls-Pine Grosbeaks. Forest and Stream, rol. 20, p. 26.

's 4a. [Hawk Owl at Colebrook, N. H.] Forest and Strean, vol. 22, p. 247.

's b. [Haw' Owls at Colebrook, N. H.] Forest and Stream, rol. 23,110 19, [1. 36s. 
"N. U." [Ned Norton?].

'83. The Pine Grosbeak's summer home. Forest and Stream, vol. 20, p. 36 .

NUT'TALL, THOMAS.

'32-'34. A Minulual of the Ornithology of the United States and Canada. 2 vols. Cambridge.

OLIVER, D. L.

:02. The Catbird wintering at Concord, N. H. Auk, vol. 19. no. 2, p. 208-209.

OSGOOD, F. B.

'9r. Shore bird shooting on the New England coast. XII. Shooting and Fishing, vol. 9, 110. 21, p. 9-10.

ORNITHOLOGIST AND OOLOGIST, ED.

'82. [Bald Eagle at Portsmouth.] Vol. 7, 110. 13. 1. 100.

PALMER, CHARLES.

'7r. Ornithological notes. Amer. Naturalist, vol. 5, no. 2 , p. 120.

"P. C."

'89. New Hampshire bird arrivals. Forest and Stream, vol. 32 , p. 275 .

PEABODI, WM. B. O.

'41. A report on the ornithology of Massachnsetts. Boston journ. nat. hist., vol. 3 , nos. I. 2.

" PINFEATHER ORNITHOLOGIST."

:or. Three Rare Birds. Nature Study: (Manchester), rol. 2 , 110.2, p. 33-34.

:02. Suyder. Nature Study (Manchester), vol. 2, 110. 10, p. $170-174$.

PRIMIE, W. C.

'89. The Northeru Phalarope (Phalaropus lobatus) in the Iiranconia Mountanis, New Hampshire. Auk, vol. 6, 110. I, p. 68 .

PURDIE, H. A.

'73. Notes on some of the rarer birds of $\mathrm{New}$ Engrand. Amer. Naturalist, vol. 7, no. is, p. 692-693.

R. UNDLI:T'T, I. J.

'97. A Snowy Owl in an ice-house. Osprey, vol. 2, no. 1, p. 12. 
"SAMOURAI."

'76. [Gumner's notes from Rye Beach.] Forest and Strean, vol. $7, \mathrm{p}, 102$.

SAMUELS, E. A.

67. Ornithology and Oology of New England. Boston, ill. SANBORN, ED WARD D.

'75. History of New Hampshire. Manchester.

SHA W, S. ALBER'T.

'85. Bittern [at Hampton, N. H.] Ornithologist and Oologist, vol. 10, 110. 2, p. 30.

'87. Nesting of the Virginia Rail in New Hampshire. Ornithologist and Oologist, vol. I2, no. 8, p. 13 I.

SPA ULDING, F. 13.

'86. [Wintering of Robins at Lancaster, N. H.] Ornithologist and Oologist, vol. I I, no. 5, p. So.

'87. Nesting of the Yellow-bellied Sapsucker in New Hampshire. Ornithologist and Oologist, vol. 12, no. 8, p. 1.33 .

'93. Nesting of the Saw-whet Ow1. Ornithologist and Oologist, vol. $18,110.8$, p. II 2 -II3.

'94. Nesting of Wilson's Black-capped Warbler. The Nidiologist, vol. 2, 110. 1, p. 13 .

'95. The Cowbird wintering in New Hampshire. Auk, vol. I 2 , 110.2 , p. I 82 .

'98a. Leach's Petrel at Lancaster, N. H. Auk, vol. 15. 110. I, p. 5 o.

'98b. [Set of five eggs of Spotted Sandpiper at Lancaster, N. H.] Osprey, vol. 3 , 10.3, p. 45 .

SPEI,MAN, H. M.

'Sra. The Great Carolina Wren. (Thryothorus ludoricianus) in New Hampshire. Bull. Nuttall orn. club, vol. 6, no. 1. p. 54 .

'srb. Occurrence of Baird's Sandpiper (Tringa bairdii) on the New Hampshire coast. Bull. Nuttall orn. club, vol. 6 , no. I, p. 6 I.

'82. The Short-billed Marsh Wren in New Hampsline. Bull. Nuttall ori1. club, vol. 7 , no. 2, p. 1 is.

SPINNEY, H. L.

'98. Migration of birds at Seguin I,ighthouse. The Musenm (Allion, N. Y.), vol. 4, no. 5, p. 67-70. 
THAXTER, CELIA.

'70. Among the Isles of Shoals. III. Atlantic monthly, rol. 25, Feb., p. 204-2 I3.

THAYER, G. H.

:02. Some sonthern New Hampshire and western Massachnsetts notes. Auk, vol. I9, 110. 3. 1). 294-297.

TORREY, BRADFORD.

'S+. Bird-gazing in the White Mountains. Atlantic monthly, vol. $5+$ July, p. 5I-59.

'S9. The Killdeer Plover (Agialitis acifcra) wintering on the New Eingland coast. Auk, rol. 6, 110. 3, p. 274 .

'9o. June in Franconia. Atlantic montlily, rol. 65, Ang., p. $2+8-25$.

'96. Some 'Tennessee bird notes. Atlantic monthly, vol. 77. Feb., p. 198-207.

97. A Carolina mountain pond. Atlantic monthly, vol. So, Sept.. p. 383-393.

:oo. May in Franconia. Atlantic monthly, rol. 85, May, p. 628-639.

: oI . Franconia Skylarks. Boston evening transcript, Wed., Ju11e 12, 1901 .

WEBSTER, FIIIEN E.

: ooa. White-winged Crossbills and Brunnich's Murres in central New Hampshire. Auk, vol. $17,110.2,1$. 175-176.

: oob. Ring-billed Gull in New Hampshire. Ank, vol. 17, no. 2 , p. 169.

IVEEED, C. M.

'98. The feeding habits of the Chipping Sparrow. Bull. 55 . N. H. college exp. station, p. IOI-I10, fig. I.

" IV. H. B."

96. [Snipe wintering at Nashua, N. H.] forest and Stream, vol. $4^{6}, \mathrm{y}^{2}, 25^{8}$.

WOR'THEN, 'T'. W. I).

'91. A list of vertebrates found within thinty miles of Hanover, N. H. Hanover, p. I-29, map.

WRIGHT, H. W.

: O2. Birds of Jefferson, N.H., and the northern slope of the P'residential range, etc. Anongr the clouds, vol. 26. 110. 45, p. 4 . 


\section{INDEX.}

('The numbers in italies refer to the annotated list.)

I

abicticola, Ceophloxus p., 27, 4.4. $1 / 1$.

Acadian Slaarp-tailed Sparrow, $/ f^{\prime}$. acarlica, Nyctalia, 47, 106.

Acanthis h. exilipes, $19 I$.

Acanthis linaria, 136 .

Acanthis 1. rostrata, 1,36 .

acaule, Cypripedium, 45.

Accipiter atricapillus, 47,97.

Accipiter cooperii, 27, 97 .

Accipiter velox, 97.

accipitrinus, Asio, 10 .

Actitis macularia, 29, 99 .

acuta, Anas, 28.

acuta, Dafila, $28, \quad r s 9$.

aedon, Troglodytes, 32, $4 \mathrm{I}, 173$.

E.gialitis meloda, 190 .

Egialitis semipalnata, 30, $9 r$.

Egialitis vocifera, 29, 91, 192.

arneus, Quiscalus q., 27, 41, 131 .

astiva, Inendroica, 42, 54, 150.

Eistrelata lasitata, 69 .

affinis, Aythya, 77 .

Agelaits plicuiceus, $27,39,40,54$, 129.

agilis, Geotllypis, 168 .

Aix sponsa, 28,73 .

Alauda alpestris, 3 I.

Alauda magna, 31 .

alba, Ardea, 29.

alba, Quercus, 41.

albeola, Anas, 28.

albeola, Charitonetta, $28,7 \neq$.

albibarbis, Sorex, 47.

albicollis, Zonotrichia, 40, 47, 49, 5I, $1+1$.

Alea artica, 29.

Alea impenuis, 29.

Alca torda, $33, I S S$.

Alcedo alcyon, 27.

alcyon, Alcedo, 27 . alcyon, Ceryle, 27, 110.

Alder Flycatcher, 121.

aliciæe, Hylociclila, $18 \%$.

Alle alle, 65.

alle, A11e, 65 .

alnorum, Empidonax t., $12 \%$.

alpestris, Alauda, $3 \mathrm{I}$.

alpestris, Otocoris, 31, 122.

Alpine Azalea, 52.

aluco, Stris, 27.

American Bittern, 79.

Anericau Brown Creeper, 44, 175.

Anerican Coot, $s_{t}$.

America11 Crossbill, 137 .

American Crow, 127 .

Anerican Egret, $81,1 S 9$.

American Eider, 75 .

American Golden-eye, 56, $7 \%$.

American Golden l'lover, $9 \%$.

Anerican Goldfinch, 52, 136 .

American Goshawk, 47, 97 .

Anerican Hawk Owl, $108,193$.

American Long-eared Ow1, rof.

American Mergauser, 70 .

Anerican Osprey, 107 .

Anerican Pipit, 171 .

American Redstart, $17 \mathrm{r}$.

American Robin, 52, 5.4, 185 ,

American Rougli-legged Hawk, 99.

American Scaup Duck, 73.

Anerican Scoter, 75 .

American Sparrow Hawk, 103.

American Three-toed Woodpecker, 47,112 .

American White Pelican, 70 .

American Widgeon, 72 .

Anterican Woodcock, 85 .

americana, Aythya, $1 S 9$.

americana, Certhia f., $27,44,175$.

americana, Clangula c., $28,7 \neq$.

anericana, Fulica, $s_{f}$.

antericana, Mareca, 28,72 . 
antericana, Mnstela, 47, 52. anericana, Oidemia, 75 .

americanus, Bufo, 46 .

antericanus, Caprimulgus, 33 .

antericanus, Coccyzus, $109,193$.

anericanus, Corvus, $27,127$.

anericants, Cuculus, 27.

annericanus, Merganser, 29, 70 .

antericanus, Parus, 32.

antericantus, Picoides, $47,1 / 2$.

americanus, Tympanuclus, $1 \mathbb{S}_{7}$.

americanus, Ursus, 47.

Ammodramus caudacutus, 1.70 .

Ammodramus c. subvirgatus, 1,7 .

Ammodranns henslowii, 42, 139.

Amnodramus miaritimus, $I / I$.

Ammod ramus princeps, $135,191$.

Annodranus s. savanna, $39,43,52$, 139.

Ammodranus s. passerinus, 41, 139 .

Ampelis cedrorum, 31,150 .

Ampelis garrulus, 31,150 .

Anas acuta, 28.

Anas albeola, 28.

Anas arborea, 28.

Anas bernicla, 28 .

Anas boschas, $7 I$.

Anas buceplala, 28.

Anas crerulescens, 28 .

Anas canadensis, 28.

A nas clangula, 28 .

Anas cygnus, 27.

Anas discors, 28.

Anas erythropus, 28.

Anas fusca, 28 ,

Anas listrionica, 28 .

Anas liyemalis, 33 .

Anas 1uollissima, 28 .

Anas nigra, 28 .

Anas obscura, 28, 72 .

Anas o. rubripes, 72 .

Anas pentope, 28.

Anas spectabilis, 28.

Anas sponsa, 28.

Alias strepera, 28 .

anatum, lialco p., 102.

Anthus pensilvanicus, $17 /$.

antillarum, Stcrna, $29, I S \&$.

Antrostomus vociferus, $33,40,116$.

A plicles, 51.

apricarius, cluaradrius, 30.

Aquila clirysactos, 100 .

arboreă, Anas, 28.

Archibuteo 1. sancti-jolnannis, 99.

Aretic-Alpine \%one, 49.
Arctic Three-tocd Woodpecker, 47 , III.

aretica, Fratercula, 63.

arcticus, I'icoides, 47,111 .

Aretollyys 1110uax, 52.

Ardea alba, 29.

Ardea cierulea, 29, $\delta I$.

Ardea canadensis, 29.

Artea ciconia, 29.

Ardea egretti, $29, \delta 1,1 S 9$.

Ardea lierodias, 29,79 .

Ardea virescens, $29,41, \delta 1$.

Ardetta exilis, 79, 192.

arenaria, Calidris, 29,87 .

Arenaria groenlandica, 52.

Arenaria iuterpres, 190.

arenaria, Tringa, 29.

argentatus, Larus, 29, 66.

artica, Alca, 29.

Asio accipitrinus, 10\%.

asio, Megascops, 27, 40, 106.

Asio wilsonianus, 107 .

Astragaliuus tristis, 32,136 .

ater, Molothrus, 41, 12S.

atricapillus, Accipiter, 47, 97 .

atricapillus, Parus, $32,43,177$.

Auk, Great, 65.

Ank, Razor-billed, $1 S S$.

aura, Cartliartes, 96.

auratus, P'icus, 27.

aturitus, Colymbus, 62.

alrocapillus, Seiurus, $16 S$.

antumualis, Plegadis, $7 S$.

Aythya affinis, $7 t$.

Aythya collaris, $7 f, 192$.

A ytlyya marila, 73 .

Azalea, Alpine, 52 .

\section{I3}

bairdii, Tringa, 86 .

Baird's Sandpiper, 86 .

Bald. fagle, 26, 27, 101 .

Baltiniore Oriole, $39,40,54,56,130$.

baltinore, Oriolus, 27.

lauk Swallow, 32, 1.79.

Bar11 Owl, 27.

Barn Swallow, 32, 1./s.

Barred Owl, 105.

Barreu-gronnd Butterfly, 52 .

Barrow's Golden-cye, $1 \$ 9$.

Bartrania longicanda, 41,89 .

Bartran11an sandpiper, $41, s q$.

bassina, Sula, 29, 69 .

Bay-breasted Warbler, 45, 57, 162.

Beach-bird, 29. 
Bear, Black, 47.

bellii, Vireo, 156 .

Bell's Vireo, 156.

Belted Kingfisher, 110.

bermicla, Anas, 28.

bernicla, Branta, $28,77$.

bewickii, 'Thryomanes, I73.

bewick's Wres, 173 .

bicknelli, IIylocichla a., 47, 49, IS'

Bickuell's Tilrusli, 47, 49, $18 \mathrm{r}$.

loicolor, I'arus, 26, 32 .

bicolor, Tacliycincta, 179 .

bigtlovii, Carex r., 52.

Birel IIawk, 27.

Bittern, Anerican, 79.

Bittern, I, east, 79, 192.

Black and IV'ite IVarble1, 156 .

Black Buar, 47.

Black-bellied I'lover, $9 \%$.

Black-billed Cuckoo, 110 .

Blackbird, Crow, 27.

Blackbird, Red-winged, 27, 39, 40, 51, 129 .

Blackbird, Rusty, 47, $13 \%$.

Black-breasted Plover, 29.

blackburnice, Dendroica, 44, 45, 165 .

Blackburnian Varbler, $44,45,165$.

B1ack-capped I'etre1, 60.

Black-crowned Niglit Iteron, $S_{I}$.

Black I) uck, 28, 72 .

Black Goose', 28.

Black Guillewiot, 63 .

Black Ciyfalcon, IO2.

Black Martin, 32 .

Black-necked stilt, rgo.

Black-poll IVarbler, 47, 49, 57, 163 .

Black 'lern, 68 .

Black-tliroated Blue Warbler, 40, 4.4, 45,160 .

Black-tliroated Green II'arbler, 43 , 165.

blatula, Viola, 46.

Blucbird, 32, 41, 196 .

Blue Goose, 77 .

Bilue-gray Gilatcatclier, '79.

Bluc Grosbeak, $1,6$.

Blue-lieaded Vireo, 43, 4.4, 45, 155.

Blue Heron, 29.

B1ue Jay, 27, 127 .

Blue Trituouse, 32.

Bluc-wingul 'Teal, 28, 73.

Bluisli Cioose, 28 .

Bolblincoln, 32 .

Bobolink, 39, 54, 56, 125 .

lob-white, 41,92 .
Bolı!nian Waxwing, 150 .

Bollaparte's Gul1. 56, 67.

Bonasal u. togatal, 30, 40, 49, 93.

borculis, Isutco, gs.

borealis, Coutopus, $43,44,120$.

borcalis, Ifulius, 27,151 .

borcalis, Nunlenius, 29.

bortalis, Oclocoileus $v ., 47$.

bosclias, Anas, 71 .

Botaurus leutiginosus, 79.

Box 'lortoise, 43.

braclidactyla, Geotlilypis t., 170.

Brant, 28,77 .

Branta bernicla, 28, 77.

Pranta canadensis, 28,77 .

Brent, 28.

Brentlis montinus, 49 .

Broad-winged Hawk, 99.

Bronzed Grackle, 42, 131 .

Brown Coot, 28.

Brown Creeper, 175.

Brown Fagle, 27 .

Brown Flycatclier, 26, 32.

Brown 'Tliraslier, 39, $4 \mathrm{I}, 172$.

Brunnicli's Murre, 57, 63 .

bubo, Strix, 33 .

Bubo virginianus, 33, 107 .

bucciuator, O1or, 78 .

bucepliala, Anas, 28 .

Buff-breasted Sandpiper, $90,192$.

Buffle-liead, $7 \%$.

Bufo anlericallus, 46.

Bunting, Indigo, 39:41, I.77.

Buteo borcalis, $9 \mathcal{S}$.

Buteo lincätus, $g S$.

Buteo platypterus, 99.

Butterfly, Barren-ground, 52.

\section{( )}

carulea, Ardea, 29, $\delta$.

cexulea, Cruiraca, 1.76.

cérulea, Polioptila, 179.

carulescens, Anas, $2 S$.

cerulescens, Chen, 28,77 .

cerulescens, I) endroica, 40, 44, 160 .

Calcarius lapponicus, $19 \%$.

caleudula, Regulus, 54, 179 .

Calidris arenaria, $29,87$.

callace, C'anaclitess c., 30, 45, $17,49$. 92.

Canaclites c. canace, $30,45,47,49$, 92.

Camala Cioose, 77 .

Citlutdat Jay, 47, 125, 193.

Canada I,y11x, 47. 
Canada Porcupine, 47, 52. Canada IV'ite-footerl Mouse, 47. canadensis. Anas, 28. canadensis, Arclea, 29. canadensis, Branta, 28, $7 \%$. canadeusis, Iatuius, 27. canadensis, I,ynx, 47 . canadensis, Muscicapa, 32 . candensis, Perisoreus, $47,125,193$. canadensis, Peromyscus, 47. canadensis, Sitta, 27, 44, 47,176 . canarlensis, Wilsonia, $44,17 /$. Canadian Pine Grosbeak, 47, 48, 59 . 133.

Canadian Red Squirrel, 47.

Canarlian Rufferl Grouse, 40, 49, 93. Canadian Sprnce Grouse, 45, 47, 49, 92.

Canadian Warbler, 44, $17 \%$.

Canaclian Zone, 44.

canus, Larus, 29.

canutus, 'Tringa, 590.

caparoch, Surnia u., $108,193$.

Cape May VVarbler, 47, 57, 159.

Caprimulgus americanus, 33 .

Caprimulgus europatens, 33 .

carbo, Phalacrocorax, 69 .

Carex r. bigelovii, 52 .

caribou, Rangifer, 48 .

Caribou, Woodland, 48.

caroliua, Cistulo, 43.

carolina, Porzana, $30, \delta_{3}$.

Carolina Woodpecker, 26, 27.

Carolina WVren, $38,172$.

carolinensis, Columba, 31.

carolineusis, Galeoscoptes, $32,39,41$, 172.

carolinensis, Muscicopat, 32.

carolinensis, Nettion, 28,72 .

carolinensis, Pandion h.. 33, $10 \%$.

carolinensis, Sitta, 41,176 .

carolinus, Picus, 26, 27.

caroliuus, Rallus, 30.

carolinus, Scolecophagus, $47,5 \%$

Carpodacus purpureus, $43.13 \%$

Carthartes anra, 96.

Caryá, 42.

caspia, Stcrua, $/ 8 \mathcal{S}$.

Caspian Tern, $/ S S$.

cassanus, Pelecauns, 29.

Cassiope hypnoides. 52.

Castántea, 42.

Castanca, Dendroica, 162.

castor, Merglls, 29.

Catbiril, $32,39,41,56,172$.
Caudlacutus, Anmodramus, I.fo.

Cular Waxwing, 150.

cecl rorum, Ampelis, $31,150$.

celata, Helmintlophila, 157 .

Ceophlneus p. abicticola, 27, 44, $1 / \%$.

Cepplius grylle, 63 .

Certhia f. antericana, 27, 44, 175 .

Certhia piuns, 27.

Ceryle alcyoll, 27, 110.

Chetura pelagica, $32,1 / 7$.

Cluaralrius apricarins, 30 .

Charadrius dominicus, $9 \%$.

Charadrius liaticula, 29.

Claradrius uaculatus, 26, 30 .

Charadrius rociferous, 29.

Charitonctta albeola, $28,7 \%$

Cluat, Yellow-breasted, I70.

Chaulelasmus streperus, 189 .

Cheeweel, 32.

Chelopus guttatus, 43.

Clien carulescens, 28,77 .

Chen liyperborea, 28,77 .

Clierry bird, 31 .

Chestuut, 42.

Chestmut-sided W'arbler, 39, 162.

Clickadee, 43,177 .

Chickadee, Hudsonjan, 47, 49, 177 .

Chimney Swallow, 32 .

Chimney Swift, $1 / 7$.

Chionobas semirlea, 52 .

C'hipping bircl, 32.

Chipping Sparrow, 41, 1.12 .

Chorleiles virginianus. $33,40,1 / 6$.

chrotorrhinus, Microtus, 47.

clirysactos, Aquila, 100 .

Clirysemys picta, 43.

clirysoptera, II cluinthopliila, 42,157 , 193.

cicoguani, Putorius, 52 .

ciconia, Arolea, 29.

cillerea, Scotiaptex, 105.

Circus luthonicus, $g 6$.

Cistothorus stellaris, $17 \%$.

Cisturlo carolina, 43.

clangula, 1 nas, 28.

Clangula c. ame ricana, $28,7 \%$

Clangula islandica, $/ S g$.

Clapper Rail, $/ 89$.

Cliff Siwallow, I.jS.

Climbing Ficru, 42.

clypeata, Sipatula, 73, 192.

Coccotluanstes vespertiuns, 132, 193.

Coccy\%us antuericanus, $109,193$.

Coccyzus erythroplithalmus, 27, //0.

Colajte:s a. luteus, $27, / 15$. 
colchicus, Pluasianus, $/ \delta_{7}$.

Colinus rirginian1

collaris, Aythya, 7t, 192.

colubris, Irocliilus, $27,11 S$.

Colnuba carolinensis, 31 .

Colmunta migratoria, 31 .

colunbarius, Iialco, 27, 103.

columbianus, Olor, 27, 77, 192.

Colymbus auritus, 62 .

Colyrulus glacialis, 33 .

Colynubus lolbuellii, 62.

Colymbus in111er, 20.

Colynubus podiceps, 33 .

Cominion I'er11, 67.

Connuon IVre11, 32.

Connpsotilypis a. 11sneat, $15 \mathrm{~J}^{\circ}$.

Connecticut Warbler, $16 S$.

Contopus bortalis, $43,44,120$.

Contopus virens, 120 .

cooperii, Accipiter, 27, 97.

Cooper's I Iawk, 97.

Coot, Anerican, $\mathcal{S}_{4}$.

Coot, Brown, 28.

Coot, Whiteliearl, 28.

corax, Corvus, 27.

Corniorant, 56 .

Cormorant, Double-crested, 56, 69 .

coronata, Dendroica, $32,45,47,49$, 160.

Corvus americanus, 27,127 .

Corrus corax, 27.

Corvus c. principalis, 126.

Corvis cristatus, 27.

Cotton-tail, Easteru, 43.

Cowbird, $41,12 S$.

Cranc, 29.

Cranc, Sandliill, S2.

Crean colored Slieldrake, 29.

Creeper, 27.

Creeper, Browis, 44, 175.

crepitans, Rallus, $I \delta 9$.

Crested Flycatcluer, 32, 40, 119.

Cresterl Titnouse, 26,32 .

Crested IVre11, 32.

crinita, Muscicápa, 32.

crinitus, Myiarclus, $32,40,119$.

cristata, Cyanocitta, $27,12.6$.

cristatus, Corvus, 27.

Crosslill, 31.

Crossbill, Anucrica11, 59, $13 \%$.

Crossbil
135.

Crow, 27.

Crow, Anericill, 127.

Crow Blackbirel, 27.
Crynoplitus fulicarius, $S$. .

Circkoo, 13lack-billed, 110.

Cuckoo, Yellow-billed, 109, 193.

Cuckow, 27.

Cuculus americauns, 27.

cucullatus, J.opliodytes, 29, 71 .

Curlew, Crrey, 29.

Curlew, Hurlsonian, go.

Curlew, Large sipecklerl, 29.

Curlcw, I,ong-billerl, go, 192.

curvirostra, J,oxia, 31 .

cyanca, Cyanospiza, 41, 1.77.

Cyanocitla cristata, 27, 127.

Cyanospiza cyanea, $41,1.77$.

cygnulus, Anas, 27.

Cypripedium acaule, 45 .

\section{I)}

Dafila acuta, 189 .

Deer, Northern Virginia, 47.

deglandi, Oidemia, 76 .

delawarensis, Larus, $67,1 S S$.

delicata, Gallinago, 85 .

Jemilroica aestiva, 42, 54, 159 .

Dendroica blackburniae, $44,45,165$.

Denilroica caerulescens, $40,44,160$.

Denclroica castauea, 162 .

Dendroica coronata, $32,45,47,49$, 160.

Dend roica discolor, 42,167 .

Dewilroica maculosa, 40, 44, 161 .

Dendroica palmarnun, 166 .

Dendroica $p$. hypochrysea, 166 .

Dendroica pensylvanica, 39, 162 ,

Dendroica striata, $47,49,57,163$.

Dentroica tigrina, $47,57,159$.

Dendroica vigorsii, 41,166 .

Dendroica virens, 43,165 .

Diapensia lapponica, 52 .

dilopluss, Phalacrocorax, 56, 69.

Dipper, 28.

( liscolor, Dendroica, 42, 167.

discors, Anas, 28.

discors, Querquedula, 28, 73 .

Dobclick, 33 .

Dolichonyx oryzivorus, $32,39,12 S$.

dollesticus, Passer, $I S 7$.

clominicus, Cliaradrius, $9 \%$.

lorsatı11, Fretlizon, 47, 52.

Double-crested Cormorant, 56,60 .

dougalli, Sterna, 67 .

Dove, Mourning, 95.

Dove, Turtle, 30.

Dovekic, 65 .

Dowiteleer, 86 . 
Dow11y Mondlecker, 54, 111 .

dresseri, Somateria, $28,75$.

I) ryobates p. mediat1us, $27,1 / 1$.

Dryobates villosus, $27,43,44,47,110$

I) uck, American Scallp, 7.3 .

Duck, Black, $28,72$.

Dnck, Grey $\|$ ocd, 28 .

Duck, IIarlequin, $75,192$.

Duck, I.esser sicaup, $7 \%$.

I) inck, Red-legged liack, 56,72.

I) uck, Ring-necked, 7٪, 192.

Duck, Rudily, 76 .

D) uck, Sea, $2 S$.

H)ek, fiprig-tailed, $2 \mathrm{~S}$.

Duck, Itookl, 2S, 73.

Duck Hawk, 102.

\section{I.}

Fagle, Bald, 26, 101 .

Eagle, Hrown, 27 .

Fagle, Golilen, 100.

Eastern Cotton-tail, 43.

Fastern Re(l-backed Moune, 52.

Fastern Varying llare, $47,52$.

Fictopistes migratorius, $31.9 \%$

Figret, American, $\delta /, 1 \delta 9$.

egretta, Ardcä, 29. $\delta /, 1 \delta 9$.

Eivler, American, 75 .

Fider, King, $1 S q$.

Flanoides forficatus, 96.

Fimberiza liyemalis, 31.

Emberiza oryzivora, 32 .

Empiclonax flaviventris, 47, 121 .

F.mpidonax minimus, $39,40,122$.

Empirlonax t. alnorum, 121 .

English Plueasint, $1 \$ 7$.

Fipilobium, $4 \mathrm{~S}$.

Fretlizon dorsatum, 47,52 .

Fremuetes occidentalis, 190.

Freunctes pusillus, 29, $\delta_{7}$.

Erismatura jamaicensis, 76 .

erytliroceplialus, Melanerpes, 27, /15, 193.

crytlirocephalus, 1'icus, 27.

erythrogister, Hirumlo, $32,1 / \mathrm{S}$.

erytluromelas, P'iranga, $32,41,1 . / 7$.

erytliroplitlialma, Fringilla, 32.

crytlirophtlialuus, Coccy\%us, 27, 110 .

crytliroplitlialnuws, 1'ipilo, $32,1 . j 6$.

erytliropus, Anas, 28.

erythrorhy'nclios, l'clecanus, 29, 70.

curopicus, Caprimulgus, 33.

Fivening Frostuak, 132, 103.

livotoniys g. ocliraceiss, 52 .

exilipes, Acautlis li., $19 /$. cxilis, Arclutta, 79, 192.

I

Falco columbarius, $27,103$.

Falco fulvus, 27.

Falco lualiactus, 33.

Falco lundsonius, 27.

Falco islandus, $/ 02$.

Falco lencoceplialus, 26.

Falco p. asiatums, 102.

Falco r, obsoletus, 102.

Falco sparrerits, $27,103$.

Fálco subbutco, 33.

furloá, Limosa. 87 .

fuloa, scolopax, 29.

fera, Meleagris g.. 30, 41, $9 \%$.

Fern, Climbing, 42.

Ficld Sparrow, $39,41,1 / 2$.

Fincl, Purple, 43, 56. 13\%

Fish Hawk, 33.

Fisling Gull, 29.

flav', Muscicapa, 32.

flavifrons, Virco, 41,155 .

flavipes, 'Totanus, $\mathcal{S}$.

faviventris, Finpidonax, 47, 121.

Flicker, Northeru, 115.

Florirla Gallinule, 190.

Filycatclier, Alder, 121 .

Flycatcher, 13row11, 26, 32 .

Flycatcler, Crested, 32, 40, 119.

Flycatclier, I, east, 39, 40, 122.

Flycatcher, Olise-sicierl, $43,44,45$, 120.

Flycatclicr, Yellow-bellied, 47, 121.

forficatus, Flanoirles, c6.

Fox Sparrow, 1.15 .

Fratercula arctica, 63.

Fringilla erytliroplitlialnia, 32 .

Fringilla grisea, 26, 32.

Fringilla tristis, 32 .

Fulica anericalla, $\delta . f$.

fulicaria, Triuga, 29.

fulicarius, C'rymophilus, s.f.

fuligirosa, Sterisa. 65 .

fulvus, lialco, 27.

funleus, Sorex, 47.

fusca, Allas, $2 S$.

fusca, Muscicaja, 26, 32.

fuscesceus, Mylociclila, 1 So.

fuscicollis, 'I'ringa, $\$ 6$.

fuscus, Litus, 29.

\section{(i)}

Gatdwall, 189.

gallubla, lcterus, 27,39, jo, 130 . 
Galcata, Gallinula, 190 .

Galcoscoptes earolincusis, $32,39,+1$, 172 .

Callinago delicata, $\$_{5}$.

Galliuntá galeata, 100 .

Gallimule, Floricla, 100 .

Galliutle, Purple, 100.

galloparn, Meleagris, 30.

Gallilct, 29, 60.

garrulus, Ampelis, 31, 150.

Gavia inller, 29, 33, 43, 62.

Gilvia lumme, 63.

groorgiana, Mclospiza, 43, 1.15.

Cootlily juis agilis, 16.5 .

Goothlypis plis adelplia, $40,44,160$.

Geothlypis t. braclidactyla, 170 .

Geumi, l'cek's, 52.

G(2)111 r. peckii, 52 .

gilvus, Vireo, 15.

glacialis, Colyulsus, 33.

glacialis, Porlismu, 49.

Glancous Gi11, 66, 102 .

glancus, Jarus, $66,192$.

Glossy Ibis, $7 \mathcal{S}$.

Guateatclier, Blue-gray, 179 .

Godwit, Hudsonian, $I 90$.

Gorlwit, Marlsterl, 8 \%

Golden-crowned Kinglet, $44,47,49$, 178 .

Goliten Kagle, roo.

Colden Robin, 27.

Golilen-eye, Anerican, 56, 7\%.

Golden-t’ye, Barrow's, $I S q$.

Golden-winged Warbler, 42, 157, 193.

Golden-winged Woolpecker, 54.

Gold Fincli, 27.

Goldfincli, American, 52, 136 .

Goose, Black, 28.

Goose, Blue, 77.

Goose, Pluisli, 28 .

Goose, Canarla, 77 .

Goose, Lesser Snow, 77 .

Goose, Swall, 28.

Goose, White, 28 .

Goosc, IVilı, 28.

Goshawk, Anerican, 47,97.

Grackle, Browzerl, 42, 131 .

Grackle, Purple, 191 .

Gracula quiscula, 27.

graculus, Pelecants, 29.

gramineus, Pooectés, $39,40,13 S$.

Grape Birrl, 32.

Grassliopper Sparrow, 4 I, 139.

gravis, Puffinus, $1 S Q$.

Gráy Squirrel, 43.
Grity-cleceked 'Ylirush, $/ S /$.

Groat Auk, 65.

Groat Black-latcked Cin1l, 66 .

Great Bluc IItron, 79.

Great Gray Ow1, 115.

Creal Horned (Ow1, 107.

Great Rerl-crested Woorlpecker, 27.

Greater Rerlpoll, 36.

Greater Silearwater, $/$ so.

Grealer Iellow-legs, $\delta S$.

Grele, Holbcell's, 62.

Grebe, Horned, 56, 62 .

Grebe, Pierl-billed, 62.

Green Heroll, 51, $S_{t}$.

Greenland Sanelwort, 52.

Green-winged 'Teat, 28,72 .

Grey Curlew, 29.

Grey Gull, 29.

Grey Woorl Duck, 28.

grisea, Fringilla, $26,32$.

grisens, Macrorlianuphus, $\$ 6$.

greenlandica, Arenaria, 52.

Grosbeak, Plue, $1 . j 6$.

Grosbeak, Canarlian Pinc, 47, 48, 59, 133.

Grosbeak, Evening, 132, 193.

Grosbuak, Rose-breasted, 1,6 .

Crouse, Canadian Ruffed, 39, 49, 93.

Grouse, Canadian Spruce, $45,47,49$, 92.

Growse, 30 .

Grus mexicana, 29,82 .

grylle, Cepplius, 63.

Guillemot, Black, $6_{3}$.

Guiraca caerulea, 1.j6.

Gin11, Bonaparte's, 56, 67 .

Gull, Fislining, 29.

Gul1, Claucous, 66, 192.

Crull, Great Black-backerl, 66.

Giull, Grey, 29.

Gull, Herring, 66.

Gu11, Mackere1, 29.

Gul1, Ring-billed, $67,1 \$ s$.

Gu11, I'11ite, 29.

guttatus, Cliclopus, 43.

gymnicus, Sciurus 11., 47.

Gyrfalcoll, Black, 102 .

Gyrfalcon, W'lite, roz.

\section{H}

lia miastica, I imosa, 190.

Hairy IVoolpecker, 43, 44, 47, 110.

I Ialicetus leucocephalus, 26, 27, $10 /$.

haliaetus, Falco, 33 .

Hangbirel, 27. 
Halugbirr, I,ittle, 32.

Hare, Fistern Varying, 47, 52 .

Harella hyenalis, $2 S, 33,75$.

Harlequin Duck, 75, 192.

lasitita, Fistrulata, 60.

Hawk, American Rough-leugsed, 99.

Hawk, Anerican Sparrow, 103.

Hawk, Birl, 27.

Hawk, Broad-winged, 99.

Hawk, Cooper's, 97.

Hawk, Duck, 102.

Hawk, Fish, 33 .

Hawk, Hen, 27.

Hawk, I arge Browi1, 27.

I awk, Marsh, 96 .

Hawk, Pigcon, 27, 33, 103.

Ifawk, Reil-showlered, $9 S$.

Hawk, Red-tailed, gS.

Hawk, Shirp-shin!cul, 97.

Hedgebird, 32.

Iteluintlophila celata, 157 .

Helminthopliila clirysoptera, 42, 157 , 193.

Heluintlophila peregrina, 47,158 .

Helminthophila rubricapilla, $4.3,47$, 49, 157 .

Helmitherus vermivorus, 156 .

Helodromas solitarius, 29, SS.

IL'1 Hawk, 27.

Hen, Prairie, $1 S_{7}$.

Hen, IVater, 29.

henslowii, Ammodranus, 42, 139.

Henslow's Spartow, 42, 139.

Hermit 'Thruslı, $40,43,45,1 \delta /$.

herodias, Aricea, 29, 79 .

Heron, Black-crownci Niglit, 81 .

Heron, I3lue, 29.

Heron, Great IBlue, 79.

Heron, Green, $41, s_{j}$.

Heroll, I ittle lilue, $S_{l}$.

Ieron, IVlite, 29.

Herring Gull, 66.

liaticula, Cluaralrius, 29.

Iickory, 42.

hiemalis, Olliorchilus, $44,47,173$.

Hinantopus nexicanus, 190 .

himantopts, Micropalinua, $86,192$.

hirundenaceus, l'icus, 27.

Hirumilo erytlirogister, 32, $1 / 5$.

Iirundo pelasgia, 32.

II irume purpurea, 32.

Hirundo riparia, 32 .

Hirumdo subis, 32 .

hirunclo, Sterua, 29,67.

listrionica, Allas, 28.
Histronicus histrionicus, 2S, 75, 192. histrionicns, Histrionicus, $2 \mathrm{~S}, 75,192$. Hoary Redpoll, 191 .

bolbceilii, Colyunbus, 62.

IIolball's Grebe, 62.

Hoorled Merganser, $\pi$.

Horned Grube, 56, 62 .

Horned Iark, 122.

Horned Uw1, 33.

IIouse sparrow, 197 .

House ITret1, 41, 173 .

II udsonian Chickadee, 47, 49, 177.

II udsonian Curlew, go.

IIndsonian Golwit, 190 .

Hulsonian /one, $4 \mathrm{~S}$.

ludsonicus, Numenius, 29, go.

hudsonicus, Parns, 47, 49, 177.

liulsonius, Circus, 96.

hurlsonius, Fialco, 27.

Humility, 29.

II numingbird, 27.

I unw1uinglird, Kuby-tlroated, $1 / S$. Ifydrochelirlon 11. surinanensis, $6 S$.

liyenatis, Anas, 33.

liyenalis, Finberiza, 31 .

liyculalis, I Iarelda, 28, 33,75 .

liyenualis, Junco, $31,40,45,47,49,51$, 173.

Hylociclila alicice, $I S I$.

Hylocichla at bicknelli, $47,49,18 \%$.

II vlocichla fuscesce1s, $I S^{\prime}()$.

Iy rocichla g. p.llasii, 40, 43, 45, $15 \%$. Hylociclila 11 ustelinas, 39, 40, 179 .

I y locichla u. swaiasonii, $44,47,1 S_{3}$. liyperloorea, Clicil, 28, 77.

lypuoicles, Cassiupe, 52.

liypochrysca, Deuchroical p., 167.

\section{I}

Ibis, Glossy, $7 S$.

Icteria virciss, 170 .

icterocepliala, Motacilla, 32.

Icturus (aillonlal, 27, 39, 40, 30 .

icterus, Oriolus, 27.

Icterus spurius, $3 \mathrm{~S}, 19 /$.

iliaca, Passerellit, $1 / 5$.

imber, Craria, 29, 33, 43, 62.

inunuer, Colyulbus, 29.

impentis, Aleil, 29.

inupenuis, l'lantus, 29,65 .

Inligo Bunting, 39, f(), 1.17.

iusigruis, Napeozapus, 47.

interpres, Arenaria, los.

interjores, Tringil, 29.

Ionornis mutinici, $J g()$. 
Ipswicl Sparrow, 38 , 191. islandica, Claumgula, rso. islandus, Jitlco, 102 .

\section{.)}

Jaceger, Parasitic, 66. jamaicensis, Jirismatura, 76 . Jay, Bluc, 27, 12\%.

Jay, Callada, 47, 125,193 .

Junco liyemalis, $31,40,45,47,49,51$ 1.13 .

Junco, Slate-colorerl, 40, 45, 17, 49, $51,1.13$.

\section{li}

Kalmia latifolia, 42.

Kildee, 29.

Killilecr, 91, 192.

Kingloird, 27, 39, 40, 1/9.

King Fider, 189 .

Kingfisher, $27,5 \uparrow$.

Kingfisher, Belted, 110 .

Kinglet, Colden-crownerl, 44, 47, 49, $17 \mathcal{S}$.

Kinglet, Ruby-crownerl, 179 .

Kite, Swallow-tailer, 96.

Kittiwake, 66 .

kinot, 100 .

\section{I.}

Lady's Slipper, 45.

Ianius borealis, 27, 151 .

Ianius canadensis, 27.

Lanius ludoricianus, 11,151 .

I anius tyraunus, 27.

I apland Longspur, $/ 9 /$.

lapponica, Jiapensia, 52,

lapponica, Scolopax, 29.

lapponicum, Rhododendron, 52.

lapponicus, Calcarius, 191 .

large Brown lawk, 27.

I arge speckled Curlew, 29.

Iarge Spotted I, oon, 33 .

Iarge Spotted Plover, 26, 30.

Jark, Horned, 122.

I,ark, Marslı, 31 .

Iark, Prairie II orned, 123.

lark, Sky, 31 .

I arus argentatus, 29, 66 .

Iaris callus, 29.

Iarus delaware1usis, $67,7 S S$.

Larus fuscus, 29.

Jarus glatucus, $66,192$.

Iarus matrinus, 66 .

Iarus plidadelpliia, 67. larus ridibundus, 29

latifolia, Kalluia, 42.

Iantel, Mountiin, 42.

1. eitch's l'etrel1, 69.

J.east bitter $1,79,192$.

I. cast [i] ycatclicr, 39, 40, 122.

I, catst sandpiper, $56, s_{7}$.

I, east 'Fern, /S8'.

lentiginosus, Botaurus, 79.

I,cpus a. virginianus, 47, 52 .

l,epus f. transitionalis, 43 .

Jusser Scaup I)uck, 7.7 .

lesser Sinow Goose, 77 .

leucoceplialus, lialco, 26.

leucoccplialus, Halicetus, 26, 27, 107 .

leucoplirys, Zonotrichia, $/ 1 /$.

lencoptera, loxia, 47, 49, 135 .

leucorhoat, Occanod romit, 33, 60.

leucotis, Sciurus c., 43.

leucura, l'inicola $\ll .44,133$.

life Zones, $3^{8}$.

linosa fedoa, $S_{7}$.

Iimosa liámastica, 190.

linaria, Acanthis, 136 .

lincolnii, Melospizá, $1 / \%$.

lincoln's Sparrow, I.ff.

lineatus, Buteo, gs'.

linnet, Red, 32.

Little Blue Heron, $8 \%$.

I ittle Brown Weasel, 52.

I,ittle IIangbird, 32.

lobatus, I'lalaropus, $\& /$.

Ioggerliead Slirike, 4L, 15\%.

I,oiselenria procumbens, 52.

lonvia, Uria, 33, 63 .

Long-billed Cinrlew, go, 192.

longicanda, Bartrania, 41, $\$ 9$.

longirostris, Numenius, 90,192 .

I,ongspur, I,apland, 101 .

$\mathrm{H}, 0011,29,43,62$

1,oo11, I,arge Spotter1, 33.

I,oo11, Redi-tliroated, 56,63 .

I.ophodytes cucullatus, 29,71 .

forrl and I,ady, 28.

J,ouisiana Water-Thruslı, 169.

I,oxia curvirostra, 31 .

I,oxia c. minor, $31,13 \%$

Loxia leucoptera, $47,49,135$.

ludoviciana, Zannelodia, 1,6 .

ludlovicianus, Línius, 41, 151.

ludovicianus, 'Pliryotlorus, $38,172$.

linu11e, Cávia, 63.

lumifrons, Petrochelidon, $1 . / \$$.

luteus, Colaptes a., 27, 115 .

Lygodium palmutum, 42. 
Lynx, Canada, 47.

I,yux canadensis, 47 .

lysteri, Tamias s., 52 .

\section{II}

Mackerel Gull, 29.

Macrorhamphus griseus, $\delta 6$. macroura, Zenaiclura, 95. macularia, Actitis, 29, 90 . maculata, Tringa, 29,86 . maculatus, Cliaradrius, 26, 30 . maculosa, Dendroica, $40,43,45,161$. maculosus, Picus, 26, 27.

magna, Alauda, 3 I.

magna, Sturnella, $31,39,130$.

Magnolia Warbler, $40,43,45,16 \%$.

Mallard, 28,71 .

Marbled Godwit, $8_{7}$.

Mareca americana, 28, 72 .

marila, Aythya, 73 .

marilandicus, Tetrao, 30 .

marinus, Larus, 66.

maritima, Tringa, 190.

maritimus, Ammodramus, $1 / f$.

Mirsh Bird, 29.

Marsl Hawk, 96.

Narsh Lark, 31.

Marten, Penisant's, 47.

Martin, Black, 32.

Martin, Purple, 54, 1.77 .

martinica, Ionornis, 190.

Masked Slirew, 47.

maximum, Rlododendron, 42.

Meadowlark, 39, 130.

Mechquan, 25.

medianus, Iryobates p., $27,1 / 7$.

Medrake, 67.

Megascops asio, 27, 40, 106,

Melanerpes erythrocephalus, 27, 1/5. 193.

melanoleucus, Totanus, $S \&$.

Neleagris gallopavo, 30.

Meleagris g. fera, $30,41,9 \%$.

melodá, Aigialitis, 190 .

unclodia, Melospiza, 32, 39, 1.\%

Melospiza gcorgiana, $43,1.15$.

Melospiza lincoluii, $\% \%$.

Mclospiza melorlia, 32, 39, $1 . / 1$.

Merganser, Anerican, 70.

Merganser, Hooled, $7 \%$.

Mergalsser, Reel-breasted, 71.

Merganser americanus, 29, 70 .

merganser, Mergus, 29.

Merganser serrator, 29, 77 .

Mirgus castor, 29.
Mergus merganser, 29.

Mergus serrator, 29.

Ierula migratoria, 31,185 .

uexicana, Grus, 29, $\delta_{2}$.

mexicanus, Himantopus, 190.

Micropalansa himantopus, S6, 192.

Microtus chrotorrhinus, 47 .

Migrant Shrike, 4 I.

migratoria, Columba, 31 .

migratoria, Merula, 31, 185 .

migratorius, Ectopiste's, 31, 9.\%.

migratorius, Turdus, $3 \mathrm{I}$.

Minus polyglottos, 191 .

minimus, Empiclonax, 39, 40, 122.

Mink, 47 .

minor, Loxia c., 31, $13 \%$.

minor, Philohela, 29, 85 .

minuta, Sterna, 29.

minutilla, Tringa, $\delta_{7}$.

Mniotilta varia, 156 .

Mockingbird, 191 .

mollissima, Anas, 28.

Molothrus ater, $41,12 \delta$.

monax, Arctomys, 52.

monticola, Spizella, 32, r.t2.

montinus, Brentlis, 49.

morinella, 'Tringa, 29.

Motacilla icterocephala, 32 .

Motacilla regulus, 32 .

motacilla, Seiurus, 168.

Motacilla sialis, 32 .

Motacilla trocliilus, 32 .

Mountain Laurel, 42.

Mourning I)ove, 95.

Motrning Warbler, 40, 44, 57, 169.

Mouse, Canarla White-footed, 47.

Mouse, Fastern Red-backed, 52.

Mouse, Woodland Jumping, 47.

MIurr, 33.

IIrre, Brunnich's, 57,63.

Muscicapa canalensis, 32 .

Muscicapa carolincusis, 32 .

Muscicapal crinita, 32.

Iuscicapa flava, 32 .

Muscicapal fuscat, 26, 32 .

Mustelat antericanat, 47,52 .

Mustela pennanti, 47 .

mustelina, Ifylociclıla, 39, 40, 179 .

A yiareluss crinitus, $32,40,119$.

Mlyrtle Warb](r. 45, 47, 49, 55, 57, 160 .

$\mathrm{N}$

natevins, Nycticorax n., 29, $s /$.

Nat)ico\%alus insignis, 17.

Nishiville W'arbler, 4,3, 47, 49, 157. 
nebulosum, Syruium, 27, 105.

Nettion curolinensis, 28,72 .

Niginthisk, 33, 40, 55, 1/6.

nigra, Aluas, 28.

nivalis, Passerint, 31,137 .

Northerı Flicker, $1 / 5$.

Nortlern Parula IVarbler, $/ 5 S$.

Northeru Plialarope, $\delta$.

Nortlern Pileated IVu, lpacker, 4 t. I/.7.

Nortlerin Ravent, 126.

Nortinern Shrike, $15 \%$

Nortlern Virginia I)cer, 77.

Nortliern Yellow-throat, 170.

No Tail, 33.

noveboracensis, Porzalla, 199 .

noveboracensis, Seiurus, 44,168 .

Nyctala acarlica, 47,106 .

noveboracensis, Vireo, 38,156 .

Numenins borealis, 29.

Numenius lunlsonicus, 29, 9 .

Numenius longirostris, $00,102$.

Nuthatcli, 27.

Nutlatcl, Reil-breasted, 4t, 47, 52, 176 .

Nutlatel, White-breasted, $41,176$.

Nyctala tengmalmi ricliardsoni, 105 , 193 .

Nyctea nyctea, 27, 107 .

nyctea, Nyctei, 27, 107 .

nyctea, Strix, 27.

Nycticorax n. nievin:, 2), 8 /.

Nymphaea variegata, 46 .

Nyssa sylvatica, 42.

\section{O}

Oak, Bear,

Oak, Rerl, 42.

Oak, Wlite, 41.

obscura, Anas, $2 \mathrm{~S}, 72$.

obsoletus, Falco r., 102.

occidentalis, Erennetes, 190.

occidentalis, Pelicanus o., 29.

oceanicus, Oceanites, 60 .

Oceanites oceanicus, 69 .

Oceanodroma leucorlioa, 33, 69.

ochraceus, Fvotonlys g., 52.

Odocoileus $v$. bore 1 lis, 47 .

Oidemia anericana, 75 .

Oiclemia deglandi, 76 .

Oirlemia perspicillata, 28,76 .

Olbiorchilus hiem 1 lis, $44,47,173$.

Old-squaw, 56,75 .

Oldwife, 28,33 .

olivaceus, Vireo, 32, 152 .
Olive- backed Thrush, $44,47,193$.

()live-sided Flycatelier, $43,44,45,120$.

Olor lunccinator, $7 S$.

Olor colum'rianus, 27, $7 \mathcal{S}, 102$.

Orange-crowned Warbler, 157.

Orcliard Oriole, $38,191$.

Oriole, Baltimore, $39,40,54,56,130$.

Oriole, Orcliard, 38,101 .

Oriolus baltimore, 27.

Oriolus icterus, 27.

Oriolus phreniceus, 27.

orplieus, 'Turdus, 3 I.

oryzivora, Emberiza, 32.

oryzivorus, Dolichonlyx, 32, 39, 129.

Osprey, Anerican, $10 \%$.

Otocoris alpestris, $31,122 .^{\circ}$

Otocoris a. praticola, 123 .

Oren-bird, 45, 168 .

Owl, Amcrican Hawk, 10S, 193.

Owl, Anerican Long-eared, 10.7.

Ow1, Barn, 27.

Owl, Barred, 105.

Owl, Great Gray, 105.

Ow1, Great Horned, 107.

Owl, Horned, 33.

Owl, Richardson's, 105, 193.

Owl, Saw-whet, 47, ro6.

Owl, Screech, 40, 106.

Owl, Short-eared, ro.

Owl, Snowy, I07.

Owl, Speckled, 27.

Owl, IVhite, 27.

Ox-eye, 29.

\section{$\mathbf{P}^{3}$}

pacifica, Tringa a., $\delta 7$.

Paintel Tortoise, 43.

pallasii, IIylocichla g., $40,43,45, I 37$.

Palm Warbler, 166.

paliw ir 1111, Dendroica, 166.

palmatum, I,ygorlium, 42.

Pandion h. carolinensis, 33, 10..

Parasitic Jaeger, 66.

parasiticus, Sitercorarius, 66 .

Partridge, 30 .

Parus antericanus, 32 .

Parus atricapillus, 32, 43, 177 .

Parus bicolor, 26, 32 .

Parus hudsonicus, $47,49,177$.

Parus pendulinus, 32 .

Parus virginianns, 32 .

Passenger Pigeon, 97.

Passer domesticus, $I S 7$.

Passerella iliaca, 1.75 .

Passerina nivalis, 31,137 . 
passcrina, Strix, 27 .

passerimus, Immolrailus s.. 41, 139 . l'avoncella pugnax, Sg.

peckii, Geum r., 52.

I'cek's Genin, 52 .

Pectoral Sanclpiper, $\$ 6$.

Peep, 30.

pelagica, Cliatura, 32, 117 .

pelagica, Procellitria, 33.

pelasgia, Hirunclo, 32.

Pulccanus cassanus, 29.

l'ele canus erytlirorliyiclios, 20, $7^{\circ}$.

I'elccauus śraculus, 29.

Jelica11, 29.

l'elican, American IT'hite, 70 .

Pelicantus o. occidentalis, 29.

penrlulinus, I'arus, $3^{2}$.

pentope, Anas, 28.

Penguin, 29.

pen11a11t, MInstela, 47.

Pennant's Marten, 47 .

pensylvanica, Dendroica, $39,162$.

pensilvanicus, Autliss, 171 .

jeregrina, Helminthopliila, 47,158 .

Perisoreus canadensis, 47, 125, 193.

Peromyscus canadensis, 47 .

persoliatus, Sorex, 47.

perspicillata, Oidemia, 29, 76 .

petrel, Black-capped, 60.

Petrc1, I,each's, 69.

l'etrel, Wilson's, 6o.

Pettcril, 33.

Pctrocliclidon lunifroms, $1.7 \$$.

P(-wee, Wood, 120.

l'halacrocorax carbo, 60.

l'halacrocurax dilopluns, $56,6 \%$.

Plialarope, Northern, $S_{/}$.

Phatatrope, Red, $s /$.

I'liala rope, Wilson's, 85 .

plialaropus lobitus, s'f.

phasianus colclicus, 30,157 .

I'luasant, Finglish, 30, rif.

plicalciplia, Geotlilypis, 40, 4t, 160 .

philadelplia, Larus, 67.

Pliblarlelpliat Vireo, 15.3.

plilatclplicus, Virco, 153.

Philohela minor, 29, is.

Phicelue, 40, 120.

plucelue, Sayormis, $32,40,120$.

phoeniceus, Agelaius, 27, 39, 40, 5-1 129.

pluenicuns, Oriolus, 27.

p'icoirles americantus, 47,112 .

Picoirles arcticus, $47,1 / 1$.

pictá, Clirysernys, 43 .
Picus auratus, 27.

l'icus carolinus, $26,27$.

licus crythroceplialts, 27.

Picus hirumlenacens, 27.

Picus uniculosus, 26, 27.

Picus pilcutus, 27.

l'icus pubescens, 27.

P'icus villosus, 27.

l'icrl-billed Grebe, 62.

I'igeon İawk, 27, 33, 103.

P'igeon, l'assenger, 9.t.

l'igron, Scal, 28.

l'igreoll, IVild, 31.

pileatus, I'icns, 27.

Pillian11aw, 25.

Pinc Siskin, 47, 52, 59, 136.

l'ine IV:trbler, $41,166$.

Pinicola e. leucura, 47,133 .

Pintail, $/ S g$.

pinns, Certliia, 27.

pinus, spinus, 47,136 .

Pipilo erythroplitimlinus, $32,7 t^{6}$.

P'iping Plover, 190.

Jipit, Anerican, $17 \%$.

l'iranga erytlironelas, $32,41,177$.

Pirallesa rubra, $1 / 7$.

P'lantus in1pennis, 29,65 .

platypterus, Buteo, 99.

Plegardis antumnalis, $7 \&$.

Plover, American Golden, 91.

J'lover, Black-bulliexl, g1.

Plover, Black-1)reatsterl, 29.

Plover, Large Siputterl, 26, 3n.

Plover, l'iping, 190.

Plover, l’yerl, 3 o.

Ploser, Senuipalmaterl, 91 .

podiceps, Colymbus, 3.3.

porliceps, l'orlilymbus, 33,62 .

l'orlily'ml us policeps, 33, 62 .

P'xliswn glatcialis, 49.

l'olioptila cierulët, 179.

polyglottos, Minu1s, 191 .

lorecctes gramincus, $39,41,138$.

l'oreupine, Canarla, 47,52 .

f'orzatia carolina, $30, \mathrm{~S}_{3}$.

l'orzana novelooracensis, 189 .

P'rairic Hen, I\$7.

Prairic Ilorned I ark , 123.

Prairic Watbler, 42, 167.

1) raticola, Otocoris a., 123 .

princeps, A 11 modranus, $13 S, 191$.

principilis, Corvus c., 126.

I'rocellaria pelagica, 33 .

procunbe 11s, 1,oiseleuria, 52.

Prognc subis, $32,54,1 / 7$. 
pubescens, Picus, 27.

Puffin, 63.

Puffinus igravis, $7 s^{\prime}$ g. pugnax, Payoncella, So. Purple Fincli, 43, 56, $13 \%$. P'urple Cislliumle, roo. Purple Gitackle, ror. Purple Matin, 5\%, $1 / 7$. Purple situlpiper, roe. purpurcis, Hirumlo, 32. purpureus, C.urporlicus, $43,13 \%$ pusilla, Sipizclla, 39, $41,1 / 2$. pusilla, Wilsonia, 47,170 . pusillus, Fireunctes, $29, S_{7}$. Putorius cicosuani, 52.

Putorims vison, 47 .

Pyed Plover, 30.

Pyed Slielldrake, 29.

\section{(2)}

Quail, 30.

Quercus alba, 11,42 .

Querquerlulit discors, 28.73.

Quindar, $2 S$.

Quiscalus quiscula, $19 \%$.

Quiscalus q. xumus, 27, 42, 131.

quiscula, Gracula, 27.

quiscula, Ouiscalus, 191 .

\section{I.}

Rabbit, Fastern Cottontail, 43.

Rail, Clapper, $1 S$ o.

Rail, Virginia, $S_{3}$.

Rail, Yellow, $r S^{\prime} o$.

Rallus carolinus, 30.

Rallus crepitans, $r S^{\prime} 0$.

Rallus virginianus, J’3.

Rangifer caribou, 18.

Raven, Nortlicri1, 126 .

Razor-billed Auk, rss.

Red Linnet, 32.

Red Oak, $f 2$.

Red Phalarope, if.

Red-backed Sandpiper, $\delta_{7}$.

Rerl-bellierl Silelldrake, 29.

Red-breasted Merganser, $7 I$.

Red-breasted Nuthatch, 4.t, 47,52 , $I 76$.

Red-eyed Vireo, 52.

Redliead, 1 so.

Rerllicad Woodpecker, 27.

Rerl-headed Woodpecker, 1/5, 193.

Red-legged Iilack Duck, 56, 72.

Redpo11, 59, 136 .

Redpoll, Greater, 136.

Redpoll, Hoary, $19 \%$.
Re 1-3.10i1l les ? Ir.w's, os.

Rerlstirt, Inutican, $17 \pi$.

Recl-tailed II aw's, $9 S$.

Red-tlroited I, oon, 56, 63.

Reil-inined Blacklird, 27, 39, 40, 54, 120.

Regulus cilten lu1i, 5t, 170 .

Regulus satrat)a, $32,44,17,19,1-8$.

Rlodolendron lapponicmu, 52.

Rhololendron nuxin11111, 42 .

kil)!ou Sin:ke, 43.

richardsoni, Nictala t., I(1)5, 193.

Richurlson': Ow1, 105,103 .

ridibundus, I,arus, 29.

Ring-billerl (rall, 67, 185 '.

Ring-ukcked i)uck, 7\%, 19)

riparia, Hirundo, 32 .

Riparia ripuria, $32,8 / 9$.

riparia, Riparia, 32, $1 / 9$.

Rissat tridactyla, 66.

Robin, 31, 5 t, 56 .

Robin, American, 52, 54, I\$5.

Robin, Golkten, 27.

Rock Bird, 29.

Rock Vole, 47.

Rostate T(1\%11, 6S.

Rose-brcasted (rrosbeak, 1.76 .

rostrati, Ieantluis $1,1,36$.

ru') r.1, Pïtusel, $/ 19$.

rubra, 'T'anzegra, 32.

rubricapilla, Helmintlovluila, 43,47 , $19,157$.

ruloripes, Anas o., 72.

Ruby-crownell kinglet, 5t, 179 .

Riby-crowned Wrein, 5t.

Rab;-throated Hummingloird, $1 / S$.

Rudly I) uck, 76 .

Ruff, $\delta_{0}$.

rifu11, Tox stom: 31, 39. 41, 172.

rufus, Turdus, 3 .

rustica, Scolopax, 29.

Rusty Blateluird, 47, 131 .

ruticilla, Sitoplraga, 171 .

\section{$+4$}

Sable, 47,52 .

Silucti-joh:tunis, Arehibuteo 1., 90.

Sanclerling, $S_{7}$.

Sandlitl Crane, $\$ 2$.

Santpiper, Baird's, $\$ 6$.

Sandpiper, Bartramian, 4, So.

Sandpiper, Buff-breastul, $90,192$.

Samlpiper, Least, $56, \delta 7$.

Simulpiper. Pectoral, $\$ 6$.

Sanclpiper, Purple, 190.

Saurlpiper, Rcrl-backerl, $s_{7}$. 
Sandpiper, Semipalmated, $55, \delta_{7}$.

Sandpiper, Solitary, 88 .

Sand piper, Spotterl, 90.

Sand piper, Stilt, $\$ 6,192$.

Sandpiper, Western Semipalmated, rgo.

Sand piper, White-rumped, $S 6$.

Sandwort, Greenland, 52.

Sapsucker, Yellow-bellied, 44, 45, II3.

satrapa, Regulus, $32,44,47,49,179$.

saurita, Thamnoplis, $4 \hat{3}$.

savauna, Ammodranus s., $39,43.52$, 139.

Savanna Sparrow, 39, 43, 52, 139.

Saw-wliet Owl, 47, 106.

Sayornis plicebe, 32, 40, 120 .

Scarlet Tamager, $41,54,56,8.47$.

Sciuropterus volucella, 43 .

Sciurus c. leucotis, 43 .

Sciurus h. gymnicus, 47.

Scoldenore, 75 .

Scolecopliagus carolinus, $47,13 \%$.

Scolopax ferloa, 29.

Scolopax lapponica, 29.

Scolopax rustica, 29.

Scolopax tota111s, 29.

Scoter, American, 75 .

Scoter, Surf, 76 .

Scoter, White-winged, 76 .

Scotiaptex cinerea, Ins.

Screecli Ow1, 40, 106.

Sea Duck, 28.

Sea Pigeon, 28.

Seaside Sparrow, $r . f$.

Seiurus aurocapillus, 168 .

Seiurus motacilla, 168 .

Seiurus noveboracensis, 44,168 .

semirlea, Clionobas, 52.

semipalmata, Aigialitis, $30,9 /$.

semipalmata, Sympliemia, 190 ,

Scmipalmated plover, $9 \%$.

Semipalmated Sandpiper, 56, 87 .

serrator, Merganser, 29, 7 .

serrator, Mergus, 29.

Setopliaga ruticilla, $17 /$.

Shag, 29.

Sliarp-slinincel Hawk, 97.

Sliarp-tatiled Sparrow, 1.po.

Sliearwater, Greater, $I \$ g$.

Slielldrake, Cream-coloreel, 29.

Slielldrake, Pyed, 29.

Sliclldrake, Red-bellierl, 29.

Sliort-billed Marsh WVrell, 77. .

Sliort-cared Ow1, $10 \%$.
Slloveller, $73,592$.

Slirew, Masked, 47.

Slirew, Smoky, 47.

Shrew, IVater, 47.

Slirike, Loggerliead, 41, 151 .

Shrike, Migrant, 41.

Shrike, Northerı, 151.

Sialia sialis, $32,41,786$.

sialis, Motacilla, 32 .

sialis, Sialia, $32,41,186$.

Siski11, I'i11e, 47, 52,59, 136 .

Sitta canadensis, $27,44,47,176$.

Sitta carolinensis, 41,176 .

Skouk, 29.

Sky Lark, 31.

Slate-colored Junco, 40, 45, 47,49, 51 , 1.13 .

Silloky Slirew, 47.

Sinake, Ribbon, 43.

Sinipe, Wilson's, 85 .

Siripe, WVoorl, 29.

Silowbird, 31, 13S.

Silowflake, $/ 37$.

Snowy Ow1; 107 .

socialis, Spizella, 32, 41, $1 / 2$.

solitarius, Helodronsas, 29, 88 .

solitarius, Vireo, $43,44,355$.

Solitary Sanclpiper, 88 .

Solnateria dresseri, 28,75 .

Somateria spectabilis, 199 .

Song Sparruw, 39, 5\%, 17 .

Siouty 'l"er11, 69.

Sora, $\delta_{3}$.

Sorex albibarbis, 47 .

Surex funcus, 47.

Sorex personatus, 47.

Southern Flying Squirrel, 43.

Sparrow, Acaliall sharp-taliled, 8 fo.

Sparrow, Clipping, 40, $1 / 2$.

Sparrow, Ficld, 39, 41, $1 / 2$.

Sparrow, Iiox, 175 .

Sparrow, Cirasliopper, 41, 139.

Sparrow, Henslow's, 42, 139.

Siparrow, Ilouse, $1 S 7$.

Spatrow, Ipswicli, $13 \delta, / 91$.

Spartow, I,incolis's, I.f./.

Sparrow, Salvall1a, 39, 43, 52, 139.

Sparrow, Seasicle, $1 / f$.

Sparrow, Sliarp-tailed, r,o.

Siparrow, Songs, 39, 54, 4.4 .

Sparrow, Swati1p, 43, 1.75 .

Siparrow, Tree, 1.f2.

Sijarrow, V'esper, 39, 41, 138 .

Sparrow, IVhite-crowned, 1,1 . 
Sparrow, White-throated, $47,49,51$, surinanensis, Ilydroclutiolon 11., 68 .

$$
I f I \text {. }
$$

Sparrow, Winter, 26, 32.

sparverius, Falco, $27,103$.

Spatula clypeata, 73,192 .

Speckled Owl, 27 .

Speckled Woodpecker, 26, 27.

spectabilis, Anas, 28 .

spectabilis, Somateria, $18 q$.

Splıyrapicus varius, $44,1 / 3$.

Spinus pinus, 47,136 .

Spizella nonticola, $32, \quad 1, f 2$.

Spizella pusilla, $39,41,1 / 72$.

Spizella socialis, $32,41,1.72$.

sponsa, Aix, 28, 73 .

sponsa, Anas, 28.

Spotted Sandpiper, go.

Sprigtailed inuck, 28.

Spring Bird, 32 .

spurius, Icterus, 38,191 .

Squatarola squatarola, 29, $9 I$.

squatarola, Squatarola, 29, $9 /$.

Squirrel, Canadiau Red, 47.

Squirrel, Gray, 43.

Squirrel, Sonthern Flying, 42.

Squirrel, Striped, 52 .

Steganopus tricolor, 85 .

stellaris, Cistothorus, $17 \%$.

Stercorarius parasiticus, 66 .

Sterna antillaru11, $29,1 S S$.

Sterua caspia, ISS.

Stertua dougalli, 68 .

Sterna fuliginosa, 68 .

Sterna hirundo, 29, 67.

Sterna minuta, 29.

Stilt, Black-1lecked, rgo.

Stilt Sandpiper, S6, 192.

Stork, 29.

strepera, Anas, 28.

strepera, Chaulelasmus, $I S 9$.

striata, Dendroica, 47, 49, 57, 163 .

Striped Squirre1, 52 .

Strix aluco, 27.

Strix bubo, 33 .

Strix nyctea, 27 .

Strix passerina, 27.

Sturnella magna, 31, 39, $/ 30$.

subbuteo, Falco, 33 .

subis, Hirundo, 32 .

subis, Progne, $32,54,1+7$.

subruficollis, Tryngites, 9o, 192.

subvirgatus, Amulodramus c., $I . f J$.

Sulá bassana, 29, 69 .

Summer Tanager, 1.77 .

Surf Scoter, 76 .
Surnia ulula caparoch, $108,193$.

swainsonii, Hylociclsla $1 ., 44,18_{3}$.

Swallow, frank, 32, 1.79.

Swallow, Barn, 32, 1.78 .

Swallow, Clinuncy, 32.

Swallow, Cliff, r.js.

Swallow, Tree, 1.19 .

Swallow Woodpecker, 27.

Swallow-tailed Kite, 96.

Swamp Spartow, 43, 1.15 .

Swal1, 27.

Swall Goose, 28.

Swan, Trumpeter, $7 s$.

Swan, Whistling, $78,192$.

Swift, Chimney, $1 / 7$.

sylvatica, Nyssil, 42.

Symphemia semipalmata, 190.

Syrnimm nebulosin, 27, 105 .

\section{T}

Tachycineta bicolor, 1.79 .

Tamias s. lysteri, 52 .

Tanager, Scarlet, 41, 54, 56, 177 .

Tanager, Summer, $r .7$.

Tauagra rubra, 32 .

Teal, Blue-winged, $28,73$.

Teal, Green-winged, 28, 72 .

Tee-arr, 29.

Tennessee WTarblur, 47, 56, 158 .

Tern, Black, $6 S$.

Tern, Caspian, 188 .

Term, Common, 67 .

Tern, Least, ISS.

Tern, Roseate, 68.

Teru, Sooty, $6 S$.

Tetrao narilandicus, 30.

Tetrao virginiauns, 30 .

Thamnophis saurita, 43 .

Thrasher, $3 \mathrm{I}$.

Thrasher, Brown, 39, 4I, 172 .

Thrush, 3 I.

Thrush, Bicknell's, $47,49,8 \Omega$.

Thrush, Gray-cheeked, $15 \%$.

Thrusli, Hermit, $40,43,45, r 8 \%$.

Tlirush, Olive-backed, $44,47, I S_{3}$.

Thrush, Wilson's, $/ S O$.

Tlirush, llood, 39, 40, 179.

Thryomanes bewickii, 173 .

Thryothorus ludovicianus, $38,172$.

tigrina, Dendroica, $47,159$.

Titmouse, Blue, 32.

Titmouse, Crested, 26, 32 .

Toad, 46.

togata, Bonasa u., $30,40,49,92$. 
Tomtcet. 32 .

Tomtect, Tellow-rumped, 32. Topogralphy, 36 . torda, Alca, 33.198 .

Tortoise, Box, 43 .

'Tortoise, Painted, 43.

Tortoise. Yellow-spotted, 43.

'Totanus flavipes, SS.

Totanus melanolcucus, ss.

totanus, Sicolopax, 29.

Towlite, $1, f 6$.

Toxostonia rufum, 31, 39, 41, 172 .

T'ransition Zone, $3^{S}$.

transitionalis, lepus f., 43.

Tree Sparrow, $1 / 2$.

Tree Swallow, 1.19 .

tricolor, Steganopus, $\mathcal{S}_{5}$.

tridactyla, Rissa, 66.

Yringa a. pacifica, 87 .

Tringa arenaria, 29.

Iringa bairlii, $\mathbf{S 6 .}$

Tringa canutus, 190.

'linga fulicaria, 29.

iringa fuscicollis, $\$ 6$.

'Tringa juterpres, 29.

Tringa maculata, $29,86$.

Iringa moritins, 190 .

'lringa minutilla, $S_{7}$.

'Tringa nuorinella, 29.

tristis, Astragaliums, 32,136 .

tristis, Fringilla, 32 .

Troclilus crilubris, $27, I / S$.

troclilus, Motacilla, 32 .

Truglodyte's atelon, 32, 11, 173 .

"I'rumpeter Swan, -5 '.

'I'rygites subruficollis, gi), 102.

'iujelo, \$2.

I'trolus migratorias, 31 .

'inrdus orplieus, 31 .

'Turlus rufus, 31 .

'lurkey V'ulture, 06.

'Turkey, Wilk, 30, f1, 9.7.

'Inrustonce, 600.

'Iurtle I)ove, 31.

'y'1n] and clius ancricanus, 187 .

tyranutus, lámius, 27.

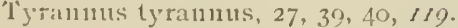

tyranulus, I'yrimutus, 27, 39, 40, $1 / 9$.

\section{U}

Ipper Austral \%one, 38.

T'ria lomvia, $33,63$.

Lirsus antericantus, 47.

usne:ce, Compsotlilypis a., 158.

\section{V}

varial, MIniotilta, 156

variegata, Nyminlica, 45.

varius, Spliyrapicus, $4.4,113$.

relox, Accipiter, 97.

vermivorus, Ilelmitherus, 156.

Vesper Sparrow, $39,41,135$.

vespertinus, Coccothraustes, $132,193$.

vigorsii, Dendroica, 41, 166.

villosus, 1)ryobates, $27,43,44,47$, $1 / 0$.

villosus, P'icus, 27.

Violit blamial, 46.

virens, Contopus, 120 .

virens, I endroica, 43,165 .

virens, Icturia, $I 70$.

Vireo bellii, 156 .

Vireo flavif rons, 41,155 .

Vireo gilvus, $15 \%$.

Vireo noveboracensis, 38, 156.

Virco olivacens, 32,152 .

Vireo plriladelplicus, 153

Vireo solitarius, $43,44,155$.

Vireo, Bell's, 156 .

Virco, Blue-lieaded, $43,44,45,155$.

Viree, Philadelphia, 153 .

Vireo, Rect-cyed, 152.

Vireo, Warbling, $15 \%$.

Vireo, White-eyed, 38,156 .

- Vireo, Yellow-throuted, -11, 155.

virescens, Ardea, 29, 41, $8 \%$

Virginial Rail, $\delta_{3}$.

virginianus, $13 \mathrm{ub}(), 33,807$.

virginianus, Colinus, 30, 41, 92.

virsiniatulus, Chordeiles, $33,40,1 / 6$.

virginianus, I.epus a., 47, 52.

virginiantus, l'artus, 32.

virginianus, Rallus, 83 .

viruinianus. 'lctrao, 30 .

visoa, Putorius, 17.

vocifera, digitlitis, $24,91,192$.

vociferus, Antrostonums, $33,40,1 / 6$.

vociferus, Clas rudrius, 29.

Vole, Rock, 47.

volueclla, Sciuropterus, 43.

Vulture, 'lurkey', go.

\section{W}

Warbler, Bay-breasted, 45, 57, 162 .

W:abler, Black and White, 156.

Warbler, Blackburmian, 44, 45, 165 .

Warbler, lilack-1) $11,47,49,57,163$.

Watrbler, Black-tharoited Blue, f(), 4.1. $45,1(x)$. 
Warbler, Black-tliroated Crecen, 43.1 Wild Goose, 28. 165.

Warbler, Cánalian, 4h, I7ィ.

Narbler, Cape May, 17, 57, 159.

Warbler, Clucstulut-sided, 39, 162.

Warbler, Connecticut, $165^{3}$.

Warlbler, Golde11-willeced, 12, 157, 193.

Warbler, Magruolia, fo, 44, 45, $16 \%$.

II'arbler, Mourning, 40, 44, 57, 169.

Warbler, Myrtle, 45, 47, 49, 5.5, 57 , 160 .

IVarbler, Nasliville, 13,47,49, 157.

IVarbler, Nortleril I'arula, 158 .

II:arbler, Orange-crowuled, 157.

V'arbler, l'alm, i66.

Viarbler, Pint, 41, 166.

Warbler, Prairic, $12,167$.

Warbler, Tennessec, $49,57,158$.

IV'abler, IVilson's, $47,170$.

IVarbler, Nornlecting, 156.

IVarbler, Yellow, 40, 5., 159.

Warbler, Yellow Pali1, 167.

Virbling Vireo, 15\%,

IVater Heir, 29.

IVater Slirew, 47.

Water-Thrush, $11,169$.

Watcr-Thrush, I,ouisiana, $16 \mathrm{~S}$.

IVater IVitcli, 29.

Waxwing. Bolicinian, 150.

TIaxwing, Cerlar, 150 .

VIease1, 1,ittle I3row11, 52.

Western Semipalmitel Sindipiper. 100.

Whip-poor-will, 33, fr, \&/6.

Wlistler, $2 \mathrm{~S}$.

IV'bistling Swwan, $75,102$.

White Back IVoolpectier, 27.

IVhite-breasted Nutliatch. 41, 176.

IVhite-crowned Sparrow, $1 . / 1$.

IVhite-eyed Virco, $38,156$.

White Hear Coot, 28.

Wlite Goose, 28.

White Gul1, 29.

Wlite Gyrfalco11, IO2.

Wlite II'ron, 29.

W'lite Oak, 41, 42.

IVlite Ow1, 27.

White-rumped Sandpiper, 86.

W'lite-tail II oodpecker, 27.

White-throated Sparrow, 40, 47, 49, $51,1 . f r$.

White-winged Crossbill, 47, 49, 135.

II hite-winged Scoter, 76 .

Widgeon, $2 \mathrm{~S}$.

IVidgeon, American, 72 .

IVild Pigcon, 31.

Wild Tiurkey, 30, 4 , 9..

11 illet, 190 .

IIilsonia candensis, $4.4,17 \%$.

Wilsonia pusilla, 47, 170 .

wilsonianus, Asio, 10.1 .

Viison's l'etrel, 60.

IVilson's I'lalarope, $\$ 5$.

Wilson's Snipe, \&5.

Wilson's 'Thrush, Ifo.

Wilson's Warbler, 47, $/ 7 \%$.

Winter Sparrow, 26, 32 .

Witcli, Water", 29.

Vinter IIren, 44, 47, 173.

Wood Duck, 28, 73.

IVood Pewee, 120 .

IVood Snipe, 29.

Wood Thrush. 39, 40, 179.

Woodcliuck, 52 .

IToodcock, 29 .

Wroodcock, An1wican, \$5.

Woodland Caribou, 48 .

VToodland Jumping Molise, 47.

Wroodpecker, Anerican T'lirec-toed, $47, \quad 112$.

Woodpecker, Arctic 'Fbreetocd, 47, 111 .

Wroodpecker, Carolina, 26.

Woodpecker, Downy, 54, $1 / 1$.

Woodpecker, folder1-winged, 54 .

IVoorlpecker, Gruat Red-crested, 27.

IToolpeckur, Hairy, 43,44, 47, 1/6.

Woodpecker, Nortlicris Pileated, 44 , 11. .

Woolpecker, Red He'ad, 27.

Woodpeckur, Red-licarled, 1/5, 193.

Woodjecker, Speckled, 26, 27.

Woodpecker, Swallow, 27.

Woodpecker, Wlite Back, 27.

Wroodpecker, Wlite 'Tail, 27.

Woolpecker, Nooly IBack, 27.

Wooly Back Woodpecker, 27.

Virm-eating Warbler, 156.

Wren, Bewick's, 173 .

IVren, Carolina, 38,172 .

IVren, Crested, 32.

IVre1, House, 41, 173 .

IV'ren, Ruby-crowned, 54.

Wren, Sliort-billed Marsl1, $17 . \%$

Vren, Wister, $44,47,173$.

\section{Y}

Yellow Palm Warloler, 167.

Yellow Pond I,ily, 46. 
Yellow Rail, IS\%.

Vellow IVarbler, 42, 54, 159.

Yellowbird, 32,54 .

Yellow-bellied Flycatcher, 47, 121 .

Fellow-bellied Sapsucker, $4.45,1 / 3$.

Yellow-billerl Cuckoo, rog, 193.

Yellow-breasted Cliat, 170 .

Yellow Crown, 32.

Yellow-legs, $\delta 8$.

Yellow-legs, fireater, $s S$.

Yellow-rumped 'Tountect, 32.

Yellow-spotted I'ortoise, 43.

Yellow-throat, Northeru, 170 .
Yellow-throated Vireo, 4I, 155.

Z

Zamelolia ludoviciana, 1.76 .

Zenaidura mactoura, 95 .

Zone, Arctic-Alpine, 49.

Zone, Hudsonian, $4 \mathrm{~S}$.

Zone, 'Transition, 38 .

Zone, Upper Austral, $3^{8}$.

Zonotrichia albicollis, 40, 47, 49, 51, IfI.

Zonotrichia leucophrys, $I, f$. 





AMNH LIBRARY 